FACULDADE DE ARQUITETURA E URBANISMO

UNIVERSIDADE DE SÃO PAULO

HISTÓRIA E FUNDAMENTOS DA ARQUITETURA E DO URBANISMO

RAFAEL URANO FRAJNDLICH

\title{
TAFURI
}

\section{TEMPO DA CIDADE LONGÍNQUA}


FACULDADE DE ARQUITETURA E URBANISMO

UNIVERSIDADE DE SÃO PAULO

HISTÓRIA E FUNDAMENTOS DA ARQUITETURA E DO URBANISMO

RAFAEL URANO FRAJNDLICH

\section{TAFURI}

\section{TEMPO DA CIDADE LONGÍNQUA}

Tese apresentada à Faculdade de Arquitetura e Urbanismo da Universidade de São Paulo para obtenção do título de Doutor em Arquitetura e Urbanismo na área de concentração História e Fundamentos da Arquitetura e do Urbanismo

Orientador: Prof. Dr. Mario Henrique D’Agostino

São Paulo

Março de 2014 
Autorizo a reprodução e divulgação total ou parcial desse trabalho, por qualquer meio convencional ou eletrônico, para fins de estudo e pesquisa, desde que citada a fonte.

rafael.urano@usp.br

F812t Frajndlich, Rafael Urano

F812t Tafuri: tempo da cidade longínqua / Rafael Urano Frajndlich. --São Paulo, 2014. 199 p. : il.

Tese (Doutorado - Área de Concentração: História e Fundamentos da Arquitetura e do Urbanismo) - FAUUŚP.

Orientador: Mario Henrique D’Agostino

1.História da arquitetura 2. História da arte 3.Tempo (Filosofia) 4.Italianos 5.Humanismo 6.Tafuri, Manfredo, 1935-1994 I.Título

CDU 72.03 
RAFAEL URANO FRAJNDLICH

TAFURI. TEMPO DA CIDADE LONGÍNQUA.

Tese apresentada à Faculdade de Arquitetura e Urbanismo da Universidade de São Paulo para obtenção do título de Doutor em Arquitetura e Urbanismo, Area de Concentração História e Fundamentos da Arquitetura e do Urbanismo

Aprovado em:

BANCA EXAMINADORA:

Prof. Dr.

Instituição:

Julgamento

Assinatura:

Prof. Dr.

Instituição:

Julgamento

Assinatura:

Prof. Dr.

Instituição:

Julgamento

Assinatura:

Prof. Dr.

Julgamento

Instituição:

Assinatura:

Prof. Dr.

Julgamento

Instituição:

Assinatura: 


\section{Resumo}

A obra do historiador da arquitetura Manfredo Tafuri (1935-1994) mantém grande pertinência nos debates contemporâneos. Sua contribuição é caracterizada pelo rigor filológico de suas pesquisas, pela leitura crítica das utopias das vanguardas e sobretudo pelo trânsito intenso de suas análises por outras disciplinas das ciências humanas, como a filosofia, a psicologia e a sociologia.

Em seus textos, o autor ladeou o Renascimento e a atualidade de diferentes modos para tecer suas argumentações, através de articulações de noções de tempo. o tempo, na prosa de Tafuri, é um objeto de estudo em si, e remonta às raízes de seu trabalho nos debates filosóficos italianos.

A tese se aprofunda nesse aspecto do historiador, na determinação feita entre períodos históricos, dando ênfase ao modo como Tafuri entendia a temporalidade. Toma-se como texto de base a conferência As formas do tempo (1993), onde podemos encontrar uma síntese de suas considerações sobre o assunto, relacionando-a com os textos mais ensaísticos sobre história assinados pelo autor, que formam o corpus desta pesquisa: Teorias e história da arquitetura (1968), Projeto e utopia (1973) e Machine et memoir: a cidade na obra de Le Corbusier (1979).

Estudar-se-á este núcleo considerando a hipótese de que a complexidade da obra de Tafuri reside no entremeio de tempos. Espera-se com este recorte destacar a atualidade das considerações críticas do autor sobre a arquitetura, demonstrar a interlocução de seus escritos com os debates filosóficos italianos de sua época, bem como aprofundar em alguns aspectos a interdisciplinaridade de sua teoria.

Palavras chave: História da arquitetura, História da arte, Tempo (filosofia), Italianos, Humanismo. 


\section{Abstract}

The work of Manfredo Tafuri (1935-1994) remains important for the History of Architecture.

His contribuition is often summarized in the filological accent of his research subjects, the critical approach of contemporary trends in architecture and most of all for the interdisciplinarity of his writings, leaning towards other fields of humanities such as philosophy, psicology and sociology.

In the overall of his work, the author established connections between Renaissance and Contemporary in different ways to make a point in his essays. The ways he framed different periods of history concerned a specific transit between notions of temporality. In Tafuri's work, time appears as a subject itself and denotes its philosphical origins in the political trends of Italy.

This thesis seeks to shed light on one specific aspect of the work of Tafuri. It will work with his most ensaistic works regarding time: The forms of time: Venice and the Renaissance (1993) and Machine et memoir: The city in the work of Le Corbusier (1979). Along with these two articles, we will focus on two seminal books signed by the author: Theories and history of architecture (1968) and Architecture and utopia (1973).

Through the study of the temporality in the work of Tafuri, we expect to broaden the understanding of his contribution, shedding light to the pertinence of his critical opinions on architecture, to the persistent dialogue his work with philosophical trends in Italy, and to give a better overall understanding of the interdisciplinary approach of his theory.

Keywords: History of Architecture, History of Art, Time (Philosophy), Italians, Humanism. 


\section{Agradecimentos}

Este trabalho não existiria sem a colaboração de diversos interlocutores.

Agradeço ao Professor Mário Henrique “Maique” D’Agostino, pela orientação rigorosa e precisa. As melhores linhas do texto a seguir são devido ao seu aconselhamento. As piores, por desatenção minha às suas recomendações.

Agradeço aos docentes das disciplinas cursadas: Agnaldo Farias, Vladimir Safatle, Ricardo Marques de Azevedo, Ricardo Fabbrini, Sandra Vicchietti e Maurício Santana Dias.

Além destes, ajudaram os professores José Lira, Fernanda Fernandes, Marta Dora Grostein, José Eduardo Lefévre, Mônica Junqueira, Hugo Segawa, Vera Pallamin, Joubert José Lancha, Regina Meyer, Álvaro Puntoni, Sophia da Silva Telles, Massimo Canevacci e Lilian Santiago-Ramos.

Devo também agradecimentos aos professores da banca de qualificação de doutorado: Olgária Matos e Adalberto Retto Júnior.

Obrigado ao IUAV, por ter aberto suas instalações, e à Fondazione Querini Stampalia, em Veneza. Em Roma, agradeço à Fondazione Bruno Zevi.

Agradeço ao Marco Pogacnik, meu supervisor de pesquisa na cidade dos canais, cuja provocativa passagem pela tese rendeu tantas modificações em seu projeto geral, que parece que o professor esteve presente durante todo o processo.

Agradeço muitíssimo aos professores entrevistados, protagonistas desta tese: Francesco Dal Co, Marco De Michelis, Giorgio Ciucci, Manuela Morresi, Marco Biraghi, Jean Louis-Cohen, Philippe Duboÿ e Giorgio Piccinato.

Ainda na península, agradeço aos contatos locais, Lilian Nakashima e Massimo Carmassi, pela interlocução geral com o IUAV, e ao Daniele Pisani, amigo e colega de várias iniciativas. 
Agradeço à Debora Antonini, que abriu seus arquivos de aulas transcritas do IUAV, além das tantas conversas sobre Manfredo Tafuri.

Obrigado a Luca Scappin, que catalogou por conta própria muitas das aulas ministradas por Tafuri no IUAV. Pessoa-chave na tese, devo a ele muito da documentação que apresento.

Obrigado a Federico Rosa, filólogo de Tafuri, por ter gentilmente cedido a documentação de sua Tesi di laurea, contendo textos, entrevistas e registros de jornais referentes à carreira do autor romano.

Agradeço à Maria Vigevani, que me ensinou italiano em um muito curto intervalo de tempo.

Tive muitos colegas que acompanharam o processo, seja lendo os textos, seja ouvindo as idas e vindas de um trabalho de realização nada linear. Um agradecimento a todos esses, não só pela disposição, mas sobretudo pela paciência: Alexandre Benoit, Guilherme Pianca, Ana Carolina Gimenez, Angela Rodrigues, Clévio Rabelo, Patrícia Osses, Marianna Boghosian, Diego Matos, Sabrina Fontenele, Matteo Cremasco, Graziela Nivoloni, Júlia da Luz, Milene Cara, Pedro Saito, Lívia Lazaneo, Gabriel Pedrosa, Pedro Veloso, Marco Massari, Larissa Rebello, Lilian SantiagoRamos, Luís Felipe Abbud, Milene Cara, Milena D’Ayala, Rodrigo “Digão” Mendes, Beatriz Rufino, Laura Sobral, Juliana Junqueira, Miguel del Castillo, Danilo Hideki Abe, Guilherme Wisnik, Carolina Tonetti, Celso Reeks, Paula Dedecca e João Yamamoto.

Um agradecimento especial à Elisa Klüger, leitora de cada rascunho, parceira de biblioteca e de incontáveis chás, além de ter sido o meu contato em Paris durante a pesquisa.

Agradeço aos arquitetos do "23 Sul Arquitetura”: André Sant'Ana, Lucas Girard, Gaú Manzi, Tiago Oakley, Moreno Zaidan Garcia, Luís Pompeo Martins, Ivo Magaldi e Luiz Florence.

Agradeço aos funcionários dedicados da Biblioteca da Faculdade de Arquitetura e Urbanismo da USP, pelo auxílio e pela gestão engendrada por Dina Uliana e Eliana Marques de Azevedo e pela dedicação de Rejane Alves e Ana Paula Lingner. 
Agradeço aos meus pais, Elita Urano e Roberto Frajndlich, e seus companheiros Humberto G. Riella e Vivianne Schunk.

Finalmente, agradeço à minha esposa, Lívia Perozim, pela sua compreensão e carinho durante a conclusão deste trabalho.

Esta tese foi realizada com o apoio da FAPESP - Fundação de Amparo à Pesquisa do Estado de São Paulo. 
Para Livia 


\section{TAFURI}

TEMPO DA CIDADE LONGÍNQUA

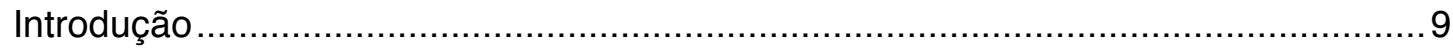

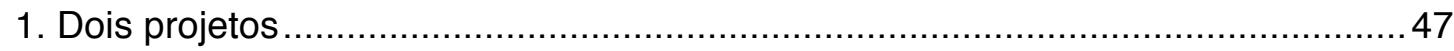

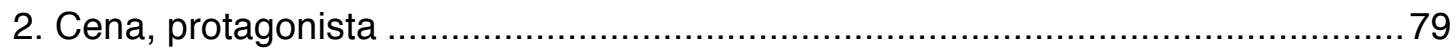

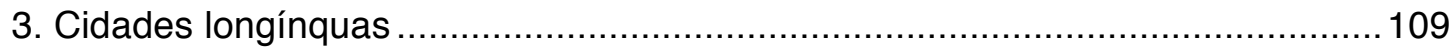

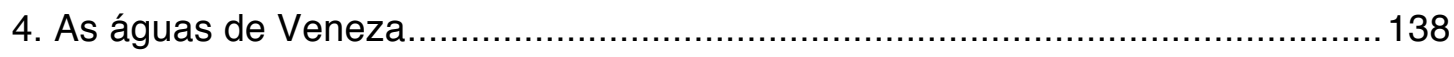

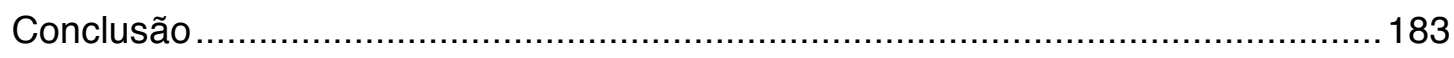

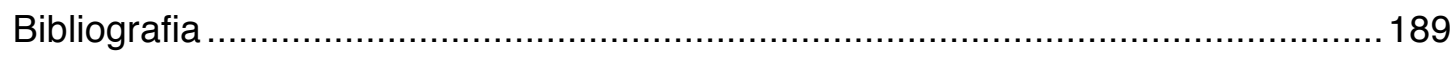

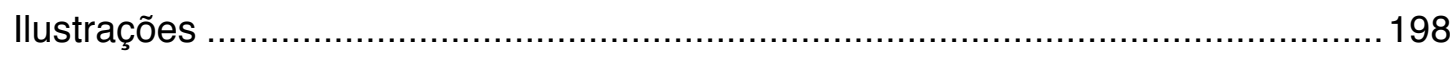


No meio do caminho tinha uma pedra tinha uma pedra no meio do caminho tinha uma pedra

no meio do caminho tinha uma pedra.

Nunca me esquecerei desse acontecimento na vida de minhas retinas tão fatigadas.

Nunca me esquecerei que no meio do caminho tinha uma pedra

tinha uma pedra no meio do caminho no meio do caminho tinha uma pedra.

Carlos Drummond de Andrade

No meio do caminho 


\section{Introdução}

Entre 1959 e 1994 escreveu Manfredo Tafuri. Sua obra cobriu um arco amplo de períodos históricos, por meio de ensaios, livros, atas de conferência e transcrições de aulas que ainda não estão completamente disponíveis.

Durante seus anos de formação, lutou como estudante contra os quadros docentes das faculdades romanas que, após a guerra, mantinham-se ligados ao fascismo. Já graduado, sua produção intelectual partiu ao confronto da raiz historiográfica desenvolvida pelos seus mestres e colegas de alinhamento político, para dar novas bases à história da arquitetura, enquanto ainda conciliava suas atividades de pesquisador com a rotina em um escritório de projetos - trabalho que abandonaria no primeiro lustro dos anos sessenta.

Em 1968, o autor romano assume a cátedra de história no Instituto Universitário de Arquitetura de Veneza (IUAV). Consolida sua contribuição para a história da arquitetura contemporânea: forma equipes de documentação, amplia seus campos de análise: em pesquisas tanto do contemporâneo quanto do humanismo, levou os limites dos estudos para além dos prédios construídos e das publicações, tornam-se importantes as atas entre clientes e arquitetos, os esboços, os croquis, as notas ao pé das plantas, a reconstituição do tecido original dos períodos estudados.

Ultrapassou os limites da península e alcançou reconhecimento internacional quando publicou, em 1973, "Projeto e utopia”, um itinerário da arquitetura contemporânea na qual as vanguardas são lidas como detentoras de um papel complementar no amplo processo de reorganização capitalista, como formadora de ideologias de planificação global e reordenada das metrópoles. A obra teve rápido impacto na Europa e Estados Unidos, o que fez com que o trabalho ganhasse interlocução com os historiadores americanos do período. Revistas como Oppositions, 
debates publicados como "Arquitetura, crítica e ideologia", comprovam como as pesquisas de história nos EUA tiveram sua inteligência informada por Tafuri.

Nos anos oitenta, como professor reconhecido, reafirmou sua imagem de provocador ao relegar para o segundo plano os debates contemporâneos. A partir de 1981, privilegiou a arquitetura italiana e seus desdobramentos anteriores ao século XVIII. Apesar deste foco mais específico de pesquisa, o fulcro de seus estudos não se torna menos amplo: Veneza e sua posição entre Ocidente e Oriente, a Roma dos Medici, as obras de Raffaello Sanzio, Giulio Romano, Leon Battista Alberti, são todas estudadas nos cursos monográficos do autor, formato que seria o seu modo de pesquisa até o fim de sua vida, em 1994.

Sua prática é lembrada nestes termos: um lado institucional, como criador de uma leitura crítica de arquitetura, baseada na formação de uma escola filológica e profissional de história, e outro como contestador, incitador de uma busca das contradições de toda postulação, das opiniões conciliatórias e dos discursos sedimentados.

Passados vinte anos desde sua morte, no entanto, permanece uma série de dúvidas acerca da profundidade dos textos do autor. Malgrado Tafuri tenha uma bem estabelecida posição dentro do quadro geral de intelectuais que versaram sobre arquitetura no século XX, ainda há muita margem para novas leituras de sua obra.

Diante disso, propõe-se um recorte estratégico, no qual o estudo de Tafuri parta de uma categoria incomum no primeiro plano de seus textos, mas presente ao longo de toda a sua trajetória: estudar como o autor entendia, em diferentes momentos de sua carreira, a relação política existente entre os objetos de estudo e as possibilidades de transformação do real, a formulação de como o tempo passado poderia ter força de articulação do presente.

Tafuri, um historiador de arquitetura e de cidades, tinha no seu texto de lidar com diferentes formas misturadas entre ruas, praças e monumentos. $\mathrm{Na}$ sua prosa, tem-se uma elaboração análoga: dos seus textos de juventude até as últimas conferências e aulas magnas, Renascimento e contemporâneo, vanguardas e barroco, collages e maneirismos são ladeados, entremeados e contrastados.

Igualmente, perpassando desde a juventude até a maturidade, aparece a persistência de uma predileção pelas obras de arquitetura que contêm uma subversão 
temporal - a capacidade de intercalar o passado e o presente, a teleologia e o nostálgico, a ruína e a transformação. "Nada é dado por passado", escreveu Tafuri em 1992. "O tempo da história é, por constituição, híbrido". ${ }^{1}$

Os sincronismos entre diferentes períodos históricos é um tema sempre profícuo a quem se ocupe do corpus teórico de Tafuri. Neste estudo de diferentes épocas, é preciso ter em mente que nas construções históricas de Tafuri o que está constantemente sendo fruto de compactação, separação e justaposição não são tanto as histórias dos edifícios, mas uma própria construção sobre o tempo: em alguns de seus textos, o moderno e o contemporâneo serão vistos como continuidade quase simultânea, ou um parecerá a lente pela qual se lerá o outro. Em alguns momentos a ausência total de um destes termos será pretexto para colocá-lo nas entrelinhas do outro. A tese se aprofunda nesse aspecto do historiador, na determinação feita entre períodos históricos, com ênfase em como Tafuri entendia a temporalidade.

Para tanto, será preciso retornar aos seus principais textos, bem como se aprofundar em artigos pontuais, nos quais a questão da temporalidade é tratada de modo direto. Entre obras seminais e ensaios isolados, tem-se como denominador comum o fato de carregarem, na sua prosa, testemunhos da verve ensaística de Tafuri, nas quais o rigor filológico atribuído ao professor contrasta com interpretações menos precisas, que denotam interesses mais estratégicos do que uma construção histórica estritamente acadêmica apresenta.

O ensaísmo é o mais revelador sintoma de como foi engajada politicamente a obra de Tafuri: nenhum de seus escritos escapa da interlocução com as correntes intelectuais de esquerda em voga na Itália e na Europa. Nos anos sessenta, dialogava, entre outros, com Della Volpe, Paci e Bettini. Nos anos setenta, a década "radical” em que publicou "Projeto e utopia", formulou, sempre através da história da arquitetura, debates com Tronti, Cacciari, Asor Rosa e Esposito. Na década de oitenta, sua guinada ao Renascimento coincidiu com uma argumentação com Marramao, Agamben (timidamente) e com os textos de maturidade de Cacciari.

Nesse sentido, busca-se, além de esmiuçar uma matriz filosófica cara para a contribuição histórica de Tafuri, demonstrar os meios pelos quais sua atuação

${ }^{1}$ TAFURI, Manfredo. Ricerca del rinascimento. Principi, città, architetti. Turim: Einaudi, 1992, p. 24. Grifo de Tafuri. 
profissional dentro do IUAV, ainda que afastada de filiações partidárias ou de engajamentos em questões contingenciais, tinha uma clara e preponderante intenção política.

Ademais, nesses textos ensaísticos nos quais a temporalidade se sobressai, temse acesso a uma face de Tafuri distinta daquela que comumente se the atribui na historiografia em voga: diferentemente de um crítico mordaz de toda e qualquer pretensão positiva, vemos que em meio à melancolia de seus escritos existe uma centelha discreta, de quem sente no estudo da história da arquitetura o auspício de algum poder de transformação.

Toma-se como ponto de partida um artigo publicado na revista norteamericana Assemblage, de 1995, assinado por Hélène Lipstadt e Harvey Mendelsohn: "Filosofia, história e autobiografia: Manfredo Tafuri e a 'lição insuperada' de Le Corbusier". Defende-se no ensaio o argumento de que Le Corbusier é um protagonista não declarado na obra de Tafuri. "Se deve existir uma história de qualquer parte da obra de Tafuri, Le Corbusier representa um excelente ponto de partida, pois quando o 'moderno método filológico' é aplicado a este personagem, um silêncio eloquente é audível.”2

Em "Teorias e história da arquitetura”, ele aparece como professor involuntário de uma "lição insuperada" em urbanismo, ao falar das relações entre centro histórico e novas postulações urbanísticas. Em "Projeto e utopia”, seu projeto para a baía de Argel é lido como "a hipótese teórica mais elevada da urbanística moderna, ainda insuperada tanto no nível ideológico como no formal,"3 sendo nos anos trinta o grande ponto de virada para a crise das vanguardas. Vendo os auges de ataques críticos aos arquitetos de diversos períodos, Lipstadt e Mendelsohn perceberam que Tafuri colocava Le Corbusier sempre como um como um protagonista em seus textos.Os autores apontam para um ensaio longo de Tafuri escrito nos anos oitenta, "Machine et memoir: a cidade na obra de Le Corbusier". Nele, o suíço é colocado como um antimoderno, ou um modernista melancólico. Entre "Teorias e história" e "Machine et memoir" existe um arco de quinze anos que mostra como Tafuri muda suas opiniões sobre o potencial

\footnotetext{
${ }^{2}$ LIPSTADT, HELEN e MENDELSOHN, HARVEY. "Philosophy, History and Autobiography: Manfredo Tafuri and the unsurpassed lesson of Le Corbusier", In: Assemblage, 22, 1994, p. 60.

${ }_{3}$ TAFURI, Manfredo. Progetto e utopia, architettura e sviluppo capitalistico. Bari: Laterza, 1973. Tradução para o português: Projecto e utopia, arquitetura e desenvolvimento do capitalismo. Lisboa e São Paulo: Estampa e Martins Fontes, 1985, p. 87.
} 
transformador e ideológico das vanguardas, sem entretanto descredenciar Le Corbusier como um arquiteto central da contemporaneidade. Lipstadt e Mendelsohn fizeram uma breve investigação filológica do projeto do arquiteto em Chandigarh, e viram como a Main ouverte aparecia em outras obras, como no topo de uma grande usina. Mostraram como o próprio Le Corbusier mantinha certo progressismo maquinista na sua arquitetura feita na Índia - para além de qualquer melancolia atribuída por Tafuri. Expôs-se um ponto cego no rigor filológico do autor romano, que depositou em Le Corbusier uma série de expectativas acerca do contemporâneo estranhas às intenções do arquiteto, analogamente ao que fez a geração anterior, como Argan com Gropius, ou Zevi com Frank Lloyd Wright.

É certo que a autoridade do artigo de Lipstadt e Mendelsohn fica menor nas conclusões, ao fazer uma análise apressada das filiações filosóficas de Tafuri nos seus últimos anos de carreira. Ademais, o trabalho tem um curto levantamento filológico, atribuindo traços autobiográficos a "Teorias e história” que não se sustentam, como, por exemplo, uma certa nostalgia de Veneza.

Entretanto, mesmo diante de estudos mais recentes e precisos, o artigo de Lipstadt e Mendelsohn permanece ainda uma "letra viva" nas suas considerações sobre Tafuri e o seu interesse em Le Corbusier. Apesar de pouco divulgado, o texto deveria ser considerado referencial no campo de leituras sobre o autor romano. Possui uma boa seleção de corpus, centrando-se em "Teorias e história" e "Machine et memoir", escapando do foco usual dos críticos, que sempre partem do onipresente "Projeto e utopia”, além de mostrar novas perspectivas da obra do autor, sem fazer uma subscrição ao modo que Tafuri gostaria de ter sua contribuição interpretada.

Lipstadt e Mendelsohn poderiam ter se aprofundado na obra geral do autor, sobretudo em documentação disponível sobre suas aulas e conferências. Ali encontrariam reforços para a hipótese de que Le Corbusier era importante ao historiador romano. Já na sua juventude, em um curso ministrado em 1964-65, quando era assistente em Roma, intitulado "A arquitetura moderna à luz dos problemas atuais”, Tafuri dedica a última aula a Le Corbusier:

A obra lecorbusiana, no arco por ele percorrido, parece superar continuamente as contradiçôes e impasses que verificamos 
no curso das liçôes precedentes, não tanto superando aquelas dificuldades histórico-metodológicas, quanto evitando-as mediante impostaçôes prático-conceituais que desde o princípio resolvem os nós nos quais se apegaram as vanguardas européias. ${ }^{4}$

Sobressaem-se as leituras que Tafuri faz de Chandigarh e da Main ouverte, segundo as quais ali está a "grande lição lecorbuseriana: nela está o sinal da vontade do homem de ascender à própria autoconsciência, que é a plenitude da atividade transformadora do real e conhecimento da história, imergindo no drama histórico sem se abandonar a solipsistas divagações...."

Esse contraste que Tafuri via entre a Main ouverte, o Himalaia e a Índia com o urbanismo modernista de Chandigarh e toda a herança das vanguardas européias, acredita-se, pode ser levado a um traço mais amplo da sua obra, para além do protagonismo de Le Corbusier. Existe um aspecto marcante em seus artigos, que é o de comparar períodos históricos distantes entre si para deles tirar uma imagem comum. Essa "distância" é levada ao extremo nos textos ensaísticos do autor romano, muitas vezes sacrificando a exatidão e sucessão de correntes artísticas para formular raciocínios imprevisíveis e, do ponto de vista da construção histórica, arbitrários. A interlocução de formas diferentes na sua obra aparece por vezes com muita simultaneidade:

O espaço histórico não constrói pontes improváveis entre linguagens diversas, entre técnicas distantes entre si. Este antes explora o que tal distância exprime: sonda isto que se apresenta como um vazio, tenta fazer falar a ausência que parece preenchelo.

Uma operação que se cala nos interstícios das técnicas e linguagens, portanto. Operando nos insterstícios, o historiador não pretende suturá-los: procura fazê-los explodir, atingindo o limite das linguagens. ${ }^{6}$

\footnotetext{
${ }^{4}$ TAFURI, Manfredo. L'architettura moderna alla luce dei problemi attuali - corso di composizione architettonica II. Palermo: Facoltà di Architettura dell'Università di Palermo,. 1966-67, p. 56. Curso primeiramente ministrado em Roma, 1964.

${ }^{5}$ Idem, p. 60.

'TAFURI, Manfredo. “Il 'progetto’ storico”, In. Casabella, n. 429, 1977, p. 18.
} 
Tais construções supõem uma certa compressão do tempo. Tal aproximação, corrente nas referências do autor romano, torna-se excelente na história da arquitetura, na medida em que as cidades são o ponto de justaposição e conflito de diversos momentos históricos, correntes, edifícios, traçados. A intenção de Tafuri de criar pontes que levem ao limite as interpretações encontra assim um campo disciplinar muito afeito a tais considerações.

Sobre os usos deste seu procedimento, o historiador Jean-Louis Cohen escreveu, nos anos oitenta, apontando para a importância destas 'pontes' na própria estilística de Tafuri:

Em seu trabalho sobre arquitetura moderna, na verdade é sobre o binômio continuidade/ruptura pelo qual ele operará (...). $\grave{A}$ ideia de uma ruptura radical entre a arquitetura moderna e a tradição eclética, Tafuri e seus pesquisadores de Veneza vão opor o rastreio de uma cultura artística ancorada no clássico, em Otto Wagner, em Peter Behrens, em Adolf Loos, e nos elementos da modernidade, por vezes radicais, que os arquitetos introduzem: é assim uma imagem da recorrência de temas à origem mais antiga, mas que têm um senso novo sendo-lhe dotado, articulando as ideias e as formas da modernidade sobre uma espécie de longa duração arquitetônica. ${ }^{7}$

Tal persistência implica a subjacência a uma específica noção filosófica de tempo: a simultaneidade com que Tafuri trabalha é produto de uma interlocução construída pelo autor italiano com a temporalidade na história da arquitetura. Existia no contexto italiano um ambiente que endossava tais perspectivas. No pós-guerra, os debates intelectuais nas esquerdas italianas passavam pela discussão acerca da possibilidade de uma modificação radical, que requereria um tempo

7 COHEN, Jean-Louis. "La coupure entre architectes et intellectuels, ou les enseignements de l'italophilie." In. In Extenso, v.1, 1984, pp. 214-215. O autor demonstra como essa "longa duração" aparece até na estilística de Tafuri: "Uma das grandes formas de base deste discurso [o sistema retórico de Tafuri] que se nos permitem chamar "metafúrico" é o cruzamento. (...) As relações entre os dois fatos pode ser a casualidade, a simultaneidade, a proximidade no espaço ou outras, o importante é poder construir com o cruzamento de duas ordens às vezes um efeito explicativo surpreendente e um efeito narrativo (...)", Idem, p. 217. 
revolucionário. As referências de Tafuri, desde o princípio até o final da carreira passam por teóricos que, para além do enfrentamento de desafios historiográficos, moveram esforços para tecer uma argumentação acerca do tempo, das noções de tempo que deveriam ser subvertidas e, na terra de Gramsci e Croce, tal debate passava largamente pelas artes e pela arquitetura.

Nos anos sessenta, quando ainda conciliava as atividades de arquiteto e historiador, tem-se indícios de que Tafuri possuía já uma indagação às noções de tempo que motivavam a arquitetura: no curso em que Le Corbusier aparecia como figura central, Tafuri diz que o arquiteto suíço “parece querer recuperar não apenas uma eloquência capaz de absorver no seu ditado uma alta definição ética, nova pela sua amplitude, mas também uma dimensão figural ausente para os mestres do racionalismo: a dimensão temporal." Segundo o jovem Tafuri, essa dimensão temporal aparece sobretudo nos jogos plásticos de Chandigarh e Ronchamp, mas sobretudo na crueza dos materiais, "nas quais se acentua o aspecto sensitivo como parâmetro de leitura, torna-se tempo congelado, violência feita à percepção". ${ }^{9}$

Se Lipstadt e Mendelsohn foram sensíveis ao notar a onipresença do arquiteto suíço nos textos do historiador, acredita-se que é necessário tratá-la como sintoma do quadro geral da preocupação de Tafuri com o tempo. As aparições do suíço em "Teorias e história", "Projeto e utopia" e em muitos outros ensaios sempre trazem em si a subversão temporal - especialmente, através desse tempo estático, o tempo congelado.

Esses estudos são retomados ao longo da trajetória do autor, aparecendo pela última vez numa conferência feita em 1993, a penúltima feita pelo autor romano antes de sua morte, intitulada "A dignidade do átimo. As formas do tempo: Veneza e a modernidade", que consolida as formuações de Tafuri no assunto, costurando relações entre o presente da cidade onde lecionou toda a sua vida, Veneza, e a recusa de seus gestores, através dos séculos, de inseri-la completamente no mundo contemporâneo.

Assim como Le Corbusier e os venezianos, o próprio historiador de Roma procurou em sua obra dar diferentes matizes de pesquisa assumindo que a crítica de arquitetura é um conflito de formas, mas sobretudo de tempos. Assim, toda escolha de

${ }^{8}$ TAFURI, Manfredo. La storia dell'architettura moderna alla luce dei problemi attuali, Op. cit. p. 58.

${ }^{9}$ Idem, p. 58. 
arquitetura para a cidade é um projeto que contém não só a sua realização como uma certa vontade de cidade. Tafuri estudava não só a cidade real, dada, mas aquela que se conflitava nas suas aspirações de diferentes épocas: buscava o tempo da cidade longínqua.

Oferecer, por meio do estudo da temporalidade, um contraponto à sua noção de projeto histórico, poderá colaborar para complexificar a obra de um autor que malgrado extensa e variada é frequentemente exposta em termos menos generosos. Integrando esta nova senda de textos sobre Tafuri iniciada na década passada, essa tese visa abordar a questão pela ótica da temporalidade. Massimo Cacciari, filósofo e colega próximo de Tafuri, escreveu, na ocasião da morte do autor, que ele "podia ver o universo em um grão de areia." ${ }^{10}$ Tal idéia de compactação do todo tem grande eloquência para as nossas considerações; se a pertinência de Tafuri hoje é reconhecida, acredita-se que o estudo deste aspecto ajude a aproximar o presente a estas décadas passadas, embora recentes, e que desse conflito surjam novos modos de inteligir a sua contribuição.

A hipótese da tese, portanto, é de que a complexidade da historiografia do autor romano reside no seu entremeio de tempos, como substrato de seu labor. Estudar tal categoria é se aprofundar no próprio pensamento de Tafuri sem os vícios recorrentes que incidem nas análises de seus comentadores, que frequentemente leem sua contribuição como estritamente metodológica, política ou filológica.

A bibliografia de comentadores de Tafuri aumentou significativamente nos últimos dez anos. $\mathrm{Na}$ Itália, uma senda de textos foi publicada buscando novas matizes de seu conterrâneo. Os americanos demonstram um novo interesse em balancear aquela geração dos anos setenta e oitenta que pautou sua leitura nos textos críticos de Tafuri sobre o contemporâneo.

Esse contexto é vantajoso porque poupa o trabalho de se fazer uma apresentação das linhas-mestras do pensamento do historiador. Desde 2009 tem-se uma bem estabelecida cronologia de textos do autor disponíveis, uma parte de sua obra vem sendo publicada novamente, tanto em italiano como em outras línguas e, graças aos trabalhos de divulgação feitos por Titia Hoekstra, Federico Rosa e Andrew Leach, já foi construído um mosaico sólido da sua carreira.

\footnotetext{
${ }^{10}$ CACCIARI, Massimo. “Obituary”, “In: L'Architecture d'aujourd'bui, n. 292, 1994, p. 25.
} 
A revisão bibliográfica mostra como ainda são poucos os que pensaram a temporalidade de Tafuri como central nas suas formulações históricas. Jorge León Casero, num artigo intitulado "Aion e historiografia na obra de Manfredo Tafuri”, é o único que se ocupou diretamente da questão, tomando como principal referência a conferência do autor de 1993 - “A dignidade do átimo" - comparando-a com o texto de Cacciari, "Do início", publicado no princípio dos anos noventa. É interessante a genealogia que o filósofo espanhol tece acerca do pensamento heideggeriano de Cacciari nos anos noventa. Casero é muito convincente, nos seus argumentos, de que entre Tafuri e Cacciari houve um debate através dessas obras. Casero atribui a Tafuri a construção de uma "historiografia aiónica", que "busca determinar com a máxima precisão os momentos de extrema abertura em cada acontecimento analisado, o que equivale a esquecer tudo o que ocorreu cronologicamente depois e, expulsa toda estrutura suprahistórica, entender o futuro de qualquer acontecimento analisado enquanto impossível de prever."11

Amparando-se nos estudos de Tafuri sobre o átimo, Casero é capaz de demonstrar como o entremeio de períodos históricos é fruto de uma estruturação de Tafuri sobre a filosofia do tempo. Nesse sentido, elucida como, a partir de um dialogo com Cacciari, o autor romano conseguiu colocar novos problemas para a prosa da história da arquitetura.

Entretanto, o autor perde-se no passo seguinte de sua argumentação. Ansioso por lastrear o átimo de Tafuri em alguma escola filosófica, termina por aproxima-lo ao pensamento de Althusser e, nas conclusões, à noção de rizoma de Gilles Deleuze.

Numa obra tão eclética em suas referências como é a de Tafuri, Casero conseguiu encontrar pontos comuns entre o historiador romano e o filósofo francês, mas, tendo como pano de fundo o todo dos textos de Tafuri, tem-se um prejuízo teórico muito marcante em tentar cotejar o seu átimo apressadamente a uma determinada corrente filosófica. Como imaginar o tempo em Tafuri sem considerar, apenas para citar alguns exemplos, o instante em Benjamin? Ou mesmo o Augenblick de Heidegger, sobretudo depois de 1975, quando as esquerdas italianas tornaram ao filósofo alemão e às suas inquirições sobre o tempo? Para além desses, tem-se a

${ }^{11}$ CASERO, Jorge León. "Aion e historiografía en la obra de Manfredo Tafuri”. In: Daímon n. 56, 2012, p. 185. 
multidão de outros autores cujo tempo das transformações e vicissitudes auspiciam o instante como ponto de ruptura com a temporalidade sucessiva e ahistórica, como Garin, Bettini, Della Volpe, ou mesmo nos textos de figuras do humanismo como Alberti, Sanudo e Colonna?

Casero deseja polemizar com comentadores que, segundo sua opinião, estabelecem uma relação demasiado imediata entre a forma fragmentada das metrópoles e o âmbito "metodológico-historiográfico" do historiador. Em resumo, aqueles que querem atribuir os entremeios históricos de Tafuri como uma emulação em escrita do que acontece na arquitetura das cidades, Casero procura um outro caminho, buscando as leituras filosóficas do autor romano. Considerando Tafuri um "estudioso do marxismo", o espanhol atesta que "devemos reconhecer uma débil dependência indireta da [sua] historiografia acerca do aión ontológico." ${ }^{12}$

Os laços imediatos entre pós-estruturalismo e marxismo que Casero cria não ajudam a elucidar como esse pensamento se traduzia em intenções políticas, ou como eles sustentam toda a modificação feita por Tafuri na história da arquitetura. Traz poucos resultados, pela rápida explicação das razões pelas quais o instante é importante para Tafuri, desconsiderando as vicissitudes da trajetória do autor romano, reduzindo sua "não-metodologia" a uma questão, paradoxalmente, metodológica do fazer história.

Apesar de abrir uma margem de estudos baseada em Tafuri tomando-o como comentador de categorias filosóficas - o que ainda deve render muitas novas ideias sobre o seu legado - Casero ainda vê o aión tafuriano como uma decisão metodológica, baseada em uma suposta formação marxista. Acredita-se que o aión ou o instante e o debate sobre temporalidade que ele requer era algo que entrava em conflito com uma visão metodológica-historiográfica, e não servia para sustentá-la.

Para defender esse ponto, e permitir que se estude a temporalidade em Tafuri de modo a realmente abrir perspectivas novas, é necessário polemizar com a força e onipresença que um dos seus textos ganhou nos últimos anos como compêndio de sua contribuição à história da arquitetura: o seu "projeto histórico".

Em 1977, pouco menos de dez anos passados depois de seus textos de maior projeção, "Teorias e história da arquitetura" e "Projeto e utopia”, já tendo constituído

\footnotetext{
${ }^{12}$ Idem, p. 193.
} 
plenamente o seu Instituto de História da Arquitetura em Veneza, ao lado dos professores Francesco Dal Co, Marco de Michelis e Massimo Cacciari e seus colegas vindos de Roma, Giorgio Ciucci e Mario Manieri-Elia, Tafuri publica na Revista Casabella um texto intitulado "O projeto histórico". Tratava-se da revisão de um artigo publicado dois anos antes em uma revista de circulação mais restrita, Arte Veneta, chamado “Arquitetura e historiografia: uma proposta de método.”

O título ganhou mais impacto e procurava postular uma prática da história. Segundo o ensaio, uma intervenção direta no real deve não só se nutrir da tarefa analítica dos dados históricos, das relações entre os autores das obras e das especificidades de cada trabalho, mas deve ao mesmo tempo colocar os instrumentos de sua construção em contínuo questionamento. Para fundamentar este ponto de vista, o ensaio de Tafuri lança mão de diversos exemplos de sua carreira e reforça a sua relação entre filósofos e teóricos seminais do século XIX e XX.

No período, o autor estava no auge: suas atenções dividem-se de modo quase equivalente entre contemporaneidade e século XV e XVI. O "Projeto" tinha, na ocasião, uma clara intenção de ser referencial: chegou ao público como um depoimento crítico de Tafuri, um balanço acerca dos parâmetros de sua contribuição em andamento à história da arquitetura. Foi traduzido rapidamente para o inglês e outras línguas.

O ensaio parte de uma investigação acerca das escolhas, riscos e arbitrariedades inerentes à investigação histórica. Retomando temas provenientes de seus escritos dos anos sessenta e setenta, o autor reforça o argumento de que toda decisão do historiador incorre em uma decisão crítica, na qual dois fatores se determinam e contrapõem-se: os objetos mesmo em estudo e os instrumentos pelos quais o intelectual dele se aproxima. "O autêntico problema", escreveu Tafuri, "é como projetar uma crítica capaz de por em contínua crise a si própria colocando em crise o real."13

O artigo não tinha referências diretas à contingência, à situação da Itália do período ou maiores digressões sobre correntes no presente. Tudo indica que ali Tafuri, além de querer focar seu argumento em questões mais amplas que as da arquitetura, gostaria, sobretudo, de fazer uma obra atemporal. As conclusões são eloquentes e

\footnotetext{
${ }^{13}$ TAFURI, Manfredo. "Il 'progetto' storico", Op. cit. p. 16.
} 
propõem-se a colocar o desafio de que a "história deve estar disposta a arriscar: no limite, uma provisória 'inatualidade'."14

Voluntária ou involuntariamente, foi o que ocorreu. Após a morte de Tafuri, em 1994, a revista Casabella, lançou menos de um ano depois, uma edição em homenagem ao autor. A publicação continha uma série de depoimentos feitos por conhecedores da obra do professor, que sob a tutela do editor Vittorio Gregotti montaram um número exclusivamente ensaístico da revista, intitulado "O projeto histórico de Manfredo Tafuri”.

A proximidade de Gregotti com Tafuri, somada ao fato de que a revista Casabella foi o principal espaço de debates e artigos que contaram com a participação do autor ao longo de sua vida, deu à edição autoridade de homenagem oficial. Não só colegas que trabalharam com o historiador ao longo de todas as etapas de sua vida (esquematicamente, Asor Rosa e Giorgio Ciucci durante os anos sessenta, Jean-Louis Cohen nos anos setenta, junto de seus comentadores americanos como Joan Oackman, e Howard Burns na década de oitenta e noventa). Seus alunos escreveram depoimentos sobre suas aulas. Encerrando o número era publicada pela primeira vez a oração fúnebre feita por Massimo Cacciari no velório de seu colega.

O compêndio já possui dezoito anos e ainda se mantém referencial. Desde a morte do historiador, convencionou-se tacitamente adotar o termo-título da revista, projeto histórico, para resumir o todo da contribuição intelectual de Tafuri, como aparece na Casabella de 1994.

A escolha da revista sacramenta um lema necessário para resumir o corpus de Tafuri. Optou-se por um título utilizado por ele em uma fase importante de sua carreira, que contou com ampla difusão.

Prova dessa aceitação é que os comentadores atuais, em sua maioria, trabalham com a noção de projeto na obra de Tafuri. O historiador milanês Marco Biraghi declara que seu livro sobre o historiador, "Projeto de crise", parte da "Convicção em suma (...) de que o Projeto de crise de Manfredo Tafuri, nos termos cronológicos precisados, podem dar uma ajuda fundamental à compreensão da conjuntura

\footnotetext{
${ }^{14}$ Idem, p. 18.
} 
arquitetônica hodierna." ${ }^{15} \mathrm{O}$ crítico australiano Andrew Leach também subscreve o termo ao final de sua obra, "Escolhendo história", inferindo que "O conceito de 'projeto' é particularmente importante no trabalho de Tafuri; sua significação passa por vários campos de sua recepção. Alguns concordam que os seus leitores devam entender seu 'legado' (ou legados), mas há consenso que toda compreensão envolverá um 'projeto', mesmo que haja desacordos em matéria de detalhes." ${ }^{16}$ Até mesmo Anthony Vidler, no seu itinerário sobre historiadores contemporâneos de arquitetura, também corrobora o termo em suas análises:

Certamente em Ricerca [del Rinascimento] Tafuri parece 'alcançar' aquilo que ele tinha estabelecido como o projeto bistórico em Teorie e storia' - contrapor ao 'mito contra a história' das vanguardas (Barthes) a história contra o mito, 'resgatar a historicidade da teia do passado' onde o modernismo 'desde o principio, nos movimentos vanguardistas europeus [se apresentavam] como verdadeiros desafios à história. ${ }^{17}$

Tal noção, na medida em que sugere a existência de uma pauta objetiva feita por Tafuri, privilegia uma compreensão de seus textos a partir da coerência em detrimento das contradições. A influência de diversos autores, desde os estruturalistas nos anos sessenta até a escola francesa dos Annales nos anos oitenta, e toda gama de teóricos de diversas áreas citados por Tafuri são compreendidos, por conseguinte, como inserções convenientes numa suposta agenda de fundação de uma historiografia da arquitetura.

Pode-se dizer que da "nova onda" de comentadores de Tafuri, os que desejaram ser mais completos e de fato se tornarem referenciais ao estudo do autor, tiveram de, além de demonstrar certa segurança no todo da sua produção crítica, articular e analisar os dilemas contidos nesse trabalho. O "Projeto" forma, junto de “Teorias e história" e "Projeto e utopia", um corpus preliminar para o estudo da obra de

\footnotetext{
${ }^{15}$ BIRAGHI, Marco. Progetto di crisi, Manfredo Tafuri e la architettura contemporanea. Milão: Christan Marinotti Editori, n. 9, 2005. Grifo do autor.

${ }^{16}$ LEACH, Andrew. Choosing history: A study of Manfredo Tafuri's Theorisation of Architectural History and of Architectural History Research. Gent: Tese de doutorado, 2005, p. 249.

${ }^{17}$ VIDLER, Anthony. History of the immediate present: Inventing Architectural Modernism. Cambridge: The MIT Press, 2008, p. 171.
} 
Tafuri e é inescapável não importam os caminhos pelos quais trilhe um autor que se propôs a dar contorno à contribuição de Tafuri, especialmente porque:

Tem referencias diretas a traços presentes em toda a obra do autor: a crítica à ideologia - ou o subsequente rigor filológico ${ }^{18}$ - e um posicionamento claro acerca das tarefas do historiador em um mundo pós-vanguardas;

- $\quad$ Explicita o caráter fundamental da estilística de Tafuri, que é o trânsito entre períodos históricos. Em todos, o presente e o passado são misturados, cotejados e analisados como um compêndio de dilemas de longa duração

- É um momento de inflexão na obra do autor. "O projeto histórico" é uma carta de intenções para que Tafuri abraçasse de fato as pesquisas filológicas dentro do Instituto, enfatizando seus recortes quase exclusivamente no humanismo.

Entretanto, é de fato um 'projeto' histórico algo que está presente em todas as linhas do autor? Passados vinte anos de sua morte, a subscrição a este termo não possui, mais do que aquela 'inatualidade' salutar a que Tafuri se referia, a uma dose nociva de anacronismo?

Que sua contribuição possa ser resumida a uma só expressão - 'projeto histórico' - seria já um problema terminológico, mas o ponto mais grave reside no fato de que ele foi cunhado pelo próprio autor e, como tal, sofre a implacável pressão dos interesses em jogo durante o contexto em que foi escrito, independente do seu pretenso caráter atemporal. É preciso colocar em perspectiva histórica o artigo, considerando os diálogos em voga no período.

Em correspondência de 1977 a um de seus discípulos franceses, Philippe Duboÿ, Tafuri comenta estar retrabalhando seu artigo recém publicado:

O projeto histórico: é a introdução ao livro que estou escrevendo para a Einaudi (desde Piranesi às Cendres de

\footnotetext{
${ }^{18}$ Aqui amparo-me no argumento de Alberto Asor Rosa: "A crítica à ideologia, precede e determina a descoberta da 'filologia', faz dela não só possível, mas necessária." In: ASOR ROSA, Alberto. "Critica dell'ideologia ed esercizio storico" In: Casabella, no. 619-620, 1995, p. 32.
} 
Jefferson'): é um artigo que escrevi em oito meses - tanto tempo quanto para conceber um filho! - e no qual acredito muito. Foucault e os outros são um pretexto, obviamente; ao centro é a releitura - sempre e de novo - de Nietzschel Freud/Wittgenstein. ${ }^{19}$

É fácil rastrear tais referências, evidenciadas no livro. O descrédito a Foucault talvez se deva menos ao autor francês do que pelo grande modismo em Veneza de seus escritos, como atesta o livro "O dispositivo Foucault", lançado pelo Instituto (colocar o nome do Instituto) também em 1977, com textos de seus principais filósofos (Rella e Cacciari), de Georges Teyssot e do próprio Tafuri. Interessante notar no trecho acima o enquadramento de suas referências como releitura. Trata-se de um movimento símile ao "Projeto e utopia", no qual autores usualmente considerados na obra do autor são revisitados, com uma nova ótica.

O "Projeto histórico", como obra de revisão, deve ser ladeado ao livro de Cacciari publicado em 1976, também com um caráter de revisão crítica, intitulado "Krisis, ensaio sobre a crise do pensamento negativo de Nietzsche a Wittgenstein".

Este livro foi particularmente importante para a reorganização intelectual das esquerdas na metade dos anos setenta, sendo "central para o desenvolvimento de subsequentes tendências na filosofia italiana, teoria política e prática." ${ }^{20}$

O livro formula uma crítica a quaisquer apriorismos adotados no esforço político. A Krisis é o objeto do trabalho do autor, sobretudo "a crise do pensamento negativo, da crítica do pensamento dialético como fator produtivo central da ideologia contemporânea." ${ }^{21}$ Segundo o autor, toda dialética sobre a crise acaba por reinseri-la nos processos produtivos, absorvendo-a dentro do sistema vigente. Já estava muito claro no período que o capitalismo tem uma estrutura consolidada e treinada para enfrentar crises graves do sistema, que em muitos casos a forçaram a reconfigurar-se

\footnotetext{
${ }^{19}$ Correspondência entre Manfredo Tafuri e Philippe Duboÿ, 10 de dezembro de 1977. Acervo pessoal do Professor Duboÿ.

${ }^{20}$ MANDARINI, Mateo. "Beyond Nihilism: Notes towards a critique of left-heideggerianism in italian philosophy of the 1970s". In: Cosmos and history-The Journal of Natural and Social Philosophy, v. 5, n. 1, 2009, p.38.

${ }^{21}$ CACCIARI, Massimo. Krisis: saggio sulla crisi del pensiero negativo da Nietzsche a Wittgenstein. Milão: Feltrinelli, 1976. Tradução para o espanhol: Krisis: Ensayo sobre la crisis del pensamiento negativo de Nietzsche a Wittgenstein. Cidade do México: Siglo Veintiuno Editores, 1982, p. 7.
} 
completamente, ou a grandes custos, para que o cerne das relações sociais seja preservado. Qualquer possibilidade de resistência, segundo Cacciari, em termos filosóficos, passa por uma consciência da premência da crise como ponto permanente de tensões que não se resolvem, que recusam, na qualidade de contraponto, transformar-se a partir de um salto de consonância com as correntes positivas.

A perspectiva do negativo como força independente é colocada nos termos de Cacciari como algo mais próximo a Nietzsche e sua ideia da vontade de poder do que dos termos marxistas. O filósofo deve ter em mente a pujança que o horizonte histórico impõe à sua prosa, sem no entanto perder de vista que esta não pode ser cotejada com modelos ou sistemas generalizados de síntese:

\begin{abstract}
Jamais em absoluto. Jamais racionalização definitiva, como aquela que emana de uma forma apriori, mas sim sistematização-logicização relativo-funcional para estas necessidades, para esta vida. Para esta vontade de poder. O Wille zur Macht de Nietzsche não somente procura 'recuperar' no plano puramente subjetivo a crise dos fundamentos científicos, mas também se posiciona como interpretação e resolução desta. Não é compreensivel senão sobre a base desta crise, com a qual compartilha radicalmente problemas e perspectivas. ${ }^{22}$
\end{abstract}

De acordo com Cacciari, a vontade de poder tem esta característica, de requerer constante exercício crítico. Este é o único modo pelo qual se pode extrair do presente toda a sua força transformadora.

Em “O 'projeto' histórico", temos um clamor pela postura símile dentro da perspectiva de contínuo labor do historiador no sentido de tornar pertinente a sua palavra. "O trabalho histórico", escreveu Tafuri, "é obrigado a trair-se conscientemente: a página final de um ensaio ou de uma pesquisa é necessária; mas vem interpretada como uma pausa que subentende pontos de suspensão."23

\footnotetext{
${ }^{22}$ Idem, p. 69. Grifos de Cacciari.

${ }^{23}$ TAFURI, Manfredo. "Il 'progetto' storico", Op. cit. p. 17.
} 
A concomitância geral destes dois trabalhos reside nesta postulação do trabalho do intelectual dentro da luta política como uma figura de atualização dos dilemas viscerais enfrentados pela história, tornando-a força motriz no presente. Isto implica diretamente na virtual infinitude de seus trabalhos, na medida em que até o final dos dias o teórico deve lançar-se ao estudo intensivo para fazer dele pulsar a força do momento. Isto está presente nos dois textos. Cacciari fala que uma "sistematização 'verdadeira' é aquela que permite a máxima extensão deste domínio, a extensão máxima mais compreensiva e mais econômica. Mas por ampla que esta seja, não se considera dentro de uma perspectiva in-finita." ${ }^{24}$ Tafuri, por sua vez, atesta que à história “é preciso se habituar a não pedir pacificações. Mas não precisará pedir nem mesmo que ela percorra ao infinito 'sentimentos interrompidos', para firmar-se atônita nos limites do bosque encantado das linguagens." 25

O termo 'projeto de crise' só apareceu de fato nesta segunda versão do artigo de Tafuri, depois de 1976 quando, na formulação final de "o 'projeto' histórico", temse um acento muito mais forte nas questões de Nietzsche (nos apelos à vontade de poder), Wittgenstein (na importância da palavra como instrumento para captar o instante presente) e Freud (nas comparações entre a infinitude da análise psicológica e o exercício do historiador). Tem-se, por esta rápida comparação com o texto de Cacciari, o sentido político ainda fortemente presente nos termos de Tafuri: o autor romano está, através de suas pesquisas, buscando inserir-se nos debates e temas dos círculos intelectuais italianos de esquerda.

Entretanto, entre Tafuri e Cacciari, houve uma separação no que concerne os modos de seus engajamentos. Tafuri, após "O 'projeto' histórico”, passa a afastar-se das questões ligadas ao contemporâneo, iniciando um processo que terminaria pela decisão de parar de lecionar sobre a arquitetura de sua época. Já Cacciari permaneceu firme ao engajamento presente; tornou-se prefeito de Veneza em 1995, publicou vários livros sobre a urgência das questões políticas e até hoje está nos noticiários como personagem ativo dos rumos da península.

Essa modificação leva a crer que o Projeto é um ponto de inflexão. Interpretálo como síntese implica ignorar essa transformação na postura de Tafuri: a força

\footnotetext{
${ }^{24}$ CACCIARI, Massimo. Krisis, Op. cit. p. 69.

${ }^{25}$ TAFURI, Manfredo. "Il 'progetto' storico", Op. cit. p.18.
} 
política dos textos de Tafuri deixou de ser explícita. Desde então, os textos do historiador exigem uma mediação para que se compreenda a sua interlocução com a atualidade. Tafuri percebe a diferença existente no trabalho do filósofo e do historiador. "Teorias e história", bem como "Projeto e utopia", são obras que possuem uma estruturação símile com os artigos de sua fase radical na Contropiano: tem uma mensagem forte que conclama os arquitetos e intelectuais a mobilização. 'Mobilização' não em termos literais, mas como articulação e formulação do "processo de construção da alternativa revolucionária". As conclusões tanto de "Projeto e utopia" quanto de “Teorias e história” - mas também de L'Architecture dans le boudoir, ou "As cinzas de Jefferson”, “Arquitetura Contemporânea” - trazem certa vontade de movimentação, seja como contraposição às leituras estetizantes da história da arquitetura, seja pela postulação direta da presença política da figura do historiador.

Tal vontade e postulação estão presentes no projeto histórico. Entretanto, são como a imagem benjaminiana, a mais brilhante manifestação de um tipo que é, ao mesmo tempo, sua ruína. $\mathrm{O}$ "projeto de crise" refere-se mais aos seus trabalhos futuros do que passados. Entre "Krisis" e "O 'projeto' histórico" vê-se a diferença, presente na última sentença do artigo de Tafuri: a história deve estar disposta a arriscar uma provisória 'inatualidade’, termo distante do ensaio de Cacciari, tão ávido por prender o presente com sua crítica.

$\mathrm{O}$ artigo de Tafuri, nesta perspectiva, não pode ser visto como uma síntese, mas como mais uma obra de inflexão no corpus do autor: possui uma revisão crítica de referências, teor metalinguístico das frases e a compactação do humanismo e do contemporâneo como formalizações de um dilema único acerca da significação das cidades. Trata-se de um importante ponto de inflexão, mas de modo algum deveria servir como resumo da contribuição de Tafuri.

Dois trabalhos se sobressaem dentre os mais marcantes realizados sobre o tema, pela sua amplitude e pelo caráter monográfico. O primeiro foi escrito por um ex-aluno de Tafuri, Marco Biraghi, que corajosamente publicou em italiano um trabalho intitulado "Projeto de crise", focando-se na produção contemporânea de Tafuri como recorte estratégico para "fornecer uma ajuda fundamental à compreensão da conjuntura arquitetônica contemporânea. ${ }^{26 ”}$ Outro trabalho é assinado pelo

\footnotetext{
${ }^{26}$ BIRAGHI, Marco. Progetto di crisi. Op. cit., p. 8.
} 
australiano Andrew Leach, intitulado "Escolhendo história", em que o autor realiza um itinerário geral pela obra de Tafuri, concentrando-se no denominador comum de sua carreira, a sua argumentação sempre em favor do historiador. "Para Tafuri, acreditamos, os produtos da prática histórica afinal perpetuamente se desfazem. (...) Justamente pelo modo como Tafuri lida com estas frustrações que seu trabalho é tão importante hoje. ${ }^{27 "}$

No que concerne a temporalidade, ambas obras trazem contribuições. Biraghi leva ao limite a verve ensaística de seu professor para compreender o que aparecia como seminal em sua obra: exercitar um suposto 'dom da palavra', conseguir criar um 'ensurdecedor silêncio' dentro de seu campo. Certamente, o milanês escreve inspirado pelas ideias do "projeto' histórico". Tal inspiração gera um efeito interessante na prosa do ensaio: assim como Tafuri fazia um entremeio histórico de diversas obras de arquitetura, também Biraghi contrasta posicionamentos do autor com o de alguns intelectuais do século XX, como Karl Kraus, Walter Benjamin e Rem Koolhaas.

Esse procedimento permite que se coloque Tafuri como um intelectual eclético, cuja postura aprioristicamente contestatória, na opinião de Biraghi, consegue inseri-lo em debates para além da história da arquitetura, posicionando-o de modo amplo nas tendências intelectuais européias.

Sob o álibi da emulação da prosa de seu autor, Biraghi não faz um itinerário filológico. Seus raciocínios se baseiam nas obras "O 'Projeto' histórico”, “Arquitetura contemporânea" e em "Teorias e história”. Não seria um problema em si tomar como recorte apenas a obra de Tafuri sobre o contemporâneo, não fosse o defeito de excluir completamente um recurso que acredita-se visceral à contribuição histórica do historiador, que é a do cotejamento entre humanismo e presente. A opção por um lado dos escritos de Tafuri pode render raciocínios pontuais, mas um livro completo com o título grandioso de "Projeto de crise" não consegue se sustentar desse modo. Excluindo o aspecto mais marcante da prosa de seu professor - justamente aquele que fomenta e discute sua noção de tempo - Biraghi acaba por realizar menos que um texto de reiteração das teses de Tafuri: faz um retrato incompleto e demasiado particularista, estreitanto sua compreensão, ao invés de amplificá-la.

${ }^{27}$ LEACH, Andrew. Choosing history. Op. cit., p. 298. 
A versão de Andrew Leach, por sua vez, tem valor exclusivamente filológico. Pela primeira vez foi publicada uma sistematização da obra do autor, com uma atenção à bibliografia geral, e que procurou ter em mente as transformações pelas quais passou Tafuri durante a sua trajetória, costurando depoimentos pessoais com os textos do historiador.

Numa segunda parte, Leach procura analisar o corpus de Tafuri (sobretudo, “Teorias e história”, "Projeto e utopia”, “O 'projeto' histórico” e "Busca do Renascimento") com as filiações políticas do autor nos períodos nos quais foram escritas suas obras, as diferentes escolas intelectuais que foram referenciais para os seus raciocínios, como Freud, Cacciari, a escola dos Annales etc. É impressionante a genealogia de cada artigo, o modo como "Teorias e história" é visto como um ponto de chegada das primeiras aulas dadas pelo jovem historiador nos cursos de Roma e Palermo, como entre a primeira versão de "O 'projeto' histórico" - aquele compêndio sobre método publicado na Arte Veneta - e o texto definitivo entra em cena uma maior preocupação com as referências bibliográficas e com uma vontade de discutir sobretudo o 'recalque' na história das cidades.

Porém, as análises de Leach são muito conservadoras. Sem sair das referências e linhas de Tafuri, o teórico australiano avança apenas na parte final do seu texto, em que lança questões chave: “qual é o 'projeto' de Tafuri? Sua leitura da arquitetura revela a 'condição crítica' da modernidade? Como podem os historiadores (ou arquitetos) participarem na 'luta de classes??"28

As perguntas de Leach são sintomáticas, pois colocam a colaboração de Tafuri na conjuntura, no contexto presente. Sua busca por uma partícula elementar que dê atualidade ao seu 'projeto' leva o teórico australiano a construir uma dicotomia entre um historiador que investigava o passado de forma pragmática, para distingui-lo do presente, e outro que subscrevia-se à esfera do sonho, da impossibilidade de se chegar a conclusões, do corpo vivo da história ${ }^{29}$.

A separação entre textos filológicos, monografias mais acadêmicas e o lado ensaístico constroem um Tafuri dividido entre o pragmatismo e o devaneio. Leach intui nessas linhas a dialética existente entre suas obras, mas não aprofunda como elas

\footnotetext{
${ }^{28}$ LEACH, Andrew. Choosing history. Op. cit., p. 62.

${ }^{29}$ Idem, p. 300.
} 
apontam para caminhos distintos em diferentes fases da trajetória do autor romano. $\mathrm{O}$ australiano deixou uma tarefa por cumprir, na soleira das suas conclusões mais óbvias acerca do autor quando poderia ter formulado hipóteses mais incisivas. O próprio título do livro, "Escolhendo história", procura comportar o autor romano dentro dos parâmetros por ele próprio estabelecidos: na busca dos meandros que fizeram de Tafuri um historiador - e não um arquiteto - o que acarreta em uma obra menor ao tratar dos temas mais complexos levantados pelo professor.

Para além desses dois trabalhos, existe uma ampla senda de comentadores que estudaram pontos particulares da obra de Tafuri em ensaios e artigos, aprofundando aspectos de sua contribuição e revelando novos horizontes de investigação.

$\mathrm{Na}$ sua maioria, elas entram nos estudos das obras de Tafuri pelos seus trabalhos de maior projeção. Não existiu artigo sobre o historiador que escapasse dos dilemas expostos em "Projeto e utopia". Traduzido em cinco línguas, foi o texto que lhe deu maior repercussão. Escrito no final dos anos sessenta como um artigo intitulado "Por uma crítica da ideologia arquitetônica", como texto de estreia na revista Contropiano, ele é testemunho de um período particular da carreira de Tafuri em que consolidava sua posição como professor ordinário em Veneza ao mesmo tempo em que as esquerdas italianas passavam por uma reorganização dramática em torno de um Partido Comunista tensionado por movimentos estudantis e operários de diferentes correntes na península. Soma-se ao conturbado período a já exaustivamente estudada condição de impasse da arquitetura de inspiração modernista que sofria relativizações das tendências ditas 'pós' modernas, e mesmo de revivals e reafirmações de diversas naturezas e orientações políticas.

$\mathrm{O}$ argumento do livro centra-se nos discursos, investigações e construções feitos pelas correntes de arquitetura europeia e americana partindo do século XVIII até os anos sessenta, nos quais Tafuri procura revisitar os mais marcantes movimentos do período e mostrar como toda a gama de rupturas imbuída nas pesquisas sensoriais e subversão de preceptivas possuem um pano de fundo cheio de compromissos com a consolidação da metrópole industrial real, desordenada, precária e informe. Conforme o autor, as utopias desenhadas pelas vanguardas são ideologias a serviço involuntário do capital industrial, cujo interesse nas cidades não intervém tanto na sua forma como 
no seu sistema geral, o que o faz indiferente à precariedade urbana que rege o crescimento dos grandes centros urbanos.

Muitos foram os autores que correram em defesa das correntes contemporâneas, protegendo-as dos argumentos de Tafuri, compreendidos como o atestado de uma 'morte da arquitetura'. Críticos como Agnoldomenico Pica e Robert Fishman escreveram resenhas afirmando que o autor romano propunha que "os arquitetos que realmente querem mudar o mundo devem abandonar suas pranchetas e sair às ruas." ${ }^{30}$

Realmente, a prosa do autor romano possuía certo tom de ceticismo a qualquer arquitetura de contramão. Ficou muito conhecida a passagem do livro "Projeto e utopia” em que os termos de uma arquitetura revolucionária são solapados:

\section{(...) Tal como não pode existir uma Economia politica} de classe, mas uma crítica de classe à Economia politica, também não é possivel criar uma estética, uma arte, uma arquitetura de classe, mas apenas uma crítica de classe à estética, à arte, à arquitetura, à cidade. ${ }^{31}$

Esta mensagem, colocada na conclusão do texto, deu margem à interpretação genérica de que aos arquitetos não existe outra saída senão girar em círculos, na medida em que qualquer crise da arquitetura não existe senão como reflexo de uma reorganização do capital que a fez uma atividade menos importante no jogo ideológico. Não surpreenderam, portanto, leituras como a de Tomas Llorens, que em um longo artigo de 1981 atesta que a conclusão do livro de Tafuri é que "a arquitetura, como tal, está condenada”32. Mesmo Fredric Jameson escreveu que para Tafuri "uma arquitetura do futuro só será concretamente e na prática possível somente quando o futuro chegar, ou seja, depois da total revolução social, uma sistemática transformação deste modo de produção em outra coisa"33.

\footnotetext{
${ }^{30}$ FISHMAN, Robert. "Utopia and its discontents". In: The Journal of the Society of Architectural Historians. v. 39, 1980, p. 154.

${ }^{31}$ TAFURI, Manfredo. Projecto e utopia. Op. cit., p. 121.

${ }^{32}$ LLORENS, Tomas. "Manfredo Tafuri: Neo-Avant-Garde and History". In: Architectural Design. v.51, 1981, p. 86.

${ }_{33}$ JAMESON, Fredric. "Architecture and the critique of ideology". In: OCKMAN, Joan (org.). Architecture, criticism, ideology. Nova Jersey: Princeton Architectural Press, 1985, p. 55.
} 
Por outro lado, outros autores formularam visões mais distanciadas do teor literal desta passagem, para colocá-la em perspectiva histórica. Na obra de Jean-Louis Cohen, "a ruptura entre arquitetos e intelectuais, ou as lições da italofilia”, pela primeira vez aparece uma interpretação mais ampla de "Projeto e utopia", na qual o autor francês vê que Tafuri coloca "a arquitetura moderna na perspectiva das transformações do modo de produção capitalista da qual ela é parte integrante, tanto do ponto de vista material quanto o ponto de vista simbólico." ${ }^{34}$

Cohen aproxima Tafuri das teses revisionistas de Althusser, segundo as quais a ideologia seria mais do que um falso julgamento da consciência, configurando-se como uma representação do mundo. Assim, mais do que um ponto final nas propostas da arquitetura moderna, o texto do historiador romano seria sobretudo uma abertura da visão. Esta conexão com o universo simbólico permitiria que Tafuri visse a ideologia do plano como uma segunda leitura das metrópoles. Neste sentido o trabalho geral de explicitação das utopias das vanguardas aparece complexificado para além de um recalque negativo solapado pela reorganização geral do capital ocorrida ao princípio dos anos trinta.

Reforça esta linha de argumento um livro de 2011 de autoria de Gail Day, no qual se investiga a concomitância entre cenário político no Vêneto e a posição dos intelectuais de esquerda dentro do círculo da Revista Contropiano. Segundo o autor, "nenhum dos projetos iniciados por Tafuri, ou as linhas de argumento desenvolvidas através deles, podem ser adequadamente compreendidas fora do grande projeto político moldado pela cultura intelectual do operaismo. ${ }^{35 "}$

De fato, o artigo posteriormente transformado no livro "Projeto e utopia" foi a primeira contribuição de Tafuri para a Contropiano. O corpo editorial que perdurou ao longo da existência da publicação era composto sobretudo por Alberto Asor Rosa e Massimo Cacciari. O crítico literário Asor Rosa era já conhecido na península pelo seu livro "Escritores e povo" e possuía certa experiência como colaborador de revistas ligadas ao operaismo como os Quaderni Rossi. O filósofo Massimo Cacciari era, na ocasião, recém formado pela Universidade de Padova. Cacciari atuava em Veneza, e Tafuri, recém nomeado professor ordinário, inseriu-se no círculo do jovem filósofo,

\footnotetext{
${ }^{34}$ COHEN, Jean-Louis. "La coupure entre architectes et intellectuals". Op. cit., p. 205.

${ }^{35}$ DAY, Gail. Dialectical passions. Negation in postwar art theory. New York: Columbia University Press, 2011, p. 115.
} 
onde encontraria colegas como Francesco Dal Co e Marco de Michelis, estabelecendo com eles relações duradouras.

A revista, de acordo com o "Primeiro balanço" publicado pelos seus editores, via na Itália uma "situação de classe múltipla e contraditória, efervescendo de possibilidade e força, que espera ser conhecida teoricamente e reorganizada, para que dela nasça o que ela já parece indicar e propor - o processo de construção da alternativa revolucionária. ${ }^{36 ”}$

Essa intenção organizativa, apesar de tolerar um caráter 'múltiplo', certamente requeria de seus colaboradores concisão política. O operaismo era um movimento italiano que orbitava em torno de algumas pautas do PCI sem subscrever-se completamente a ele, o que resultou no surgimento de diversos pequenos partidos dissidentes dentro do cenário político peninsular, reafirmando em diversas tendências a importância do movimento trabalhista no pós guerra europeu e, especificamente, na reorganização econômica pela qual passava a Itália. Uma pauta comum a estas várias tendências era ordem do dia dentro da editoria da Contropiano, junto com as lutas estudantis que marcavam também a década no país.

Day faz um itinerário acerca das concomitâncias de Tafuri e sua crítica à ideologia arquitetônica dentro da Itália. Em um artigo preparatório para seu livro, Day faz a correlação de experiências como as do bairro Tiburtino em Roma e sobretudo a gestão do PCI na cidade de Bolonha, feita à maneira dos bairros operários de Frankfurt na Alemanha pré-guerra, para explicar as duras críticas de Tafuri às experiências germânicas ${ }^{37}$. $\mathrm{Na}$ prosa do autor inglês também aparece a proximidade entre as ideias de Tafuri e Cacciari durante os anos sessenta e setenta, como um momento de nova formação política do autor romano na ocasião de sua chegada em Veneza. Tafuri já tinha publicado algumas obras sobre arquitetura contemporânea e moderna, sob a tutela de arquitetos mais velhos, como Giuseppe Samonà, Leonardo Benevolo e Ernesto Nathan Rogers. Fora, segundo suas palavras, apadrinhado por Bruno Zevi na sua posição como professor ${ }^{38}$. Não obstante, tinha também deixado

\footnotetext{
36 "Primo bilancio". In: Contropiano. n. 2, 1968, p. 239.

${ }^{37}$ DAY, Gail. "Strategies in Metropolitan Merz: Manfredo Tafuri and the Italian Workerism". In: Radical Philosophy, v.133, 2005, p. 33.

38 "Zevi [chefe da banca do concurso] tinha apenas uma coisa na cabeça: que eu vencesse." "History as Project: An Interview with Manfredo Tafuri”, feita por Luisa Passerini, In: ANY: Being Manfredo Tafuri, n. 25 e 26,2000 , p. 34
} 
para trás uma carreira como arquiteto, dentro do "Studio AUA", de sua fundação. Era bem inserido no meio arquitetônico italiano tendo o amplo campo das ciências humanas sempre presente na sua formação desde sua infância. Leitor de Sartre e Camus, também assistiu às aulas de Giulio Carlo Argan e acompanhou os escritos de Panzieri, Tronti e Asor Rosa, enquanto conciliava os estudo com sua rotina de aluno engajado dentro da faculdade de arquitetura Valle Giulia, onde perpetrou, junto de colegas como Vieri Quilici e Giorgio Ciucci ocupações e revoltas contra os professores fascistas que permaneciam em seus quadros.

Segundo Day, “Tafuri era um partidário da ala de Tronti. ${ }^{39 ”}$ A afirmação é plausível, assumido que este intelectual foi central tanto para o operaismo quanto para uma nova formulação da crítica da ideologia. É difícil, no entanto, ver no quadro amplo da obra de Tafuri um alinhamento com Mario Tronti mais forte do que com as correntes de pensamento acerca da 'cidade território' (Quaroni, Samonà, Piccinato...) e da sua prática arquitetônica, e posteriormente com o núcleo que fazia a revista Contropiano - sobretudo Massimo Cacciari. Como o próprio historiador romano diria:

Quando Cacciari entrou para a faculdade em Veneza, ele fez um seminário sobre "O capital", de Marx. Nós usualmente iamos escutar as falas uns dos outros, mas não creio ter jamais testemunhado uma mais violenta demolição do monstro sagrado. Cacciari demonstrou que entre o primeiro e o terceiro livro do "Capital" existia um abismo de escolhas, e que Marx achou impossivel decidir devido aos vários problemas encontrados. Nesta construção, Marx era simplesmente um historiador do século XIX com fortes intuições historiográficas. Isto era, para nós, a manifestação da crítica à ideologia. ${ }^{40}$

No limite, as questões do operaismo, e mesmo as mais amplas das questões urbanas em Bolonha e Roma, podem ter chegado ao Tafuri pré-Veneza por seus colegas arquitetos - e por Tronti e Asor Rosa - mas a construção política de sua

\footnotetext{
${ }^{39}$ DAY, Gail. Dialectical Passions. Op. cit., p. 114.

40 "History as Project", Op cit., p. 59.
} 
contribuição à história da arquitetura passa por um grupo particular dentro da Contropiano: os arquitetos Marco de Michelis e Francesco Dal Co, e sobretudo o jovem editor Massimo Cacciari, em grande parte responsável por sua virada teórica.

Os textos "Por uma crítica da ideologia arquitetônica" e "Projeto e utopia" são testemunhos desta transformação. Não é somente o primeiro artigo de Tafuri na Contropiano, em que o romano queria mostrar sua filiação aos temas ali desenvolvidos, mas é a primeira publicação em uma revista de esquerda fora do campo da arquitetura. Se comumente atribuem a Tafuri uma ultrapassagem dos dilemas então recorrentes na mesa dos teóricos de arquitetura para outros círculos das ciências humanas, este ambicioso texto sobre a ideologia na arquitetura é certamente o ponto inicial de sua contribuição. Ao mesmo tempo, completados quarenta anos de sua publicação, o seu legado mostra-se frágil e, em certo sentido, datado se não for levada em conta toda sua obra. O livro pertence àquela classe de trabalho no qual se pode ter uma boa noção de como pensava um autor em determinado período de sua carreira, o que consequentemente fornece uma visão demasiado fragmentada. Para os novos leitores de Tafuri isso não resulta necessariamente em um problema, se tivermos em conta diversas relações que podem ser tiradas das considerações gerais que o romano faz sobre as metrópoles e suas utopias, em comparação direta com outros intelectuais.

Dentre os leitores de "Projeto e utopia", é preciso atentar para a colaboração de Ilaria Brocchini e seu trabalho em apontar relações particularmente interessantes com o filósofo alemão Walter Benjamin. Em sua tese de doutorado "Rastro e desaparição na obra de Walter Benjamin”, a teórica baseia-se na noção de 'rastro' que o filósofo tece no livro "Passagens" (“Aparição múltipla de uma realidade próxima, por mais distante que ela possa parecer") sobre os interiores no século XIX, argumentando como o texto "Projeto e utopia", ao estabelecer a metrópole como reduzida à mercadoria, complementa as considerações contidas no trabalho póstumo de Benjamin.

Brocchini foi perspicaz ao construir uma relação insuspeitada entre Manfredo Tafuri e Walter Benjamin uma vez que o trabalho das "Passagens" foi publicado décadas depois de "Projeto e utopia". Ela conseguiu aprofundar os termos da relação entre Tafuri e o filósofo berlinense, cuja obra foi traduzida para o italiano em 1962, e 
as citações de diversos de seus ensaios são inúmeras em qualquer artigo com maior viés crítico que o autor romano tenha publicado ${ }^{41}$.

Neste sentido, existe um salto importante na qualidade das asserções dos comentadores que ampliam o corpus de seus textos. Não só por uma melhor compreensão do contexto em que foi escrito "Projeto e utopia", mas também por dar mais pertinência e atualidade histórica à contribuição de Tafuri. Muitos autores tecem em seus trabalhos comparações acerca deste livro escrito em Veneza com um outro grande compêndio teórico desenvolvido pelo autor entre 1966 e 1967, publicado em 1968.

"Teorias e história da arquitetura" é uma obra metodológica para a reformulação dos parâmetros críticos da arquitetura. Seu discurso visa enquadrar as rupturas das vanguardas e sua pretensão de fundação de um novo tempo da arte em um arco mais amplo do que aquele que a colocava como um desdobramento das teorias racionalistas do Iluminismo. De acordo com o livro, a negação da história remonta a tempos anteriores à modernidade do ocidente, sobretudo, ao Renascimento.

Apoiando-se nesta tese, Tafuri passa a mostrar como, apesar dos arquitetos trabalharem livremente com a história, o crítico não conseguiria por sua vez sustentar seu trabalho sem esforço para ver o objeto de seu trabalho a partir de uma rigorosa perspectiva histórica. Neste sentido, Tafuri tece as conhecidas separações entre os arquitetos e historiadores, atacando duramente os escritores que "têm a ilusão de poder projetar mais com a pena do que com o tecnígrafo" ${ }^{2}$, o tipo de texto que constrói livremente as referências históricas para endossar determinados movimentos e correntes de artistas - o que o autor romano chamava 'crítica operativa'. No lugar dela, advogou pela busca de novo lastro nas pesquisas linguísticas e estruturalistas, ladeado

\footnotetext{
${ }^{41}$ Sobre Benjamin e Tafuri: KEYVANIAN, Carla. Manfredo Tafuri's notion of history and its methodological resources: From Walter Benjamin to Roland Barthes. Cambridge: Master Degree, Department of Architecture, MIT, 1992. Apesar do recorte bem fundamentado de Keyvanian, o trabalho perde força ao tentar submeter tanto Tafuri quanto Benjamin aos parâmetros marxistas de avaliação da realidade - e por subscrever-se a uma leitura metodológica de sua relação com a história, algo incomum a Tafuri e sobretudo a Benjamin. Ainda sobre a relação com o pensamento de Benjamin, é fundamental partir das crônicas que Andrew Leach faz sobre os estudos de Tafuri sobre Borromini em 1978: LEACH, Andrew. "Francesco Borromini and the Crisis of the Humanist Universe, or Manfredo Tafuri on the baroque origins of modern architecture", In: The Journal of Architecture. v. 15, n. 3, junho de 2010 que será estudado a seguir.

${ }^{42}$ TAFURI, Manfredo. Teorie e storia dell'architettura. Bari: Laterza, 1968. Tradução para o português: Teorias e história da arquitetura. Lisboa e São Paulo: Presença e Martins Fontes, 1979, p. 288.
} 
por uma maior pesquisa filológica - documentos, textos e desenhos de época - como forma de dar maior precisão às considerações feitas pelo historiador.

Apesar de escrito apenas dois anos antes de "Projeto e utopia", o livro tem um estilo de prosa menos conciso, as comparações entre períodos históricos são mais livres, os argumentos se interrompem e são retomados posteriormente. Tomas Llorens chamava "Teorias e história" de "um palimpsesto, um documento onde os sucessivos e frequentemente contraditórios discursos de crise são justapostos, mais do que agregados. ${ }^{43 "}$ Panayotis Tournikiotis, teórico grego, no seu livro sobre moderna historiografia, descredencia o livro de Tafuri ao julgá-lo como uma obra na qual "suas respostas são elípticas, ora sobrepostas, ora contraditórias, e com muita frequência indefinidas. Nenhuma explicação é dada, por exemplo, para as três palavras que formam o título: 'teoria', 'história' e 'arquitetura', que vacilam de capítulo em capítulo, sem nunca chegar a um simples significado, como esperamos." ${ }^{44}$

Tafuri estava na ocasião francamente influenciado pelas discussões no campo linguístico, seja pelas leituras das "Mitologias", de Barthes, ou pelas passagens de "Obra de arte na era de sua reprodutibilidade técnica”, de Walter Benjamin. Disto resultou o caráter menos objetivo de sua argumentação. Entretanto, apesar de uma estilística diferente é possível ver traços constitutivos de "Projeto e utopia" em linhas gerais: o engajamento político, apesar de longe do programa do operaismo já estava presente, mesmo em suas possibilidades de tornar a história da arquitetura em crítica à ideologia. "A atividade histórica," escreveu Tafuri, "na mais total indiferença no confronto com a ação positiva, torna-se, assim, 'crítica das ideologias arquitetônicas' e, enquanto tal, 'atividade política' - ainda que mediatamente política." 45

Quando o foco é expor os antecedentes da postura negativa de Tafuri acerca dos movimentos das vanguardas, usualmente os seus comentadores veem continuidade nestas duas obras. Hoekstra, em sua tese de 2005, estabelece os termos de uma continuidade entre as duas obras no sentido mais direto: os instrumentos da crítica formulados pela primeira desdobram-se na outra:

\footnotetext{
${ }^{43}$ LLORENS, Tomas. "Manfredo Tafuri: Neo-Avant-Garde and History".Op. cit., p. 85.

${ }^{44}$ TOURNIKIOTIS, Panayotis. The historiography of modern architecture. Cambridge e Londres: The MIT Press, 1999, p. 194.

${ }^{45}$ TAFURI, Manfredo. Teorie e storia dell'architettura. Op. cit. p. 290. Grifo de Tafuri.
} 
O livro [Projeto e utopia] era parte de um novo programa crítico de questionamento do lugar das ideologias arquitetônicas dentro de um sistema capitalista dominado pela racionalidade. O divórcio de Tafuri das práticas normativas da critica operativa, realizada em "Teorias e bistória...", permitiram-lhe ver arquitetura nos termos de uma complexa relação com a sociedade. ${ }^{46}$

Neste binômio, no qual uma parte é o preparativo metodológico da outra, é possível encontrar reverberação dos prólogos de Tafuri para as edições de "Teorias e história" posteriores à publicação de "Projeto e utopia". "Entre 'Teorias e história' e o mais recente 'Projeto e utopia' a relação é, todavia, direta: o primeiro é apenas o 'prólogo no céu' do segundo." 47

Andrew Leach é um dos poucos que relativiza esta conexão direta. Em sua tese de doutorado, aponta que em “Teorias e história” existe uma relação 'muito mais leve' com os movimentos operários em ação na península durante sessenta e oito do que os seus textos de engajamento sobre Roma no princípio de sua carreira. ${ }^{48}$

O engajamento mais vago aparece nas citações da obra de Marx “O 18 de Brumário de Luís Bonaparte”, e também na sua abordagem mais branda da questão ideológica na arquitetura. Não se trata de uma diferença de teor crítico, como se "Projeto e utopia" fosse a radicalização dos temas de "Teorias e história". Sobressai nas linhas deste livro anterior a Veneza uma visão ainda positiva das vanguardas: "para qualquer revolução os mitos são as ideias força necessárias e indispensáveis para forçar a situação. Mas quando a revolução - e não há dúvida que as vanguardas artísticas do século XX combateram por uma revolução - atingiu os seus objetivos, faz-se sentir a falta do apoio que a crítica encontrava anteriormente no seu compromisso total com a causa revolucionária." ${ }^{\prime 9}$

O autor romano também privilegia nesta obra as rupturas das vanguardas. Parte do pressuposto que estes artistas do princípio do XX engendraram uma cisão

\footnotetext{
${ }^{46}$ HOEKSTRA, Titia Rixt. Building vs. Bildung: Manfredo Tafuri and the construction of a historical discipline. Groningen: Tese de doutorado. Groningen University, 2005, p.189.

${ }^{47}$ TAFURI, Manfredo. "Prólogo à quarta edição italiana". In: Teorie e storia dell'architettura, Op. cit. p. 17.

${ }^{48}$ LEACH, Andrew. Choosing history. Op. cit. Sessão 11, p. 30.

${ }^{49}$ Idem, p. 21.
} 
com períodos anteriores - não pela livre manipulação da história, como fizeram os renascentistas, mas pelo seu total apagamento e vontade de construção de uma completamente nova ordem. Neste sentido, não é surpresa que, apesar dos comentadores verem continuidade nas duas obras, esta impressão seja a oposta nos depoimentos vindos dos colegas de Instituto de Tafuri, para quem a sucessão delas deixava uma sensação de contraste.

Francesco Dal Co aponta para uma "diferença abissal evidente" ${ }^{50}$ entre as duas obras, pela diferença de propostas ideológicas. Dal Co marca a peculiar formação de Tafuri no período anterior à cátedra no IUAV, como aquela "de um historiador marxista com forte interesse sobre os temas da linguística." ${ }^{51}$

Marco De Michelis, mais específico, diz que ao chegar em Veneza, Tafuri foi convidado a escrever na Revista Contropiano por Cacciari, e fizera de fato um texto muito celebrado, 'redimindo' sua obra anterior, que por sua vez não agradava à ninguém. "Nem ao Asor Rosa, nem ao Tronti", disse De Michelis, "e de todo modo nem mesmo ao Cacciari, porque era um ensaio ainda distante do tema marxista da crítica à ideologia, era um ensaio muito mais ligado ao pensamento crítico da Escola de Frankfurt, do modo um pouco desajeitado que Argan interpretou a Escola de Frankfurt." ${ }^{52}$

De acordo com os testemunhos, entre as duas obras havia distinção nos modos de engajamento político. "Teorias e história" está excessivamente ligado aos temas da arquitetura, passando claramente pelos escritos de Argan como "Projeto e destino", e, sobretudo, "Salvação e queda da arte moderna", em que as questões frankfurtianas em sua maioria da autoria de Walter Benjamin- aparecem de maneira a advogar pelas mais viscerais postulações da arte moderna.

Baseando-se em "Obra de arte na era de sua reprodutibilidade técnica”, Tafuri subscreve em linhas gerais os escritos de Argan, para quem o modernismo poderia ganhar um novo fôlego mediante a restauração de suas postulações primeiras, resumidas no termo 'projeto', em que o mestre romano colocava uma grande

\footnotetext{
${ }^{50}$ Depoimento de Francesco Dal Co feito ao autor em 29 de outubro de 2010.

${ }^{51}$ Idem.

${ }^{52}$ Depoimento de Marco De Michelis feito ao autor em 27 de outubro de 2010.
} 
virtualidade redentora. "Não se projeta nunca para”, escreveu Argan, "mas contra alguém ou algo." 53

Apesar de falar sobre as tarefas da crítica de arquitetura e dirigir seu foco sobre os autores de seu tempo, tem um teor muito diferente do sistemático ensaio publicado nos anos seguintes que, não à toa, intitula-se "Projeto e utopia" em um claro caráter paródico e negativo aos textos de Giulio Carlo Argan. Ali o autor responde ao seu professor romano, acerca do interesse em opor 'projeto' a 'destino':

O destino da sociedade capitalista, numa tal base, não é efetivamente estranho ao projeto. A ideologia do projeto é tão essencial à integração do capitalismo moderno em todas as estruturas e superestruturas da existência humana, como o é a ilusão de poder opor-se a esse projeto com os instrumentos de um projeto distinto, ou de um 'antiprojeto' radical. ${ }^{54}$

A ruptura de Tafuri com estas duas obras é também resultado de uma revisão de suas referências críticas. "Teorias e história” é um primeiro momento de cisão. Capítulos como "A crítica operativa" deixam clara a divergência do método concebido por Tafuri em relação àquele proposto por Benévolo, Pevsner e Zevi. Complementa este processo o livro "A idade do humanismo", publicado na mesma época, em que o autor busca realizar uma nova leitura do Renascimento em contraste com a de Wittkower. Entretanto, estes autores serão excluídos da bibliografia do autor nos anos venezianos - trata-se realmente de um corte radical. Bruno Zevi, que defendera Tafuri na obtenção da cátedra de história de arquitetura rompe definitivamente com o autor em correspondência de 1972, na qual ataca o rebelde pupilo perguntando-lhe "até quando crês que pode ter eficácia a tua máscara de teutônica cientificidade atrás da qual esconde a falta de ideias, de sensibilidade pela arquitetura e alegria humana?”55

"Projeto e utopia" não é tão hostil aos teóricos contemporâneos. Por outro lado, trata-se de um momento em que autores importantes para o jovem Tafuri são revisitados: Argan não tem seu 'projeto' atacado in toto mas, seguramente, o professor

\footnotetext{
${ }^{53}$ ARGAN, Giulio Carlo. Progetto e destino. Milão: Il Sagiattore, 1977, p. 63 e ss.

${ }^{54}$ TAFURI, Manfredo. Projecto e utopia. Op. cit. p. 121.

${ }^{55}$ Correspondência de Bruno Zevi a Manfredo Tafuri de 28 de junho de 1973. Acervo da Fondazione Bruno Zevi.
} 
de Veneza deixa para trás qualquer boa fé existente na empreitada vanguardista, especialmente no que concerne possibilidades de emancipação. A tal 'revolução' engendrada pelos alemães e franceses, pelo urbanismo de Corbusier na Ville Radieuse ou mesmo pelas experiências urbanísticas de Kahn na Filadélfia e de Tange para Tóquio não têm lugar no seu artigo para a Contropiano. Mesmo Benjamin, filósofo alemão central na obra de Tafuri desde as primeiras versões italianas dos seus ensaios publicados na península, é lido de modo diferente por Tafuri nestas duas obras. $\mathrm{Na}$ primeira, é maior o interesse pelo "Obra de arte na era de sua reprodutibilidade técnica”, texto mais programático do filósofo, no qual ele se esforça para, através de uma crítica dos parâmetros artísticos aplicados à máquina, dar novas perspectivas aos artistas de vanguarda. "Projeto e utopia" sustenta-se nos argumentos de "Sobre alguns temas de Baudelaire”, obra da maturidade de Benjamin no qual aparecem menos saídas para a crise das vanguardas europeias - que então viviam os auspícios da segunda guerra - e surgem maiores investigações livres sobre a experiência e fragmentação do indivíduo dentro da Paris pós revolução e pós comunas. No primeiro ensaio, Tafuri adere aos termos do alemão na busca de uma cultura de massas, de grandes mobilizações e na esperança de criar uma forma que fale às massas. Por outro lado, em "Projeto e utopia", Tafuri escolhe os textos mais melancólicos de Benjamin, nos quais as massas aparecem menos dotadas de uma virtualidade revolucionária.

"Teorias e história" tem um caráter complementar ao "Projeto e utopia" como um processo geral de emancipação, mais do que de uma continuidade de formação marxista, ou qualquer outro atrelamento a vieses políticos. Esta primeira obra, em parte pela sua prosa que busca uma síntese e em parte pelo seu conteúdo metodológico, foi também bastante traduzida e divulgada, seguindo a fama do artigo para a Contropiano. Dentre os comentadores de Tafuri, quando estes não a utilizam como pano de fundo para "Projeto e utopia", sua análise aparece associada a um marco da juventude do autor, a primeira obra de personalidade por ele publicada.

"Projeto e utopia" e "Teorias e história da arquitetura" são as obras conhecidas de Tafuri que compõem o corpus dessa tese. Integra-se a estas o texto seminal sobre Le Corbusier de 1979 (muito bem desenvolvido por Lipstadt e Mendelsohn), "Machine et memoir: a cidade na obra de Le Corbusier" e a conferência de 1993 que Tafuri dedica ao tempo, "A dignidade do átimo". Acredita-se que, tendo como pano de fundo toda 
a obra do autor romano, sem perder de vista obras importantes como "Arquitetura do humanismo" e "Busca do Renascimento", pode-se tecer uma construção nova acerca de seu pensamento, sem apelar para elucubrações alheias aos termos com que ele circunscreveu a sua própria contribuição.

Fosse um itinerário sobre o tempo, poder-se-ia utilizar uma estruturação mais calcada no aprofundamento de cada um desses textos e detalhar o 'tempo congelado' e outras categorias se sobressaem. Entretanto, ao analisar a questão da temporalidade, é possível revisitar toda a obra de Tafuri e ressignificar muitas de suas decisões centrais e exaustivamente fruto de ponderações, como a sua escolha pela história em detrimento de seu escritório de arquitetura, sua guinada para o humanismo a partir de 1981 e, sobretudo, seu contínuo afastamento, desde 1959 até 1994, das questões conjunturais de seu tempo, para a formulação de uma reflexão mais profunda dos significados da arquitetura desde tempos longínquos.

Pensar a categoria do tempo em Tafuri leva à questão dos modos pelos quais se pode ler a arquitetura em sua interferência no real. O primeiro capítulo refere-se à sua atividade como arquiteto e historiador, sua adesão e questionamento aos fermentos das esquerdas italianas dos anos sessenta. Procura-se evidenciar como seu posicionamento como teórico advém não só de uma suposta 'vocação', conforme muitos comentadores sugerem, mas também da falência de uma indagação política do jovem Tafuri, e do surgimento de alternativas de atuação que requeriam de sua parte não só o direcionamento à escrita, mas também a formulação de uma disciplina sobre o tempo, um pensamento sobre a duração da arquitetura diante da cidade e da metrópole.

Um novo pensamento sobre o tempo antecede toda a revisão crítica de Tafuri dos anos setenta. Os meandros dessa transformação aparecem na fase 'radical' do autor (quando assina projetos como "Projeto e utopia", "L'architecture dans le boudoir", "Via Giulia” e "A cidade americana"), por meio de uma intensa revisão do papel da arquitetura, e também do arquiteto. Aos que projetam a cidade, existe uma potência do desenho e uma impotência de transformação política, o que leva o professor a formular um afastamento, no seu trabalho, do arquiteto como uma figura intelectual, para uma aproximação maior com a noção de personagem trágico. Uma nova noção de tempo demanda um novo protagonista, e o segundo capítulo procurará abordar as consequências dessa virada crítica do arquiteto. 
O terceiro capítulo da tese busca elucidar como o tempo nas cidades apresentase de modo distinto nas metrópoles de capitalismo e socialismo avançado e nos arrabaldes esquecidos e nas cidades históricas italianas. Procura-se costurar, tomando por base a produção sobre cidades de Tafuri entre os anos setenta e oitenta, um discurso no qual, se a temporalidade dos entremeios históricos abre indagações sobre a vida urbana, também as cidades são protagonistas de um drama trágico, e também elas são passíveis de polemizar e dialogar com os arquitetos.

O quarto e último capítulo tem um caráter de consolidação da noção temporal de Tafuri, tomando por recorte os últimos cinco anos de vida do autor. Em obras como "Busca do Renascimento" e na "Dignidade do átimo", serão explicitadas as direções de seus pensamentos sobre o tempo. Nos anos noventa, o debate generalizado em torno da temporalidade e secularização que acontecia na Itália inspira Tafuri a elaborar de modo mais claro o seu entendimento acerca do tempo, da história e da arquitetura.

Posto este quadro geral, espera-se abrir novas portas para o estudo de Tafuri, tecendo uma conclusão na qual retorna-se à revisão bibliográfica feita nestas primeiras linhas, procurando demonstrar a extensão de validez de nossa hipótese nas novas tendências e correntes históricas em voga hoje na arquitetura. 
Aparato

ISTITUTO ONIVERSITARIO

DI ARCHITETTURA

30 OSS TENEZIA

STITUT $\varnothing$ DI STORIA DELL'ARCHITETTURA

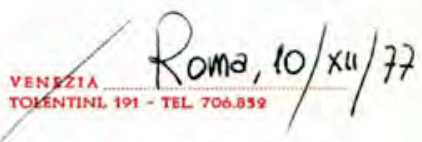

Caro Philippe,

ti risponolo immediatamante, questa volta. Fra ta e me c'è sempre lo "schermo-ombra" Idi_ au tu dai troppa importanza: l'odio-amore che vi legas ti spinge a valutore me attraverso di hin, a pui tu sbagli. Adesempio: io ti weve soritto che to matto piecere - l'aurei tuttora - che tul scrivessi l'introductiove a Projet etutopie,

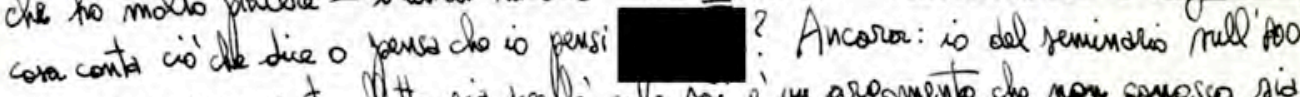

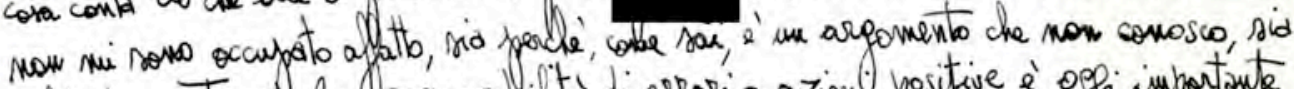
perché dare a Teysset la presponsobilita' di errorio a ziont positive è ogfi importante

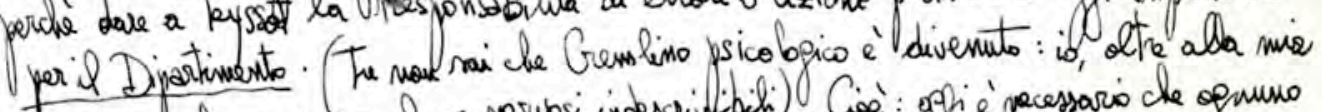

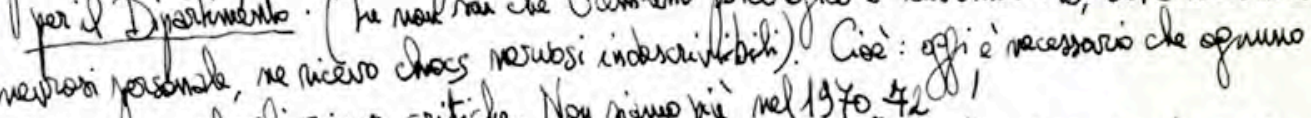

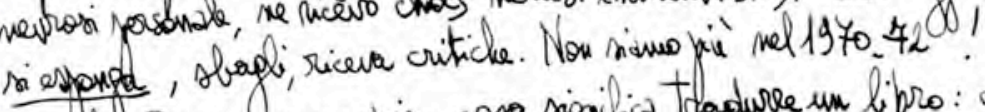
Fedo che Dunos non capice cosa significa tradurle un bibro: cercherò di intervervire,

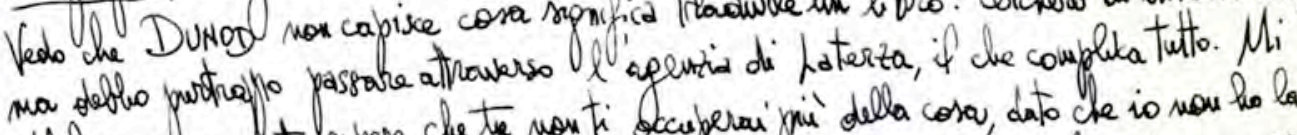

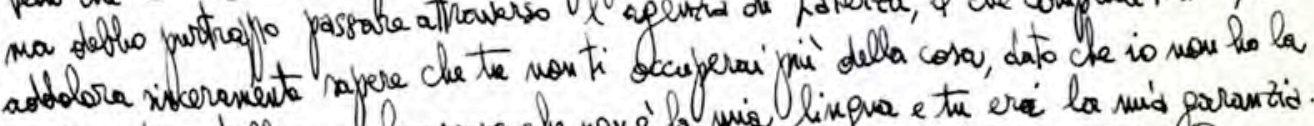

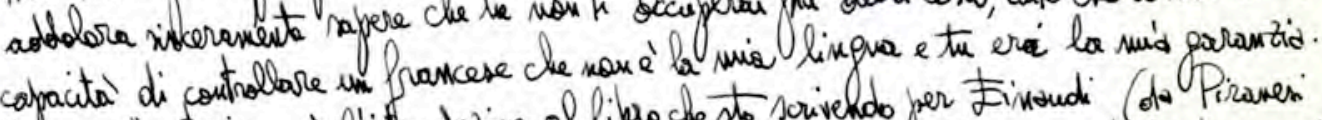

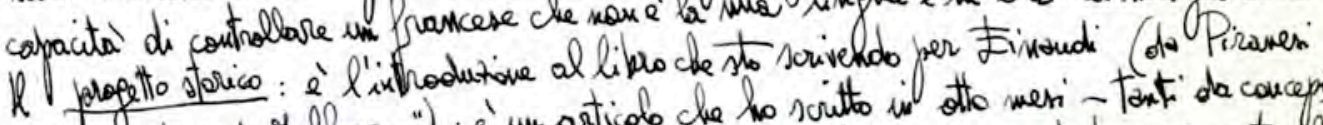
alle "cenotres de Yefferson"): e' un articalo che ho soutto in atto mes' - tant' de concepi

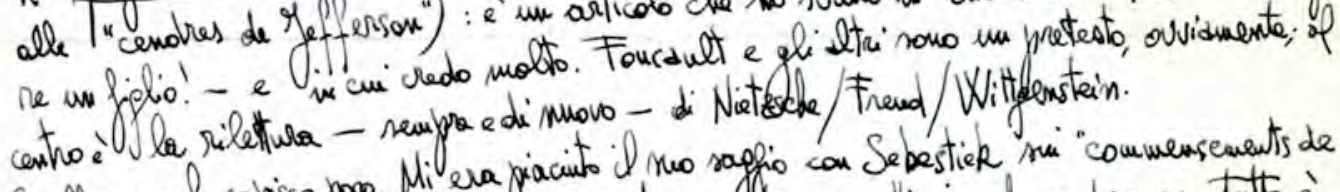

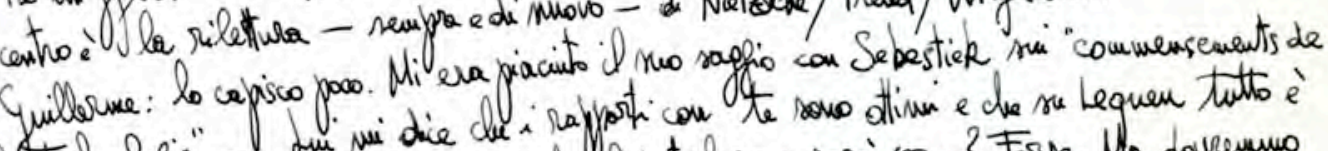

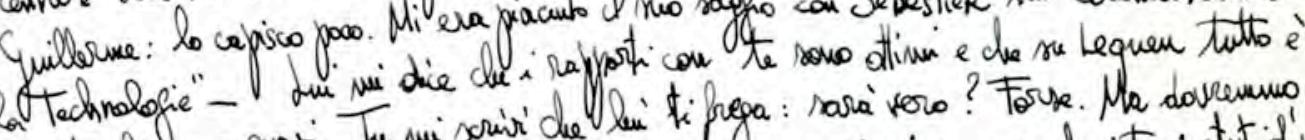

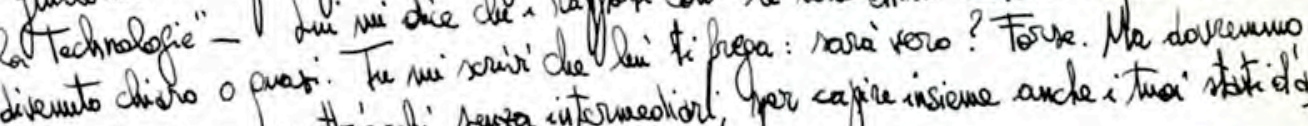

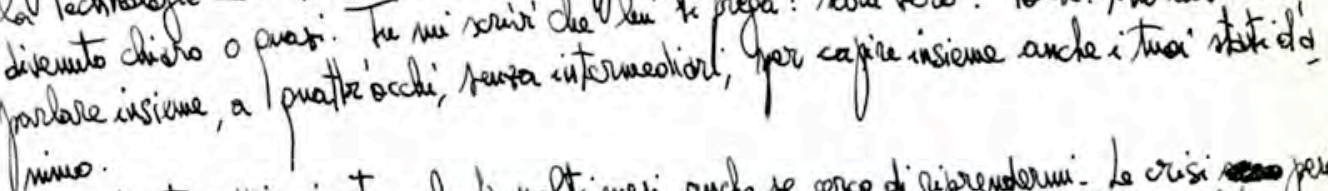

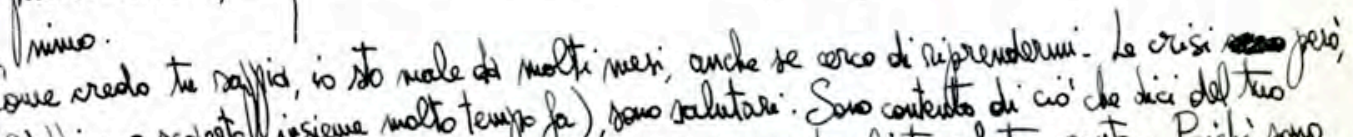

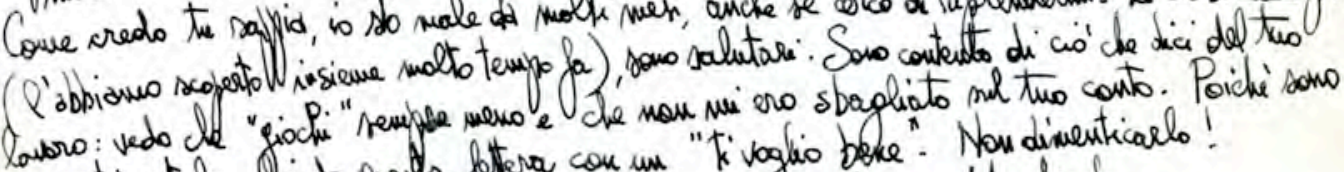
in sentriventale, chindo questa lettera con un "Fivoglio bene". Non dímenticarlo!

Correspondência entre Manfredo Tafuri e Philippe Duboü, 10/12/1977. 


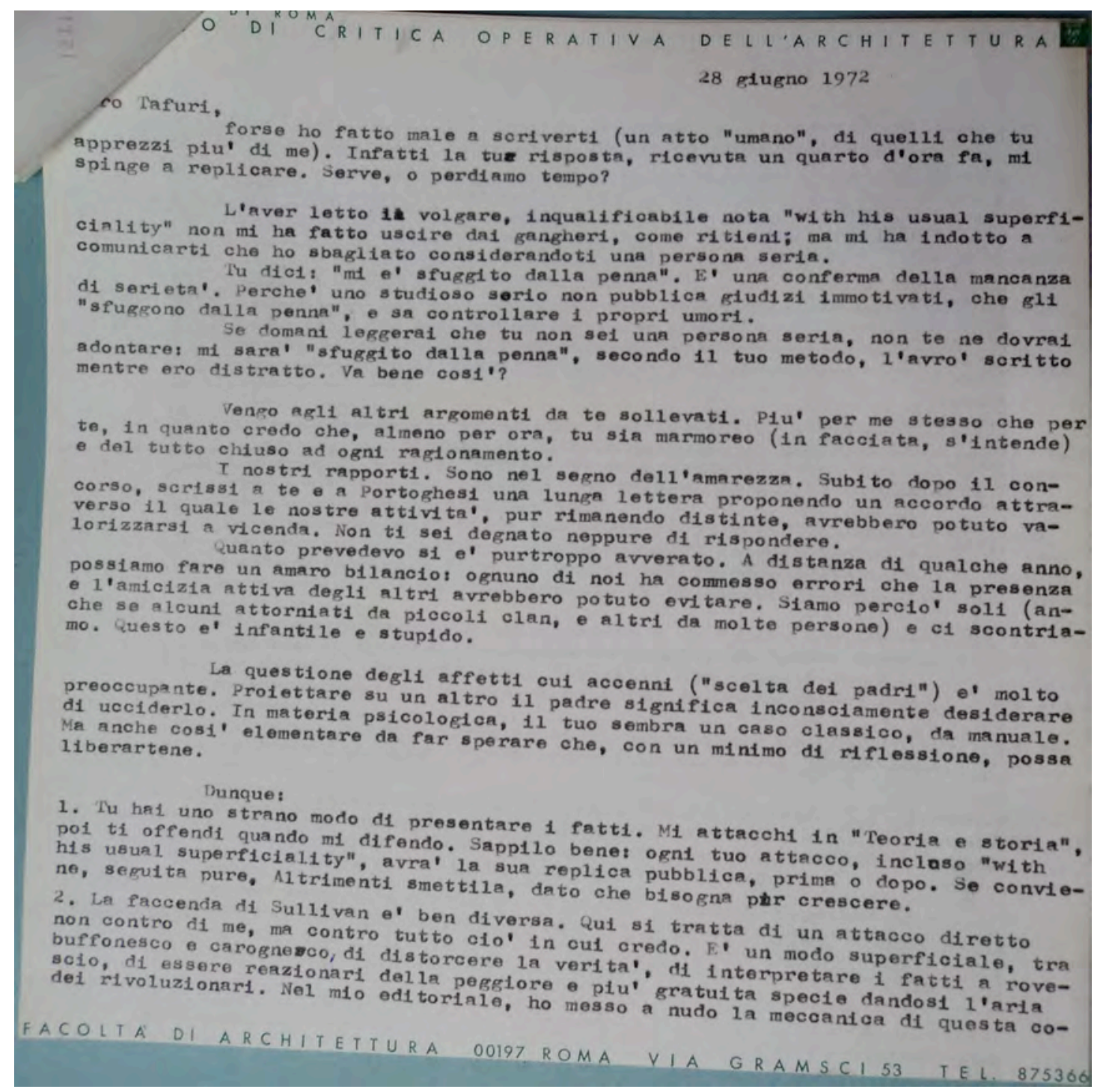

Carta de Bruno Zevi a Manfredo Tafuri, 28/06/1972. Página 01. 


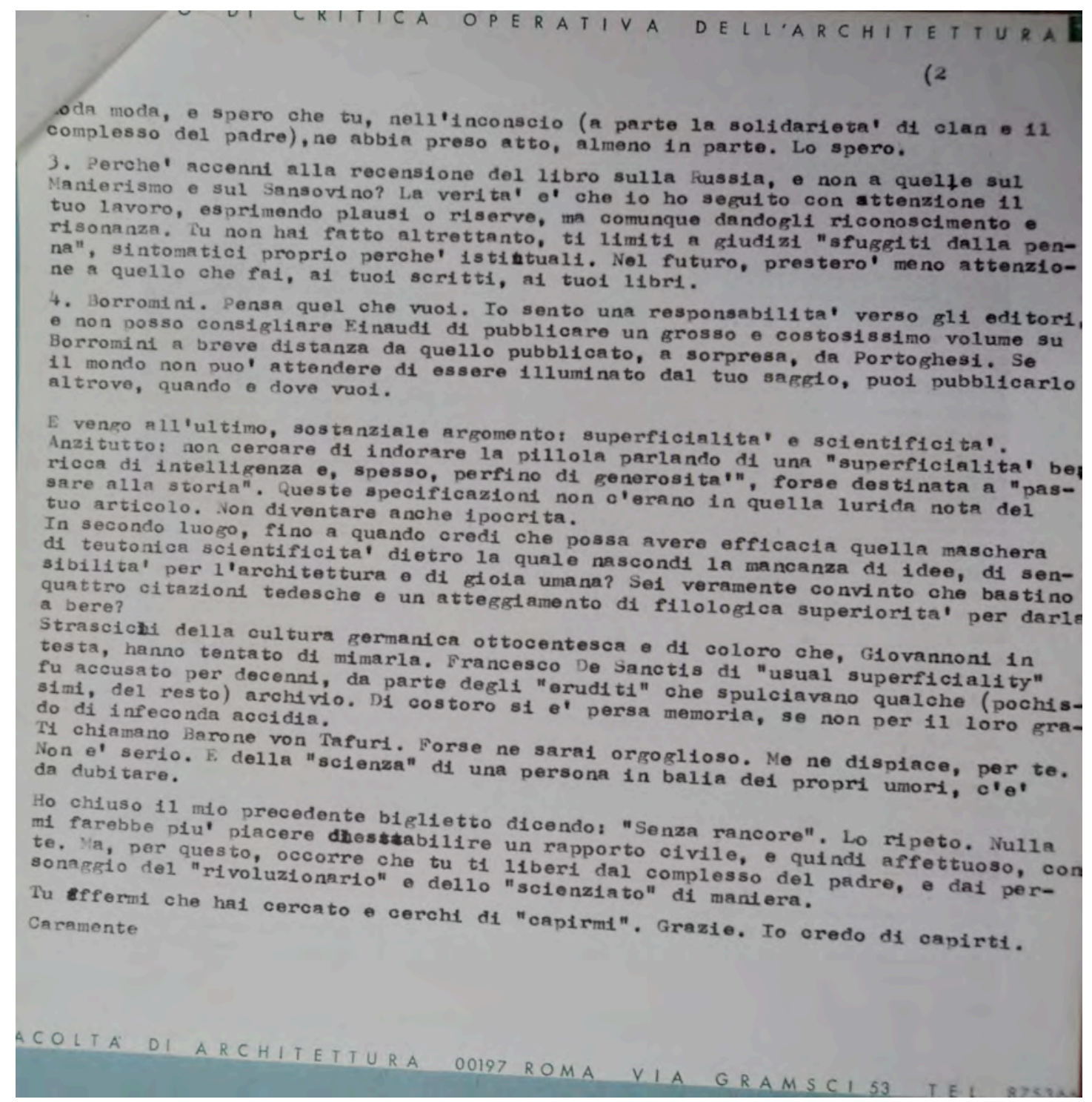

Carta de Bruno Zevi a Manfredo Tafuri, 28/06/1972. Página 02. 


\section{Dois projetos}

$\mathrm{Na}$ década de sessenta, Tafuri se consolida como intelectual. No princípio desse decênio o autor romano está ainda na graduação, dentro dos debates políticos que cresciam nas universidades italianas, ao mesmo tempo em que já se articulava dentro do meio da arquitetura, tendo colaborado algumas vezes com revistas como Casabella e L'Architettura, opinando acerca de questões do cenário profissional. No final, já estava bem estabelecido: professor ordinário em Veneza, colecionando admiradores e inimigos pelo livro "Teorias e história da arquitetura", ao mesmo tempo em que se inseria mais e mais no eixo veneziano de intelectuais de esquerda, culminando no texto "Por uma crítica da ideologia arquitetônica", de 1969, que definiria os termos da sua trajetória como historiador.

É certo que "Teorias e história da arquitetura", tanto quanto um marco para a compreensão geral da contribuição de Tafuri, é igualmente um testemunho final desta época incerta, na qual o autor ainda não tinha efetivamente tomado as suas mais conhecidas escolhas, como sua orientação crítica privilegiando a história em detrimento de outras áreas do conhecimento, seu rigor filológico ao invés da intuição sensitiva e da interdisciplinaridade, pautando-se pelo ganho político advindo de uma ampla abordagem de seus temas de pesquisa. Sobretudo, ali tem-se o memorial justificativo de sua mais marcante escolha feita na década, a de declínio da sua prática como arquiteto em favor da intelectual.

A escolha profissional por ser historiador de arquitetura poderia ser vista como um momento biográfico protocolar, de menor importância para os estudos sobre a obra de Tafuri. Entretanto, ela é importante para a compreensão da gênese de temas seminais que sempre o acompanharam, na medida em que muitos dos arquitetos e movimentos persistentemente citados nos seus textos foram igualmente importantes 
para a sua produção profissional. Le Corbusier, Louis Kahn, Ludovico Quaroni, entre outros, aparecem como referenciais tanto nesta curta experiência como arquiteto, como na longa estrada que viria a seguir como historiador. Ademais, o caráter das rupturas de Tafuri com a década de 60 aparece como uma provocação para que se compreenda melhor os termos da sua teoria feita na época em que ainda se debruçava sobre a prancheta. "A arquitetura do maneirismo no Cinquecento europeu" e "A arquitetura moderna no Japão", livros renegados na sua maturidade, demonstram como os anos de prática aparecem como tabus na construção que o autor fez de si nos anos posteriores. "Eu o deixei [o campo da arquitetura] para trás em 1962, uma longa história," ${ }^{26}$ disse Tafuri em 1976, numa entrevista a Françoise Very.

Apesar da declaração, depois deste ano ainda foi possível ver o nome de Tafuri nos créditos do escritório fundado com seus colegas em Roma, o "Studio AUA", assinando centros direcionais e outros programas. Em 1993, o historiador criou uma nova versão para a sua tomada de decisão, datada em 1964:

Em uma trágica noite eu estava desesperado porque teria de decidir entre prática e história. Lembro-me de estar suando, perambulando, senti-me doente, tive febre. De manhã, decidi, era isto! Desisti de todas as ferramentas da arquitetura e me determinei a dedicar-me inteiramente à bistória. Que tipo de história, não sabia, mas então sabia que deveria ser história. ${ }^{57}$

Longa noite, que durou uma década. Neste último depoimento, é interessante como o autor confessa o esprit do período, segundo o qual as suas decisões foram tomadas com mais ímpeto e menos clareza. Ao dizer que não sabia a história que faria, Tafuri remete ao cenário intelectual da época, no qual os debates todos corriam em torno de uma reformulação histórica da península, que recém formava a geração que havia passado a infância em suspenso durante a ascensão do fascismo, a guerra e a ocupação alemã. Tafuri era mais um neste período, engajado em diversas iniciativas

\footnotetext{
${ }^{56}$ Entrevista de Manfredo Tafuri concedida a Françoise Very. "I mercatti della cultura”, In: Casabella, n. 619, 620, 1995, p. 38.

57 "History as project", Op. cit., p. 30 e ss.
} 
em andamento na sua cidade natal, Roma. Vieri Quilici, colega de Tafuri neste período, falava sobre a euforia do período, no qual "existia um grande fermento que entretanto não correspondia exatamente a uma mudança geral da cultura, do costume. ${ }^{58,}$

Quilici faz este retrato amparando-se em Miriam Malfai, no texto "A ultrapassagem: os extraordinários anos do milagre econômico, 1958-63", no qual a autora descreve o contraste entre a penúria e temor da guerra e a prosperidade peninsular que veio nas décadas seguintes. "Se os adultos percebem [do milagre econômico], seja confusamente e com alguma preocupação, a mudança em andamento, eles, os jovens, vivem dentro dele com naturalidade e querem gozar imediatamente as oportunidades oferecidas: a música, o cinema, a Vespa." ${ }^{29}$

É seguro dizer que, apesar de menos otimista, o modo como Tafuri viveu estes tempos é marcado por este afã. A guerra nunca desvaneceu de sua memória, especialmente por ter sido perseguido durante o regime. Segundo Manuela Morresi, professora do IUAV e última companheira de Tafuri, o autor tinha a lembrança deste período como recorrente nas conversas privadas. "Para ele, era como se a guerra tivesse acontecido ontem, e não há muitos anos." ${ }^{\circ 0}$ Ao mesmo tempo, esta marca servia de ímpeto para uma vida intensa durante os anos sessenta, nos quais, de acordo com a professora - reforçando o coro de Quilici e Malfai - “os anos da reconstrução já tinham passado, e toda mudança parecia possível." ${ }^{61}$

Não se pode afirmar a partir deste depoimento que o autor tem seu ceticismo marcado por memórias de infância. Entretanto, pode-se retirar dele uma visão plausível de pano de fundo deste seu lançar-se, após os anos da reconstrução, a um amplo leque de atividades, tendo praticado a escultura, a pintura e entrado em contato com a obra de estrangeiros como Camus, Sartre, Heidegger e mergulhado nas teses de seus conterrâneos, como Croce, Paci e outros filósofos. A arquitetura neste momento

\footnotetext{
${ }^{58}$ Entrevista de Vieri Quilici concedida a Federico Rosa. In: ROSA, Federico. Progetto e critica dell'urbanistica moderna: I primi anni di attività di Manfredo Tafuri. Veneza: IUAV, tesi di laurea, 2003, p. 341.

${ }^{59}$ MALFAI, Miria. Il sorpasso: gli estraordinari anni del miracolo economico. Milão: Mondadori, 1997, p. 45.

${ }^{60}$ Depoimento de Manuela Morresi feito ao autor em 24 de novembro de 2010. Este depoimento é reforçado pela entrevista de Tafuri a Luisa Passerini, "History as Project", no qual ele detalha sua experiência nos subterrâneos romanos e sua fuga para Nápoles.

${ }^{61}$ Idem.
} 
é mais uma de suas pesquisas, com a qual ele entra em contato através do texto de Bruno Zevi, "História da arquitetura moderna", que, junto com os escritos de arte de Giulio Carlo Argan, começaram a direcionar o autor para esta atividade ${ }^{62}$.

Como a arquitetura toma o centro de seu interesse e em que medida esta se desdobra em uma vertente histórica não é tanto a pergunta que se pretende responder, na medida em que ela própria foi respondida pela atividade do autor como historiador nos anos seguintes à década de sessenta. O principal é: como o jovem Tafuri, arquiteto, teórico, historiador e político, lançou temas que “assombraram" os seus anos de maturidade?

Em 1959, é publicado ao final da edição 45 da revista L'Architettura um discreto manifesto de fundação da "Associação de estudantes e arquitetos de Roma”, assinado por uma série de alunos da Faculdade de Arquitetura Valle Giulia, da capital italiana. A intenção do documento era deixar clara a intenção deste novo coletivo de "reconectar-se, em termos históricos, às premissas morais, sociais e culturais que informam o Movimento Moderno”, descrito nas linhas anteriores como responsável por fazer evoluir a cultura arquitetônica, "por mais de meio século", "no esforço de aderir às exigências do homem moderno na sua sociedade." ${ }^{63}$

Essa posição tinha um caráter defensivo. Era generalizada a insatisfação dos jovens alunos da faculdade romana com os mandos e desmandos de seus professores, tidos nos depoimentos de Tafuri e de seus colegas como ainda ligados a ideias fascistas. No manifesto da Associação, o Movimento Moderno é colocado como resposta a uma situacão italiana: "hoje, quando seria razoável verificar em ação concreta os resultados críticos conquistados, assistimos no nosso país manifestações anti-históricas, evoluções reacionárias e injustificáveis renúncias." ${ }^{64}$

Em 1960, a Associação formula um ataque direto ao professor que mais representava os quadros de inspiração fascista na faculdade: Saverio Muratori. Muratori fora parceiro de diversos nomes da arquitetura italiana do período, inclusive promovendo edifícios habitacionais modernistas para a iniciativa "INA Casa". No seu curso de composição, entretanto, orientava seus alunos a desenharem igrejas com telhados, mercados com cornijas e óculos. As páginas de L'Architettura foram

\footnotetext{
62 "History as Project", Op. cit., p. 16.

63 “Associazione studenti e architetti”, In. L'Architettura cronache e storia, n. 45, 1959, p. 211.

${ }^{64}$ Idem, p. 211.
} 
ilustradas com os trabalhos dos alunos, recolhidos e expostos na faculdade com a “curadoria” de Tafuri e Giorgio Piccinato. A publicação abriu espaço para os alunos, nos quais a apreensão generalizada girava em torno do anacronismo e falta de "aderência histórica" das propostas do professor. Tafuri na sua fala formula uma crítica mais centrada na questão urbanística, que segundo o autor, para Muratori se resume a “algumas composições de eixos, algumas composições volumétricas e espaciais." 65

As postulações modernistas, para estes jovens estudantes, era o remédio necessário para que se colocasse a arquitetura nos debates da época. Na Valle Giulia, isto era agravado pela presença do fascismo, que regulava e excluía os debates da arquitetura com o presente. No bojo desta condição defensiva, Tafuri também lançou mão, com os seus colegas, de atitudes mais radicais, como a ocupação da faculdade, da qual foi um dos organizadores e lhe rendeu, desde o começo, fama de contestador. ${ }^{66}$

De todo modo, de sua formação, sobressaem-se estes dois aspectos: uma crença firme de que o modernismo poderia trazer um contraponto à condição italiana e um forte senso político da necessidade de unificação de pautas contra o inimigo comum: durante a faculdade, os ditos professores fascistas; contra a estagnação projetual na península.

No mesmo ano de 1960, Ernesto Nathan Rogers, editor da revista Casabella, publica um provocativo texto do engenheiro Luigi Cosenza acerca dos caminhos da profissão na Itália. O interlocutor do autor romano colocava que então "a prática e ensino de arquitetura não são mais um trabalho honesto." ${ }^{~} 67$ A crítica orbitava em torno do giro da área em torno de falsas questões, anacrônicas, que apareciam em

\footnotetext{
65 "Si accordano su un punto: è meglio il meretricio", In: L'Architettura cronache e storia, n. 57, 1960, p. 148. A relação entre Tafuri e Muratori, entretanto, é mais complexa e ultrapassa os anos sessenta. Em 1986, ao revisitar o período no seu itinerário sobre arquitetura italiana, o autor romano admite que "Indubitavelmente, a análise urbana como se desenvolveu na Itália dos anos sessenta em diante é tributária dos estudos muratorianos sobre Veneza e Roma. Aqueles estudos, por outro lado, moviam os interesses para a estrutura dos tecidos antigos, fazendo anacrônicos o debate sobre a 'preexistência' e dando diferente espessura ao tema dos centros históricos." TAFURI, Manfredo. Storia dell'architettura italiana, 1944-1985. Turim: Einaudi, 2002. p. 80. De fato, Muratori em seu estudo de Veneza antecipa já muitos dos temas tipológicos que Tafuri vai desenvolver sobre a cidade nos anos oitenta. "Desenvolver uma pesquisa histórica sobre um plano estrutural e nos limites intrinsecamente objetivos das próprias estruturas, significa não só fornecer uma documentação ausente de todo relativismo, mas também assinalar os limites e o endereço de um programa positivo de ação (...)" MURATORI, Saverio. Studi per una storia operante. Storia urbana di Venezia. Roma: Istituto poligrafico dello stato, 1959, p. 12. Um estudo mais aprofundado desta revisão crítica de Muratori não passa pelos temas da tese, mas atenta-se que se trata de uma história ainda por construir acerca do corpus de Tafuri.

${ }^{66}$ Cf. "Entrevista com Vieri Quilici". In: Op. cit., p. 337.

${ }^{67}$ COSENZA, Luigi. "Per un dibattito costruttivo", In: Casabella, n. 230, 1959, p. 3.
} 
momentos tensos como planos reguladores de cidades no sul, entre outras. Cosenza acena para a crise nas grandes cidades que aplacava a Itália, sobretudo pelo seu rápido crescimento durante o milagre econômico, o que colocava a profissão em um estado de transformação. A ordem do dia era, de fato, esta preocupação generalizada. O estudante Tafuri subscrevia-se ao posicionamento do engenheiro, deixando claro que somente "uma substancial unidade das forças culturais, profissionais e acadêmicas unidas por uma renovação da sociedade", poderiam convergir para uma "ação unitária" ${ }^{68}$.

Estas condições fizeram com que Tafuri se inserisse no campo da arquitetura romana como desdobramento de sua atividade no movimento estudantil, quando vários integrantes da Associação se juntaram para criar o "Studio AUA". A iniciativa coletiva assinava os projetos em conjunto e se lançava majoritariamente aos grandes concursos, nos quais competiam com seus mestres e professores, como Ludovico Quaroni, Leonardo Benevolo - e o próprio Saverio Muratori.

O escritório, pela sua formação e pela própria condição intensa em que viviam os jovens da península, era mais do que um simples projeto de negócio, mas um aparelho político pelo qual se formularia a tal ação unitária. $\mathrm{Na}$ realidade, a dissociação entre arquitetura e política que se tentava impor aos alunos durante os anos de faculdade era quase impossível de se realizar no cenário urbanístico da Itália no período. $\mathrm{O}$ crescimento das cidades no pós-guerra recaía nos arquitetos italianos como um duro fardo para se resolver, haja vista a constante preocupação dos peninsulares com a preservação de seu tecido histórico e sua escala, a ponto da própria metropolização parecer um problema, conforme dizia Carlo Aymonino no fechamento de um congresso:

Resta confirmada a dimensão italiana dos problemas que não alcançaram ainda os casos patológicos de muitos dos exemplos estrangeiros: a dimensão da metrópole não é ainda realizada em nenhuma zona da Itália e desta constatação se reafirma a possibilidade de realizar ainda

\footnotetext{
${ }^{68}$ TAFURI, Manfredo e TEODORI, Massimo. "Lettere di studenti”, In: Casabella, n. 241, 1960, p. 58.
} 


\section{hoje um salto real do nosso trabalho e de nossa intervenção. ${ }^{69}$}

A geração italiana anterior à de Tafuri recusava a linguagem racionalista das vanguardas européias, não só pelo elogio à experiência múltipla e densificante que eram as metrópoles, mas sobretudo pela ligação histórica e inesperada com que o vocabulário modernista foi utilizado na promoção grandiloquente do fascismo dentro da Itália. Desta forma, explicam-se algumas experiências de habitação social feitas pelas gestões de esquerda em Roma, como o "Quartiere Tiburtino", assinado por uma junta que ia desde Quaroni até Muratori, no qual o bairro era resolvido em uma linguagem híbrida, que congregava plantas enxutas como promovidas pelos movimentos alemães do entreguerras, ao mesmo tempo em que fazia uma implantação pouco concisa e citava abertamente motivos provincianos, como telhados inclinados e pequenas janelas.

Os integrantes do "Studio AUA" estabeleceram-se em um momento no qual os arquitetos italianos, malgrado alguma desarticulação, encontravam-se já menos contidos com a herança do racionalismo italiano. Para o enfrentamento da questão das cidades, os arquitetos da península procuravam inspirações no debate internacional em andamento no resto da Europa, e além. Existia, da parte de arquitetos mais velhos e de uma ampla fração de jovens profissionais, uma vontade de trazer para a Itália a experiência dos grandes centros comerciais no centro de Filadélfia, feito por Louis Kahn, as megaestruturas de Tóquio, de Kenzo Tange e, no limite, as fantasias tecnológicas dos britânicos do Archigram. A grandiosidade da escala de intervenção, o amparo em uma tecnologia de ponta, as chamadas megaestruturas, eram os pontos comuns que, segundo Tafuri em 1966, inauguraram uma "nova internacional da utopia." $^{70}$

"A utopia toma pé nas situações de crise ou de transição linguística, como esforço teso para uma busca claramente direcionada a queimar etapas no difícil

\footnotetext{
${ }^{69}$ AYMONINO, Carlo. "Conclusioni sulle relazioni dei gruppi di ricerca", In: La Città territorio: Un esperimento didattico sul Centro Direzionale di Centocelle in Roma. Roma: Leonardo Da Vinci Editrice, 1964, p. 108.

${ }^{70}$ TAFURI, Manfredo. "La nuova dimensione urbana e la funzione dell'utopia”, In: L'Architettura cronache e storia, vol. 124, 1966, p. 680.
} 
caminho de se criar uma nova linguagem." ${ }^{71}$ Desta maneira, desprender-se-iam do compromisso com o presente. Analisa a contribuição destas intervenções como discursos, colaboradores na formulação de novas diretrizes para o planejamento das grandes cidades.

Conforme Tafuri, estes desenhos urbanísticos se amparam nos conceitos de flexibilidade e mobilidade: não são soluções fechadas para comportar de modo estrito os habitantes da cidade. Consideram um crescimento da cidade que ultrapassará a demanda por eles prevista inicialmente. Nos projetos de Tange, existem esquemas de crescimento linear de seus módulos em períodos "qüinqüenais". As estruturas primárias onde se conectariam unidades habitacionais na Plug-in City do Archigram, ou os módulos flutuantes de Tange, são maneiras de pela edificação viabilizar uma direta previsão de contenção racional e eficiente das populações nestas novas cidades.

Como crítico, estas propostas serão lidas por Tafuri menos como uma solução concreta do que imagética. Servem como expressão de uma alternativa nova, outra à cidade existente, onde os problemas contemporâneos serão enfrentados. "Os organismos polifuncionais, escreve Tafuri, tendem a se posicionar como objetos absolutos no seu caráter unitário, isolados (...) pressupondo uma percepção imediata e global seja das suas relações internas ou externas (com a cidade existente, com o território)."72

Entretanto, dentro do "Studio AUA", a virtualidade de execução destas megaestruturas era levada a sério, sobretudo pela vantagem de aceitar com pujança o desafio do crescimento urbano e acertar a escala em que se deve intervir nas cidades: a paisagem, os edifícios existentes, o centro histórico: todos devem ser articulados por estas estruturas. Ao binômio centro e periferia, sucede-se uma relação mais ampla, onde todo o território estaria envolvido. A cidade território não seria uma cidade encerrada em si: considerará as cidades próximas, a geografia de toda a região onde se localiza. As vias de alta velocidade, quarteirões, bairros, centro histórico, montanhas e rios: todos teriam seus usos recriados diante da absorção do crescimento das cidades pelas novas estruturas.

\footnotetext{
${ }^{71}$ Idem, p. 680.

${ }^{72}$ TAFURI, Manfredo. "La nuova dimensione e la funzione dell'utopia”, Op. cit. p. 681. Grifo de Tafuri.
} 
$\mathrm{Na}$ Itália, a virtuose tecnológica encontra as preocupações supracitadas da interferência no tecido histórico. A articulação da cidade industrial com os tecidos históricos são o ponto de inflexão problemático das megaestruturas na Itália.

Nos diagnósticos das cidades em rápido crescimento, as proposições sempre partem do incômodo em intervir no passado anterior à industrialização e ao rápido crescimento das cidades. Aymonino chega a separar estes dois séculos próximos do resto da história das cidades italianas. "Não ignorar a experiência que foi se acumulando durante quase dois séculos na cidade capitalista significaria talvez isso: aceitar a ruptura da forma urbana como forma fisicamente reconhecível enquanto realizada dentro de um desenho constante e unitário (o perímetro das muralhas, o enorme volume do Duomo, a torre da prefeitura etc.) para elaborar uma identificação da forma urbana de tipo distinto, enquanto organizada em torno de uma distinta hierarquia das destinações de uso das cidades e do território."73

Aymonino é um arquiteto cético acerca desta cisão. Se a organização das cidades na era industrial deve ser apreendida como histórica, nada em sua prosa é complacente com o rápido - e descontrolado - crescimento das cidades sob esta matriz.

O temor pelas metrópoles como ruptura com o passado, como fenômeno urbano diluente da forma das antigas cidades é importante para Tafuri arquiteto. Ao escrever sobre centros históricos, o arquiteto parte da ideia de um modo de se ver as cidades que as descaracterizou, e trabalha com a urgência de se dar um novo significado para o tecido histórico - separando a história recente da mais antiga. Sua argumentação, como vimos, é crítica acerca das New Towns ou outras manifestações por demais destacadas dos fenômenos urbanos, também tem fundamento contrário a uma total aceitação da metrópole, vista por Tafuri como "violentamente contraposta à ideia de território" ${ }^{74}$, na medida em que reproduz as relações de um centro e sua periferia, e causaria um desequilíbrio urbanístico com o restante do país.

O "Studio AUA" entra nestas questões formulando propostas de "centros direcionais" desenhados à maneira das megaestruturas. Articulando os princípios da

\footnotetext{
${ }^{73}$ AYMONINO, Carlo. Origini e sviluppo della città moderna. Tradução para o espanhol: Orígenes y desarrollo de la ciudad moderna. Barcelona: Gustavo Gili, 1972. p. 89.

${ }^{74}$ TAFURI, Manfredo. "Il problema dei centri storici all'interno della nuova dimensione citadina", $O p$. cit. p. 28.
} 
cidade-território com o vocabulário de inspiração modernista típico das experiências de Tange, Kahn e Le Corbusier, o escritório obteve sucesso na sua inserção, vencendo logo nos primeiros anos de fundação o concurso para o centro cultural, comercial e recreativo de Fano. A escala do projeto era menor, resolvida como uma praça interna que integrava diversos volumes em uma linguagem vagamente lecorbusiana que resolvia a circulação com corredores internos e externos. $\mathrm{O}$ escritório recebe menção honrosa no concurso para o centro direcional de Turim, no coração da cidade. A proposta vencedora era da equipe de Ludovico Quadroni, um conjunto de arranhacéus compunha com lâminas baixas que deixavam o térreo livre, em uma versão italiana do Plan Voisin de Le Corbusier. O "Studio AUA", por outro lado, propôs uma inserção mais literal no tecido urbano, criando um complexo que girava em torno de duas longas lâminas com uma pista de alta velocidade no terceiro andar que se ligaria a vários bairros da cidade. No entorno desta grande estrutura, teriam pequenas torres eram espalhadas nas periferias, cuja presença é auxiliar à "espinha dorsal na qual são reunidos e integrados todos os elementos constitutivos do C.D.” 75

O projeto do Estúdio tinha uma implantação muito legível no tecido da cidade, sendo a planta de situação muito eloquente. No corte transversal das lâminas, os arquitetos mostram maiores detalhes do que seria a escala menor da intervenção. Elas são resolvidas em varandas que se abrem para a autoestrada elevada - dez metros sobre o nível do térreo, no qual se pode circular, por carro ou a pé, por cima de Turim, descendo escadas e alcançando alguns programas que ficam entre a autopista e o térreo da cidade.

A integração entre essas duas cotas de circulação é francamente problemática: escadarias com quatro lances e rampas muito íngremes conectam a cidade ao programa semipúblico elevado, e a transposição do complexo através do nível da autopista é praticamente impossível pelo fluxo ininterrupto de carros. Pouco funcional nas minúcias, o projeto do Estúdio privilegiava claramente a força urbana - ou imagética - da intervenção em Turim.

Tafuri, em meio a esta equipe, tinha claramente o papel de teórico, como depôs Quilici, dizendo que "a sua contribuição era mais geral, de controle crítico do

\footnotetext{
75 “Concorso per il centro direzionale di Torino”. In: Casabella, n. 278, 1963, p. 38.
} 
processo de decisões" ${ }^{\text {76 }}$. Giorgio Piccinato, outro integrante do Estúdio, fala também acerca deste caráter, de que "os projetistas [do Estúdio] eram outros, ele, por sua vez, teorizava o que se fazia." 77

Piccinato deixa clara a peculiar posição de Tafuri no Estúdio, como uma figura cuja presença no coletivo era tensionada com sua carreira particular. "Manfredo tomou rapidamente um caminho individual. Nós escrevíamos como se fossêmos um coletivo, ele começou rapidamente a personalizar a sua escrita." ${ }^{78}$

Mesmo quando participa de grandes publicações acerca das cidades território, Tafuri cria linhas de argumentação particulares, que são menos ligadas aos textos de arquitetos do período. $\mathrm{O}$ autor romano buscará na história das vanguardas o amparo para a prática do Estúdio e dos arquitetos de sua geração. Pondera as afinidades destes com os projetos urbanísticos de Bruno Taut, suas cidades-jardim articuladas em redes de comunicação: "modelos espaciais" que seriam expansíveis pela cidade. Considera também as New Towns inglesas e outros procedimentos que partem da fundação de pequenas cidades em torno das capitais. Tais referências são todas viáveis, fora da esfera da utopia onde o arquiteto italiano inseria os desenhos de Tange e Kahn, malgrado sua tomada como referência. Ponto negativo comum entre elas, conforme Tafuri, é o abandono do conceito de "procedimento da fenomenologia urbana". Nestas intervenções existe antes uma intenção de articulação do que de interferência direta no tecido existente. Assim, como uma justaposição de intervenções, verifica-se uma cisão entre o presente e o passado já constituído.

"O exorcismo total da mobilidade urbana e a sua previsão através de estruturas direcionais que polemizam, com seu declarado arcaísmo, nos confrontos de seu próprio inserir-se como ilhas, como objetos estranhos, na dinâmica da cidade (onde, se se quiser, a referência aos modos compositivos típicos da pop art podem ser reencontrados)." ${ }^{\text {"9 }}$

Tal justaposição cria, ao longo do tempo, uma competição de lógicas urbanas: o crescimento das megaestruturas, com suas retículas geométricas se imporiam aos fenômenos urbanos já constituídos. Principalmente, o italiano se refere aos centros e

\footnotetext{
76 “Entrevista com Vieri Quilici”. Op. cit., p. 347.

${ }^{77}$ Depoimento de Giorgio Piccinato feito ao autor em 16 de novembro de 2013.

${ }^{78}$ Idem.

${ }^{79}$ TAFURI, Manfredo. "Il problema dei centri storici all'interno della nuova dimensione citadina", $O p$. cit. p. 682. Grifos de Tafuri.
} 
bairros históricos, a transformação de seus usos com as mudanças de épocas etc. Tanto a cidade histórica e os novos projetos consideram o desenvolvimento no tempo: nem o antigo nem o novo são estáticos nestes projetos. Uma ruptura entre passado e presente é explicitada.

Nos meandros desse descompasso histórico era onde Tafuri estava mais solitário dentro do Estúdio. Para ele, as propostas de megaestruturas em geral certamente incluindo aquelas que realizava - traziam como grande contribuição a construção de uma "cidade de tendência imagética". Os módulos e componentes industriais criam objetos fechados na paisagem, sugerem e planejam a sua reprodução. Entretanto, essa postura perde força ao se desconectar do tempo dos fenômenos urbanos. Constituindo-se como processo alheio, a forma urbana não pode ser determinada pela arquitetura de megaestruturas. "Não é portanto um acaso que os projetos que estamos tratando assumam assim mesmo o aspecto de um paradoxo de sabor niilista; na realidade, com sua aparente ênfase figurativa eles destroem os conceitos de forma urbana, arquitetura, mobilidade e disponibilidade de organização territorial." ${ }^{\prime 0}$

Tais considerações aparecem na ata de um congresso acerca das cidades território feito em 1964, quando Tafuri está perto de tomar sua decisão final de abandonar o projeto. "Diante das tarefas que o empenho construtivo do arquiteto enfrenta somente com o ato de esperança advindo de sua vontade de projetar, a ambiguidade mesma, para ser aceitável, deve traduzir-se em valor comunicativo, em estrutura semântica, indicação figurativa em si fechada." ${ }^{11}$

Esta postura é colocada como intermediária a uma recuperação do poder de intervenção no presente, como a conclusão de seu texto determina:

Entre uma realidade todavia que não parece permitir ilusóes ou esperanças não acompanhadas da dramática vontade de resistência e evasão do tormentoso sonho cheio de simbolos, próprio das utopias presentes, a arquitetura moderna poderá de novo encontrar o seu

\footnotetext{
${ }^{80}$ Idem, p. 683.

${ }^{81}$ Idem, p. 683. Grifos de Tafuri.
} 
percurso positivo com um impiedoso ato crítico que se reconduza à matriz primeira do ato mesmo de projeto: que é, desde sempre, construção da realidade feita pelos homens do presente, como contribuição à secular busca do senso da bistória. $^{82}$

As utopias anti-históricas oferecem a resistência necessária para a recuperação do percurso positivo da arquitetura moderna. Na retórica destes projetos, Tafuri vê um modo de enfrentamento das cidades capaz de alcançar novos conteúdos, atualizar o ímpeto moderno de estabelecer novas categorias para novos problemas na cidade. A leitura de Tafuri dos projetos de Tange e Kahn os colocam como retomada dos dilemas históricos enfrentados pelos arquitetos do princípio do século XX: daí as referências ao Expressionismo e à Pop Art presentes no texto. Remontando à história das artes de vanguarda, Tafuri procura contribuir para o debate acerca das cidades grandes na década de sessenta, vendo ali uma continuação do problema histórico do lugar da arquitetura utópica no urbanismo.

Tais ponderações pessoais tiveram um efeito no jovem Tafuri, na ocasião do concurso para o Hospital Civil em Veneza, em 1963. O concurso previa um extenso programa que seria posicionado dentro do tecido insular da cidade, próximo à chegada da linha de trem que a conecta com o continente. O memorial descritivo do projeto se ampara em um modelo francês de caracterização da escala urbana que teria o hospital de acordo com as requisições do concurso. Nisto, o Estúdio conclui que teria de ser um "hospital divisional", que seria maior do que uma estrutura "local", podendo atender a até 300 mil habitantes. Considerando-se que até hoje a população da Veneza insular não alcançou esta marca, o hospital serviria muito mais do que à população da cidade. Em alguns croquis, chegou-se a propor uma ponte própria que ligasse o complexo até o continente, para dinamizar sua presença territorial. Duas grandes estruturas são posicionadas no perímetro da gleba, resultando em um espaço central com programas de dois a três andares que desenham uma grande esplanada de chegada, como um Campo veneziano, sucedendo-se a ele pequenos pátios internos às

\footnotetext{
${ }^{82}$ Idem, p. 683.
} 
alas. Nesta chegada está o ambulatório, de onde se partem para as alas de tratamento. As duas lâminas têm cinco andares escalonados, criando varandas para banho de sol dos pacientes internados.

Neste projeto, extenso e complexo na articulação dos programas, o corte transversal revela o dinamismo dos sistemas, com escadarias acompanhando a defasagem das varandas para se chegar nas diferentes alas com rapidez. Os croquis mostram como a construção em cinco andares - que fere o "gabarito" dos palazzi venezianos - é suavizada no encontro com as vielas da cidade pela solução das varandas. $\mathrm{Na}$ parte onde as lâminas apresentam sua altura máxima, o prédio já está voltado para o Mar Adriático, desenhando uma fachada da cidade de Veneza, para quem a vê do continente. As inserções em fotografias e croquis apresentados no concurso reforçam esta "vista de fora", deixando clara a vontade de contraste que o Estúdio gostaria com este ângulo: marcar a escala territorial do hospital dentro da região do Vêneto, em harmonia com as vielas e praças de Veneza.

Assim como Turim, a intervenção tinha a intenção de fazer uma interface de escalas. O problema é a condição de Veneza como uma cidade praticamente íntegra na sua forma urbana. Ainda que o terreno estivesse perto da ala mais recente da cidade, o hospital do "Studio AUA" teria certamente um impacto na paisagem que poderia realmente resultar em "tendência imagética". A questão repousava, então, no quão desejável seria esta transformação. Veneza não tem um centro histórico, os parâmetros de intervenção formulados pelo Estúdio entram abertamente em crise, reforçados pelo contraste insolúvel que o projeto desta dimensão chega na cidade dos canais.

Tafuri nunca se manifestou sobre este projeto. Segundo Giorgio Piccinato, seu colega estava, como de costume, afastado das idiossincrasias projetuais, tendo colaborado na produção de desenhos nos dias que antecediam a entrega ${ }^{83}$.

Em “Teorias e história da arquitetura”, no entanto, algumas páginas são preenchidas com a análise do projeto feito por Le Corbusier, fora do contexto do concurso, para o mesmo hospital, dois anos depois, em 1965. O arquiteto suíço ultrapassa os limite da gleba, fazendo um edifício espalhado pelo tecido urbano, criando pátios internos, emulando com um vocabulário moderno as tipologias típicas

\footnotetext{
${ }^{83}$ Depoimento de Giorgio Piccinato.
} 
da cidade de Veneza. As estruturas modulares pousam sobre pilotis pelos canais ou se assentam em plataformas flutuantes, pontes ligam alguns complexos e o espalhamento dos setores mescla o prédio no tecido.

O diálogo entre as duas estruturas [o hospital e a cidade] é encarado ao nível dos respectivos organismos, acentuando, no novo hospital, a continuidade $e$ a serialidade dos vários núcleos. Portanto, o ambiente específico é sujeito a uma reorganização imposta pela articulada máquina hospitalar. Por sua vez, a estrutura urbana assume um novo carácter de acabamento devido à clarificação critica que a obra de Le Corbusier consegue, requalificando uma franja ainda inacabada. ${ }^{84}$

Os "novos significados" aparecem na pequena escala, no desenho desta parte da cidade aos modos de uma Fondamenta. O caráter desta relação entre tempos, de acordo com a leitura de Tafuri, ampara-se na questão tecnológica pela modulação industrial requerida para a construção das alas do hospital. Entretanto, diferentemente das megaestruturas, o seu contraste com o tecido histórico tem uma presença maior na materialidade das peças industriais do que no contraste de escalas. Aquela megaestrutura discreta de Le Corbusier tinha força expressiva similar aos materiais brutos em contraste com industrializados feitos pelo arquiteto suíço no capitólio de Chandigarh, que chamavam a atenção de Tafuri em 1964, quando ainda era professor assistente.

Estas considerações mostram a preocupação do jovem historiador com uma escala menor, mais detalhada de estudos do que aquela dos grandes centros direcionais que de fato interessavam e davam coesão coletiva ao "Studio AUA". Coerentemente, a atividade de Tafuri como arquiteto teve apenas um capítulo no qual ele esteve à frente

\footnotetext{
${ }^{84}$ TAFURI, Manfredo. Teorie e storia dell'architettura, Op. cit. p. 103 e ss. Grifo do autor.
} 
de um projeto completo construído, no papel de coordenador geral, em uma iniciativa de escala menor, um prédio habitacional em Latina ${ }^{85}$.

O prédio possui onze pavimentos, cujas unidades são distribuídas em tipologias duplex. A planta e o vocabulário construtivo à maneira de caixotes empilhados, com caixilhos recuados e empenas cegas, possuem grande semelhança com a Unité d'habitation desenhada por Le Corbusier ao final dos anos quarenta, que teve um protótipo inaugurado em 1952 em Marselha. O projeto de Tafuri não tinha circunstâncias tão livres como as do arquiteto suíço, como ausência de lote ou regulações legislativas. Inserindo-se em um terreno de esquina, Tafuri preferiu defasar as unidades em planta, criando a impressão de uma sucessão de edifícios, ao invés de criar um plano contínuo na paisagem da pequena cidade italiana.

Ao publicar este projeto na Casabella, Tafuri participou de um debate com a 'nova geração' de arquitetos romanos da qual fazia parte pelo “Studio AUA”. Ao lado de sua fala, a revista publica o edifício de Latina e um tipologicamente símile assinado pelo Estúdio, em Bolonha, do qual não se tem informação da participação do historiador. Tafuri procura dar um tom de 'retomada crítica' do movimento moderno, concentrando seu argumento sobre dois pontos específicos: o primeiro era relativizando a possibilidade de uma arquitetura total que unificasse os métodos de escalas distintas, como design e urbanismo, em um modus igual de operação, o que, segundo ele deveria ser revisto, diante de tantos novos desafios após as vanguardas. $\mathrm{O}$ segundo é uma consideração acerca das vinculações políticas dos mestres do movimento moderno, sobretudo, Gropius e Le Corbusier. Segundo o autor romano, “o engajamento político [de Gropius e Le Corbusier] era de certo modo supérfluo, dado que o seu empenho artístico reassumia a batalha ideológica." ${ }^{\$ 6}$

A atividade do arquiteto precisaria, segundo o jovem Tafuri, ser feita dentro dos termos de um posicionamento. A sua fala transpira contradições, quando

\footnotetext{
${ }^{85} \mathrm{O}$ crédito de coordenador do projeto não aparece separado do corpo da equipe nas fichas técnicas de projetos do "Studio AUA" publicadas na Casabella. Ampara-se nos depoimentos de Vieri Quilici: Lembro-me que Tafuri realizou um projeto sozinho, ou melhor, não, ao menos dois pois um era um Plano Regulador (...). Um deles é um edifício em Latina, foi publicado e existe ainda", "Entrevista com Vieri Quilici", Op. cit., p. 347; e no testemunho de Giorgio Piccinato, "um dos primeiros projetos que assinamos [Piccinato e Tafuri] foi uma espécie de Unité d'habitation (...) em Latina...”. Depoimento de Giorgio Piccinato.

${ }^{86}$ TAFURI, Manfredo. “Progetti di architetti romani”, In. Casabella, n. 289, 1964, p. 10.
} 
completa dizendo-se muito crítico daqueles que insistem em se lançar para além dos limites da prática:

A transgressão dos arquitetos aos âmbitos que não lhe competem assume atualmente um significado diferente daquele que lhe era próprio dos anos 50: ali se tratava de empurrar para a unidade da cultura, para a introduçẫo do conceito de planificação; hoje se trata de uma perigosa ilusão que confirma, quando não coincide, com a tecnocracia $e$ superficialidade. ${ }^{87}$

Pode-se ler esta passagem como um eco passado de "Teorias e história da arquitetura", mas o interesse é vê-la publicada ao lado dos desenhos do autor que deliberadamente citavam a Unité d'babitation, um projeto de clara proposição unificante de escalas e ampliação do campo da arquitetura. As divisões se aprofundam se se tem em conta as opiniões que Tafuri professava na faculdade sobre a Unité. Como assistente do curso de composição de Ludovico Quaroni, o autor romano ministrava uma grande aula sobre o autor suíço, no encerramento do semestre, dizendo que "a obra lecorbuseana, de fato, no inteiro arco percorrido por ela, parece superar continuamente as contradições e impasses que verificamos nas lições precedentes..." 88

Entretanto, a Unité não era vista como progressista neste 'grande arco'. Antes, o edifício habitacional, "como definição total e absoluta da cidade, é um passo atrás acerca das experiências pré-guerra, talvez devido a um ato de realismo contingencial." 89

Tafuri descredenciava a Unité sobretudo pela sua posição de 'modelo'. Preferia as monumentalidades livres que o suíço desenhou em Chandigarh e Ronchamp. Se pensava assim, por quê, ao projetar um edifício habitacional da pequena cidade de Latina, preferiu o uso de uma linguagem prototípica, das peças industriais, dos

\footnotetext{
${ }^{87}$ Idem, p.10.

${ }^{88}$ TAFURI, Manfredo. L'architettura moderna alla luce dei problemi attuali,Op. cit. p. 39.

${ }^{89}$ Idem, p.39.
} 
módulos encaixados, típicos da pesquisa tecnológica que Le Corbusier empreendia em seus estudos para sua cidade desenhada pelas Unités?

Não é surpreendente o descompasso entre Tafuri arquiteto e crítico, pois tais tensões desaguam cristalinas em "Teorias e história da arquitetura". Nesta obra seminal, seja pela sua prosa aos modos de postulação teórica ou seja pela vontade de emancipação de seu autor, a distinção de atividades é defendida por um viés político, como se não houvesse possibilidade de conivência entre o crítico e o arquiteto, na medida em que é necessário total destacamento da conjuntura para que se possa ver para além desta. Entretanto, ler a década de '60 na carreira de Tafuri tendo como ponto fulcral somente esta obra leva-se a excluir um traço oculto que está bem marcado nesta oposição entre o historiador romano e o arquiteto, no que concernia Le Corbusier: a arquitetura e a teoria de Tafuri divergiam nos seus posicionamentos estéticos: ao mesmo tempo em que era lícito estudar a singeleza monumental de Chandigarh como um "sinal da vontade do homem de alcançar sua auto consciência" em detrimento de seus neorrealismos, era igualmente apropriado - ou necessário mergulhar na conjuntura das cidades italianas e formular com pragmatismo as peças para o seu redesenho. Assim, Tafuri participa amplamente de desenhos não tão poéticos para as franjas de Veneza, privilegiando a representação de uma escala territorial na ilha, com seu hospital ou - trabalhando mais próximo na solução do edifício, como em Latina - desenhando deliberadamente uma sucessão de escalas industriais para resolver a questão habitacional em Latina de um modo harmônico com a escala do entorno, utilizando componentes industriais suavizados pela defasagem das linhas de apartamentos.

Esta querela interna é resultado do conflito entre múltiplas filiações intelectuais que interessavam o jovem Tafuri. Diante da complexidade de relação entre obra projetada e escrita no período, não basta resumir tais dilemas a uma preferência que sempre esteve ali pela história, como o próprio autor gostaria de atestar no seu último depoimento à Passerini: "Afinal, eles [arquitetos do "Studio AUA"] queriam se tornar arquitetos para mudar honestamente a sociedade. Por outro lado, eu não estava interessado na prática de arquitetura porque ela não estava no centro de meus interesses." 90

\footnotetext{
90 "History as Project", Op. cit.p. 29.
} 
Se tivermos em conta os capítulos seguintes na carreira de Tafuri, a afirmação parece plenamente válida, mas como endossá-la diante das participações, manifestos e engajamentos diretos nas questões de cidade e projetos que marcavam a sua carreira? Malgrado sua láurea tenha sido conquistada por um trabalho teórico - e não em projeto - e o constante interesse nos procedimentos filológicos de história, é mais preciso ver a divisão pessoal do autor romano em termos menos assertivos, como colocou, com maior precisão, Cohen:

$A$ participação de Tafuri em revistas como 'Casabella-Continuità', de um lado, e revistas de bistória da arte romanas relativamente acadêmicas marcam dois pontos de seu trabalho como bistoriador: De um lado a intervenção em nome do conhecimento bistórico na critica ideológica da produção arquitetônica, na qual ela era intermediária de um discurso alusivo e oracular. Por outro, a contribuição ao trabalho cumulativo dos historiadores de arte para interpretaçôes provocantes de materiais frequentemente já conhecidos mas deixados de lado de toda perspectiva crítica. ${ }^{91}$

As esquerdas italianas do período, de um modo geral, tinham como base comum a vontade de se organizar em torno das possibilidades efetivas de transformação radical dentro de uma Europa renovada em sua relação com o capitalismo após a Segunda Guerra. Existia uma insatisfação geral com os termos soviéticos de expansão do capitalismo, ao mesmo tempo em que já estava clara a fragilidade da relação teleológica que Marx via entre o avanço do capital, a fortificação do proletariado e a revolução.

Tafuri vivia demasiado perto dos grandes dilemas da arte, ao mesmo tempo em que ladeava seu interesse com os caminhos políticos da Itália e da Europa. Portanto, se nutria muito de uma inteligência que pesquisava os embates entre arte e política.

\footnotetext{
${ }^{91}$ COHEN, Jean-Louis. "La coupure entre architectes et intellectuals", Op. cit. p. 188.
} 
Segundo a filósofa Giovanna Borradori, no debate estético do pós guerra italiano existiam duas correntes principais: uma organizada em torno do marxismo, segundo a qual "o intelectual deve ter uma relação 'orgânica' com a sociedade na qual vive e opera." A outra era a "existencialista e fenomenológica", que trabalhava mais com a ideia de "intersubjetividade histórica" "tanto dentro de processos cognitivos quanto sociais." ${ }^{\prime 2}$

Tafuri lia diversos autores, mas, de um modo geral, sua tendência no período parecia favorecer, ao menos em um sentido vago. a corrente mais interessada em uma revisão estética amparada em categorias marxista, cuja figura de grande destaque era Galvano della Volpe, filósofo e professor da Universidade de Messina. Francesco Dal Co depôs que na "formação [de Tafuri, foi importante] um historiador com forte interesse pelos termos de uma linguística, com atenção particular a um filósofo marxista muito conhecido na Itália chamado Galvano della Volpe". ${ }^{33}$ A fala do colega veneziano de Tafuri apenas corrobora factualmente o que já se pode intuir pelos artigos da juventude do autor, mas sobretudo em "Teorias e história”, quando admite que "no âmbito do pensamento marxista italiano, Galvano della Volpe teve um discreto sucesso, reconhecendo às estruturas figurativas uma lógica específica." ${ }^{14}$

Malgrado o pragmatismo, della Volpe resguarda a autonomia da arte diante dos processos produtivos. A contribuição disto era clara: "Desvinculava o pensamento marxista sobre arte das margens do sociologismo 'vulgar', reinserindo-o no debate avançado dos estudos internacionais sobre o problema da semântica." ${ }^{\text {95 }}$

Para Tafuri, Della Volpe conseguia de certa forma conciliar a história - e a história da arte - ao engajamento político, dando subsídio para uma prática artística sem recair em romantismos. Della Volpe lutava pelo caráter finito da arte, ligado ao presente, mas reconhecia a força das sensações, dos significados que a arte teria ao longo do tempo. O comentador brasileiro Wilcon Pereira defende que:

\footnotetext{
${ }^{92}$ BORRADORI, Giovanna. "Weak thought and Postmodernism: The Italian Departure from Deconstruction”. In: Social Text, n.19, 1987-88, p. 41.

${ }^{93}$ Depoimento de Francesco Dal Co. Cf. COHEN, Jean-Louis. "La coupure entre architectes et intelectuels". Op. cit. p 187.

${ }^{94}$ TAFURI, Manfredo. Teorie e storia dell'architettura. Op. cit. p. 236.

${ }^{95}$ Idem, p. 236.
} 
Della Volpe faz evoluir seu projeto de dotar o marxismo de uma 'estética dos meios expressivos'. A ideia central reside na verificação de que a obra é conbecimento, porém de gênero muito específico e peculiar, pois coloca em ação efetiva inúmeros procedimentos técnicos, formais $e$ materiais. (...) Um poema, um filme, um balé ou um desenho são modalidades do conhecimento, mas de um conhecimento realizado através de signos próprios, e portanto irredutivel e insubstituivel. ${ }^{96}$

Esse traço da obra de Della Volpe justifica muito do conteúdo presente as análises das vanguardas feitas em "Teorias e história da arquitetura" até sua obsessão filológica em pesquisas como "Via Giulia" e "Busca do Renascimento". Entretanto, nos anos sessenta, é possível inferir que os realismos 'expressivos' de Della Volpe apareciam para o jovem Tafuri como um endosso à sua prática de arquiteto, amparando-se na força que o presente teria ao se nutrir do passado como motor, conforme escreveu: "deveria ser esclarecido o sentido da contemporaneidade materialista, ou seja prática da bistória como um produzir história futura mediante a realização de instâncias de um presente que assoma e desenvolve em si a história passada. ${ }^{" 7}$ Este amálgama de tempos que se jogam no presente amparam-se no passado não por apriorismos, mas por 'critérios-modelos ou tipos', o que seriam abstrações históricas que seriam cotejadas com o presente para que se pudesse de fato alcançar, nele possibilidades de uma 'história futura ${ }^{98}$.

No debate no qual apresenta seu projeto de Latina, Tafuri termina seu discurso dizendo que poder afirmar que "uma das tarefas principais do arquiteto hoje é a busca de estruturas expressivas capazes de recolocar, em um nivel diferente daquele experimentado pela poética construtivista, o problema da relação entre ideologia e

\footnotetext{
${ }^{96}$ PEREIRA, Wilcon J. “Introdução”. In: Della Volpe, São Paulo: Ática, 1979, p. 35.

${ }^{97}$ DELLA VOLPE, Galvano. "Sulla dialettica". In: Logica come scienza storica. Roma: Editori Riuniti, 1969, p. 281. Grifo de Della Volpe.

${ }^{98}$ Idem, p.281.
} 
configuração, advertindo além disso que é já inadmissível seja a simples identificação de um termo com o outro, seja a sua absoluta separação." 99

A busca de 'estruturas' insere-se naqueles 'critérios modelo' de della Volpe, tanto quanto sua pesquisa histórica via-se embebida desta vontade de legitimação. A pesquisa tipológica de Le Corbusier feita no edifício de Latina era um modo de dar um 'nível diferente' do racionalismo do arquiteto suíço. É possível que Tafuri tivesse a intenção de ligar a escala da megaestrutura feita em projetos como Turim e Fano - e Veneza - com a escala das intervenções menores, utilizando-se assim do mais legível vocabulário de Corbusier: um edifício habitacional que fazia de modo expressivo a articulação de distintas escalas. O fato de, dentro das pesquisas monumentais do suíço a Unité se apresentar como um 'passo para trás', importava menos na conjuntura da cidade de Latina do que o jogo plástico. É sofisticada a relação geral entre prática e história no Tafuri dos anos sessenta: a filologia e as pesquisas sobre cidades e histórias aparecem nas pesquisas projeturais de modo não literal. As referências de projeto utilizadas na sua prática eram opositoras das suas obras mais comentadas, e em alguns casos até mesmo tidas como 'menos interessantes' no quadro geral de sua teoria. Referências utilizadas na sala de aula como exemplares não apareciam em sua prancheta.

$\mathrm{Na}$ prancheta, Tafuri tinha uma postura conservadora: gostaria de trabalhar sobre as postulações do movimento moderno para a partir dele abrir novos horizontes de atuação. Era muito cético acerca de correntes ue buscavam escapar do debate das vanguardas. Acreditava que esse era um caminho válido que demandava um trabalho intenso e cuja possibilidade de ruptura era menos urgente do que uma 'reinserção' da arquitetura na história.

$\mathrm{Na}$ introdução de seu curso de 1964 - sobre a história da arquitetura moderna à luz dos problemas atuais - o discurso orbita em torno do reconhecimento do poder histórico da atuação em projeto. “...É o caráter obrigatoriamente construtivo da arquitetura que a conduz a oferecer horizontes de superação da crise...” ${ }^{100}$

Essa visão advém sobretudo do cenário italiano, para quem o legado das vanguardas teve sempre de bater-se com a vasta tradição arquitetônica italiana, ainda

\footnotetext{
${ }^{99}$ TAFURI, Manfredo. "Progetti di architetti romani", Op. cit. p. 11.

${ }^{100}$ TAFURI, Manfredo. La storia dell'architettura moderna alla luce dei problemi attuali, Op. cit. p. 2.
} 
tendo de lidar com um espólio da difícil relação entre racionalismo e correntes de direita. Escrevendo sobre seu professor - e chefe por alguns anos - Ludovico Quaroni, Tafuri tece uma introdução eloquente, na qual procura colocar o protagonista como uma figura central nos debates do seu período. Ali, diagnostica o problema da arquitetura na história.

A recuperação da história andava cumprindo dentro das complexas problemáticas da realidade italiana, com a intenção, não aquela de técnico indiferente que aceita toda situação ou programa, que se coloca como solucionador $e$ racionalizador dos problemas postos pela sociedade, (...) mas dando à palavra 'realidade' um significado histórico, de situação instável na qual a escolha é inevitável ainda que, frequentemente, dramática. ${ }^{101}$

Essa significação do presente tinha de ser sofisticadamente apoiada no passado e, por passado, também considera-se o legado das vanguardas. Esse nexo de questões inspirava o jovem arquiteto que, buscando sempre lastrear a sua angústia com o projeto e com sua geração de colegas, voltava-se para a teoria. Teoria no senso mais amplo que o campo da arquitetura: a sua apreensão do termo 'história da arquitetura' aparece primeiro dentro de um projeto de atuação que considera ainda o projeto e suas possibilidades. A busca por intelectuais, filósofos, historiadores de arte que marcam os anos de formação de Tafuri serão retomados nos anos posteriores, mas, ali, na primeira metade dos anos sessenta, serviam-lhe mais para dar diretrizes de como intervir no presente, na contingência, e isso passava pela atividade de projeto.

$\mathrm{Na}$ sua atuação como historiador, Tafuri então mantinha um estudo autônomo das referências. $\mathrm{O}$ entremeio histórico aparecia em seus textos sobre a cidade, numa chave literal de que, afinal, o contemporâneo e a parte "histórica" das cidades apareciam justapostos no tecido existente e nas discussões de projeto. Nesse período, entretanto, os entremeios de tempos improváveis ainda inexiste nos moldes que

\footnotetext{
${ }^{101}$ TAFURI, Manfredo. Ludovico Quaroni e lo sviluppo dell'architettura moderna in Italia. Milão: Comunità, 1964, pp. 9 e ss.
} 
marcaram a história de Tafuri. Seus artigos sobre o humanismo, durante esses primeiros anos, foram sobretudo de caráter acadêmico, para os Quaderni dell'Istituto di Storia dell'Architettura. Ali, pesquisam-se os temas que interessariam o historiador, como o barroco italiano, a cidade de Roma. Pode-se ter a impressão de que o historiador tivesse, naquele período, um interesse pessoal pelo estudo de um passado mais distante que o das vanguardas. Entretanto, as suas escolhas de estudo entravam em sua intenção de trazer ao presente a força do passado: mesmo sem o entremeio histórico, Tafuri já tece uma busca de dilemas históricos que fomentem sua atividade.

No livro publicado em 1966, “A arquitetura do maneirismo no 500 europeu”, aparece uma explicação mais clara acerca de seu entendimento da relação entre passado e presente. A obra foi feita, segundo o próprio Tafuri, com um senso de urgência para publicar obras, como meio de aumentar suas chances num concurso de professores que abriria. No entanto, mesmo renegada, ela contêm aspectos interessantes sobre como o autor via a relação entre presente e passado. $\mathrm{O}$ maneirismo, estudado pelo autor, justifica-se como uma "tentativa de colher valores específicos, além das poéticas e estilísticas particulares."

Tido como um momento de crise, o período considerado mais angustiante do humanismo é escolhido como recorte por Tafuri por um interesse estratégico, algo que o autor chama de "atualidade histórica", justificada pela vontade de se fazer "um colóquio com a história, afinal, baseado sobre estruturas linguisticamente abertas e semanticamente polivalentes, no limite em que tais termos possam referir-se à cultura quinhentista." 102

A ligação anuncia aquelas que faria Tafuri nos seus anos posteriores, mas ainda guarda um pragmatismo incomum posteriormente. Se em "Teorias e história" os dilemas de Brunelleschi e de Alberti serão retomados em pleno estudo da arquitetura contemporânea, foram menos com a intenção de colocá-los como situação análoga do que como ecos de um mesmo dilema. $\mathrm{O}$ maneirismo e a arquitetura moderna não se ligam, na metade dos anos sessenta, do mesmo modo que o humanismo e o contemporâneo. Existiu uma modificação no meio como a história encontra a arquitetura, e um dos passos dessa transformação de Tafuri passa pelo corte definitivo do projeto como uma alternativa ou, no limite, como via de escape.

${ }^{102}$ TAFURI, Manfredo. L'architettura del Manierismo nel '500 europeo. Roma: Officina, 1966, pp. 6 e ss. 
A “crise de Tafuri” tem um capítulo definitivo quando Della Volpe decide responder a um artigo seu escrito em 1961, junto com Benevolo, para a revista "Argomenti di architettura". Os dois arquitetos defendiam que "tendendo a definir a condição humana do arquiteto na trama das relações com a dimensão social na qual é direcionado o seu fazer, deverá, partindo portanto do presente, transformar ao passado para depois mover-se do passado de novo partindo do presente, sempre do presente, para o futuro."

A passagem tem concomitâncias com della Volpe. Entretanto, o próprio autor resolveu escrever uma resposta, intitulada “A questão central da arquitetura hodierna”, na qual contesta esta passagem à luz da questão de William Morris, que partia da poética artesanal, fundada no passado, que acabou contaminando o seu socialismo com grande dose de romantismo e nostalgia medieval. "Parece lícito", escreveu della Volpe, "trazer um aviso verdadeiramente atual aos teóricos de arte (em geral) e aos arquitetos: o aviso de não perder também nós o contato com a realidade do nosso tempo, econômica, social, cultural, e portanto evitar refugiar-se em uma realidade refletida em formas de uma cultura passada, usada, datada..." ${ }^{104} \mathrm{O}$ parágrafo termina como uma advertência: "Senão, permaneceremos ainda prisioneiros em estética daquele esteticismo, ou superestima da imagem (e portanto do ornamento da arquitetura) e escaparemos do conceito (e portanto do útil e humanamente funcional), que foi já felizmente combatido pelo moderno movimento revolucionário na arquitetura." 105

Nesta passagem, tem-se que as elucubrações de Tafuri acerca das vias projetadas em Roma, tema de seu primeiro artigo de 1959, ou suas pesquisas da Villa Savoye, bem como sobre a barroca ampliação de San Gregoria da Sassola são demasiado distantes do pragmatismo de della Volpe. Mesmo o Corbusier da Unité, cujo ímpeto moderno era já datado no arquiteto suíço, entravam de modo torto no realismo desenhado por Tafuri. Della Volpe tinha no presente o grande foco de atuação, no qual os 'critérios modelos' e as buscas históricas pelo passado eram

\footnotetext{
${ }^{103}$ TAFURI, Manfredo. “L'informale e il 'design' contemporaneo”. In: Argomenti di architettura, n. 4, 1961, p. 94.

${ }^{104}$ DELLA VOLPE, Galvano. "La questione cruciale dell'Architettura odierna". In: Critica del gusto, Milão: Feltrinelli, 1966, p. 162.

${ }^{105}$ Idem, p. 162.
} 
empecilhos para que não se fizesse filosofia "negligenciando o problema das raízes do presente, arriscando perder-se em um presente abstrato, irreal e afinal impotente."106

A resposta de Tafuri veio em "Teorias e história da arquitetura", primeiramente numa nota na qual o autor atesta que a passagem crítica de Della Volpe é "certamente o mais carente do volume todo"107. Iniciando por um balanço crítico do filósofo, Tafuri admite que o mérito de Della Volpe reside na ligação da crítica semântica com a da arte e arquitetura. A abertura de significados e o caráter orgânico da arte eram, no entanto, relativizada pelo jovem autor, quando se encontrava diante de "fenomenos artísticos não orgânicos, desarticulados, 'abertos', como o Dada, o informe, a Pop Art ou a arquitetura na escala urbana." ${ }^{108}$

A associação entre as mais iconoclastas correntes artísticas do século XX e a escala urbana da arquitetura tem, assumindo a carreira do autor, um favorecimento ao segundo termo. A escala urbana é um constante transformar-se de significados, reabertos e relidos sempre que se tem novas construções, regimes etc.. Como dar conta deste movimento? Conforme o autor, existe um ponto cego neste movimento do presente para o passado, especialmente no fato de que o passado está em constante revisão de suas significações e de seus sistemas de significações. "A codificação dos sistemas de decifração podem mudar e reenvolver a inteira história da arquitetura para o aparecer de uma obra que, sozinha, esclareça um processo primeiramente pouco evidente (....) ou para descoberta da valorização crítica de obras ignotas ou não ainda lidas adequadamente."

Esta polêmica com Della Volpe tem um posicionamento central em "Teorias e história da arquitetura”. A argumentação do autor romano, ao dar como resposta aos dilemas das constantes mudanças de significados das cidades o estudo de obras menores ou esquecidas clama por uma “individuação de códigos de referência.” Neste procedimento, alerta Tafuri, é preciso ter o cuidado de não se deixar seduzir pelo presente e se incutir em deformações. O sentido deste raciocínio culmina na conhecida passagem:

\footnotetext{
${ }^{106}$ DELLA VOLPE. Galvano "Sulla dialettica" Op. cit. p. 282.

${ }^{107}$ TAFURI, Manfredo. Teorie e storie dell'architettura. Op. cit. p. 236.

${ }^{108}$ Idem, p. 237.
} 
Neste sentido se pode bem dizer que todo tipo de crítica voltada a por exatamente em luz as relações que ligam uma obra ao código a ela implícita, é operativa. Ela, de fato, modifica os nexos que ele mesmo indaga. ${ }^{109}$

Tafuri está conversando com seus interlocutores mais específicos - a geração anterior de historiadores de arquitetura, sobretudo Zevi, que era professor no "Curso de crítica operativa de arquitetura". Entretanto, acredita-se que o pano de fundo para estas considerações críticas ao ladeamento entre arquitetos e historiadores é seu debate com Della Volpe. Esta conexão entre a crítica à crítica operativa e sua atividade como arquiteto sugere um ponto nodal na reação de Tafuri à uma crítica como a de Della Volpe: diante da impossibilidade de se subscrever à sucessão do passado pelo presente, na medida em que ela implica um juízo arbitrário daquele por este, o autor romano prefere ladear-se a uma visão mais compacta da relação entre tempos. A individuação dos códigos de referência no passado servem para trazer uma significação unicompreensiva entre o passado e presente. Neste sentido, Tafuri percebe a força da plástica de Corbusier em Chandigarh ao tecer um entremeio de tempos e signos que alcança uma temporalidade congelada ${ }^{110}$. Ali, mais do que a recorrência de "critériosmodelos”, fica a relação entre tempos mais ligada a uma noção atímica. Esta noção liberta o corpus teórico de Tafuri da conjuntura, dando ao seu engajamento político no presente termos menos imediatos e permitindo que ele consiga construir, ao longo dos anos seguintes, uma história da arquitetura na qual a relação entre a época moderna e contemporânea é feita a partir das particularidades do passado, para que pelo seu estudo se possa alcançar de modo novo o presente. Sem esta modificação, seria difícil pensar na inserção de Tafuri em Veneza no círculo da "Contropiano", mas sobretudo, considerar que o seu trabalho como historiador pudesse subsistir sem o amparo em uma rigorosa tarefa filológica.

O preço desta guinada teórica é bem conhecido: para que passado e presente possam ser compactados, é necessária uma visão não sucessiva de tempos. Isto requeria do jovem Tafuri que suas investigações de prancheta entrassem então em

\footnotetext{
${ }^{109}$ Idem, p. 238. Grifo de Tafuri.

${ }^{110}$ TAFURI, Manfredo. L'architettura moderna alla luce dei problemi attuali, Op. cit. p.58.
} 
oposição direta com seus escritos: construir significa colocar no presente algo estranho ao passado, rompendo a cadeia que os une, cuja captação só pode ser feita pela prosa escrita. Quando Tafuri escreve, ao princípio de “Teorias e história”, que "criticar significa, na realidade, apreender a fragrância histórica dos fenômenos, submetê-los ao crivo de uma rigorosa avaliação, revelar as suas mistificações, valores, contradições e dialéticas íntimas, fazer explodir a sua carga de significados" ${ }^{111}$, aponta para o declínio das "ferramentas" de projeto.

Nesta direção, não faz sentido falar de uma "escolha" pela história. No depoimento de Tafuri acerca de sua decisão profissional, a parte mais consistente é o não saber qual história seria feita, haja visto que era um momento no qual um modo de se fazê-la era suplantado por outra. Além do declínio do projeto, era necessário romper com uma geração de arquitetos italianos interessados em fazer projeto sendo informados pela história. "Teorias e história" tem um viés de discussão de questões italianas, ao procurar investigar o "eclipse da história" como feito durante as vanguardas, tanto quanto mostrar o elo nocivo criado entre os manuais de arquitetura escritos por Zevi, nos quais se procura advogar pela arquitetura orgânica. Entretanto, Bruno Zevi é apenas o intelectual mais significativo desta tendência, na qual poderia se inserir a maior parte da inteligência italiana arquitetônica. A decisão de Tafuri por uma história filológica o ladeia aos historiadores de arte antiga e moderna, como Sergio Bettini, e de certo modo causou uma maior aproximação de Tafuri com a outra tendência "antifascista" que Borradori definira, de filiação mais fenomenológica, como Enzo Paci, cuja leitura sobre a arte na história tinha maior afinidade com a possibilidade de um tempo congelado:

Posicionado entre o passado e o futuro, entre isso que foi e o que deve ser, o artista, ouvindo a voz que o chama, é como se tudo se transmutasse em uma pergunta e uma pesquisa: é como se todo o processo universal o condicionasse previamente a descobrir e escolher uma nova via. O artista tem a impressão de encontrar-se diante de infinitas

\footnotetext{
${ }^{111}$ TAFURI, Manfredo. Teorie e storia dell'architettura, Op. cit. p. 21.
} 
possibilidades, de infinitas vias, em tempos e espaços infinitos. $^{112}$

"Teorias e história” não pode ser considerada a obra com que Tafuri se despede da atividade de projeto, tendo em vista que quatro anos antes, desde 1964, seu nome desaparece dos catálogos das revistas, e começa-se verdadeiramente uma produção mais sólida do autor como teórico, publicando livros como "Ludovico Quaroni” e “Arquitetura moderna no Japão”. A obra de 1968 é, no entanto, o testemunho final de uma mudança de orientação política de Tafuri dentro dos debates da península. Sua decisão por uma determinada história que se coloca à distância da conjuntura, como opositora das correntes contemporâneas, pautada pelo aprofundamento filológico tem como substrato a modificação de sua noção de tempo, ou de sua compreensão de como a arquitetura e as cidades participam do devir. A arquitetura tem uma participação no presente quando ela coincide com os tempos do passado, com os dilemas do passado. Essa é a verdadeira 'escolha' feita por Tafuri durante a década de sessenta: a escolha por um tempo de longa duração.

Não se tratava da escolha mais fácil. Além de ter de deixar uma parte de sua atuação profissional, Tafuri teve de lidar com uma revisão completa de como ele desenvolvia a pesquisa histórica. A relação entre arte e realidade teve de ser revista. Não à toa, ao chegar em Veneza, sua vinculação mais forte com o operaismo vai levá-lo a uma pesquisa de crítica à ideologia que procure resolver sobretudo uma problemática dos meios pelos quais o arquiteto interveio na formação das cidades durante o século $\mathrm{XX}$.

No legado desta curta fase como arquiteto, restaria uma última parte em aberto: Tafuri, segundo seu colega Piccinato, tinha uma "notável capacidade de desenho" ${ }^{113}$. Soma-se a isto seu interesse de juventude pela escultura, tanto que Piccinato depôs acerca da participação do colega em concursos para mausoléus que tinham lhe rendido boas colocações. Em complemento à prosa escrita de Tafuri, o desenho viria a suplantar a sua prática histórica, no lugar do projeto. A busca por desenhos e croquis feitos para os seus livros de juventude, se existem, ainda não estão

\footnotetext{
${ }^{112}$ PACI, Enzo. Tempo e relazione. Milão: Il Saggiatore, 1965, p. 251.

${ }^{113}$ Depoimento de Giorgio Piccinato.
} 
disponíveis para verificação, mas uma publicação do "Centro Internazionale di Studi di Architettura Andrea Palladio”, o CISA, mostra alguns desenhos do autor feitos durante suas pesquisas mais recentes. É fato que desde o princípio de sua carreira existem desenhos técnicos de investigação formal sobre informação filológica, o que se manteve ao longo dos anos na obra de Tafuri. Na mostra, aparecem desenhos de estudos para os diagramas acerca dos cortes e fachadas do projeto para a igreja de San Giovanni dei Fiorentini, em Roma, desenhado por Antonio da Sangallo o jovem. Seu projeto perdeu o concurso feito pelo papa Leão X, sobrando apenas as informações de desenho. No texto sobre o projeto, publicado em "Busca do Renascimento", Tafuri mostra como as decisões iniciais de Sangallo poderiam ir por dois caminhos completamente distintos, sendo uma em planta basilical e outra central. "Tal tipo de abordagem é característico de Sangallo e revela uma sintomática indiferença pelas escolhas de princípio." 114

Os desenhos técnicos passados a limpo por um desenhista aparecem no livro como esquemas das investigações de Tafuri, mas os croquis que os antecedem mostram medidas de cotas feitas pelo autor romano. $\mathrm{Na}$ argumentação presente no livro, Tafuri quer contrapor o projeto basilical de Sangallo ao Pantheon, logo vizinho ao terreno, colocando motivos com um templo imaginário descrito na "Hypnerotomachia Poliphili", onírica obra atribuída ao veneziano Francesco Colonna, como modo de mostrar seu modo de lidar com o passado antigo através deste jogo de contraposições.

“Tafuri se gabava (...) da sua capacidade de assumir o papel dos arquitetos que estudava"115, diz Howard Burns, colega de Tafuri e um dos curadores da mostra de seus desenhos, sugerindo que até mesmo a caligrafia dos autores que pesquisava era objeto de sua "representação". Os desenhos dão assim suporte ao texto sóbrio do autor, ao mesmo tempo em que o leva a uma "reconstituição" do processo criativo de Sangallo. Os procedimentos de desenho aprendidos na Valle Giulia eram indispensáveis para a perseguição filológica dos seus temas, tornando-se não só uma peça fundamental de sua contribuição histórica, mas também um enunciado

\footnotetext{
${ }^{114}$ TAFURI, Manfredo. Ricerca del Rinascimento. Op. cit. p. 164.

${ }^{115}$ BURNS, Howard. "Questo': disegni e studi di Manfredo Tafuri per la ricostruzione di edifici e contesti urbani rinascimentali”, In: 'Questo': disegni e studi di Manfredo Tafuri per la ricostruzione di edifici e contesti urbani rinascimentali. Vicenza: CISA, 1995, p. 15.
} 
provocativo para a compreensão de sua prosa escrita. $\mathrm{O}$ uso da imagem nos textos de Tafuri nunca é tautológico: excluindo-se os trabalhos mais didáticos, como "A arquitetura moderna no Japão", as fotografias e desenhos não tem uma explicação literal ao longo do texto, mas uma presença ruidosa no seu conteúdo. Lipstadt e Mendelsohn, ao estudar a persistência de Le Corbusier na obra de Tafuri, aponta para o uso de fotografias insólitas, cujo significado foge à prosa. Amparando-se em uma foto das rampas da Assembléia de Chandigarh, tirada do Secretariado, os dois comentadores chegam a novas conclusões.

“Em Chandigarh existe mais do que um 'silêncio irônico', existe um encontro de oposições - de linguagem e imagem (...). Na ausência de maiores esclarecimentos no texto de Tafuri sobre Chandigarh, pode-se ver a fotografia da Assembléia incluída nas ilustracões do primeiro capítulo. (...) O desfavorável ângulo de cima para baixo mostra a essencia literal do projeto e portanto enfatiza não só a inconcisão das conexões, visual e real, mas também a relação opositora entre elementos de circulação e acesso."

A seleção de imagens permite que se abram outras leituras à prosa do autor, colocando em um movimento crítico suas elaborações, existindo como um resquício de sua atividade projetual. Inverte-se a relação: agora, as imagens, os procedimentos e ferramentas de desenho e exposição de conceitos são auxiliares à prática filológica e crítica de ideologia. Neste sentido, não bastaria mais à imagem complementar o raciocínio de modo literal, mas contrapor-se a ele. O procedimento de desenho das obras do Renascimento são uma radicalização deste processo. Neste momento, Tafuri se aproxima de Le Corbusier, que por sua vez tinha uma obsessão em desenhar por cima de fotografias paisagens que se ofereciam diretamente à sua visão, como quem quisesse captar o olhar longínquo, ${ }^{117}$ o passado, necessário para que se pudesse congelar o tempo, fazer com que o fio vermelho que atravessa a história tivesse a mínima espessura.

Um aspecto final de ressalto, é que na mostra de Burns existem desenhos que não são diagramáticos ou técnicos. Existem perspectivas feitas por Tafuri de espaços que não foram construídos, como a igreja proposta por Sangallo. Ali, as cotas e

\footnotetext{
${ }^{116}$ LIPSTADT, Hélène e MENDELSOHN, Harvey, "Philosophy, History and Autobiography" Op. cit. p. 73 .

${ }^{117}$ COLOMINA, Beatriz. "Le Corbusier and Photography”,In: Assemblage, n. 4, 1987, pp. 6-23.
} 
medidas continuam, junto de ampliações de 'detalhes construtivos' e encontro de naves e outras peças. Pode-se supor que tivesse momentos onde de fato utilizasse a prancheta para resolver detalhes de projetos de outras épocas. "[Minha persona] trabalha com história como profissão (não como um historiador de arquitetura, mas também historiador de arquitetura)”, disse Tafuri certa vez. Esta fuga de um intelectual 'especializado' era constante em sua carreira. Certamente, nunca pode escapar de sua formação como arquiteto, que sempre esteve presente, ecoando em suas escolhas e no tempo de suas aproximações. 


\section{Cena, protagonista}

A partir de "Teorias e história da arquitetura", surgem com muito mais força temas sobre performance na obra de Tafuri. As suas argumentações frequentemente são pautadas por imagens em cima de termos teatrais: público, plateia, espetáculo, palcos, cenários. Em seus estudos as particularidades da atuação tocam a arquitetura não só na construção específica de teatros, mas sobretudo naquela da expressão cenográfica, do personagem, dos antagonismos, da ordem dramática que se constrói no palco.

Não chega a ser algo incomum este interesse, visto que Tafuri transitava por diversas artes, como suas análises dos quadros de Picasso em "Por uma crítica da ideologia arquitetônica", a onipresença da literatura em textos como "L'architecture dans le boudoir" e até mesmo a obra de músicos como Mahler foi alvo de aula completa em seu curso sobre Viena no século $\mathrm{XIX}^{118}$. Indagar-se sobre as leituras de performance feitas por Tafuri, portanto, poderia parecer mais um exercício de estudo metodológico, distante dos temas que tratam de sua compreensão temporal.

Entretanto, o teatro é mais do que uma atividade artística na prosa do autor romano: o corpus da obra de Tafuri é calcado não só na compreensão dos processos de desenvolvimento urbano, mas sobretudo na suas aspirações e símbolos, para a qual a imagem teatral, a partir de 1969, aparece como matricial. Tafuri deixou dois textos específicos sobre arquitetura de teatros: um sobre as performances nas vanguardas, "A cena como cidade virtual", e outro sobre os palcos na Itália moderna, "O lugar teatral desde o humanismo até hoje". Nestes dois textos a dualidade entre cena e urbe é o nó que sustenta a argumentação da prosa: às vezes, o teatro aparece como defasado acerca

${ }^{118}$ TAFURI, Manfredo. "Lezione 7: Gustav Mahler". In: La "Grande Vienna": dalla formazione del mito asburgico alla crisi dell'austromarxismo. Corso di storia dell'architettura. 2A: Trascrizione delle lezione tenute dal prof. Manfredo Tafuri nel corso dell'anno accademico 1977/78. A cura degli studenti iscritti al corso, IUAV, pp. 7:17-7:19. 
das performances que a cidade já impõe aos seus moradores, como no caso do "Teatro total” de Gropius, onde a megaestrutura cenográfica é considerada supérflua, pois a “cidade real já é teatro total" ${ }^{119}$. Em outros momentos a relação é inversa, nos quais o teatro aparece como ponto de partida para a afirmação de uma ambição sobre a cidade, como o Teatro Ideal de Ferrarese, considerado pelo autor um "monumento da vontade burguesa de por a cidade sob o próprio domínio". ${ }^{120}$ Também ressoam ecos deste tema em diversos outros ensaios do autor; pode-se lembrar sua análise do teatro de Aldo Rossi em Veneza, ou as comparações das correntes americanas dos anos setenta com 'malabaristas' e até mesmo a ideia de performance implícita na famosa alusão do crítico a um equilibrista feita no princípio de "Teorias e história da arquitetura": "O crítico é aquele que é fadado, por escolha pessoal, a manter seu equilíbrio sobre um fio, enquanto ventos que mudam continuamente de direção fazem de tudo para the provocar a queda." ${ }^{121}$ Também vale lembrar o interesse do autor romano nos estudos de imagens de espaços, privilegiando nas suas análises a presença das pessoas nestes lugares; como nas ánalises dos Carceri de Piranesi presentes em "A esfera e o labirinto" e "Projeto e utopia", onde se analisa a figura do torturado como "um ser super-humano, rodeado de uma massa indistinta" ${ }^{22}$ e, finalmente, o croquis de Le Corbusier para o Plan Obus, comentando os modismos decorativos aplicados nas células residenciais ${ }^{123}$.

Trata-se, portanto de algo mais do que uma atividade artística: o teatro na obra de Tafuri é expressão dos recalques de ambições irrealizadas, projetos inacabados e fragmentos deixados à margem dos processos práticos de construção da cidade. $\mathrm{O}$ teatro é capaz de sintetizar espaço e experiência das cidades como um microcosmo, tanto quanto a trama compacta as relações sociais, a cena sintetiza as idiossincrasias de seu ambiente circundante, dando um caráter espacial à catarse. $\mathrm{O}$ ator é, por sua vez, uma metáfora daquele que experiência a vida urbana e que nela intervêm, é aquele que vive de forma dramática em torno dos desejos e expectativas da arquitetura.

\footnotetext{
119 TAFURI, Manfredo. La sfera e il laberinto. Avanguardie e architettura da Piranesi agli anni '70'. Tradução para o espanhol La esfera y el labirinto. Vanguardias y arquitectura de Piranesi a los años setenta. Barcelona: Editorial Gustavo Gili, 1984, pp. 142 e 143.

120 TAFURI, Manfredo. "Il luogo teatrale dallumanesimo a oggi". In: SQUARZINA, Luigi; TAFURI, Manfredo, Teatri e scenografie. Milão: Touring Club, 1976, p. 35.

${ }^{121}$ TAFURI, Manfredo. Teorie e storia dell'architettura. Op. cit. p. 5.

${ }^{122}$ TAFURI, Manfredo. Projecto e utopia. Op. cit. p. 22.

${ }^{123}$ Idem, p. 67.
} 
Em "Para uma crítica da ideologia arquitetônica" Tafuri lançou as linhas-guia de um estudo de história da arte que fizesse a revisão do caráter de ruptura feito pelas vanguardas artísticas, especificamente nas suas postulações urbanísticas. É bem conhecido o argumento do autor segundo o qual as ambiguidades perceptivas advindas do rápido crescimento dos grandes centros urbanos exigiam uma instrumentação do uso prático da cidade industrial. Tal instrumentação é estética: só através dela se pode estabelecer vínculos reais entre forma e conteúdo na sociedade metropolitana. Tafuri faz uma longa introdução sobre os grandes centros e a presença da arte neste processo, analisando a imposição desta atividade como modelo de ação: o artista lança novos parâmetros de percepção e apreensão dos estímulos e sinais. Este lançamento tem um caráter dramático:

O público deve ser provocado: só assim pode ser inserido ativamente no universo da precisão dominado pelas leis de produção. A passividade do flâneur cantado por Baudelaire deve ser vencida: a atitude blasé deve ser traduzida em comparticipação ativa na cena urbana. ${ }^{124}$

Tem-se aí uma aproximação literal da experiência metropolitana com a performance: $\mathrm{O}$ habitante da cidade é tratado como público, a experiência citadina é posta no texto como espetáculo; o termo cena urbana coroa a imagem. Cena, neste contexto, aparece como uma construção de limiar; segundo o autor, a pretensão contemporânea de integrar arte e vida cotidiana requereria um instrumento de

${ }^{124}$ TAFURI, Manfredo. "Per una critica dell'ideologia architettonica", In: Contropiano, n. 01, 1969, p. 54. Primeiro e segundo grifo do autor, o último meu. Para mehor sustentar tal ponto de vista, pode-se apresentar a título de contraste a passagem na qual $\mathrm{Dal} \mathrm{Co}$, em seu artigo de tema símile, expõe o elo entre ideologia e utopia: "A tarefa que a arquitetura, consequentemente a este tipo de análise se assume, é de fornecer ela mesma o termo de união entre produção em geral e indivíduo, fazendo com isso possível a 'civilização': trata-se de certo modo de realizar uma relação 'mais humana' entre indivíduo e produção, dando à produção novos instrumentos e conteúdos e oferecendo ao indivíduo a possibilidade de alcançar um alto grau de consciência dos fins sociais do próprio trabalho." (DAL CO, "Note per la critica dell'ideologia dell'architettura moderna: da Weimar a Dessau", In: Contropiano, n. 01, 1968, p. 168). Enquanto Dal Co via ideologia como um acordo tácito entre metrópole e cidadãos. Tafuri posiciona a 'comparticipação' do indivíduo em termos menos imediatos: mais do que abraçar uma nova 'civilização', a ideologia das vanguardas só se realizaria mediante uma ação dramática, uma performance não de conciliação com a nova metrópole, mas de 'enfrentamento' contra o apagamento do indivíduo na máquina urbana - tarefa que sempre será trágica, na medida em que ineficiente, pois qualquer medida de contestação recai sempre em uma busca mecânica de libertação. 
mediação, uma margem de ensaio. A alusão ao teatro vem como imagem de uma ideologia ostentada pelas vanguardas artísticas acerca dos usos da metrópole industria $1^{125}$. A participação do público, menos de que de assunção do papel de protagonistas dentro de um drama, são antes o comportamento preestabelecido dentro da estrutura social: como mais uma oportunidade das massas de clamarem com fúria a sua presença, sem tocar na estrutura que promove a sua exploração.

A história da arte poderia dar uma efetiva contribuição à filosofia materialista, ainda que carregasse sempre a marca de estar no âmbito da superestrutura. Pelos idos de 1969, tal tema não era exatamente novo nas rodas de caráter revisionista, e nem mesmo no acervo técnico da revista: um ano antes o jovem Francesco Dal Co publicara um ensaio intitulado "Notas para a crítica da ideologia da arquitetura moderna: de Weimar à Dessau”, com uma pretensão símile de demonstrar o caráter ideológico da arte abstracionista e sua ligação com os grandes centros metropolitanos ${ }^{126}$. O artigo de Tafuri se destacou pelo modo como este resolveu melhor a questão da penetração das premissas vanguardistas nos mais prosaicos usos da cidade: a qualidade da articulação entre ideologia e utopia é o grande mérito do autor romano, que lhe levou às diversas considerações que fizeram este texto ser considerado seminal e ainda o mais conhecido do autor no que concerne diretamente a arquitetura contemporânea. Estas articulações são fulcrais para a compreensão da influência dos círculos marxistas venezianos na obra de Tafuri, mas sua pertinência deve-se menos ao seu teor engajado do que à sua leitura da cidade como um grande cenário: assim sendo, mais do que o local excelente da extração de mais-valia, ela é antes de tudo o local onde esta é performada. O filósofo Massimo Cacciari escrevera que a metrópole era a "forma geral que assume o processo de racionalização dos processos sociais." 127 Tafuri leva tal raciocínio ao limite mostrando que tal racionalização não poderia se dar dentro de uma estrutura realmente otimizada: o grande centro, para funcionar de fato como um locus dominado pelas leis de produção, deve menos ser uma máquina otimizada do que convidar os seus usuários a construí-la

\footnotetext{
${ }^{125}$ Sobre o artigo, Tafuri escreveria: "O que nos interessa neste ponto, é definir quais são as funções que o desenvolvimento capitalista retirou à arquitetura: isto é, que retirou, em geral, às prefigurações ideológicas", TAFURI, Manfredo. Projecto e utopia, Op. cit. p. 10.

${ }^{126}$ DAL CO, Francesco. "Note per la critica dell'ideologia dell'architettura moderna", Op. cit. pp. 153170.

${ }^{127}$ CACCIARI, Massimo. Metropolis: Saggi sullla grande città di Sombart, Endell, Scheffler e Simmel. Roma: Officina Edizioni, 1973, p. 9.
} 
como tal. A dialética entre vanguardas construtivas e destrutivas tal como Tafuri aponta, pela qual uma procura organizar a fragmentação caótica de estímulos que a outra busca explicitar, permite tornar coerente movimentos tão distintos e acontecidos em partes diferentes da Europa, faz com que Tafuri conclua que tais condicionamentos recaiam em uma performance maquinal diante da experiência nas cidades. A improbabilidade e polifuncionalidade da metrópole, malgrado atuem como turbulência em tal tema, são paulatinamente absorvidas em um jogo de costumes, gestos e procedimentos que visam dar a elas valor de pano de fundo. A metrópole, na interpretação de Tafuri, não uma máquina: é uma cenografia maquinal. Para o autor ela é antes de tudo uma peça do sistema cuja função é dissimular uma eficiência completa, ao mesmo tempo em que opera com signos e utopias de uma nova reestruturação social.

O ator, ou o protagonista, é o habitante genérico da cidade - as massas anônimas que vagariam pela cidade seguindo os ritmos da produção. Em "Por uma crítica...” Tafuri está interessado em dialogar com seus colegas acerca dos rumos da experiência citadina - assim, sua interpretação é excessivamente ligada a uma idéia de automatismos esquemáticos que ainda excluíam uma possibilidade de contra-discurso ou, simplesmente, de um sujeito histórico que pudesse fazer frente à reorganização das cidades. Não à toa este ensaio faz uma análoga homogenização das correntes e movimentos - todos são citados en passant e, mesmo reconhecendo-se as diferenças de suas pretensões, são afinal colocados todos dentro de uma mesma moldura ideológica.

"Teorias e história da arquitetura", ainda que seja mais contido nas suas posições acerca das vanguardas, tem posições mais consistentes como ensaio das relações de performance nas cidades. Se em "Por uma crítica...” Tafuri enfrentou os compromissos firmados entre vanguardas e cidade moderna, no seu livro anterior o autor preferiu uma análise mais usual entre os historiadores europeus, que busca os rastros da tradição histórica dentro dessas correntes radicais. Em "Teorias e história”, Tafuri atenta ao fato de que o tecido existente nas cidades pré-capitalistas não serve às exigências tão específicas da performance maquinal, em parte pela sedimentação muito legível de diversos tempos históricos que remeteriam a diferentes modos de se fruir a cidade - as pedras fundamentais, os monumentos, muralhas, os registros de 
outros períodos. Segundo Tafuri, os ataques às preceptivas artísticas engajados pelas vanguardas recaiam sobre a noção histórica dos edifícios.

Tafuri faz um itinerário começando nas dicotomias entre as leituras do gótico feitas por Brunelleschi e Alberti, para mostrar como a manipulação da história é procedimento comum desde a aurora da modernidade. A retomada de valores clássicos seria contraposto a uma cidade medieval, cuja organização é visceralmente diferente daquela da antiguidade, o que colocava qualquer retomada da tradição como ato pleno de desafios e provocação.

“A história”, escreveu o autor, "não é portanto representável, nessa concepção, segundo uma linha contínua. É antes uma linha quebrada, determinada por um critério de escolha arbitrário que caso a caso fundamenta os seus valores e finalidades". ${ }^{128}$ A negação da história é um movimento que remonta à época moderna. Entretanto, a sua negação mesma é histórica - cria um senso de época que permite uma interlocução com o tecido consolidado.

Modernidade e contemporâneo tem problematizações análogas. A grande diferença é que nas Luzes a arquitetura não se ocupará em conceber suas edificações contrastando ou dialogando com períodos anteriores - surgem os primeiros ímpetos de uma remodelação total da cidade para melhor comportá-la em modos de vida racionalizados. "Renunciando a um papel simbólico, pelo menos no sentido tradicional, a arquitetura - para evitar sua própria destruição - descobre a sua vocação científica." ${ }^{129}$ Passa-se de um debate sobre símbolos, formas e significados para o debate de regras, metodologias e sistemas pelos quais se pautara a arquitetura.

Neste deslocamento repousa a crise daquela postura iniciada durante o século $\mathrm{XV}$ pelos arquitetos toscanos. É bem conhecida a relação de referência que durante o século XVIII os arquitetos na Europa deram às formas do passado - como algo exótico, que poderia ser ladeado com os motivos longínquos de suas colônias. Assim como Pevsner, Zevi e Giedion, Tafuri vê que os primeiros contemporâneos faziam uma livre manipulação do vocabulário de outras épocas, esvaziando seu significado original e nele embutindo uma significação nas conveniências da época presente.

\footnotetext{
128“ A tentativa de fundar a tradição da civilização urbana de Florença com a ideologia do Renascimento clássico e com o mito universal da renovação imperial romana se sufoca assim na dúvida, no debate triste sobre hipóteses no presente dificilmente conciliáveis" TAFURI, Manfredo. Teorie e storia dell'architettura, Op. cit. p. 39.

${ }^{129}$ TAFURI, Manfredo. Projecto e utopia, Op. Cit., p.18.
} 
Nesta construção, a arquitetura das vanguardas passa a ser mais uma a enfrentar uma crise que tem sua origem no humanismo. Pouco a pouco, arma-se a construção do cenário e protagonistas da performance maquinal: as vanguardas são as primeiras a dar os parâmetros de uma nova preceptiva baseada nos standards da máquina, opondo às belas artes uma pautada na estética industrial. Tafuri apropria-se da alegoria do mago e cirurgião feita por Walter Benjamin, na qual a arte tradicional é ladeada ao curandeiro mágico e a arte mecanizada ao cirurgião; enquanto o primeiro mantém um elo místico entre paciente e curandeiro, o outro simplesmente abre o seu paciente e diretamente intervém na restituição de sua saúde. A arte tradicional tinha uma ligação misteriosa com os seus apreciadores, pleno de conteúdos cultuais, enquanto a reprodução técnica se inserem mais corriqueiramente no cotidiano, no limiar do entretenimento. Tafuri deliberadamente se apropria desta passagem - que para Benjamin se referia ao cinema e fotografia - e a transpõe para a arquitetura feita pelas vanguardas. Distingue dentro delas dois procedimentos acerca da mecanização: um que adota a gama da linguagem industrial mantendo dela um distanciamento, como os procedimentos de se trabalhar com colagens, repetições e ritmos sobre o universo maquinista, tratando-a como outra natureza. Nesta tendência, os arquitetos nomeados são Nikolai Ladovsky e Konstantin Melnikov.

Os “cirurgiões" são os artistas que efetivamente penetram na realidade através da nova aparelhagem e buscam a partir dela novos postulados. "Não aceitando como dado externo a nova natureza industrial, eles pretendem entrar nela como produtores e intérpretes." ${ }^{130}$ Neste grupo são citados Mies Van der Rohe, Le Corbusier e Walter Gropius, os ditos 'mestres do movimento moderno europeu' ${ }^{\text {'131. }}$.

A pré-fabricação, os componentes articulados e fragmentados montados em obra, a padronização de peças, a mecanização do canteiro são colocados pelo autor romano como os procedimentos novos que equivalem na arquitetura à reprodutibilidade técnica de imagens pela lente fotográfica. Resta clara a contraposição que o autor estabelece entre os dois arquitetos da vanguarda russa e os três centro-europeus: os primeiros são ditos "arquitetos-magos" na medida em que operam com a nova formatividade industrial como símbolos exteriores, articulam a

\footnotetext{
${ }^{130}$ TAFURI, Manfredo. Teorie e storia dell'architettura, Op. cit. p. 42.

${ }^{131}$ Cf. DAL CO, Francesco e TAFURI, Manfredo. Arquitetura contemporanea. Milão: Electa, 1976.
} 
eloquência dos grandes volumes a maneira dos grandes silos, do jogo com as aberturas, sem considerar de fato as medidas e articulações do processo industrial na sua força de inserção na práxis. Faltou a estes arquitetos, segundo Tafuri, penetrar na própria indústria, dominar seus meios para revolucionar, através das fábricas, o próprio modo de se fazer arquitetura e intervir nas cidades. $O$ enfrentamento da aparelhagem, no entanto, é feita pelos arquitetos atuantes na Alemanha e França, durante o entreguerras. Entrar na pré-fabricação do canteiro e dele extrair uma nova lógica de relações, um jogo novo de significados.

Esta arquitetura tinha uma clara pretensão urbanística: busca criar uma nova ordem maquinal como parte de um amplo projeto de uma nova cidade feita otimizando as novas relações de produção e consumo. Tafuri refere-se principalmente às experiências do Neue Bauen alemão, que efetivamente viabilizam desenhar bairros inteiros tendo o princípio da reprodutibilidade como matriz, tecendo uma relação entre arquitetura pré-fabricada e cidade:

Do elemento standardizado à célula, ao bloco único, à Siedlung, à cidade. A cultura arquitetônica entre as duas guerras impôs com excepcional clareza e coerência esta cadeia de montagem. ${ }^{132}$

Fragmentação de peças e sua articulação na produção final de uma obra para as massas: a cidade é em si uma grande derivação da aparelhagem na arquitetura. Em "Por uma crítica...", Tafuri procura demonstrar como o taylorismo tem seus ecos também nas postulações estéticas das vanguardas. A passagem do componente préfabricado para a cidade pode ser lida então nos termos de uma leitura benjaminiana: para Tafuri, as casas industriais, as infraestruturas mecanizadas, seriadas e articuladas de maneira ampla para desenhar uma cidade industrial, são a virtualidade análoga à reprodutibilidade técnica na arquitetura.

Já se tem nesta construção, in nuce, a tal condição de limiar entre arte e vida presente no campo da performance. Pode-se intuir que Tafuri continua trabalhando à

${ }^{132}$ TAFURI, Manfredo. "Per una critica dell'ideologia architettonica", Op. cit. p. 58. 
contra luz do texto de Benjamin sobre reprodução técnica, quando este escreve sobre a questão do ator e do enuviamento de sua performance diante da câmera:

Na melhor das hipóteses, a obra de arte surge através da montagem, na qual cada fragmento é a reprodução de um acontecimento que nem constitui em si uma obra de arte, nem engendra uma obra de arte, ao ser filmado. Quais são esses acontecimentos não-artísticos reproduzidos no filme?

A resposta está no forma sui generis com que o ator cinematográfico representa seu papel. ${ }^{133}$

O aparelho, segundo Benjamin, fragmenta as diversas atuações do ator, o que o leva a ter como produto final uma imagem de seu corpo e de sua voz desprovida de lastro em uma real performance. A montagem que destitui o sujeito do ator é análoga na construção de Tafuri da cidade como aparelho, que reduz toda relação entre seus habitantes em termos objetivos preestabelecidos: falar de 'cena urbana', portanto, é um desdobramento residual de tal consideração benjaminiana: o rompimento com as preceptivas, a legibilidade formal dos prédios e a própria implantação dos conjuntos habitacionais alemães, como ilhas de ordem praticamente autônomas do tecido urbano colaboram para esta impessoalidade.

Diante deste impasse na arquitetura, Tafuri no princípio dos anos setenta decide de analisar diretamente o teatro contemporâneo. No artigo "A cena como cidade virtual", o autor italiano busca como esta forma de arte expressa as angústias da vida nos grandes centros. Sem surpresas, aponta como os diretores de teatro da época possuíam preocupações símiles àqueles enfrentados pelos arquitetos acerca da sociedade de massa; diante de uma crise da experiência, o teatro surgira como "recuperação de uma catarse coletiva: como uma porção de espaço desalienado."

\footnotetext{
133 "BENJAMIN, Walter. "Das Kunstwerk im Zeitalter seiner technischen Reproduzierbarkeit". Tradução para o português "A obra de arte na era de sua reprodutibilidade técnica". In: Magia e técnica, arte e politica. São Paulo: Brasiliense, 1996, p. 178.

${ }^{134}$ TAFURI, Manfredo. La sfera e il laberinto. Op. cit. p. 126.
} 
Uma primeira corrente busca exaltar e dar parâmetros à performance maquinal, como as experiências das vanguardas futuristas, que terão a pretensão de contrastar cidade e cenário. Tafuri cita o manifesto de Marinetti (com Settimelli e Corra), sobre o teatro sintético futurista, cujo principal recurso expressivo adviria "do real que vibra em nosso redor, assaltando-nos com rajadas de fragmentos de fatos combinados entre si, engrenados uns com os outros, amontoados, caotizados." ${ }^{135}$ A catarse se traduz em surpresa: agora, é preciso surpreender, emulando a multiplicidade inesperada dos choques no cotidiano. As vanguardas dadaístas e o construtivismo russo seguem caminhos comuns no esforço de representar a atuação moderna como diante de uma revolta de objetos. Diante das máquinas na cidade, da aurora do design, justamente a metrópole, como somatório de peças, é a hostil estrutura que aparece como opressora dos atores.

Precisamente Maiakovsky titula sua primeira peça teatral “A rebelião dos objetos”. Estamos em 1913, e ante aquela alegórica rebelião, ao poeta não lhe resta outra coisa senão encarregar-se das lágrimas caricaturais da bumanidade dolorosa. Mas em 1918, Misterija-Buff demonstra que no pais do socialismo realizado as coisas, animadas, reconciliaram-se com os homens. Mas com uma condição: que o bomem seja um "impuro". 136

Esta corrente eventualmente se desprende do cenário e da necessidade de uma estrutura de mediação: o teatro de estímulos e chocs bem pode ser lançado diretamente sobre a cidade mesmo. Assim, Eisenstein passa a fazer peças nas ruas e abandona assim a cenografia. Por outro lado, uma corrente de diretores se impõem como contraponto às posturas maquinais, trabalhando efetivamente em uma re-significação do cenário. Se o teatro é espaço de desalienação, este deve refletir-se na legibilidade do corpo humano, de seus movimentos e seus recursos expressivos - seus movimentos deveriam recuperar o sentido de experiência. "Em lugar de uma confusão de

\footnotetext{
${ }^{135}$ Idem, p. 129.

${ }^{136}$ Idem, p. 131.
} 
linguagem, portanto, um cena antialusiva e uma exaltação dos artistas de variedades: estes 'animais dramáticos' que souberam ganhar a batalha contra a literatura conservando no cenário o valor essencial do drama."137

De Fuchs escrevia sobre o cenário como um 'pano de fundo sem perspectiva', sem ilusionismos; Adolphe Appia prediz um "espaço livre capaz de acolher as manifestações mais variadas da vida social e artística (...) lugar por excelência onde a arte dramática florescerá, com ou sem espectadores." 138

Existe, portanto, catarse resolvendo a cena de forma sintética. As hipóteses de De Fuchs e Appia possuem uma abordagem mimética do fenômeno das metrópoles, mas resguardam ainda o teatro como espaço de limiar. A recuperação do sujeito parte das montagens e dos dilemas dos grandes centros, preservando seu caráter de espaço autônomo, carregando em si a matriz da contestação do comportamento maquinal. “No teatro”, escreveu Tafuri, “os 'opostos' que na cidade permanecem inconciliáveis, recompõem-se em unidade, graças ao foco rigoroso imposto à visão." ${ }^{39}$

Surge, neste sentido, uma performance que se desdobra para conseguir construir uma reconciliação entre homem e cidade. ${ }^{140}$ Vimos como na performance maquinal a cidade, como uma "máquina”, subsume os atores à sua participação operacional no drama da produção. Para tanto, é necessário que se esvazie qualquer senso histórico de sua atuação, na medida em que qualquer tentativa de se reestabelecer a interlocução com a tradição seria invariavelmente trazer a tona um devir, e com ele todo o rol de transformações que não cabem dentro dos esquematismos da produção industrial. Pode-se inferir que Tafuri subscrevia-se à visão de Giulio Carlo Argan segundo a qual a industrialização tem uma lógica de saltos e sucessões estranho à história, sendo que as duas atividades disputam sobre o

\footnotetext{
${ }^{137}$ Idem, p.127 e ss.

${ }^{138}$ APPIA, Adolphe, citado por TAFURI, Manfredo. La esfera y el labirinto, Op. cit. p. 128. Grifo do autor.

${ }^{139}$ TAFURI, Manfredo. "Il luogo teatrale dall'umanesimo a oggi”. Op. cit. p. 26.

${ }^{140}$ Podemos ver neste desdobramento ecos da leitura benjaminiana de teatro. Esta é uma arte aurática por essência: a interpretação depende da presença e de uma ligação entre espectador e ator. "A representação mais lamentável do 'Fausto', apresentada por um teatrinho de província, tem, relativamente a um filme sobre o 'Fausto', a vantagem de estar em concorrência ideal com a estreia em Veimar." Qualquer montagem de Fausto, por mais simplória que seja, atualiza aquela primeira em Veimar. Assim como as relações de tempo possuem um devir, as atuações teatrais também são marcadas por esta determinação. Interpretar Mefistófeles é ser Mefistófeles. "A aura que se manifesta em torno de um Macbeth não pode ser separada da que, para um público ao vivo, rodeia o ator que representa aquele personagem." In: BENJAMIN, Walter. "A obra de arte na era de sua reprodutibilidade técnica" Op. cit. p. 79 e 92.
} 
destino das cidades contemporâneas ${ }^{141}$. Cientes deste poder do senso histórico, antitético às deambulações estéreis maquinais, algumas novas correntes buscam reaver do teatro o caráter de atualização: uma narrativa que pusesse em circulação novamente os dilemas universais da peça. Este aspecto de sua filosofia reverbera em um ponto maior de sua obra geral, que é toda força da atualização histórica que reestabeleceria o elo com a tradição, história e ao devir.

Referir-se na cidade à posição dos seus habitantes como uma atuação tem dupla significação: além da primeira, maquinal, de peças da cadeia de produção, surge uma outra que lhe faz oposição, que busca recuperar antigas tradições da vida cívica: não à toa, as discussões sobre a cidade contemporânea são para Tafuri pautadas por uma contraposição ao tecido histórico ${ }^{142}$. Tal pontuação não é das questões de desafogo populacional e preservação patrimonial, mas também da possível perda dos significados sedimentados na forma dos bairros antigos. Tafuri comenta acerca da consciência histórica, que "representou uma 'recuperação', um reatar com uma cultura que só artificialmente e por polêmicos movimentos práticos foi considerada quebrada." ${ }^{143}$ Atento para que tal recuperação não seja dada em termos estritamente preservacionistas, lança como indagação, em seu artigo intitulado "O problema dos centros históricos no interior da nova dimensão citadina":

O que realmente condiciona a "bistoricidade" dos antigos
tecidos? Algum elemento vital lhe cria hoje um
insubstituivel valor social?
Os valores de espelho diagramático de todos os valores
tradicionais de uma cultura e de um povo, nas suas lutas, nas
suas esperanças, até mesmo suas derrotas, serão pesquisados

141 "É certo que uma vivência tecnológica vem acompanhando, em todo o seu curso, a vivência histórica; mas hoje a tecnologia se coloca como autoridade, tende a assumir uma função hegemônica e exclusiva, a realizar a sua própria utopia, a substituir o seu próprio movimento linear, inflexível, pelas curvas, pelas pausas e retomadas do modo histórico. O ponto problemático não é a origem e a natureza da tecnologia, mas o fato de por-se hoje como utopia realizada ou realização possível de todas as utopias. Portanto, como anti-história." ARGAN, Giulo Carlo. Progetto e destino. Milão: Il Saggiatore, 1977, p. 17.

${ }^{142}$ PICCINATO, Giorgio, QUILICI, Vieri, TAFURI, Manfredo. "La città territorio: verso una nuova dimensione", In: Casabella continuità, n. 270, 1962, pp. 16-25.

${ }^{143}$ TAFURI, Manfredo. "Il problema dei centri storici all'interno della nuova dimensione cittadina", Op. cit. p. 27. 
naquele modelo metodológico que reconhecemos como exigência concreta para o nosso agir no presente. ${ }^{144}$

Tafuri propunha que na aproximação com os centros históricos, os planejadores tenham como produto a confecção de um "espelho diagramático" a partir de aspirações tão pouco palpáveis da cidade, como suas lutas e esperanças. A tarefa de projeto, para o autor romano, era já muito ligada à atualização dos significados antigos, como modo de ver nos centros históricos "não um patrimônio morto, mas o horizonte mesmo de sua história, para se viver e consultar dia após dia."145

Existe um interesse pelos resquícios da vida nas cidades: Tafuri busca os significados perdidos em alguns hábitos que se mantêm apesar de todo o ritmo destrutivo da metrópole industrial às tradições. Sua busca pelo centro histórico nada mais é do que a recuperação de um cenário onde as peças não eram preestabelecidas dentro dos termos de um jogo de estímulos, choques e automatismos. Não à toa, buscará em textos como "Veneza e o Renascimento", ver a importância dada a virtudes como a prudência na gestão da República do Vêneto, na medida em que elas revelam determinados modos como se historicamente atuou naquela cidade. Ali, a sua investigação sobre os edifícios construídos no século XVI são vistos como um conflito que no plano da forma dos edifícios, está sempre pautado pelas virtudes que neles se deveriam exaltar. A "prudência" é importante pelo modo como ela balizou uma longa discussão que ultrapassou gestões do Senado acerca das novas procuradorias na Piazza di San Marco - até que se escolheu por fazê-las em uma solução e idêntica às procuradorias antigas.

Cidades contemporâneas auspiciam uma utopia do mesmo modo as cidades históricas ostentam cada uma sua série de intenções e 'valores tradicionais' que se impõem nas atuações da cidade.

Essa pretensão ultrapassa a contingência para a qual o projeto de arquitetura é construído. Em "Teorias e história” o autor deixa clara tal interpretação dizendo que "A arquitetura é sempre construção de uma utopia." ${ }^{146}$ Poder-se-ia ler esta passagem em uma chave exclusivamente pragmática, ou até mesmo negativa, como se todo projeto

\footnotetext{
${ }^{144}$ Idem, p. 28.

${ }^{145}$ Idem, p. 30.

${ }^{146}$ TAFURI, Manfredo. Teorie e storia dell'architettura, Op. cit. p. 241. Grifo de Tafuri.
} 
tivesse um âmbito irrealizável de intenções. Entretanto, esta frase sintetiza a parte mais positiva presente nos seus ensaios do final dos anos sessenta - tida comumente como a época mais radical de seu comprometimento com o marxismo - e a que mais permite se entrever alguma continuidade entre seus trabalhos de juventude com sua obra madura. Pois, parágrafos antes, Tafuri escreveu que "Os conteúdos da linguagem arquitetônica compreendem significados derivantes de disciplinas estranhas ao projeto arquitetônico, mas que neles não se exaurem.” E define: “A ideologia subsumida nas obras arquitetônicas é sempre, em substância, uma visão do mundo que tende a se colocar como construção do ambiente humano.” ${ }^{147}$

Não existe arquitetura sem ideologia. Se em "Por uma critica..." ela aparecia em termos de denúncia acerca de seus usos práticos, em uma carta escrita nos anos oitenta para Joan Ockman, ela fica mais complexa:

"Eu não acredito que a ideologia seja um inimigo. Isto que chamamos ideologia nós poderíamos chamar - seria melhor - representação..."148

Tornando a ideologia mais uma forma de 'representação', a cidade se torna amplo espaço para ser lida não em aspirações pontuais, mas de modo integral: tendo que os discursos se fragmentam e se enfrentam na cidade, e tendo as vanguardas definitivamente subvertido na raiz tal caráter retórico das construções, cenário e protagonistas se debatem para definir o caráter da peça que se atua na metrópole. $\mathrm{Na}$ resposta à Ockman, Tafuri procura ladear seus estudos sobre o Renascimento eminentemente calcados na questão da representação - com os da contemporaneidade, ligados às aspirações utópicas dos arquitetos do final do XIX até

${ }^{147}$ Idem, p. 241. Grifo de Tafuri.

${ }^{148}$ TAFURI, Manfredo, citado por OCKMAN, Joan. "Venice and New York". In: Casabella, n. 619620, p. 67. Grifo do autor. Essa passagem é a mais eloquente, mas existem trechos, em obras como "A arquitetura do humanismo", que já trabalham com a ligação entre representação e ideologia: "A sua arquitetura [do humanismo] é portanto ideológica enquanto, no intervir e modificar a cidade burguesa acolhendo a lição da história, e selecionando nela arbitrariamente os aportes, coloca-se como consciência do renovado domínio da racionalidade humana sobre a natureza. Brunelleschi pode conversar de igual para igual com o antigo, mas contemporaneamente, introduzindo na cidade medieval os seus objetos espaciais como reverberadores de valores racionais, pode-se permitir reconhecer a própria continuidade cultural com algumas expressões do romanico toscano. A história, para ele, não é ainda um tanque de cânones abstratos", TAFURI, Manfredo, L'architettura dell'umanesimo, Bari: Laterza, 1969, p. 318. Grifo de Tafuri. Cf. TAFURI, , Manfredo, "Le strutture del linguaggio nella storia dell'architettura moderna: i parametri di controllo", In: ROSA, Federico. Progetto e critica dell'urbanistica moderna, Op. cit., pp. 296-322. 
as megaestruturas dos anos sessenta. A palavra representação aparece no primeiro plano dos textos do italiano sobre o Renascimento ao final dos anos setenta - na carta para Ockman temos um historiador de carreira consolidada fazendo uma síntese retroativa de seu trabalho. Entretanto, durante os anos sessenta e princípio dos setenta já temos ecos precários deste elo entre ideologia e representação. Em "A arquitetura do humanismo", uma obra concomitante com "Teorias e história”, é possível ver que a grande revolução engendrada pelo Renascimento é a criação de um código linguístico capaz de dar conta da ambiguidade entre vida urbana presente e a construção de uma perspectiva utópica de cidade. "Diante das escatologias e às expectativas milenares do medieval," contrapõe Tafuri, “o humanismo reafirma o caráter concreto, socialmente e economicamente determinado da vida urbana e dos desenvolvimentos citadinos. A 'cidade perspectiva' de Brunelleschi e Alberti é a cidade real, com tuda a complexidade das suas estratificações históricas..." ${ }^{149}$

O Renascimento cria um novo "código linguístico" que traz na sua retomada do clássico um restabelecimento do senso histórico, em contraposição à visão milenar de mundo comumente atribuída ao homem medieval. Este restabelecimento, o autor se esforça em mostrar no "Teorias e história", é ideológico na medida em que lança mão de uma invenção do passado e de uma utopia para a cidade futura (as cidades ideais como extensão das medidas humanas). Tal conteúdo, entretanto, está intimamente ligado ao nexo entre modernidade e contemporâneo: para Tafuri, ali está determinada um "novo modo de intervenção sobre a cena das ações humanas, destinado a dominar por mais de quatro séculos a arte ocidental." ${ }^{150}$

Ao ladear ideologia à representação, Tafuri clama por uma complexidade maior no estudo da história do contemporâneo, como uma dialética entre projeto realizado e 'à espera'. A abertura de um caminho teórico que permita dar espaço para que se veja de modo compacto a experiência urbana não poderia existir sem esta aproximação feita entre teatro e arquitetura: compõe-se no quadro geral dos estudos de Tafuri com a mesma importância que as utopias inviáveis, na medida em que ambas são modos de se entrever as intenções da cidade menos ligadas à contingência.

\footnotetext{
${ }^{149}$ TAFURI, Manfredo. L'architettura dell'umanesimo, Op. cit. p. 309.

${ }^{150}$ Idem, p. 20.
} 
A chave negativa acerca do contemporâneo presente em "Por uma crítica" - e em toda a obra do autor, - não é tanto no caráter ideológico da arquitetura de seu tempo quanto na sua vontade de mudez.

Em "A cena como cidade virtual", Tafuri encerra o texto falando do Pavilhão de Barcelona, dizendo ser este o mais sofisticado 'teatro' que as vanguardas poderiam conceber:

Naquele espaço, lugar de ausência, uma vez compreendido o
negativo da metrópole, o homem, espectador de um espetáculo
"total", pois inexistente, se vê obrigado a uma pantomima
que reproduz o vagar pelo labirinto urbano de seres-signos
carentes de sentido, experimentado cotidianamente por ele. ${ }^{151}$

Nesta análise a suspensão da cena é concomitante com uma suspensão dos significados - a metrópole não se apresenta como negação de qualquer cenário, mas como a citação de sua ausência. Do mesmo modo que o cenário no teatro de vanguarda se torna supérfluo diante da atuação na cidade, a própria forma urbana se desprende do caráter significativo dos tais "valores tradicionais" a que Tafuri se referira. A discussão sobre performance, na medida em que sempre recai em um debate entre interlocução e senso histórico, é irremediavelmente pautado pelas significações. Significação entendida aqui como a legibilidade dos valores e tradições implícitos nas formas dos edifícios e dos tecidos urbanos. Se na construção do autor italiano a cenografia é ladeada à cidade, ambas se encontram no plano da forma ${ }^{152}$ : desde seu texto sobre a ideologia na arquitetura, Tafuri ampara-se na interpretação de que as vanguardas foram as primeiras a destruir tal ligação entre forma e significação. Tal desprendimento o autor romano via já nas obras de Piranesi, especialmente na sua proposição para o Campo Marzio, onde as ordens clássicas e os vocabulários postulados durante o século XVIII são insistentemente repetidos e articulados em uma estrutura sublime, onde "nenhum esforço subjetivo pode mais recuperar uma

${ }^{151}$ TAFURI, Manfredo. La esfera y el laberinto, Op. cit. pp. 144 e ss. Grifo do autor.

${ }^{152}$ TAFURI, Manfredo. "Le strutture del linguaggio nella storia dell'architettura moderna", Op. cit. p. 297. 
autenticidade perdida para sempre." ${ }^{153}$ Piranesi é considerado o primeiro "vanguardista" na medida em que é o primeiro a efetuar um ataque profundo à forma como bastião de significação.

As "primeiras" vanguardas, deste modo, não tinham a pretensão inicial de retirar todo o significado da forma: as rupturas elaboradas por Piranesi em seu Campo Marzio eram contingenciais: é só a partir das vanguardas alemãs (advindas principalmente do Neue Sachlichkeit) e francesas (capitaneados pelo purismo de Le Corbusier e Ozenfant) se ocupariam por positivar tal procedimento impondo uma 'nova ordem' onde os standards industriais se tornariam representação do plano, matriciais para a formação de uma nova estética e novos e universais significados. Tal perda, a metrópole como cenário ausente para uma peça alienada, advêm no momento em que ideologia e arquitetura se separam - O Pavilhão de Mies Van Der Rohe aparece como grande obra que ao princípio dos anos trinta, revelava a defasagem que a arquitetura sofria em relação ao desenvolvimento das cidades e a necessidade de se construí-las segundo um plano global de organização ${ }^{154}$.

Entretanto, mais do que um problema de reorganização do capital, ocorre, segundo o autor, um problema de mudez da arquitetura com as suas mais antigas contribuições aos princípios estético-culturais de uma sociedade. "É talvez necessário fazer o discurso mais preciso acerca da relação entre arquitetura e instituições... ou seja, o que se fechou foram as vias da linguagem como comunicadora de mensagens, que é o discurso humanista” ${ }^{155}$, dizia Tafuri em 1976, deixando clara que suas opiniões sobre o contemporâneo têm uma forte motivação a partir de suas pesquisas sobre o Renascimento.

Partindo de um problema de representação, humanismo e contemporâneo partem do mesmo dilema: questão de forma, onde tem-se a ideia de que a cidade seria tão ligada em seus significados quanto aos seus habitantes, de modo análogo que um cenário para os atores.

\footnotetext{
${ }^{153}$ TAFURI, Manfredo. "Per una critica dell'ideologia architettonica", Op. cit. p. 46.

${ }^{154}$ Para Tafuri, Mies Van der Rohe é o arquiteto que leva até as últimas consequências tal cisão entre matéria, espaço e significados. Cf. DAL CO, Francesco e TAFURI, Manfredo. Architettura Contemporanea. Op. cit.

155 TAFURI, Manfredo, citado por HOEKSTRA, Titia. Building vs. Bildung: Manfredo Tafuri and the construction of a bistorical discipline. Op. cit. p.29. Na fala, Tafuri polemizava com Aldo Van Eyck, durante a Bienal de Veneza de 1976.
} 
A partir do final dos anos setenta, os textos de Tafuri sobre o Renascimento passam a ter um ponto de partida constante, na categoria "representação". O tal novo código linguístico introduzido pelos humanistas toscanos tem a sua diferenciação daquele gótico especificamente por ser "completamente representativo"156. A interpretação de Tafuri sobre forma baseia-se amplamente no élan muito estreito entre homem, transcendência e geometria presente no humanismo: "Para o teatro humanístico, valem as teorias aristotélicas sobre a unidade de tempo e lugar, paralelamente ao novo impulso dado aos estudos vitruvianos e à hipótese de unidade do espaço arquitetônico como reflexo da racionalidade do cosmo e do microcosmo humano."157

Enquanto no contemporâneo cena e cidade são concomitantes pela ausência de significado, durante o humanismo ocorre justo o oposto, uma vontade de sintonia completa entre estes dois termos. "Não os conteúdos, portanto, são novos, mas o processo - matemático e verificável - que permite a sua formalização em uma sistemática 'por em imagens' o mundo." 158 O humanismo, segundo Tafuri, é um período sobretudo conflituoso e cheio de jogos de poder que acontecem sob o jugo de uma intensa procura pela forma que teria uma eloquência tamanha, universal e imperecível. $\mathrm{Na}$ medida em que os períodos posteriores, o Maneirismo, entra como uma contestação da existência mesma de uma legibilidade tão universal: os ataques de Michaelângelo, Peruzzi e outros cinquecentescos não se focam na desarmonia entre razão humana e manifestação divina, mas na difícil subsunção de uma tratadística que lhe faça jus; trata-se sobretudo de uma crise de representação:

É em certo sentido o culto da razão que é exaltado e retomado, mas dissociado de todo objeto ou fim que não se resolva nele próprio: nesta situação a inteligência racional se encontra liberta de si, mas em um limbo de bipóteses todas válidas e todas verificáveis - enquanto não podem senão se autoverificar - e a coisa mais grave e inquietante: intercambiáveis. Então o passo que porta do racionalismo ao

${ }^{156}$ TAFURI, Manfredo. Ricerca del Rinascimento, Op. cit. p. 20.

${ }^{157}$ TAFURI, Manfredo. "Il luogo teatrale dall'umanesimo a oggi", Op. cit. p. 25.

${ }^{158}$ TAFURI, Manfredo. Ricerca del Rinascimento, Op. cit. p. 20. 
irracionalismo, do tecnologismo ao desfile cenográfico, do colecionismo como questão de gosto pelo capricho e o bizarro, $d a$ ciência da ironização à ironização da ciência $\mathrm{em}$ uma palavra, é tão rápida que aparece frequentemente resolvido em uma presença de opostos que se anulam, afinal. ${ }^{159}$

Nesta interpretação feita pelo jovem Tafuri, em 1966, aparece uma matriz recorrente na sua carreira, não obstante as vicissitudes radicais que aconteceriam na sua obra. Seus estudos dão ênfase ao arco que liga humanismo à contemporaneidade. Este período inicial, esta origem estabelecida pelo autor é o ponto onde representação e forma eram pensados de modo compacto. No maneirismo, e sobretudo no barroco, surgem contraposições a esta universalidade, quando recorre-se a ilusionismos espaciais e deformações das tratadísticas que deliberadamente intendem particularizar princípios supostamente universais. ${ }^{160} \mathrm{~A}$ crise dos significados construídos - e do problema que isto causa na experiência urbana - são partes desta grande crise da representação nas quais a época moderna serve de contraposição ao contemporâneo: não importa o quanto a busca pela representação tenha sido posta em crise desde o século $\mathrm{XV}$, a passagem deixa clara que o irracionalismo, colecionismo e 'desfile cenográfico' são afinal o lado oposto da moeda da harmonia entre representação e preceptiva. Os temores de Tafuri acerca do contemporâneo recaem no fato de que este foi o único momento da história em que a forma prestou-se a levar até as últimas consequências a destruição e redenção dos significados da cidade - segundo Tafuri, durante o Renascimento, Maneirismo e Barroco, não importavam as crises acerca do que poderia passar por 'universal', as representações sempre foram objeto de ponderação, busca fulcral da arquitetura.

Ao escrever "Por uma crítica...", Tafuri utiliza a palavra 'ideologia' como termo que resolve como aquela nova estética que adviria de um elo com o aparelho poderia ter uma teleologia materialista, da "cidade de homens livres" ou das quatro funções previstas na Carta de Atenas. As construções históricas de Tafuri consideram o tempo entre a modernidade e contemporâneo como algo eminentemente próximo - o autor

${ }^{159}$ TAFURI, Manfredo. Il manierismo nel '500 europeo, Op. cit., p. 65.

${ }^{160}$ TAFURI, Manfredo. "Le strutture del linguaggio nella storia dell'architettura moderna", Op. cit. p. 302. 
romano utilizava mesmo o termo "monádico" benjaminiano para se referir à história. Entretanto, a separação de termos ideologia e representação mostram uma parte de sua contribuição historiográfica onde existe sem dúvida uma aproximação, mas com um caráter ambíguo: pode-se ver concomitantemente uma ruptura entre tempos: com o século XVIII, através das fantasias de Piranesi e das investidas do urbanismo iluminista contra a cidade preexistente, a representação entra em crise de um modo diverso daquele da modernidade - no limite, ela se torna falso julgamento da consciência. "Por uma crítica..." pertence a uma senda de textos onde o Humanismo aparece de longe, na qual a questão contemporânea tem com ele um hiato. Assim, sua carreira divide-se durante esta década entre trabalhos sobre o Renascimento (como "Via Giulia", desenvolvido e escrito em Roma), e uma ampla gama de textos sobre os contemporâneos escrito no seu departamento em Veneza (“A cidade americana”, "Projeto e utopia”, “Arquitetura contemporânea”). $\mathrm{Na}$ questão da ideologia, representação e cena, Tafuri se afasta daquela prosa onde moderno e contemporâneo são simultâneas, como em "Teorias e história da arquitetura". Por este motivo, é importante notar que nas margens de seu estudo do contemporâneo - onde o grande ponto de seu interesse são as correntes das vanguardas até 1930 - justamente o que se sobressai são discussões acerca da representação e da restituição de um lugar para os códigos linguísticos. Neste tema, é preciso mais uma vez atentar para a ligação entre cena e ator: a recuperação dos significados e tradições são construções que requerem um sujeito que as retome. Dentro dos termos da performance maquinal, o ator é a massa, que na prosa de Tafuri, diferente da literatura marxista do XIX e das deambulações de Benjamin e Argan, é estéril na restituição do senso histórico. Tafuri não considerava as massas portadoras de uma força transformadora não são sujeito de uma apropriação que dê novo significado à realidade, às artes ou às cidades; na refuta em subscrever-se a crença de que as vanguardas poderiam dar às massas o estalo que lhes poria em movimento é que Tafuri se afasta realmente de Argan, Zevi, Benevolo. Sem adotar este ator contumaz nos círculos de esquerda, para Tafuri o problema de reabrir o debate da forma e representação invariavelmente deve passar pela retomada do protagonismo histórico.

Em um artigo recente, Andrew Leach enfrenta o interesse de Tafuri na figura de Borromini e no universo barroco. Neste estudo, amparou-se nas transcrições de 
aula de Tafuri do curso de 1978 sobre Francesco Borromini e a crise do universo humanístico, compiladas por Luca Scappin, antigo aluno do autor romano. O curso começava com duas aulas nas quais a arquitetura aparecia de modo tangencial: as palestras eram focadas no estudo da tese acadêmica de Walter Benjamin "A origem do drama barroco alemão". Em uma leitura dos temas, Leach conclui que Borromini foi construído, na prosa de Tafuri, como uma figura ajustável ao intelectual melancólico de Benjamin. Para Leach, Borromini “personificava uma atitude critica que Tafuri entende, seguindo suas leituras de Benjamin, soando verdadeiro ao seu próprio entendimento de crítica dentro de historiografia e não por acidente, mas por uma recuperável ressonância entre desenvolvimentos intelectuais e artísticos nos séculos XVII e XX." ${ }^{161} \mathrm{Na}$ crise da forma, portanto, tem-se o surgimento de uma expressão visceral nos textos de Tafuri: a sua entrada no Barroco teve sempre Borromini como um protagonista de seus estudos ${ }^{162}$ - em seus textos, o autor romano o coloca como figura excelente daquela angústia vivida pelo barroco, onde tudo é fragmento perdido.

Interessante atentar que este curso mostra uma virada nos temas letivos dos cursos de história do arquiteto: trata-se de uma exposição personalista, calcada diretamente na relação entre um autor com dilemas gerais. "Francesco Borromini e a crise do universo humanístico": o autor italiano nomeou um personagem principal para os seus cursos. Um ano antes, no curso sobre Viena, as aulas são separadas por personagens (Loos, Hoffmann, Mahler), mas o curso em si tem várias exposições com temas gerais. Para se estudar o barroco, entretanto, era preciso partir da personalidade de Borromini. Mais do que um fato isolado, esta estrutura passou a ser utilizada amplamente por Tafuri até ministrar seu último curso em 1994: Piranesi (1980-81), Raffaello (1984-85), Giulio Romano (1985-86), Bramante (1986-87), Giuliano da Sangallo e Jacopo Sansovino (1988-89), Francesco di Giorgio e Baldassare (1989-90) e Leon Battista Alberti (1992-93).

O único curso anterior ao de Borromini especialmente focado em um personagem foi feito no princípio da carreira de Tafuri em Veneza, no seu segundo ano no IUAV, em 1968-69. O nome do curso era tão somente "Le Corbusier", sem

\footnotetext{
${ }^{161}$ LEACH, Andrew. "Francesco Borromini and the Crisis of the Humanist Universe", Op. cit. p. 329. ${ }^{162} \mathrm{O}$ texto de Leach é muito didático nos meandros deste interesse. Partindo do anno borrominiano de 1967, onde várias publicações foram feitas sobre o arquiteto lombardo, Leach faz uma revisão bibliográfica dos interesses de Tafuri sobre o barroco e como a figura de Borromini passa a ser central não só por uma conveniência acadêmica, mas fulcral em todos os meandros de sua obra.
} 
subtítulos. As ligações de Tafuri com este autor suíço foram alvo de atenção por dois comentadores saxônicos do autor italiano, Hélène Lipstadt e Harvey Mendelsoh, em 1994. Muito antes de existir um índice organizado das aulas do historiador romano disponível no IUAV, os dois autores escreveram o artigo intitulado "Filosofia, história e autobiografia: Manfredo Tafuri e a 'insuperada lição’ de Le Corbusier”, onde o principal objetivo era estudar uma insistência do historiador romano em sempre, nos seus mais polêmicos escritos, colocar o arquiteto da Ville Radieuse no papel principal:

"Parece que Tafuri reservou para Le Corbusier o papel de maior protagonista em seu 'drama', o que levanta a questão acerca de sua intenção geral.” Tal percepção aparece após uma constatação de que o autor romano, apesar de considerar várias correntes, sempre termina por determinar o suíço como "o único arquiteto que resta" ${ }^{163}$.

Retornar-se-á a estes personagens em breve. Por enquanto, cabe ponderar como é importante a informação divulgada por Andrew Leach, de que Tafuri nos legou duas aulas inteiras sobre o "Origem do drama barroco alemão" de Benjamin, justamente no momento em que decidiu direcionar suas aulas aos protagonistas. $\mathrm{O}$ interesse de Tafuri por Benjamin é evidente; entre 1968 e 69, o romano publicou "Teorias e história da arquitetura" e "Por uma crítica da ideologia arquitetônica", nos quais é central a presença dos termos do filósofo. Seja nas considerações sobre arquitetura industrializada ou na questão da experiência perceptiva do habitante da metrópole, ali estavam as categorias benjaminianas como "aura", recepção tátil e ótica e crise da experiência. Pode-se encontrar ainda referências a Benjamin por toda a obra do autor, sem que entretanto se encontre capítulos ou palestras nas quais ele se ocupe especificamente de seus textos. O que se pode descrever, lendo os textos de Tafuri, é que este lia Benjamin com muito mais interesse nos seus trabalhos mais engajados durante os anos sessenta, como "Sobre alguns temas de Baudelaire" e "A obra de arte...”, para durante os anos setenta trabalhar mais com os textos sobre linguagem, como "O autor como produtor" e "A tarefa do tradutor".

Tal recorrência, em si, significa muito pouco: o amplo interesse de Tafuri na filosofia contemporânea germânica foi uma constante em seu trabalho. Assim, estas

\footnotetext{
${ }^{163}$ LIPSTADT, Hélène e MENDELSOHN, Harvey. "Philosophy, History and Autobiography", Op. cit. p. 83.
} 
diferentes abordagens da obra de Benjamin são mais um traço geral do modo como o autor operava suas referências. Entretanto, elas interessam no estudo do tempo em Tafuri na medida em que sua noção de átimo está imantada no todo da contribuição de Benjamin, para quem a verdade só poderia ser vislumbrada em um instante. $\mathrm{O}$ alemão usa a imagem das chamas, o "incêndio da obra", que destrói o seu invólucro revelando em um brilho intenso a verdade que nele se ocultava ${ }^{164}$. Trabalhar sobre o “Drama Barroco...", neste sentido, mostra uma atenção a um dos textos mais atímicos de Benjamin, no qual o berlinense enfrenta a questão do modo pelo qual se busca a verdade. $^{165}$

Ambas as categorias, a história e a verdade são trabalhadas de modo particular pelo historiador italiano, e o levaria a rearticulariar os recortes de pesquisa dentro de sua estratégia intelectual, privilegiando, no lugar de uma história da arquitetura, a história do arquiteto, o protagonista do drama trágico nas cidades.

As premissas de Benjamin em seu prólogo são muito baseadas no desprendimento de apriorismos e postulações, e na esterilidade em se proceder de modo dedutivo e linear na filosofia. Em uma passagem famosa, o autor berlinense fala sobre a dificuldade do filósofo em alcançar a verdade de modo definitivo; contrapõe-se a esta "metodologia" utilizando a imagem do mosaico:

$O$ valor dos fragmentos de pensamento é tanto mais decisivo quanto menos decisivo quanto menos imediata é a sua relação com a concep̧ão de fundo, e desse valor depende o fulgor da representação, na mesma medida em que o do mosaico depende da qualidade da pasta do vidro. ${ }^{166}$

É certo que na obra de Tafuri este trânsito esteve sempre presente; os fragmentos são objeto de sua rigorosa estrutura de pesquisas filológicas, onde uma hierarquia muito bem fixada de orientadores e orientandos se pautava em levantar ao máximo documentação acerca dos seus recortes. O interessante desta passagem,

\footnotetext{
164 "BENJAMIN, Walter. Ursprung des deutschen Trauespiel. Tradução para o portugês Origem do drama trágico alemão. Lisboa: Assírio \& Alvim, 2004 , p. 17 e ss.

${ }^{165}$ Especificamente em A harmonia e os conflitos, e sobre as décadas de 20 a 60 em "Machine et memoir: a cidade na obra de Le Corbusier".

${ }^{166}$ BENJAMIN, Walter. Origem do drama trágico alemão, Op. cit. p. 15.
} 
entretanto, está no fato de que a verdade reside em nenhum dos lados da equação, mas no próprio movimento de devir do fragmento em todo, no "fulgor da representação": em 1979, enquanto ministra este curso, Tafuri está na soleira de uma virada: os anos oitenta virão e com ele todo o seu Departamento será direcionado a um foco mais pesado no humanismo e barroco. Ao mesmo tempo, em 1977 o autor tinha publicado seu depoimento historiográfico intitulado "O projeto histórico", muito ligado à questão de como se aproximar dos períodos históricos e de como relacioná-los, criando novas vias de entendimento dos significados e dilemas que unem modernidade e contemporâneo. Vimos, no entanto, como a questão da representação cinde estes dois termos históricos, o que leva a própria escrita de Tafuri a uma crise em si, na medida em que este sempre foi muito baseado na exposição de dilemas comuns, privilegiando um jogo de semelhanças e diferenças nos períodos. A leitura da "Origem do drama barroco" sintetiza uma busca tanto para introduzir o tema da representação na obra de Borromini, mas também procurar resolver uma lacuna historiográfica, das questões e como resolver este ponto de inflexão entre moderno e contemporâneo. Tafuri, cita a questão da origem presente na obra de Benjamin, como a captação de instantes do devir: "Eu, historiador, fixo arbitrariamente o meu início, e se falo de início tirei da origem qualquer halo metafísico, qualquer halo existencial, não tenho nada para além disto que estabeleço... mas como estabeleço? No seu devir, no seu ultrapassar." ${ }^{167}$

A relação entre fragmento e instante - peças soltas e angústia. Longe de qualquer nostalgia pelos significados diretos, temos uma face de Tafuri que privilegia os conflitos e as personalidades de seus interlocutores. A captação do devir legitima em Benjamin a busca por dramas 'esquecidos' pela literatura alemã , para a partir dela puxar fios soltos que diretamente podem ser transpostos para a situação contemporânea: "A origem insere-se no fluxo do devir como um redemoinho arrasta no seu movimento o material produzido no processo de gênese. $\mathrm{O}$ que é próprio da origem nunca se dá a ver no plano factual, cru e manifesto." ${ }^{168}$ Tafuri está procurando seguir um caminho análogo ao de Benjamin, cria construções históricas estabelecendo

\footnotetext{
167 TAFURI, Manfredo. "Francesco Borromini e la crisi dell'universo umanistico". Corso di storia dell'architettura 2A: Trascrizione delle lezione tenute dal prof. Manfredo Tafuri nel corso dell'anno accademico 1978/79. A cura degli studenti iscritti al corso", IUAV, p. 26.

${ }^{168}$ BENJAMIN, Walter. Origem do drama trágico alemão, Op. cit. p. 32.
} 
como estudo do devir : a aparente arbitrariedade de tempos se desfaz diante de uma pesquisa que tenta captar o movimento que no seu transcorrer remete sempre a sua origem - aqui posicionada na crise da representação, que refere-se mesmo a momentos como o das vanguardas, onde existe a passagem da representação para a ideologia.

Neste ponto de seu estudo, retoma-se o fundamento dramático que unificara cidade moderna e contemporânea, pousando seu estudo na figura do protagonista. Tafuri na sua aula passa pouco a pouco por se interessar pelos autores que aparecem no texto de Benjamin e a estabelecê-los como portadores de uma significação: "Quem é o príncipe senão a encarnação de um ser simbólico?" ${ }^{169}$ Tafuri pergunta, deslocando da forma ao sujeito a sua busca de significado. Sujeito alegórico - o próprio papel que se representa é aquele que se figura. Nas peças barrocas, segundo Tafuri, o grande protagonista é o rei, que tem "o olhar do melancólico, o olhar de quem reflete sobre a impossibilidade de decisão apesar de ter poder, portanto o olhar de quem tendo poder reflete a sua impotência na qual o objeto simbólico, tornou-se alegórico." ${ }^{170}$

É explícito o ladeamento do rei com o arquiteto lombardo, Francesco Borromini. A ligação entre séculos XVII e XX se dá na sua construção da conexão entre crítico e arquiteto. Propõe-se aqui, no entanto, que se veja a verdadeira aproximação temporal no fato de que ambos os séculos apresentam uma crise de performance: análogo ao problema da cena na cidade, onde os símbolos ausentes de significado só sustentam uma atuação maquinal, o arquiteto, melancólico e impotente é o protagonista de uma tragédia. $\mathrm{O}$ arquiteto é visto como uma figura ao mesmo tempo poderosa e sem meios para resolver a crise dos significados. Os ditos protagonistas encontram papel na história feita por Tafuri como aqueles que levam até as últimas consequências a vontade de se contrapor pela forma a sua própria crise. Em Borromini, isto vem de sua vontade de explicitar as contradições preceptivas e também pela sua arquitetura ser justamente aquela que o Iluminismo se esforçará em destruir. Em "Por uma crítica", o autor romano se esforça para mostrar que na aurora da idade da Razão, o Iluminismo tem antes de tudo um papel destrutivo:

${ }^{169}$ TAFURI, Manfredo. "Francesco Borromini e la crisi dell'universo umanistico”, Op. cit. p. 9.

${ }^{170}$ Idem, p. 12. 
"É importante frisar que a desejada abstração das teorias iluministas sobre a cidade serve em um primeiro momento para destruir os esquemas de projeto e de desenvolvimento da cidade barroca." ${ }^{171}$ A figura de Borromini, portanto, representa aquele que será destituído pela época da Razão, pelos procedimentos todos que serão descritos em "Por uma crítica", "Teorias e história" e a "Esfera e o labirinto". Mais do que Piranesi, Borromini é o grande arquiteto do devir da arquitetura dentro dos esquemas vanguardistas de mudez do símbolo. A sua luta, seu fracasso, é o que interessa Tafuri para compor um quadro da modernidade - daí efetivamente século XVII e XX se encontram. Acrescendo ao estudo de Leach sobre Tafuri e sua "escolha pela história”, podemos colocar que no outro lado, na crise das vanguardas, temos justamente um outro arquiteto que sempre foi importante para o autor romano: Le Corbusier.

Em um artigo seminal, "Machine et memoir: A cidade na obra de Le Corbusier", Tafuri conclui que o arquiteto suíço é aquele que atina para a esterilidade dos "novos significados" introduzidos pelas vanguardas após sua era de rupturas, ocasião da construção do Capitólio de Chandigarh, na Índia:

Não por acaso, Le Corbusier estabeleceu uma relação direta
entre a Mão Aberta e o Fosso da Consideração.
Estes são convites para fechar-se no ascetismo: é busca de
novas fronteiras para o espaço do dizivel. Além das tais
novas fronteiras é o urbanismo, instrumento tornado
convencional, privado do potencial catártico a ele
anteriormente atribuido. ${ }^{172}$

Para Tafuri, Le Corbusier recupera a ponta solta que Borromini deixou lá atrás, no XVII. Diante dos esbatimentos da representação, da crise da forma na arquitetura que marca as vanguardas e que se torna praticamente um tabu nos anos sessenta, somente Le Corbusier, com Chandigarh, consegue trabalhar na direção de uma recuperação do significado. O urbanismo de inspiração na Carta de Atenas

\footnotetext{
${ }^{171}$ TAFURI, Manfredo. "Per una critica dell'ideologia architettonica", Op. cit. p. 16.

${ }^{172}$ TAFURI, Manfredo. "Machine et memoir: la città nell'opera di Le Corbusier". In: Casabella n. 503, 1984, p. 50.
} 
presente em Chandigarh é visto como um lugar 'privado do potencial catártico': é mais uma cena para a atuação maquinal. O capitólio, com suas citações, seus novos símbolos e com a "Mão Aberta", lida por Tafuri como um sinal de "pare" diante da modernização, dialoga com a questão da industrialização e sua incapacidade de se prestar a qualquer atualização. A cidade moderna - a utopia construída - não permite a decantação de significados que não sejam apliques - tanto quanto, ironicamente, os interiores que Benjamin descrevera em seu "Passagens". O urbanismo moderno todo pode ser visto como um grande intérieur para o Corbusier construído por Tafuri. A mão aberta é uma tentativa outra de tornar aurática novamente a arquitetura, de poder restabelecer a ela uma autenticidade e restabelecê-la como palco de uma atuação histórica. Apesar de ter dedicado aulas para outras figuras seminais da arquitetura contemporânea, como Loos, Mies Van der Rohe, Piranesi e outros, o todo da obra de Tafuri mostra como Le Corbusier, em todas as fases de sua trajetória foi um grande protagonista do contemporâneo, para o autor ${ }^{173}$.

Em 1981, Tafuri para de falar sobre o contemporâneo em suas disciplinas. Ademais, não esconderá seu desinteresse pelo presente como tema de pesquisa. Existem várias especulações, algumas sugerem descrença, ausência de interesse, predileção pelos temas acadêmicos, mas não se lançou ainda uma hipótese que dê conta deste momento em 1978, quando o historiador romano passa a lecionar sobre personagens da história. As aulas de Tafuri e seus textos são muito diversos no estilo: enquanto seus ensaios são abertamente rebuscados e construídos como "mosaicos", suas exposições orais são claras, didáticas, como se a teoria devesse ser passada de modo transparente aos seus futuros discípulos. Assim, parar de lecionar sobre o contemporâneo significa parar de querer formar arquitetos a partir dos dilemas imediatamente ligados com o presente. Não deve ser fortuita a coincidência entre estas duas viradas didáticas: talvez o desinteresse de Tafuri pela contemporaneidade seja simplesmente pela ausência de protagonistas fortes o suficiente para atualizar dilemas de forma global. Mais do que descrença, ausência de temas e de dramas narráveis. A crise de Tafuri é literária: faltam-lhe personagens no presente que tenham fôlego de sustentar suas obras. História da arquitetura como tragédia, protagonismos

\footnotetext{
${ }^{173}$ Nos seus estudos do humanismo e barroco, o leque foi mais variado. Existem, além de Borromini, textos sobre Alberti e muitos outros, como Raffaello Sanzio, Baldassare Peruzzi etc.
} 
que além de amalgamar períodos históricos, tornaria coerente construtor e construído, são procedimentos fortes na obra de Tafuri, que aparecem eminentemente nos textos sobre a modernidade. O contemporâneo, o "mau presente" ao qual se referia o autor $^{174}$, é aquele onde prevalece as massas anônimas das quais não se sobressai um contraponto. Nem trágica é a contemporaneidade; é muda, na medida em que faltam figuras que possam performar a tragédia que é a busca da arquitetura de expressar a vontade de se representar um senso universal de história, uma via de contestação.

Assim pode-se ler o quadro geral da performance para o historiador romano: a cenografia é um pretexto para que se veja de modo integral a cidade, mas também o espaço onde se pode criar a imagem adequada do arquiteto, como o protagonista de um mundo que cai em ruínas instantaneamente. Nesta compactação, é oportuna a ligação com a tragédia, onde o clímax lutuoso termina com uma concomitância entre derrota do protagonista e do seu reino. Existe no autor romano uma dialética muito presente entre obra e pessoa, entre cena e atuação. A pessoa, o protagonista, tem até mesmo uma certa feição metalinguística: afinal, o crítico também é aquele que caminha como um equilibrista sobre a corda. Se no campo prático Tafuri foi lembrado por cindir a figura do arquiteto profissional do historiador, é certo que na sua análise acerca das cidades e cena, os dois estão unidos nesta condição de impotência onisciente, que invariavelmente lhes lançam às suas ruínas.

Walter Benjamin aparece como referência nos textos de Tafuri pela sua ligação muito estreita entre performance e representação ${ }^{175}$ : se muitas categorias benjaminianas aparecem na prosa de Tafuri, elas eminentemente recaem na questão de um público e de um espectador. Se o único documento em que o autor romano dedica explanações sobre o autor berlinense são aulas sobre o "Origem do Drama Barroco Alemão", tal fato é completamente coerente com o seu ponto de concomitância maior com o filósofo: o interesse em ver nos fragmentos e nas obras menores indícios de um mundo como um estojo, onde tempo e espaço são monádicos

\footnotetext{
174 “Temo sempre que julgues mal o meu compromisso: não falarei em Urbino, mas não por desinteresse pelo que ocorre. Permaneço absorto, não destacado, acerca do 'mau presente'. Busco no ontem 'inícios' e 'razões' (...) isto me toma de tal modo que não posso falar por enquanto senão de pequenos fragmentos antigos." Correspondência de Manfredo Tafuri a Giancarlo de Carlo datada de 2 de julho de 1983. Disponível no Archivio progetti do IUAV.

${ }^{175}$ Cf. PRIMAVESI, Patrick. "The Performance of Translation: Benjamin and Brecht on the Loss of Small Details". In: TDR, v. 43, n. 4, "German Brecht, European Readings", inverno de 1999, pp. 5359.
} 
e portadores de uma potencialidade redentora muito forte. Susan Sontag, ao comentar a prosa de Benjamin, escrevera que "Os temas recorrentes de Benjamin são, tipicamente, meios de espacialização do mundo: por exemplo, as idéias e as experiências vistas como ruínas. (...) No tempo, somos apenas o que somos: o que sempre fomos. No espaço, podemos ser outra pessoa."

Em uma entrevista feita em 1986, Tafuri declarara que a "massa dos arquitetos" não deveria se preocupar, mas simplesmente "fazer arquitetura". Dizia que se existisse uma palavra final, uma epifania última, ela "já existia, os arquitetos simplesmente não a conseguiriam ouvir" ${ }^{177}$. O que restaria a se fazer se o espetáculo acabou, a cortina caiu e os atores já se revelaram pessoas comuns para aquém dos príncipes e reis que representaram?

Em "Teorias e história" Tafuri deixava claro a posição do crítico como um contestador: das iniciativas mais bem sucedidas, os projetos mais discursivos e seus resultados mais profundos deveriam ser alvo de meticulosa reflexão por parte do teórico. Neste sentido, a tarefa que o autor romano rogava para si, especialmente no que concernia o presente, era de ser o antagonista destes que se propunham a performar a tragédia universal, que só se alcança através da representação, na contemporaneidade. $\mathrm{Na}$ estrutura dramática, o antagonista é aquele que impele a trama à girar, aquele que dá sentido à ação do protagonista. "A história serve para desfazer a nostalgia, não para nos inspirá-la”, escreveu o autor na mesma entrevista. Diante de uma crise de senso histórico e interlocução, seria preciso uma força muito elaborada que provocasse os arquitetos a fazer o oposto de suas palavras. Por esta razão, toda sua recomendação direta aos arquitetos deve ser lida com cautela, porque é implícita na sua construção histórica a intenção de desbaratar os arquitetos. Menos do que esclarecimentos, ou colaboração no entendimento desta crise, Tafuri queria desarmá-los de vez, tornar inúteis as suas mais construtivas articulações. Ainda este aspecto teatral aparece como forte nos estudos de Tafuri: o do mis-en-scène. Tafuri exige de seu leitor uma astúcia, imediata contestação do conteúdo de suas recomendações; assim, a própria prosa do autor pelo seu caráter provocativo é

\footnotetext{
${ }^{176}$ SONTAG, Susan. "Under the sign of Saturn". Tradução para o português "Sob o signo de Saturno". In: Sob o signo de Saturno. Porto Alegre e São Paulo: L\&PM, 1986, p. 90. Grifo meu.

177 TAFURI, Manfredo. "Non c'è critica, solo storia", entrevista concedida a Richard Ingersoll. In: Casabella, n. 619-620, p. 98.
} 
movimento, devir entre os grandes arcos históricos e a conjuntura. A filologia e seu interesse e rigor pela precisão, como bem disse Tafuri à Cohen ${ }^{178}$, serve para que se teçam círculos cada vez mais próximos do tema que se estuda. Esta aproximação não era factual ou espiralar, mas realmente cíclica; a 'verdade' não aparece no corpo do texto. Como o Deus ex machina, esta reside em outro lugar, só se pode alcançá-lo passando pela instância dramática da performance de uma tragédia que redima a arquitetura.

${ }^{178}$ COHEN, Jean-Louis. "La coupure entre architectes et intellectuals". Op. cit. p. 217. 

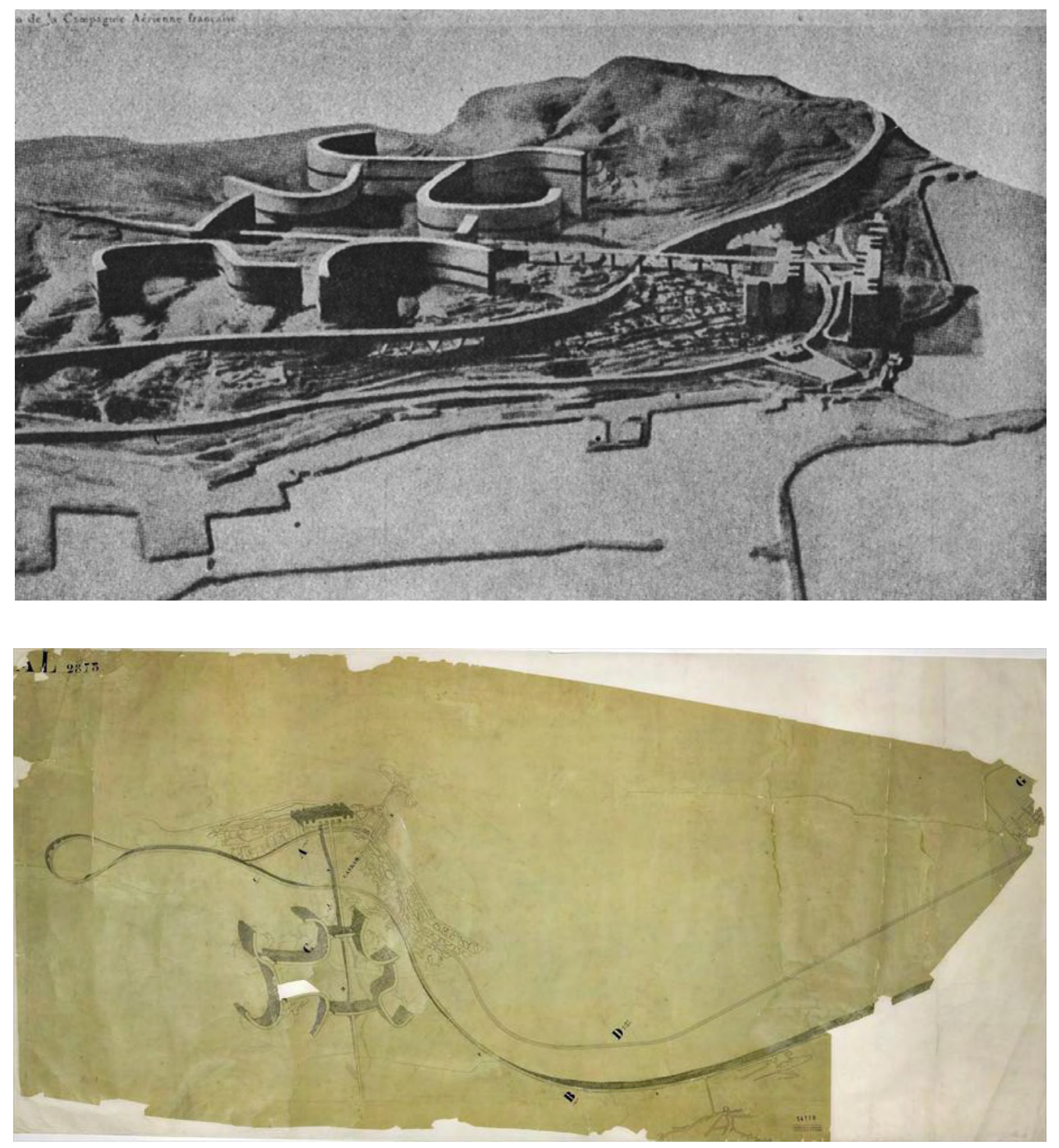

Le Corbusier, Plan Obus, Argel, 1933. 

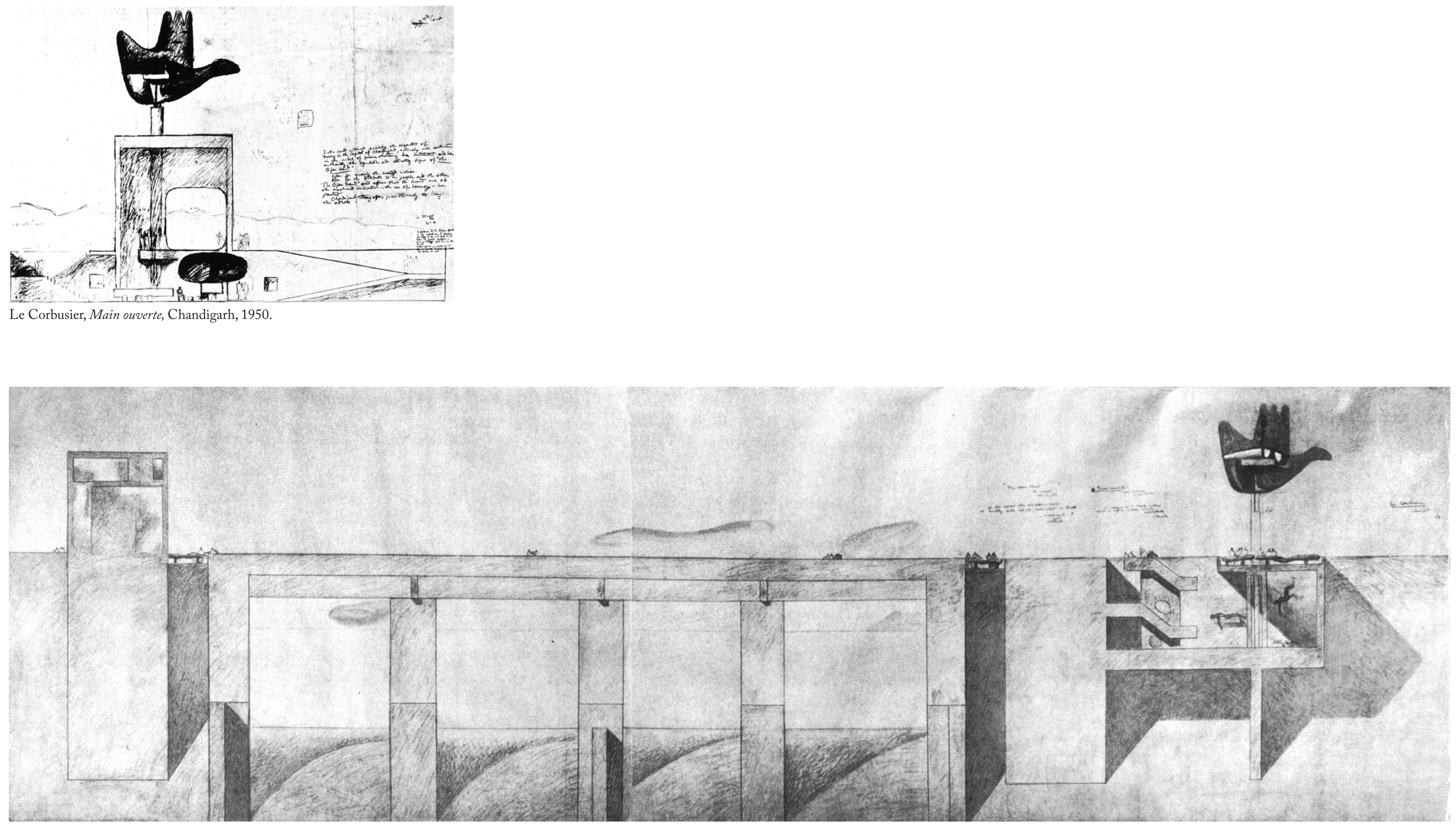

Le Corbusier, Main ouverte sobre a barragem de Bhakra, 1958. 


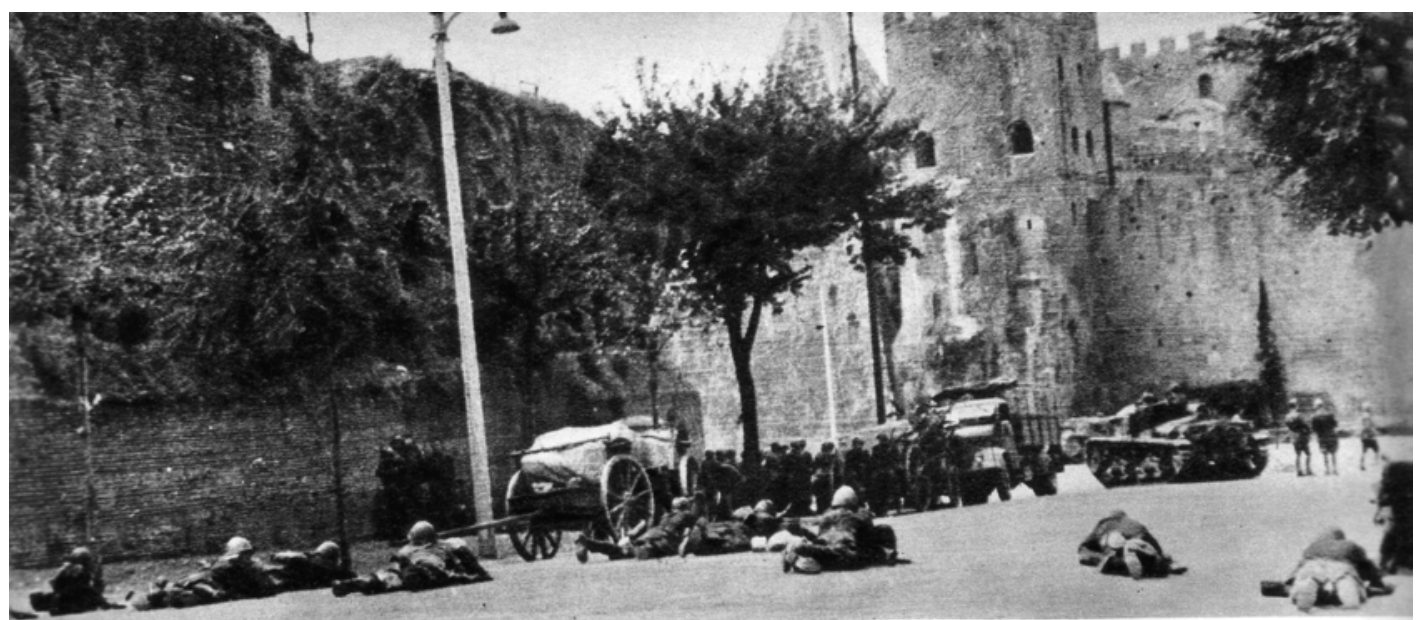

Batalha na Porta San Paolo, Roma, 1943.

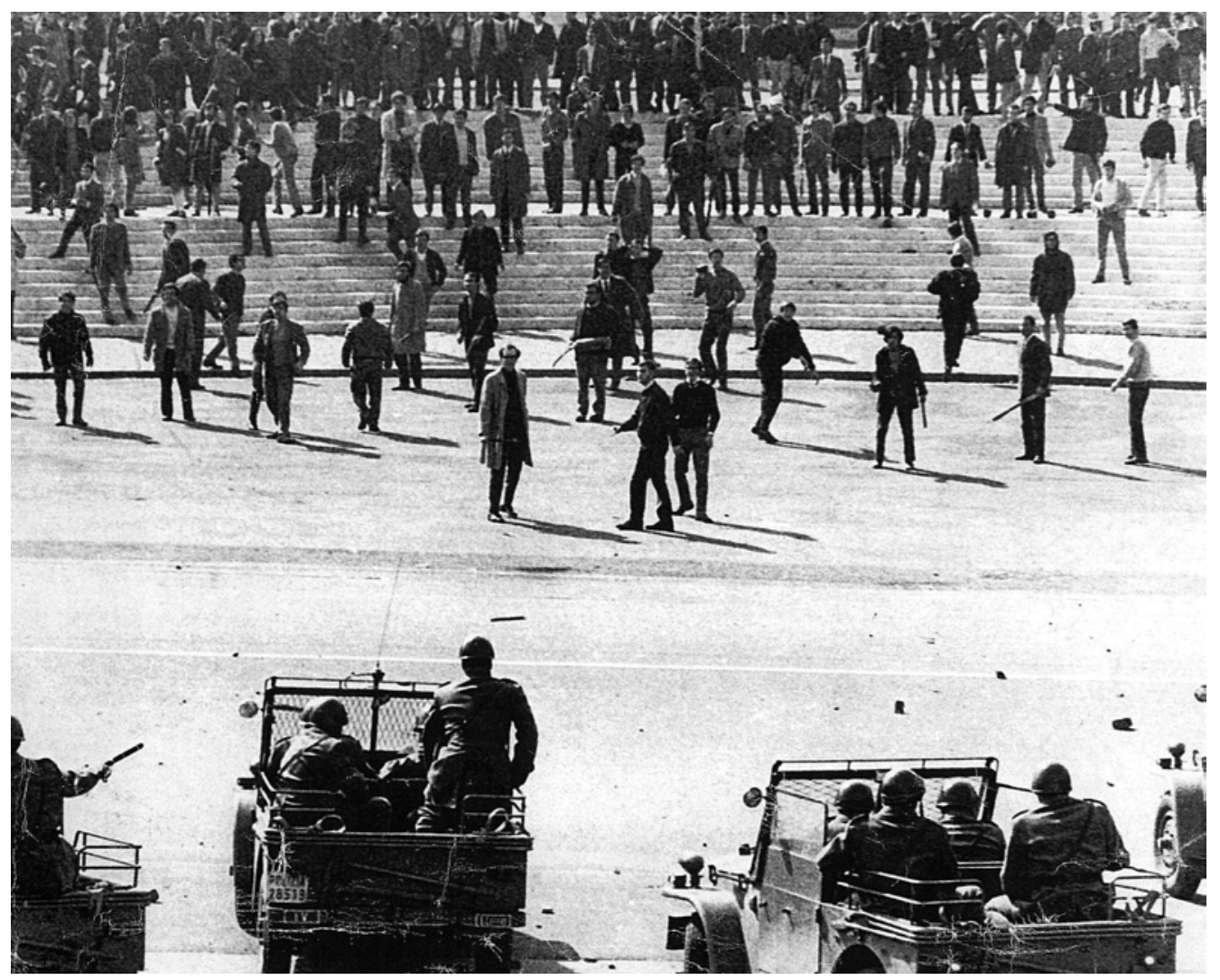

Ocupação estudantil na Faculdade Valle Giulia, Roma, 1968. 

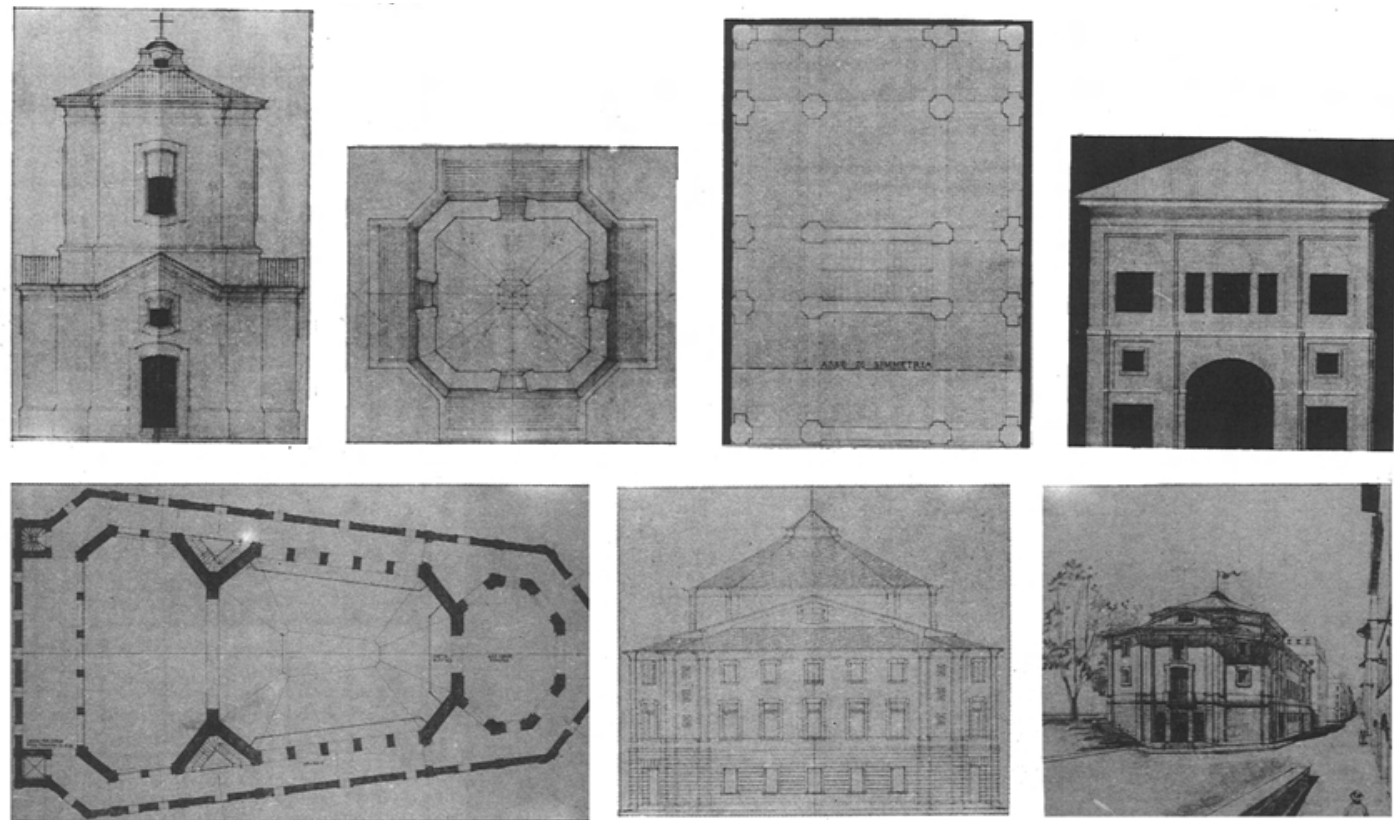

Exercícios de estudantes de Saverio Muratori, circa 1960.

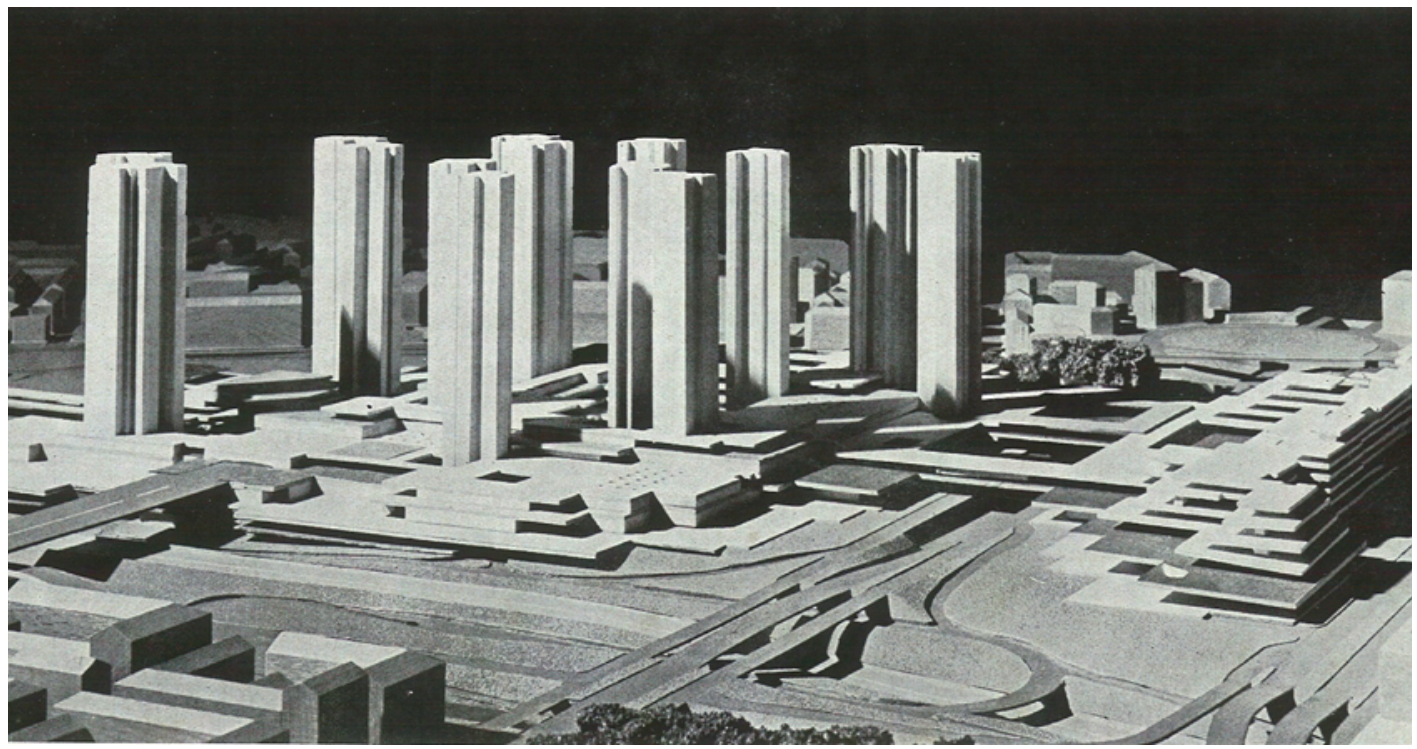

Ludovico Quaroni et. alt. Centro Direcional de Turim, Proposta vencedora, 1963. 

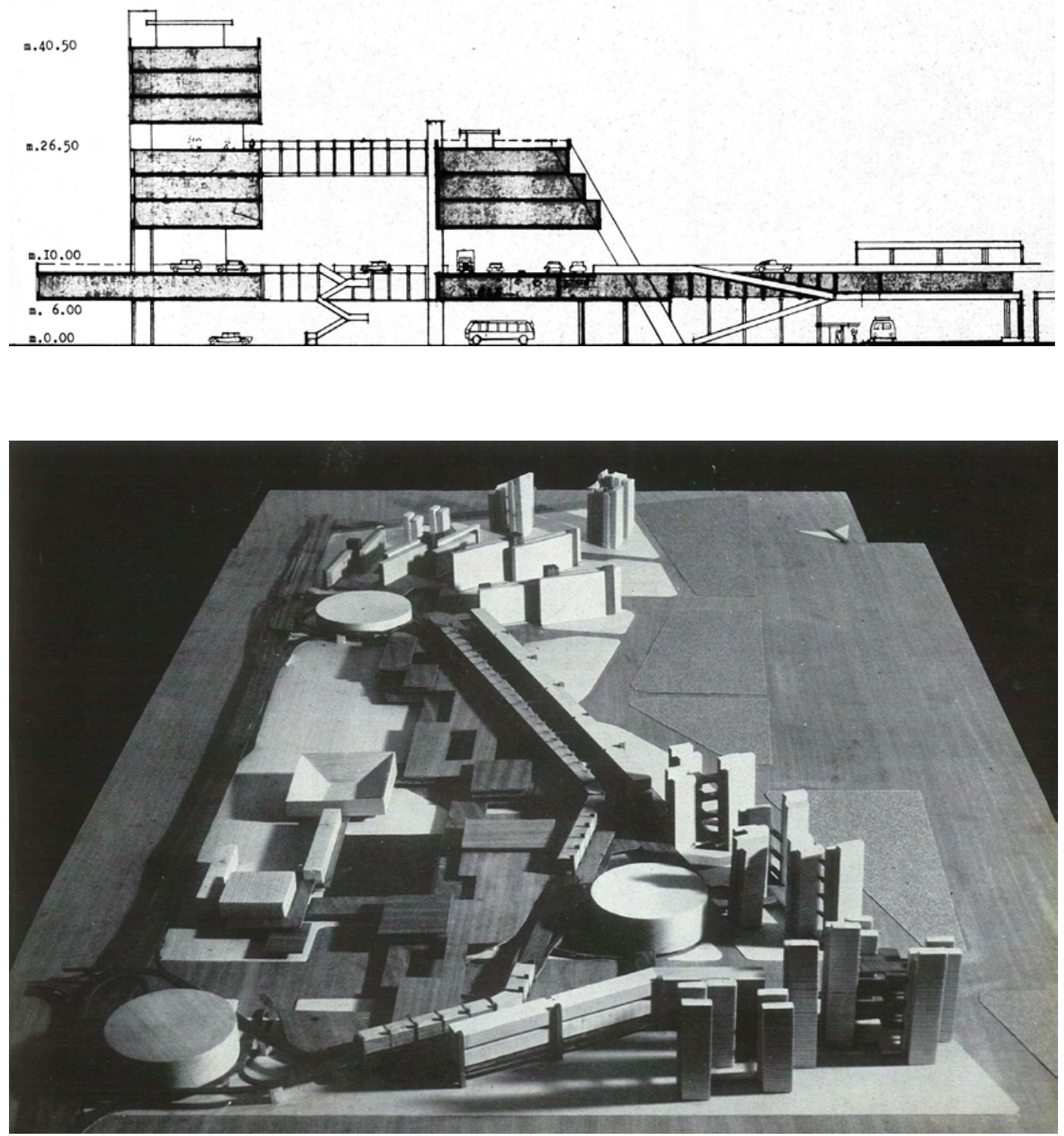

Studio AUA, Centro Direcional de Turim, Projeto destacado, 1963. 


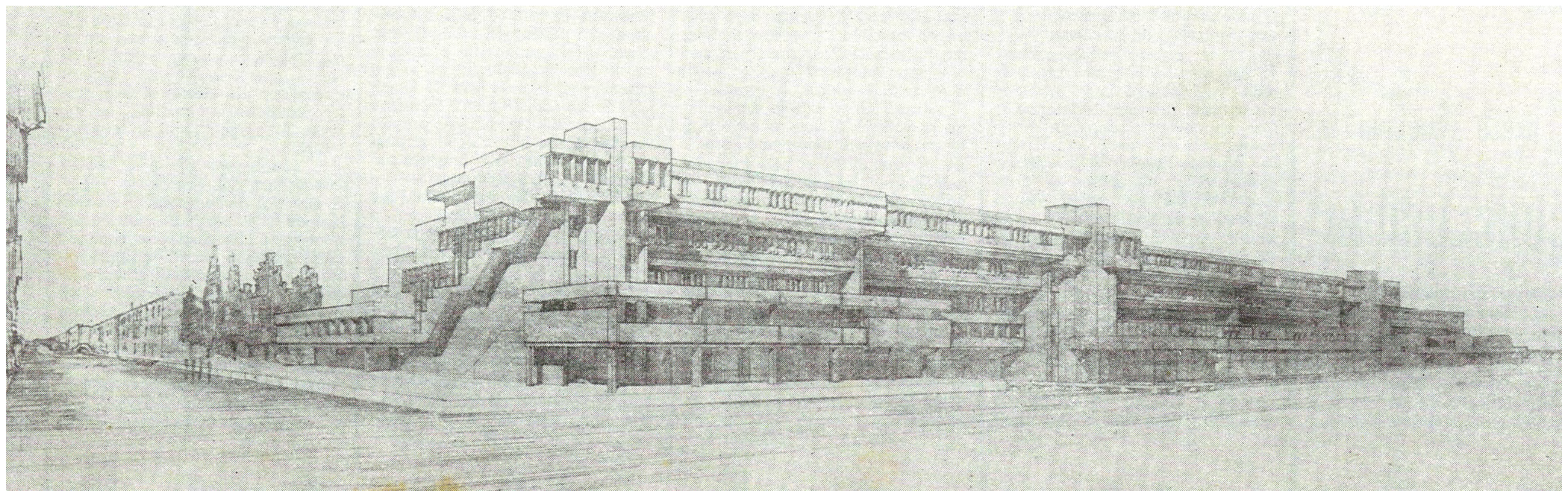

Studio AUA, Concurso para o Hospital de Veneza, 1964. 

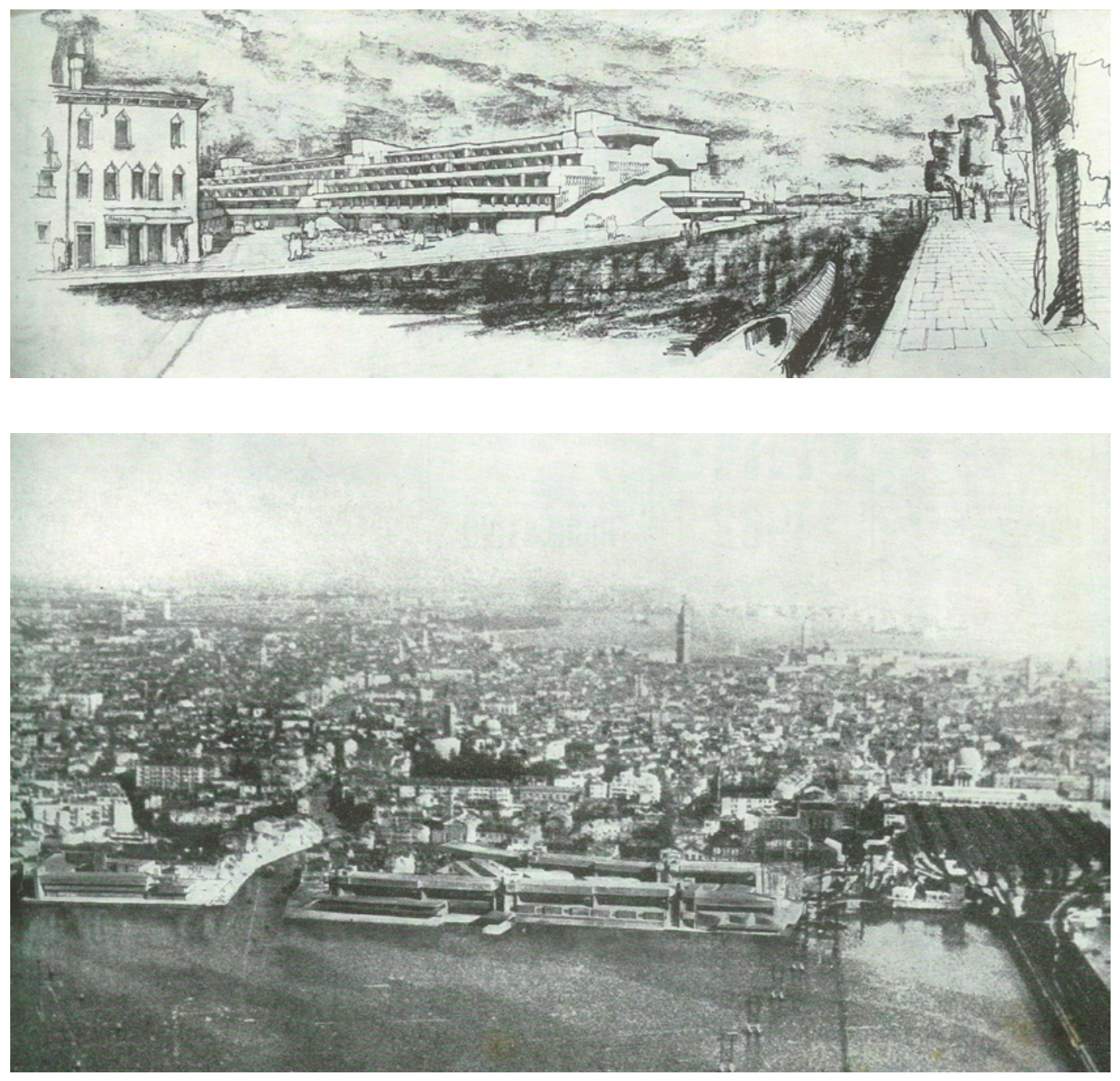

Studio AUA, Concurso para o Hospital de Veneza, 1964. 

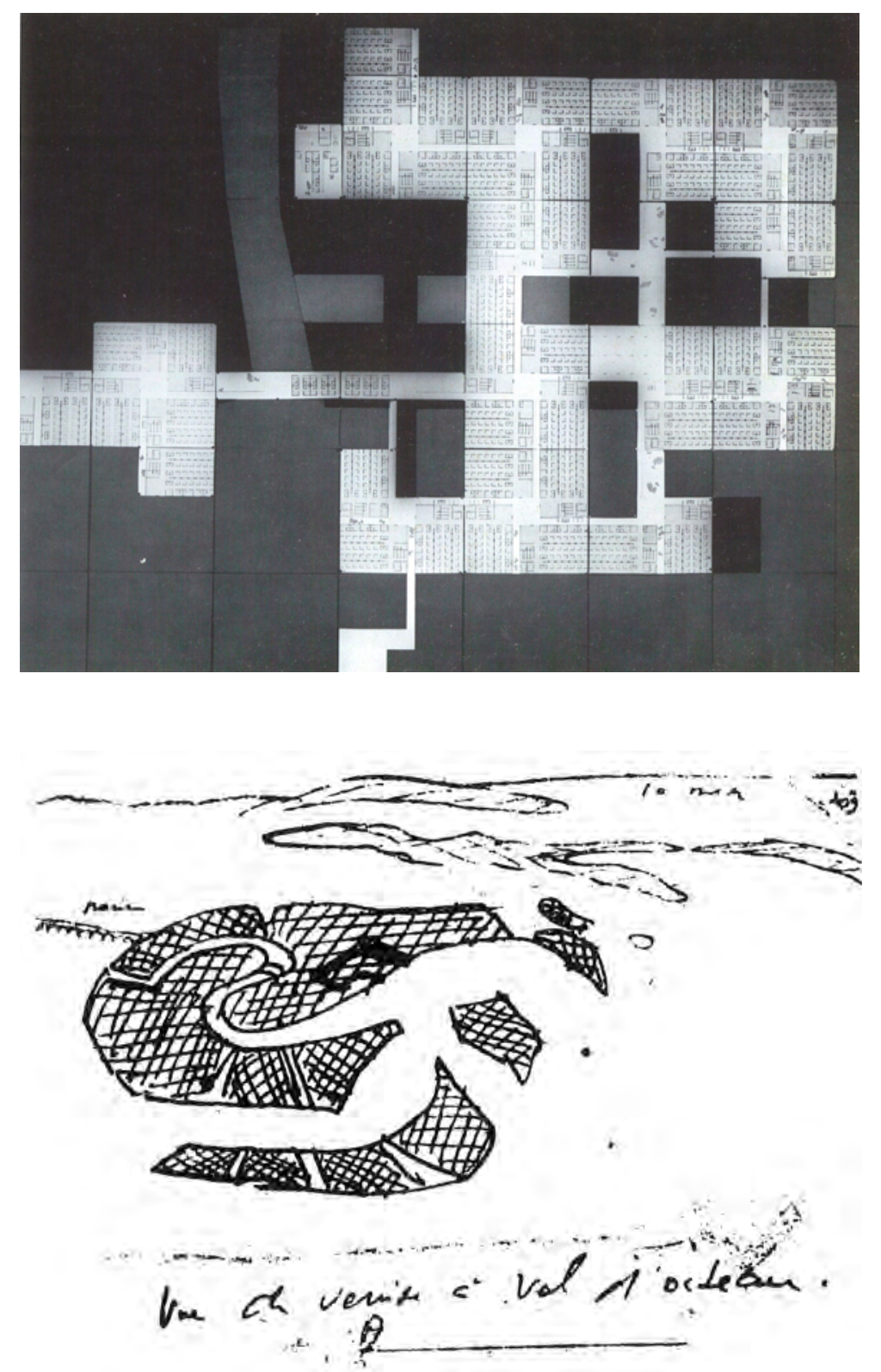

Le Corbusier, desenhos para o Hospital de Veneza, 1965. 

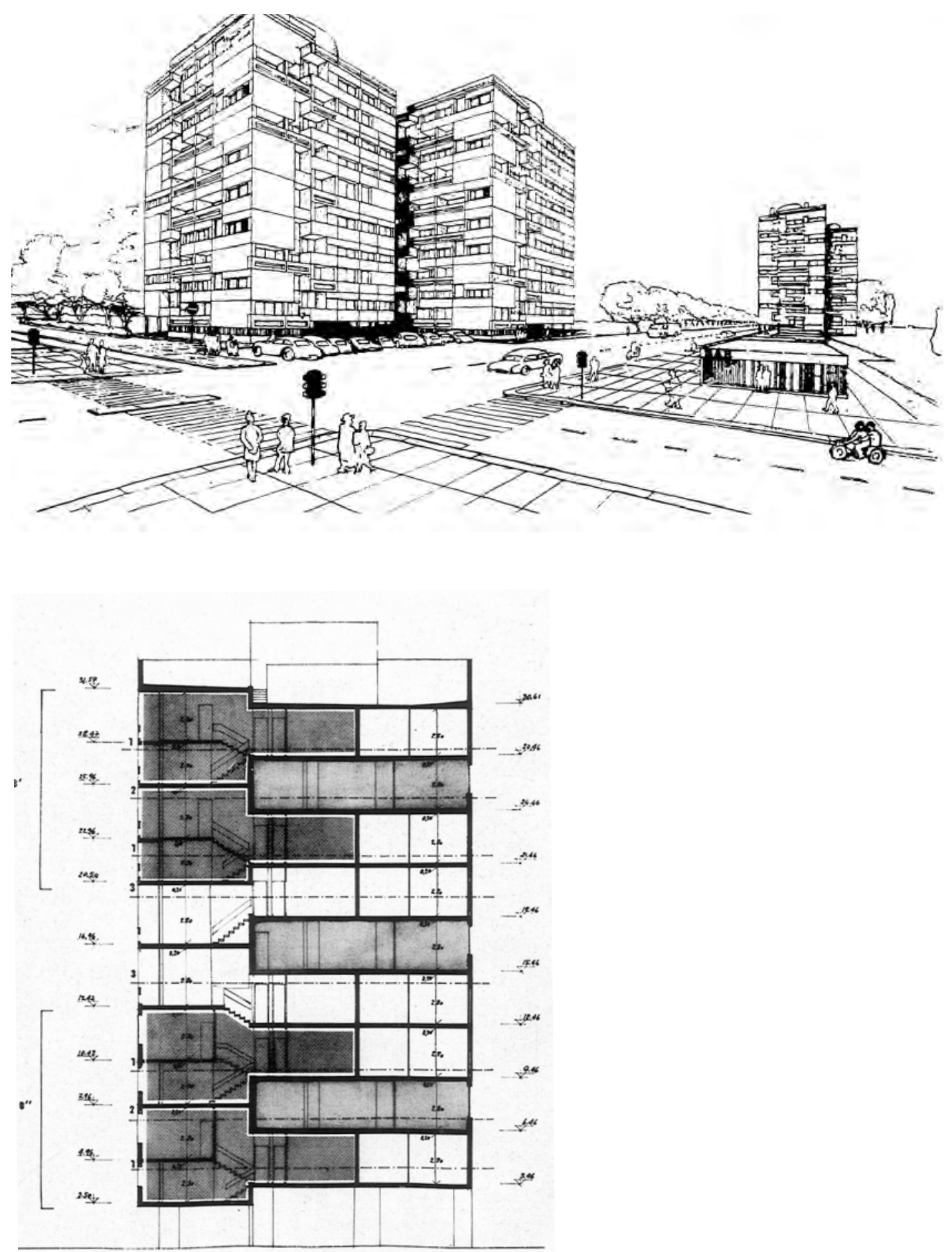

Studio AUA, Edifício habitacional em Latina, 1964. 

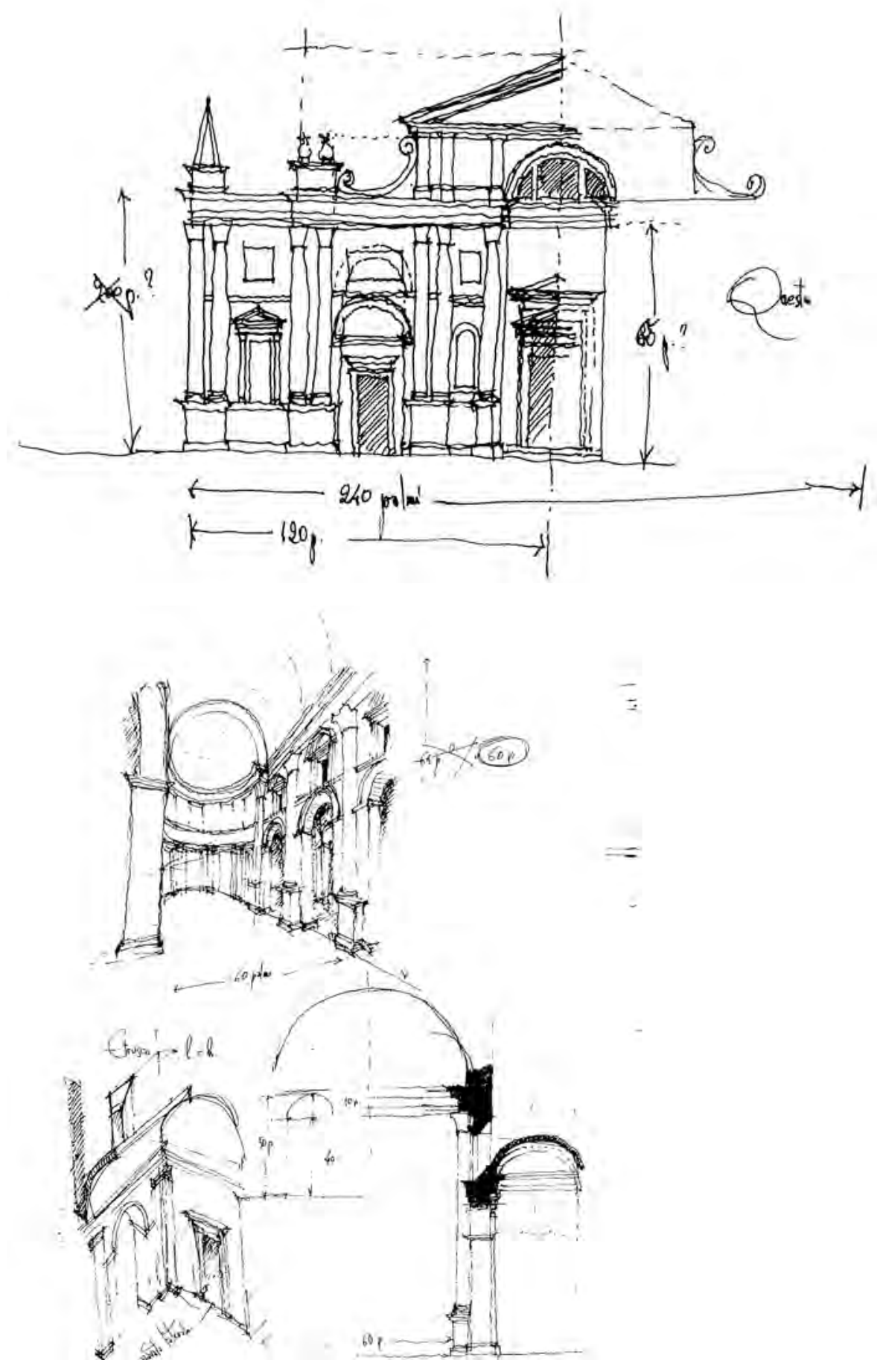

Manfredo Tafuri, Desenhos de estudo da Igreja de San Giovanni dei Fiorentini, proposta de Antonio Sangallo, o Jovem. 


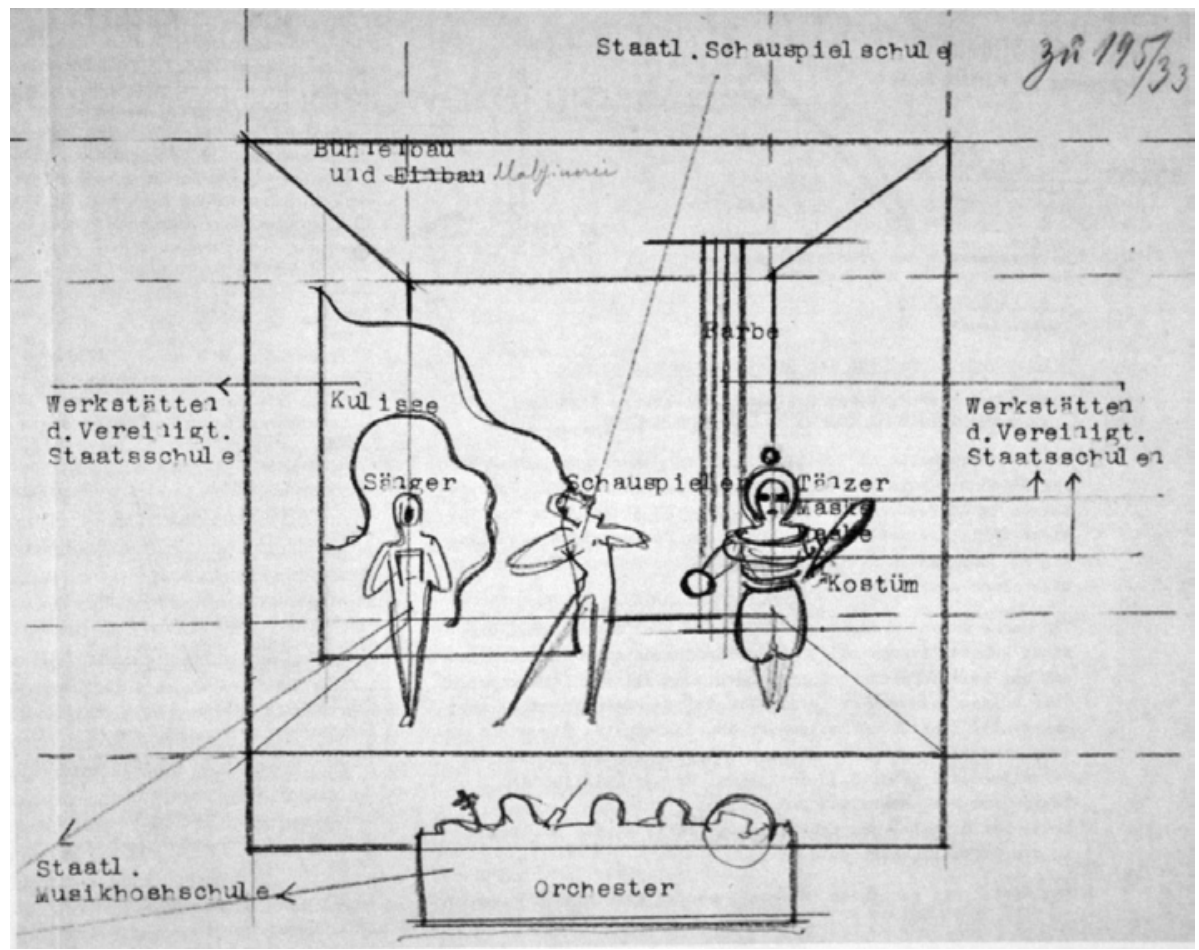

Oskar Schlemmer, Croqui para o Ballet Triádico, 1922.

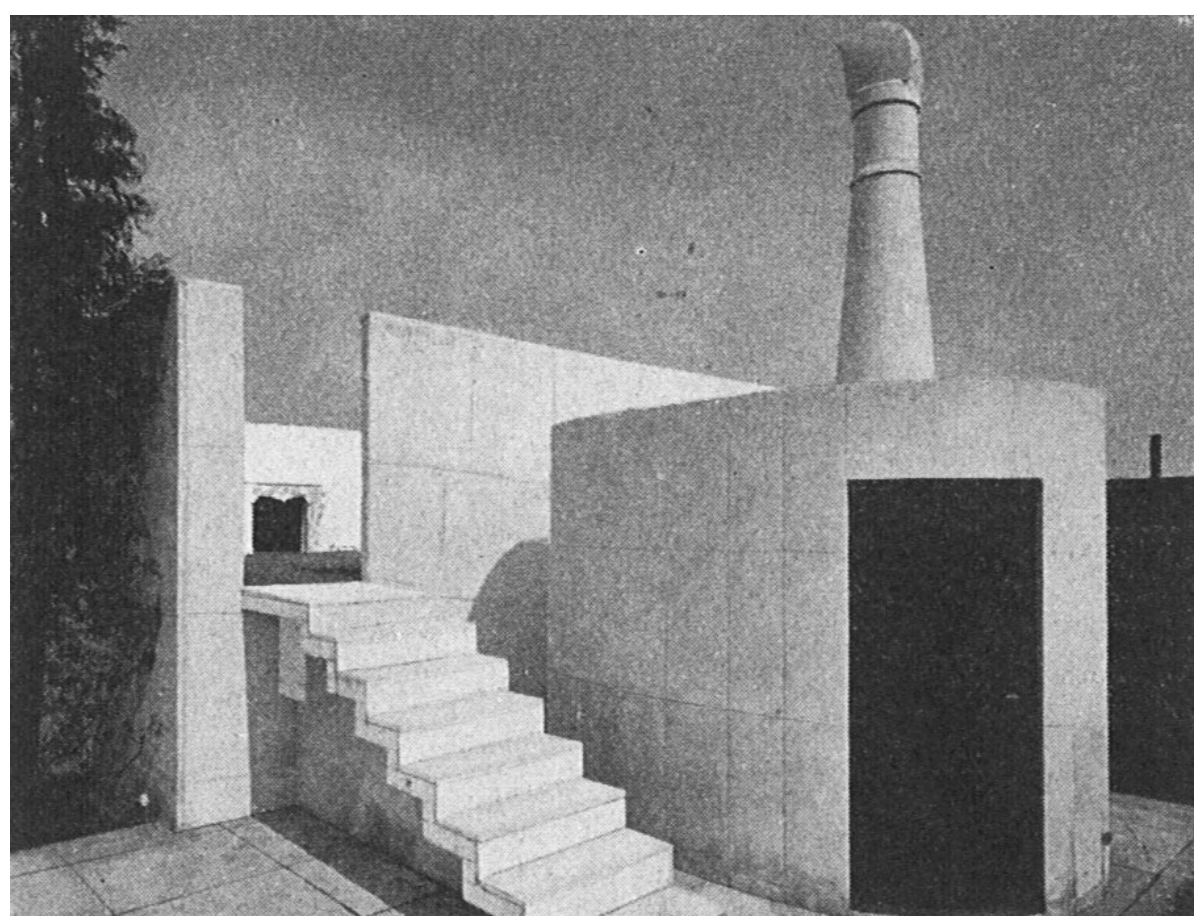

Le Corbusier, Cobertura De Beistegui, Paris, 1929. 


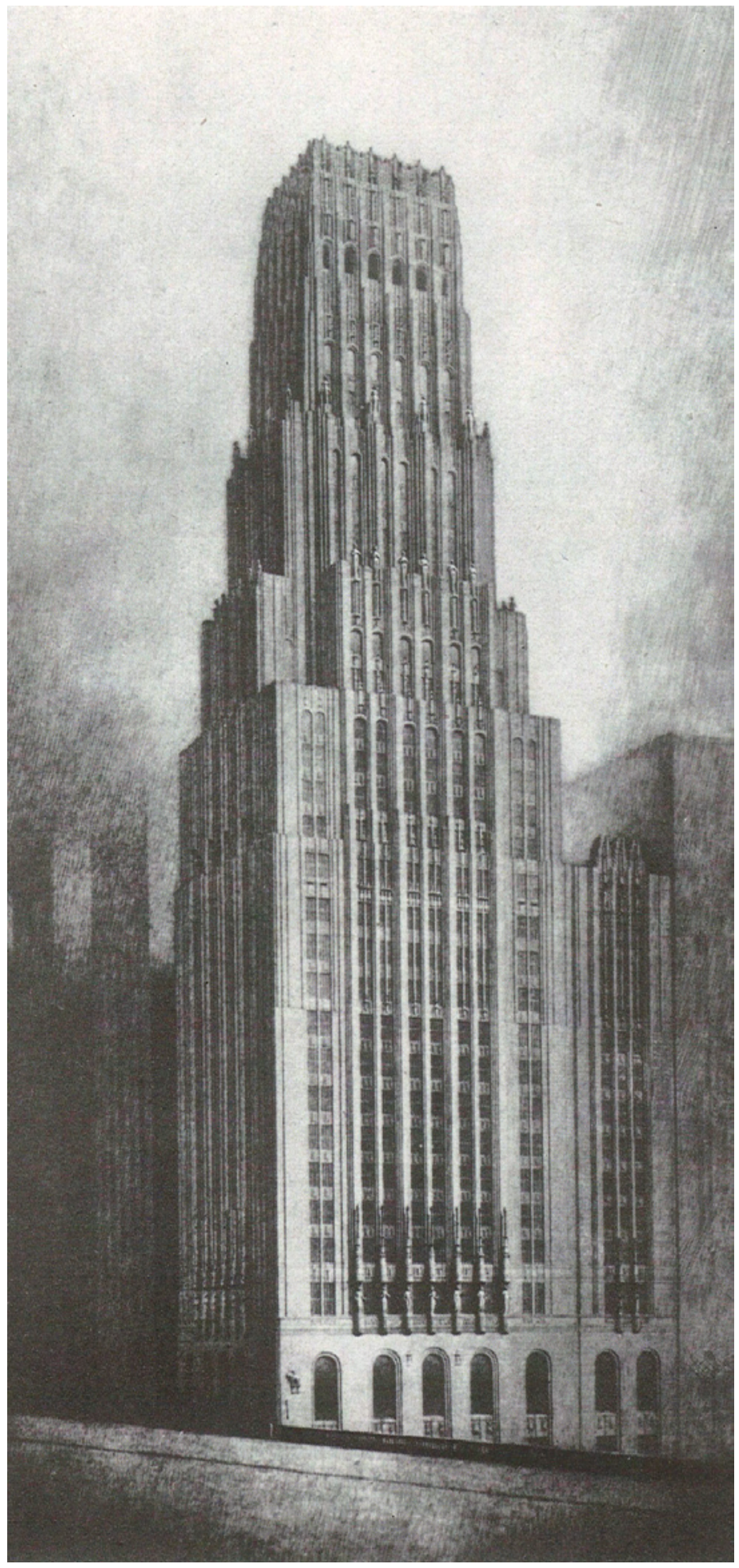

Eliel Saarinen, Concurso para Chicago Tribune Tower, Chicago, Segundo lugar, 1922. 


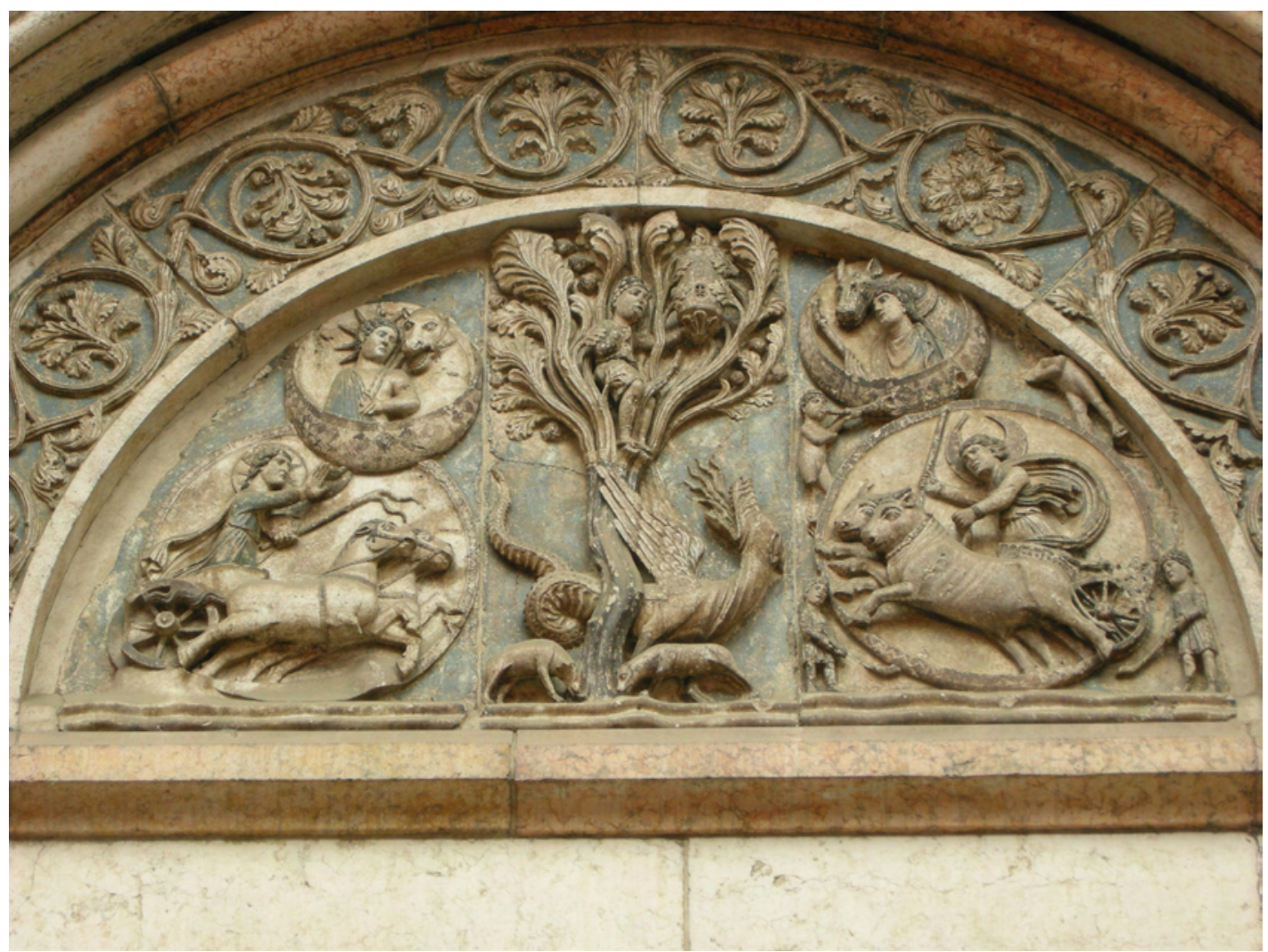

Benedetto Antelami, portal sul do Batistério de Parma, 1196.

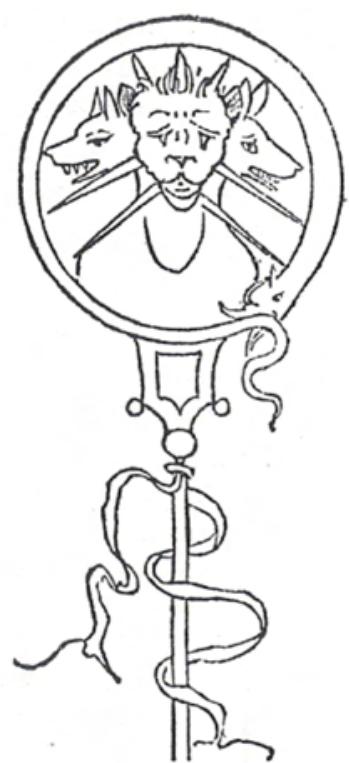

Ilustração do tricipitium em "Hypnerotomachia Poliphili", Francesco Colonna, 1499. 


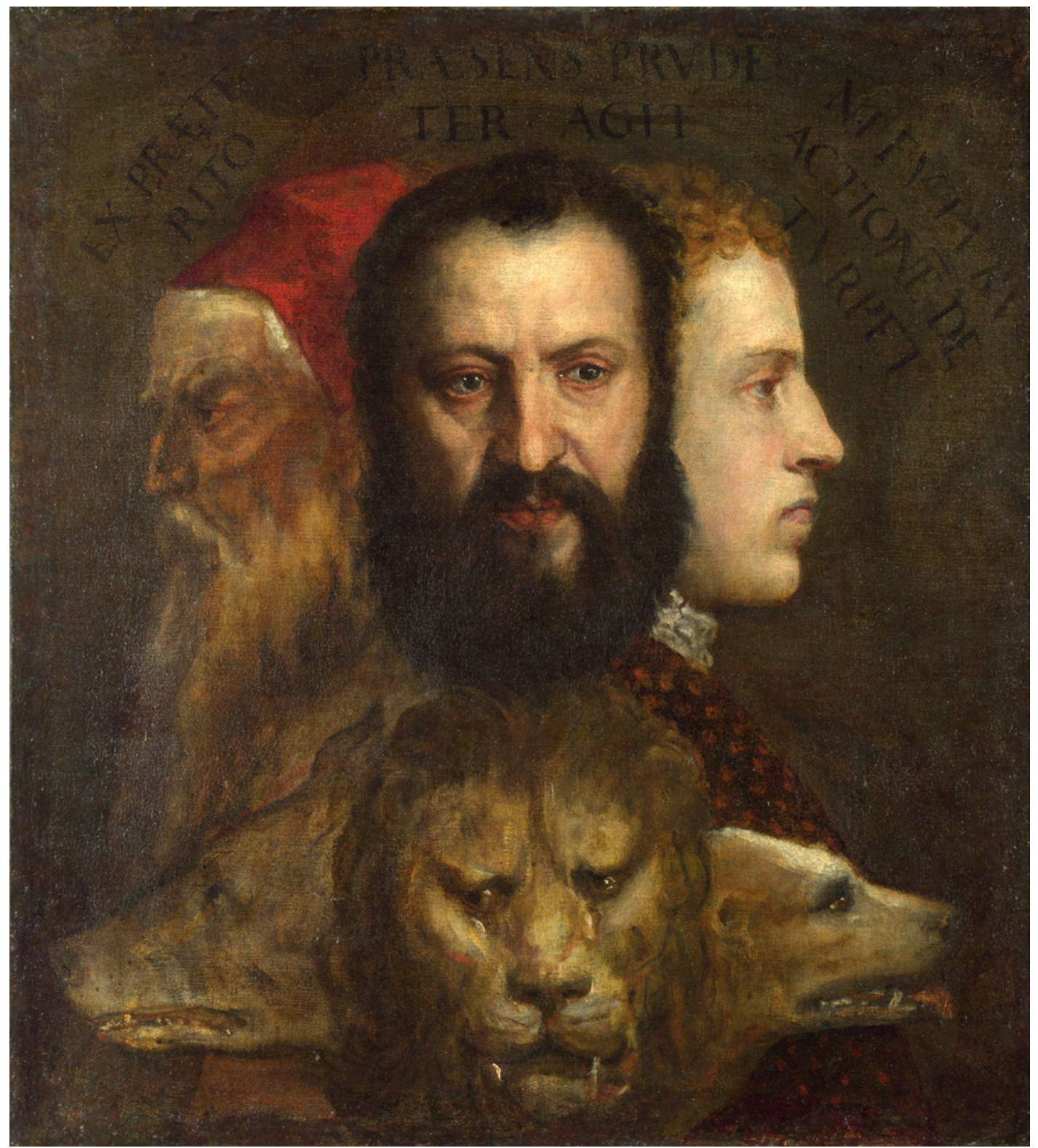

Giorgione, Allegoria della prudenza, 1570. 


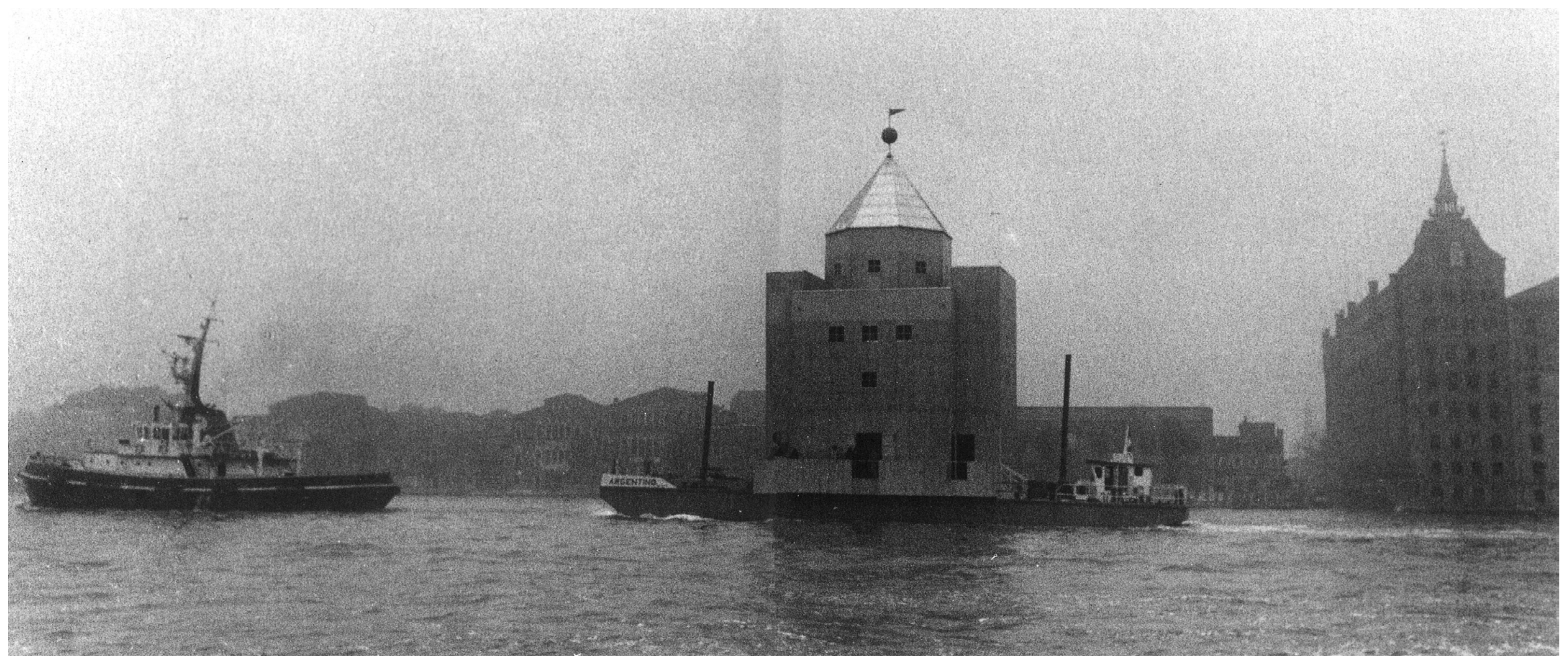

Aldo Rossi, Teatro del mondo, Veneza, 1979. 


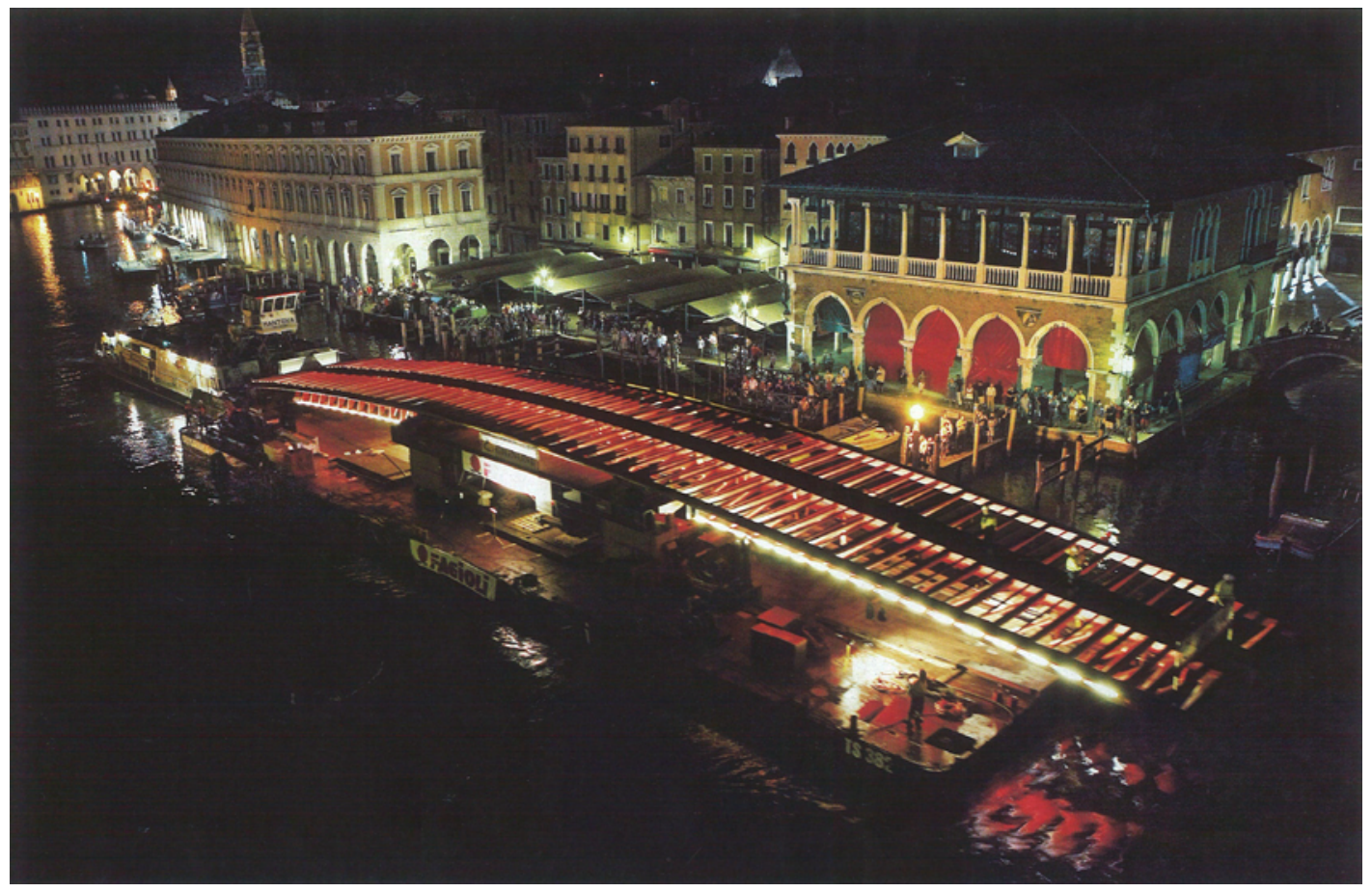

Santiago Calatrava, Quarta ponte sobre o Canal Grande, Veneza, 2008. 


\section{Cidades longínquas}

É conhecida a imagem feita pelo professor Howard Burns acerca de Tafuri em Vicenza, ao princípio dos anos oitenta, quando o autor romano subiu na ponte San Michele e disse: "A partir de agora, vou só pesquisar a boa arquitetura"179.

Usualmente esta anedota vem para reforçar a hipótese de que Tafuri, ao se afastar dos temas contemporâneos a partir de 1981, favoreceu os temas da arquitetura do humanismo pela sua maior complexidade e apuro, a "boa arquitetura". O depoimento feito por Burns fomentou certa polêmica, especialmente nas acusações de simplismo acerca deste tema complexo que é a mudança de fulcro nas pesquisas do historiador a partir dos anos oitenta.

Ao que poucos atentaram neste mini conto é na metáfora da ponte. Para reforçar o teor da declaração, Burns posiciona Tafuri sobre esta estrutura de entremeio; demonstra sensibilidade com a obra de seu colega, cujo trabalho de historiador foi pautado na busca pelo devir de dilemas consolidados na forma arquitetônica ao longo do tempo, para a qual a imagem evidentemente convence: um trabalho de contraposição, cotejamento, distanciamento e reaproximação de margens.

A ponte a qual refere-se Burns está ali para apontar a mais conhecida dialética de Tafuri: aquela entre a era da máquina e o humanismo. Isto se torna especialmente interessante quanto se tem em mente que a obra do autor romano não só apresentou uma ampla gama de períodos históricos, como também uma vasta ordem de movimentos e correntes ao redor do globo. São famosas as viagens de Tafuri para os Estados Unidos, sua crítica aos arranha-céus e ao modelo de crescimento adotado na América pelo New Deal. As suas incursões na Rússia e no Japão feitas no começo de sua carreira também renderam monografias importantes no quadro geral do autor.

${ }^{179}$ BURNS, Howard. "Tafuri and the Renaissance”. In: Casabella, n. 619-629, p. 117. 
Estas pesquisas poderiam ser vistas como comuns no trabalho de um historiador de arquitetura do século XX, afinal, foi o século em que de fato existiu uma ampliação dos focos de pesquisa para além dos centros europeus, sobretudo pelo caráter supranacional imanente das vanguardas artísticas. Via de regra, entretanto, a história da arquitetura moderna - mesmo aquela tecida por Zevi, Argan, Benévolo, entre outros autores mais velhos que Tafuri, foca-se na questão europeia das vanguardas, ao mesmo tempo em que dá crédito aos Estados Unidos etc.

As monografias sobre cidades distantes, culturas outras que não aquela eminentemente europeia na qual Tafuri tinha se formado, são obras nas quais o autor estava deslocado de seus temas originais. Os significados da forma, o peso da tradição e mesmo a sua construção de ciclos estruturais são colocados, nesses temas, em imediata crise. Do mesmo modo que o estudo do átimo em Tafuri precisa aprofundar como o autor resolveu a questão entre o humanismo e o contemporâneo, também esta dialética - esta ponte - entre urbanismo europeu e estrangeiro é parte da constituição de seu trabalho histórico.

A mais longa pesquisa feita por Tafuri sobre questões de fora da Europa Central tenha sido a do urbanismo nas duas grandes potências econômicas dos anos setenta e oitenta - União Soviética e Estados Unidos. Os interesses de Tafuri nestes dois países tinha uma óbvia natureza política, haja vista o confronto de modelos econômicos, a galopante diferenciação dos dois blocos pela cortina de ferro. $\mathrm{O}$ tema dos textos foca sobretudo nos modos como a arte e a arquitetura participaram da consolidação de duas vertentes antitéticas de organização social. Nestes trabalhos Tafuri está munido de uma grande estrutura de pesquisa. O seu Instituto de História de Arquitetura contava nos anos setenta com uma equipe notável que além de jovens historiadores, como Giorgio Ciucci, Jean-Louis Cohen e Marco De Michelis (entre outros), também tinha uma hierarquia bem definida de orientandos, muitos vindos dos países de origem das pesquisas, permitindo que o Instituto tivesse traduções próprias de documentos em russo ou dialetos. Era o período dos cursos de Tafuri focando amplas questões, como "A ideologia antiurbana" presente em algumas correntes pós vanguardas, ou mesmo semestres de estudos intensivos sobre a Rússia e Estados Unidos. 
Nesta divisão de trabalhos, os autores mais próximos de Tafuri assinaram monografias específicas sobre arquitetos ou temas, enquanto o autor romano ocupouse das visões de todo - que resultaria em um dos poucos volumes escritos à maneira de manual feito por Tafuri, "Arquitetura contemporânea”, assinado junto com Francesco Dal Co.

A dialética entre estas duas pautas de investigação só pode ser verdadeiramente analisada depois de ter em conta os resultados de pesquisa de cada uma delas.

A Rússia era particularmente discutida nos debates do período, afinal, tratavase da terra do socialismo realizado ${ }^{180}$. Malgrado nos anos setenta um ceticismo generalizado já tivesse recaído sobre as premissas libertárias da Revolução Soviética, ainda existia certo interesse - e algum romantismo - nas leituras das primeiras correntes de vanguardas surgidas na Rússia imediatamente após a Revolução. Tal movimento via-se claramente nas páginas da revista Casabella Continuità, nas palavras de seu editor Ernesto Nathan Rogers, que via nas correntes construtivistas e suprematistas uma "solicitação profunda nas zonas da arte", da qual "há ainda o que se aprender observando aqueles projetos" ${ }^{181}$.

Mesmo nas linhas da revista Contropiano, existia uma simpatia pela arte de vanguarda soviética e um certo apelo por uma recuperação de seus valores, como nas palavras de Francesco Dal Co, "O retorno portanto ao fecundíssimo período vivido pela arquitetura soviética pós revolucionária busca o alto escopo de reencontrar uma tradição perdida, que valha no operar presente, no momento em que todos os mitos da cultura arquitetônica vem demonstrando sua ineficácia prática”182.

Enfrentar a questão soviética, para Tafuri, era participar na ordem do dia dos debates italianos, e o viés da "crítica da ideologia" era oportuno para dar substrato a qualquer militância no campo. Com efeito, seus textos baseavam-se em pesquisas filológicas e depoimentos de alguns arquitetos que migraram para a União Soviética, como Ernst May. Em 1971 o Instituto preparou um volume quase exclusivamente amparado em fontes primárias de estudo - "Socialismo, cidade e arquitetura". O trabalho ladeava análises dos teóricos do Instituto com alguns depoimentos de

\footnotetext{
${ }^{180}$ QUILICI, Vieri. L'architettura del costruttivismo. Bari: Laterza, 1969, e, sobretudo, Casabella, n. 262, 1962.

${ }^{181}$ ROGERS, Ernesto Nathan. "Russia, contenuto e forma". In: Casabella, n. 262.

182 DAL CO, Francesco. "Architettura e piano in Unione Sovietica: stalinismo e il 'destino dell'avanguardia”. In: Contropiano. n. 3, 1969, p. 527. Grifo de Francesco Dal Co.
} 
arquitetos estrangeiros que foram para a Rússia no pós guerra, criando um debate entre pesquisadores e arquitetos. Ali tinha-se a clara intenção de coordenar interpretações comuns do grupo de Tafuri, criando um quadro geral de interpretações sobre o assunto em termos negativos, mostrando que também no socialismo realizado recaia uma crise imanente dos pressupostos das vanguardas, na sua pretensão de intervir na práxis. Não chega a ser uma surpresa esta exposição negativa feita pelo autor romano e seu grupo se termos em conta que três anos antes em "Teorias e história da arquitetura" construtivistas seminais como Ladovsky e Melnikov apareciam à contra luz dos arquitetos alemães e franceses na sua interpretação do alcance das vanguardas $^{183}$.

Como o próprio Tafuri atestava na introdução do volume, o conjunto de artigos visava "contribuir e especificar, em um delimitado campo de disciplinas, as razões políticas que determinaram as mistificações do socialismo realizado, a identificação do Socialismo com Plan, o nascimento e consolidação da ideologia do Proletariado como novo sujeito histórico, como nova Totalidade que leva a cabo o destino de 'libertação' universal através da libertação do trabalho.”184

Segundo Tafuri, todas as vanguardas, independente de estarem no ocidente ${ }^{185}$ ou na União Soviética, se reencontram no tema do trabalho e das indagações acerca de sua libertação. Malgrado o construtivismo russo crescesse durante a Revolução de Outubro livre das apontadas contradições do capitalismo industrial, Moscou socialista era pensada nos moldes racionalistas cujo atrelamento à razão era similar àquele perpetrado do outro lado da cortina.

É conhecida e trabalhada já à exaustão a noção de ideologia do plano construída por Tafuri em "Por uma crítica da ideologia arquitetônica". Nela temos que a utopia tem um papel visceral na inteligência das vanguardas artísticas, de modo mais sofisticado do que uma simples projeção de um futuro organizado. Com uma dialética

\footnotetext{
${ }^{183}$ Como já vimos anteriormente em TAFURI, Manfredo. Teorie e storia dell'architettura, Op. cit. p. 61. ${ }^{184}$ TAFURI, Manfredo. "Nota preliminar". In: ASOR ROSA et alli. Socialismo, città e architettura. URSS 1917-1937. Il contributo degli architetti europei. Tradução para o espanhol Socialismo, ciudad y arquitectura. URSS 1917-1937. La aportación de los Arquitectos Europeos. Madrid: Alberto Corazón, 1973, p. 13. Grifo de Tafuri.

${ }^{185}$ Utiliza-se a oposição entre a União Soviética ao Ocidente porque assim aparecia nos debates italianos do período, desde a Revista Casabella até em publicações do debate. O contraste que se colocava já ficava evidente nesta terminologia, que identificava a Europa do lado capitalista como ocidente, detentora portanto de toda a história social tradicional. A União Soviética, tendo começo em um país de dois continentes como a Rússia, aparecia como outra a esta tradição.
} 
entre correntes ditas construtivas e destrutivas, as vanguardas constroem um discurso interdependente que ao mesmo tempo em que reconhece a miríade de contradições perceptivas (e de vida concreta) dentro dos grandes centros, ao mesmo tempo delas se nutre para desenhar um devir à organização completa e otimizada destes estímulos. $\mathrm{O}$ resultado é conhecido: arte como modelo de ação, proposta de conciliação perceptiva entre habitantes da metrópole e as mais urgentes necessidades de dinamização do trabalho dentro da organização capitalista industrial. "À ideologia arquitetônica, artística e urbana resta a utopia da forma, como projeto de recuperação da totalidade humana numa síntese ideal, como posse da desordem através da ordem.”186 A partir desta ideologia de uma reorganização global que começa pela completa absorção das contradições da metrópole reside toda a crítica do autor romano feita à arquitetura moderna na década de sessenta e primeiros anos da década de setenta.

Este discurso, legado de um período em que a matriz filosófica de Tafuri era amplamente informada por Massimo Cacciari e suas deambulações sobre temas como a cidade contemporânea e a dialética do negativo na metrópole ${ }^{187}$.

Tafuri enfrenta a questão do trabalho e do trabalho intelectual em uma seção de "Por uma crítica...", mas de modo muito panorâmico, deixando para seus colegas esta tarefa, como Alberto Asor Rosa em "Trabalho intelectual e utopia da vanguarda no país do socialismo realizado”. De todo modo, na União Soviética tem-se menos a presença das ditas 'vanguardas negativas', mas é certo que o tema do trabalho está em toda a parte. O produtivismo e o construtivismo, os manifestos de Rodcencko e Stepanova que pregavam que a arte do presente e a vida construtiva são modos de expressar uma planificação às necessidades do trabalho. Ainda que dentro de um regime revolucionário, a Rússia tinha a difícil tarefa de resolver um déficit produtivo deixado pelo czarismo, exigindo uma grande investida econômica que demandava uma rápida industrialização. Neste sentido, as suas cidades mais constituídas virariam palco de uma otimização similar às do ocidente. Se no mundo capitalista trabalho intelectual e manual não se conciliam, nas propostas de planificação dos construtivistas ele pôde ser de fato uma realidade. O mérito das vanguardas russas era criar um arcabouço geral onde a tarefa do intelectual poderia estar completamente alinhada ao trabalho

\footnotetext{
${ }^{186}$ TAFURI, Manfredo. "Per una critica dell'ideologia architettonica", Op. cit. p. 38.

${ }^{187}$ CACCIARI, Massimo. Metropolis, Op. cit. Do mesmo autor, neste mesmo tema: "Sulla genese del pensiero negativo". In: Contropiano. n. 1, 1969.
} 
operário, produtivo. Não à toa, muitas das mais radicais propostas das vanguardas ocidentais bebiam desta fonte primeira do socialismo realizado, especialmente as ditas 'correntes positivas'.

O processo todo é análogo ao desempenhado dentro dos centros capitalistas ocidentais. Entre a Europa Ocidental e a União Soviética, portanto, não existem diferenças viscerais pelo fato da segunda ser palco do socialismo realizado. É sobretudo na consolidação da "Nova Política Econômica" - o NEP - que se atrela na terra do socialismo realizado o crescimento econômico a uma divisão de trabalho. A partir daí, segundo Tafuri, todo o conteúdo libertário das vanguardas soviéticas perde sua força de contraste em relação ao ocidente. "A extinção do trabalho", escreveu Tafuri, "o fim da alienação trabalhadora, a restauração do conceito de Totalidade humana, só podem ser realizadas como imagens." ${ }^{188}$ Os clubes operários dos irmãos Vesnin, o desurbanismo de Ginzburg, todos se tornam propaganda de uma liberdade que não tem lugar nas fábricas.

O clube operário será o lugar onde tal relação [homemmáquina] deverá se carregar de significados. É precisamente a distância da fábrica do clube operário que permite tal recuperação; portanto, o alheamento semântico influirá sobre as imagens da cadeia de produção, abstraído até assumir as características de um conjunto de puros signos geométricos. Aqui começará o trabalho do técnico da forma: sua tarefa será não de fazer significantes estes sinais, mas fazê-los 'chocarem-se' entre si, assumir seu vazio como material de uma comunicação intencionalmente ambigua, já que se encontra suspensa entre a pura hermética afirmação de si mesma e a indicação - igualmente hermética - de uma forma como tendência a um inatual princípio de Razão. ${ }^{189}$

\footnotetext{
188 TAFURI, Manfredo. "Il socialismo realizzato e la crisi delle avanguardie". In: Socialismo, città e architettura. Op. cit. p. 79.

${ }^{189}$ Idem, p. 83. Grifos de Tafuri.
} 
Esta interpretação de Tafuri acerca da dialética entre clubes operários e fábricas é quase uma paródia da comparação feita por Walter Benjamin acerca do trabalho operário e as apostas nos cassinos. Uma condiciona, no tempo livre, a outra a aceitar o vazio existente no labor operário. A diferença é que enquanto Benjamin via uma relação comportamental de jogos de apostas, Tafuri procura ver um condicionamento na esfera da visualidade. O jogo geométrico e decomposições de linhas e planos procuram dar, pela exaustão do procedimento sintático, o esvaziamento dos significados da revolução, no que concerne o trabalho. Esta interpretação de esvaziamento pela sintaxe vai ser particularmente retomado quando o autor romano voltar os seus estudos para a questão americana, mais ligados à correntes particulares dos anos setenta.

É certo que a distinção entre intelectuais e produção, cisão que no limite era justamente aquela que separava nos textos de Tafuri pré Veneza os arquitetos dos críticos, a alavanca que dava todo o sentido para que o jovem autor romano abrisse mão de sua prática escritorial em prol de uma vida pautada pelas palavras, era uma condição particular do cenário capitalista. Se Tafuri estivesse na União Soviética um livro como Teorias e bistória da arquitetura não precisaria ser escrito. $\mathrm{Na}$ conclusão deste seu volume, ao falar que na história não existem soluções, o autor coloca que a única via possível é a "acentuação das contradições". Justifica esta postura ao colocar a "hipótese de uma mutação radical que nos faça considerar superadas a angustiante situação presente, bem como as tarefas provisórias que com esta obra tentamos clarificar para nós mesmos." 190

A perspectiva da revolução, apesar de distante no cenário europeu do final dos anos sessenta, não era completamente fantasioso. O encerramento deste livro praticamente inaugura o primeiro ciclo de Tafuri dentro do Instituto em Veneza aquele ciclo de coesão quase total entre seus textos com os de Cacciari e Dal Co, da articulação firme de todos os professores com temas preestabelecidos e alinhados com o engajamento político. Ademais, a Itália do final dos anos sessenta era cenário de uma ampla mobilização política, haja visto as revoltas anti fascistas no sul da península e sobretudo as revoltas estudantis de 1968, que no país foram tão intensas quanto na França. “A partir de 1967, vários grupos locais começaram a aparecer”, dizia o escritor

${ }^{190}$ TAFURI, Manfredo. Teorie e storia dell'architettura, Op. cit. p. 291. 
americano Jim Kaplan, em seu apaixonado ensaio sobre a "nova esquerda" italiana. "Estes grupos locais tornaram-se tanto colhedores como catalisadores de maiores movimentos. Do surgimento do movimento estudantil em 1968, a explosão das classe trabalhadora industrial no quente outono de 1969, a insurreição cidade após cidade no sul e o princípio de um movimento feminino, o capitalismo italiano foi ameaçado por fortes, violentos e universais mudanças." ${ }^{191}$

Tafuri foi filiado ao partido socialista italiano, o PSI, durante os primeiros anos da década de sessenta, quando sua atuação como arquiteto alimentava muito de seu vigor teórico. Entretanto, sua filiação não durou até o final da década de sessenta, e sua associação com intelectuais ultrapassava partidarismos. De modo genérico, pode-se dizer que a Revista Contropiano, publicação que abrigou os textos mais radicais de Tafuri, é um desdobramento indireto da revista da famosa Quaderni Rossi. Todas possuíam uma pauta radical, que davam lastro e medida, no campo acadêmico, aos fermentos ocorridos nas greves e sublevações estudantis ${ }^{192}$.

A Contropiano tinha uma vontade de congregar diferentes conhecimentos para uma pauta comum. Ao completar um ano, a revista publica um "Primeiro Balanço", onde a causa operária é colocada no centro dos interesses desta revista acadêmica, e clama sobretudo à pesquisa teórica por uma unidade, um dever de aproximação, homogeneização e fusão ${ }^{193}$.

À este apelo feito pelos editores da revista - ao qual certamente fletiu-se a prosa de Tafuri, soma-se certa crença na iminência da modificação. Segundo De Michelis, o grupo possuía no período certa crença escatológica ${ }^{194}$ de que a revolução poderia mesmo ser disparada em breve, o que colocava o trabalho intelectual em uma posição de luta, também contra o universo da produção. Assim, a posição crítica vinha realmente do fim de uma aliança entre vanguarda e intelectuais - o que advém da

\footnotetext{
${ }^{191}$ KAPLAN, Jim. "Introduction to the revolutionary left in Italy". In: Radical America. n. 07, 1972, publicado no site "http://libcom.org/library/introduction-revolutionary-left-italy-jim-kaplan", acesso em 29/11/2012, 08:32.

${ }^{192}$ Cf. SPINI, Aldo. "The new left in Italy". In: Journal of contemporary history. v. 7, n. 1/2, 1972, pp. 51-71.

193 "Observando os movimentos da classe [operária], e não em nós mesmos ou em nossa inata predisposição a formar grupos, podemos individuar linhas de comportamento válidas; e neste momento é a luta de classe a sugerir-nos que não há iniciativa que funcione sem uma basilar preocupação com a unidade, sem o esforço de dar mesmo à pesquisa teórica um dever de aproximação, homogeneização e fusão." "Primo Bilancio". Op. cit., p. 240, grifo dos editores.

${ }^{194}$ Depoimento de Marco de Michelis ao autor em 27 de outubro de 2010.
} 
situação amplamente estudada por Tafuri em "Por uma crítica", um diagnóstico sistematizado acerca da contínua perda de espaço dos arquitetos de prancheta das possibilidades reais de colaborar com uma ressignificação da forma para uma revolução.

É redundar com a literatura já publicada sobre o tema trazer os meandros desta falência. No caso da União Soviética, ela serve como uma realidade especular, um fracasso dos arquitetos pós-revolução pelas mesmas razões de seus colegas prérevolução no ocidente. Após o plano quinquenal e a escalada do stalinismo, as censuras que recaem sobre os arquitetos do outro lado tornam completamente desinteressantes as análises do socialismo construído, sendo que a ele Tafuri não dedicará tantas linhas, nem direcionará o seu Instituto para o aprofundamento de sua falência - vista em linhas gerais como similares demais às do ocidente.

No outro lado da moeda tem-se o historiador como o único que pelo seu exercício pode formular uma crítica à arquitetura do presente. A análise do clube operário, do estudo da comunicação muda que ali se perfila aparece igualmente no ocidente, como vimos nas conclusões do autor presentes em "Por uma crítica". Este silêncio aparece de modo excelente nos Estados Unidos da América e na força de sua organização do território. "É necessário reconhecer, mesmo no setor das técnicas de planificação, os novos fenômenos e as novas forças protagonistas". ${ }^{195} \mathrm{Na}$ finalização de seu panorama sobre arquitetura e desenvolvimento do capitalismo, Tafuri toma um tom menos analítico e se volta para uma ampla crítica aos arquitetos dos anos sessenta em suas tentativas de recuperar as postulações modernistas em um período no qual o capitalismo está de tal modo consolidado que o "papel ideológico da arquitetura é mínimo".

Estas linhas do "Por uma crítica..." ficaram famosas e delas ficou a imagem de Tafuri como um grande autor negativo às possibilidades de retomada da posição do arquiteto no desenho das metrópoles dos anos sessenta. Passado o calor daqueles anos, mantem-se claro que a conclusão de "Por uma crítica" terminou em um fim de linha para os arquitetos. Entretanto, aqui existe uma diferença entre o artigo de Tafuri Por uma crítica da ideologia arquitetônica" e o livro revisado e publicado depois "Projeto e

${ }^{195}$ TAFURI, Manfredo. "Per una critica dellideologia architettonica". Op. cit. p. 116. 
utopia”. O último parágrafo foi modificado, revelando uma sutil mudança de fulcro nos textos do autor.

Em "Por uma crítica", o final do texto é análogo ao de "Teorias e história": Tafuri entrega à contingência política o resultado de suas considerações:

$$
\begin{aligned}
& \text { A reflexão sobre arquitetura, enquanto crítica da ideologia } \\
& \text { concreta, realizada a partir da própria arquitetura, não pode } \\
& \text { senão ir além e alcançar uma dimensão especificamente } \\
& \text { política, da qual a destruição sistemática das mitologias que } \\
& \text { lhe sustentam o desenvolvimento é apenas um dos objetivos: e } \\
& \text { somente as condiçôes futuras da luta de classe darão o modo } \\
& \text { sde saber se isto que determinamos é tarefa de vanguarda ou } \\
& \text { de retaguarda. }{ }^{196}
\end{aligned}
$$

$\mathrm{Na}$ versão publicada pela Laterza, as mesmas ressalvas do caráter político do texto se mantêm, mas o final tem um conteúdo mais ligado às questões da arquitetura:

$$
\begin{aligned}
& \text { Neste sentido, a crítica sistemática das ideologias que } \\
& \text { acompanham os fenômenos do desenvolvimento capitalista } \\
& \text { não é mais do que um capitulo de tal ação política. Não } \\
& \text { esquecendo que a crítica da ideologia tem hoje uma tarefa } \\
& \text { toda voltada para eliminar mitos impotentes e ineficazes, a } \\
& \text { que recorre, na maior parte das vezes, como a miragens que } \\
& \text { permitem a sobrevivência de 'esperanças projetistas' } \\
& \text { anacrônicas. }{ }^{197}
\end{aligned}
$$

Quatro anos separam as duas versões do texto. A conclusão que prevaleceu foi esta de "Projeto e utopia", que seria amplamente traduzida para cinco línguas, firmaria o autor nos debates internacionais de história da arquitetura e tornaria o Instituto referência para os intelectuais dos anos setenta. O que muda entre uma e outra é o

\footnotetext{
${ }^{196}$ Idem, p. 79.

${ }^{197}$ TAFURI, Manfredo. Projecto e utopia. Op. cit. p. 122.
} 
desprendimento da situação presente para a criação de uma linha institucional menos ligada aos debates da esquerda italiana. Eliminar mitos importantes e ineficazes, desta vez sem o atrelamento à luta de classes ou à perspectiva de qualquer modificação radical. Não é surpresa que os estudos sobre os Estados Unidos, o lugar do mais avançado capitalismo, ganha a frente dos debates do Instituto, como modo de colaborar a um projeto na disciplina da história da arquitetura de longo prazo, sem ter o pano de fundo de uma revolução vindoura. De 1973 até 1976 os cursos ministrados por Tafuri serão exclusivamente acerca dos Estados Unidos ${ }^{198}$. A União Soviética tinha sido tema de seu curso letivo em 1971 e 1972, "Vanguarda, cidade e planificação na União Soviética (1917-1937), justamente o ano de lançamento do volume conjunto do Instituto ${ }^{199}$.

Os textos sobre a União Soviética sofrem o peso dos textos publicados por Tafuri e seus colegas do Instituto nas revistas de esquerda que lhes formaram o trabalho intelectual dentro do engajamento político. $\mathrm{Na}$ formatação de seu texto, provavelmente em 1972, Tafuri estava há cinco anos na cátedra de História da arquitetura, com seu departamento consolidado. Fazia dois anos que a revista Contropiano parara de circular, estando o autor romano já completamente ligado ao cotidiano de professor e historiador de arquitetura.

Ao afastamento de um engajamento político urgente, é concomitante o afastamento da questão soviética em detrimento da americana. As pesquisas sobre os Estados Unidos não eram novas: vide seu curso em 1969-70, “Arquitetura, cidade e plano na América". Mas o abandono de uma por outra é mais evidente, como fica clara uma outra parte modificada no seu artigo de 1969 para o livro de 1973:

\footnotetext{
198 1973/74, "Struttura e architettura nella città terziaria in America (1850-1974)", 1974/75 "Lo sviluppo urbani negli Stati Uniti (1780-1974) e il problema dell'housing", 1975/76 "Il grattacielo e la struttura della città terziaria in America e in Europa (1850-1975)", Cf. ROSA, Federico. Progetto e critica dell'urbanistica moderna: I primi anni di attivita' di Manfredo Tafuri. Op. cit.

199 A partir de 1973, a Rússia entrará nos cursos como mais um objeto de estudo nos temas panorâmicos ("Avanguardia e architettura: le avventure del linguaggio nella città contemporanea", em 1976-77 e "Le avventure dell'avanguardia" em 1979-80) do que como foco monográfico. Mesmo na publicação de artigos, sobra em sua bibliografia os artigos "Verso la città socialista: ricerche e realizzazioni nell'Unione Sovietica, fra la NEP e il primo piano quinquennale, In: Lotus. n. 9, 1975, pp. 76-93, e URSS 1917-1978, la città, l'arcbitettura, estudo bilíngue feito com Marco De Michelis e JeanLouis Cohen, Roma: Officina, 1979. O longo artigo sobre a União Soviética e a Alemanha publicado em La sfera e il labirinto (1980) é revisão de um texto publicado em 1972 numa revista francesa: "URSS-Berlin, 1922: du populisme à l'internazzionale constructiviste". In: VH101. n. 7-8, 1972, pp. 53-87.
} 
O fato desta nova situação profissional - já real em países de capitalismo avançado como os EUA, ou de capital socializado como a URSS - ser temida pelos arquitetos e esconjurada com as contorções formais e ideológicas mais nevrótica, é apenas um indicio do retrogradismo politico de tal grupo intelectual. ${ }^{200}$

No livro ficou:

O fato desta nova situação profissional, já real em países de capitalismo avançado, ser temida pelos arquitetos $e$ esconjurada com as contorçôes formais e ideológicas mais nevrótica, é apenas um indicio do retrogradismo politico de tal grupo intelectual. ${ }^{201}$

Uma hipótese para este 'corte' - que foi claramente fruto de uma revisão mais mediada acerca do texto - pode ser o fato de que os estudos sobre os Estados Unidos careciam, para ter legitimidade dentro dos debates na Itália, ter uma margem de comparação com o grande bloco econômico do oriente, deveria se inserir dentro deste dualismo que, apesar das críticas ao Stalinismo, faziam a União Soviética possuir alguma relevância no cenário político, mesmo no campo estético. O último capítulo de "Projeto e utopia" olha para o futuro do Instituto, lança menos perspectivas apocalípticas para a arquitetura quanto alternativas profícuas para o estudo de história da arquitetura não italiana. Apontava para outras cidades longínquas e que poderiam ser objeto de empenho.

A relação entre os Estados Unidos e Tafuri teve duas vias. A publicação de "Projeto e utopia" ganhou tradução para o inglês e chamou a atenção de diversos intelectuais do novo continente, criando uma ponte entre Itália e Estados Unidos que

\footnotetext{
${ }^{200}$ TAFURI, Manfredo. "Per una critica dellideologia architettonica". Op. cit. p. 77.

${ }^{201}$ TAFURI, Manfredo. Projecto e utopia. Op. cit. p. 120.
} 
respondeu pelas publicações famosas de Tafuri sobre política e arquitetura nos anos setenta, especialmente na revista editada por Peter Eisenman, Oppositions ${ }^{202}$.

Assim como na União Soviética, Tafuri começa seus estudos sobre a América partindo da condição de 'liberdade' dos parâmetros e significações vigentes das preceptivas europeias. Entretanto, nos estudos russos tinha-se um recorte bem definido, partindo de 1917. A Rússia pré-revolucionária chegara a ser alvo de alguns estudos, mas sempre periféricos ao foco do Instituto. Sobre a questão americana, Tafuri tinha interesses mais amplos do que a pujança econômica no presente. Já em "Por uma crítica", Thomas Jefferson aparece como personagem principal na história da fundação de Washington, como o líder que precisa dar forma à uma capital fundada com princípios ao mesmo tempo arraigados na Europa, mas sempre compromissados com a ideia de desprendimento. A saída escolhida é o pastiche, uma cópia da morfologia clássica extraída de contexto para criar uma abstrata ideia de "valores".

Conforme o autor romano, "Em Washington, permanece a referência nostálgica aos valores europeus, concentrados precisamente na capital de uma sociedade que se orienta através da sua corrida ao desenvolvimento econômico e industrial, para a destruição concreta, real, motivada, desses valores." ${ }^{203}$

A referência à Washington vem como final de uma argumentação bem conhecida de Tafuri acerca do papel destrutivo das linguagens iluministas sobre a cidade. Desde Piranesi e seu "Campo de Marte”, tem-se o ápice de um esvaziamento de significados das formas que, no século XVIII ainda resistiam a manter sua carga simbólica (as Ordens e proporções como detentores de uma significação cívica etc.). Enquanto na Roma de Piranesi a fragmentação é potencializada pelo próprio tecido da cidade tardobarroca, nos Estados Unidos o que se tem é um efeito similar, mas com um contexto oposto: aqueles capitéis, cúpulas, colunatas dispostos na geométrica disposição da capital, soltos no território americano, sofrem do mesmo esvaziamento. Pior: tornam-se uma memória vaga do continente antigo, tomando para si um valor nostálgico. Uma nostalgia ambígua, já que ao mesmo tempo em que cita o passado,

\footnotetext{
${ }^{202}$ TAFURI, Manfredo. “European Graffiti': five $\mathrm{x}$ five = twenty-five. In: Oppositions. n. 5, 1975, pp. 35-74; TAFURI, Manfredo. "The dialectics of the Avant-Garde: Piranesi and Eisenstein". In: Oppositions. n. 11, 1977, pp. 72-80. Para a relação de Tafuri com os Estados Unidos: OCKMAN, Joan. "Venice and New York", In: Casabella. n. 619-620, 1995.

${ }^{203}$ TAFURI, Manfredo. "Per una critica dell'ideologia architettonica". Op. cit. p. 31.
} 
cinde pela sua inserção no território livre qualquer significação genuína que esta forma pudesse ter na Europa.

A história da fundação da capital dos Estados Unidos, provavelmente estudada por Tafuri em 1969, quando seu curso semestral em Veneza versava sobre os EUA em um recorte amplo (1500-1970), aborda a liberdade da tradição europeia. Os Estados Unidos - que foram objeto de estudo por muito tempo na carreira do autor - entram como uma das várias nações para as quais a questão da forma e significação sofre um abalo imediato pela sua condição de distanciamento.

A leitura de Tafuri dos Estados Unidos é sempre informada por esta postura de Jefferson, de usar os símbolos do velho continente para subvertê-los criando um novo, contrapondo-os a uma natureza vasta. Seus interesses por Louis Kahn aparecem nesta mesma senda. Na sua busca por criar uma 'nova ordem', o americano acaba por tentar, através da forma moderna, criar o que o autor romano chamava de "recuperação da dimensão do mito" ${ }^{204}$.

Segundo o autor, os mitos são “ideias, forças necessárias e indispensáveis para forçar a situação" 205 .

O conceito certamente é análogo às considerações de Barthes acerca do mito, como uma fala que deforma a existência original de um conceito para vestir sua forma de uma nova função, eterna, de consolidar as estruturas do presente ${ }^{206}$. O mito não esconde nada: tem como função deformar, e não desaparecer" ${ }^{207}$. Não se trata de uma invenção, ou de uma interpretação outra. Tal deformação reside exatamente ao que concerne o seu registro mnemônico. "Tornando-se forma, o sentido agasta a sua eventualidade; esvazia-se, empobrece, a história evapora-se, permanece apenas a letra. Efetua-se aqui uma permutação paradoxal das operações de leitura, uma regressão anormal do sentido à forma, do signo linguístico ao significante mítico.”208

\footnotetext{
${ }^{204}$ TAFURI, Manfredo. “Les bijoux indiscrets”. In: Five Architects N.Y. Roma: Officina, 1981, p. 7. Este argumento pode ser encontrado também em La sfera e il labirinto. Op. cit. p. 293.

${ }^{205}$ TAFURI, Manfredo. Teorie e storia dell'architettura. Op. cit. p. 21.

206“'Tornando-se forma, o sentido afasta a sua eventualidade; esvazia-se, empobrece, a história evaporase, permanece apenas a letra. Efetua-se aqui uma permutação paradoxal das operações de leitura, uma regressão anormal do sentido à forma, do signo linguístico ao significante mítico.” BARTHES, Roland. Mythologies. Tradução para o português: Mitologias. Rio de Janeiro: Difel, 2007, p. 208.

${ }^{207}$ Idem, p. 213, grifo de Barthes.

${ }^{208}$ Idem, p. 209.
} 
O endosso da história dos EUA como mitológica, como formulação de um conjunto de falas a-históricas não é vista de modo negativo por Tafuri na história de sua fundação. O problema da América no século XVIII parecia o das vanguardas e sua cruzada anti histórica no princípio do XX, na Europa. Mas ali, nos Estados Unidos, o caráter mitológico buscava criar uma memória postiça da presença dos americanos no continente. Esta postura existe como referência para os arquitetos do país, e tal necessidade fez com que o autor fosse menos crítico acerca dos pastiches, releituras e ecletismos que eventualmente surgiram na história americana. A crítica à Kahn, como veremos, é parte de um arcabouço geral de leitura negativa das correntes ditas pósmodernas como Eisenman, Hejduk, Meier e outros.

$\mathrm{O}$ que mais intriga o autor romano na história dos Estados Unidos, entretanto, não são as cidades mitológicas, os jogos para se criar uma "nova ordem". O mais importante tema de pesquisa do autor, que o levou sempre a voltar para a América ao longo de sua carreira é, sem dúvida, o arranha céu. $\mathrm{O}$ arranha céu é eminentemente não europeu, é uma subversão total da 'dimensão urbana' e ao mesmo tempo um problema novo em termos de forma. Pouco importam as leituras negativas que Tafuri fará em artigos como "As cinzas de Jefferson" ou "A dialética do absurdo"; fica clara em monografias como "A montanha desencantada" o fascínio do autor pelo modo como, através dos estudos do arranha céu, pode-se chegar a novas considerações acerca da contemporaneidade.

Em 1973, mais uma vez o Instituto lança um livro compilando ensaios, desta vez sobre os Estados Unidos. "A cidade americana da guerra civil até o Nerw Deal" tinha uma divisão muito clara dos temas estudados pelos quatro historiadores do Instituto - um primeiro escalão formado pelo próprio Tafuri, Francesco Dal Co, Giorgio Ciucci e Mario Manieri Elia. Os quatro pesquisariam a tomada do território, o City Beautiful, os parques e as elucubrações de Frank Lloyd Wright na sua Broadacre city. O autor romano rogou para si a tarefa de escrever sobre os grandes edifícios que marcavam a paisagem americana.

"All the world loves natural beauty". Tafuri citava o livro Manhattan transfer para mostrar o dilema territorial americano como indissociável do diálogo com a natureza. Aqui ainda temos a sombra de Jefferson e a cidade de Washington pairando sobre o tema. O arranha céu aparece na prosa de Tafuri como um ser híbrido - 
portador de uma inadequação visceral. Para o autor, estas grandes estruturas existem como um "elemento mediador", algo que marca imediata distância da cidade. Qual a outra ponta de seu hibridismo? O italiano via uma emulação de gigantes naturais, maciços como montanhas. Não à toa, ao escrever sobre o "Manhattan 1950" de Raymond Hood, refere-se a estes como uma solução da qual:

\begin{abstract}
É inútil se perguntar sobre o valor intrinseco da proposta de um ponto de vista estritamente funcional. A finalidade do projeto não é dar soluçôes, mas oferecer, ele também, uma imagem da ideia da City como ordenada cadeia de montanhas, tema na ordem do dia no debate sobre a reorganização dos centros terciários. ${ }^{209}$
\end{abstract}

Tal descrição pode ser mal lida como uma ingenuidade de Tafuri acerca dos grandes edifícios. Na realidade, sua formação na Itália e sua prática profissional já eram marcadas pelo projeto de arranha céus - não se pode esquecer o debate em torno da "Nova dimensão" na Itália formulou respostas amplamente ligadas às mega estruturas, como projetos de Quaroni, Superestudio e do próprio Tafuri e seu AUA, durante os anos em que teve escritório com seus colegas. A comparação com montanhas, feita pelo autor, é menos um comentário ingênuo do que estratégico: era preciso dar a eloquência de quão distante dos tecidos históricos europeus é o arranha céu.

Tanto é que na sua prosa sobre os edifícios altos, deixa clara a inabilidade dos autores europeus de formularem novas respostas sobre os problemas da relação formal entre arranha céu e tecido urbano. Ao escrever sobre o concurso da sede para o jornal Chicago Tribune, o autor analisa quase todos os projetos. Ao comentar as propostas de Gropius, Meyer e de Hilberseimer - francamente ligadas às postulações das vanguardas soviéticas - Tafuri os descredencia rapidamente pela abordagem excessivamente funcional. Admite que aquelas premissas “antecipam prodigamente, de uma ou de outra forma, o que será a linguagem dos arranha-céus após os anos 30,

\footnotetext{
209 TAFURI, Manfredo. "La montagna disincantata". Tradução para o espanhol "La montaña desencantada: rascacielos y la ciudad". In: La ciudad americana: de la guerra civil al New Deal. Barcelona: Gustavo Gili, 1976, p. 462. Grifo de Tafuri.
} 
mas nenhum deles se mostra capaz de enfrentar as questões estruturais que esta tipologia pôs em crise." 210

Para o historiador, o problema era sobretudo de conciliação formal: o funcionamento da cidade é menos importante aqui do que os significados que advém de uma nova relação entre altos edifícios e térreo. As razões deste recorte ficam ainda mais claros quando, diante da proposta dos alemães, Tafuri vê um recorte demasiado funcional que procura fazer do arranha céu uma "catedral do trabalho". O significado do ferro e vidro aqui é retórico: tornar o edifício uma estrutura autônoma de eficiência acima da metrópole.

Esta interpretação não interessa tanto a Tafuri pelas mesmas razões que o levaram a um desinteresse pela questão soviética: a ideologia do trabalho, a longo termo, deu poucas alternativas à forma da arquitetura. No texto sobre os Estados Unidos, o autor romano chega a comparar esta formulação do arranha-céu como uma estrutura comunitária dentro da metrópole. Em certo sentido, Tafuri via nestes projetos para o Chicago Tribune algo tão utópico e antiurbano quanto os falanstérios de Fourier.

O historiador toma partido não pelo primeiro colocado no concurso (Raymond Hood e sua equipe), mas pelo segundo. O projeto do imigrante Eliel Saarinen tinha motivos ecléticos neogóticos cujo valor compositivo se sobressaia, para Tafuri, através da boa articulação entre o escalonamento telescópico dos elementos verticais, que ficavam mais densos no coroamento de cada volume. Isto criava uma separação clara de cada uma das peças que compunham o arranha-céu, ao mesmo tempo em que as linhas apontavam sempre para a relação vertical que o prédio criava na sua escalada.

Esta era a "montanha mágica"211, citação óbvia de Thomas Mann acerca das seduções (e doenças) que se anunciam neste mundo das alturas. Saarinen aparece como o 'campeão moral' das opiniões de Tafuri sobre o concurso porque foi o que melhor soube compor a relação com as alturas, mais do que com o térreo. A proposta do finlandês era concreta como premissa de arquitetura lançada ao céu - resolvia e aceitava o problema do destacamento paulatino do chão.

\footnotetext{
${ }^{210}$ Idem, p. 414.

${ }^{211}$ Idem, p. 419.
} 
Era a resposta ao problema de uma retórica do arranha céu, cuja referência inexistia em qualquer preceptiva europeia. Saarinen a resolve de modo mais eloquente, mas Tafuri via um mesmo sucesso na proposta vencedora de Hood: conseguir dar uma linguagem de mediação entre cidade construída e natureza livre. Agora, mudou o sentido da elaboração: o térreo é a metrópole, seus tecidos, fluxo de carros, estímulos simmelianos, enquanto o céu é o ponto de fuga, o contato com o ar e sobretudo a vista destacada, alheia, segura e de fora. Escalonar e marcar a verticalidade desta relação, era o modo como nos Estados Unidos solucionou-se esta contraposição, segundo o autor.

O artigo mostra depois como Saarinen trabalha na relação entre térreo e arranha céu, ao projetar conjuntos corporativos em Chicago. Mas tais elucubrações servem apenas para sustentar o ponto nevrálgico do raciocínio de Tafuri que já se entrevia nestas primeiras linhas de seu ensaio: "A 'eloquência' das 'montanhas mágicas' de Saarinen está condicionada por serem espectadoras da cena urbana." ${ }^{212}$

O arranha céu, assim como o periscópio de Le Corbusier na cobertura De Beistegui em Paris, tem uma força de espectador, da visão isolada da cidade. É certo que o periscópio é uma visão mediada por um instrumento técnico, enquanto o arranha céu media algo mais do que a visão, mas a própria relação da cidade com a natureza. A organização do térreo desenhada por Saarinen, depois trabalhada pelos Associated Architects no Rockefeller Center, que cria amplos espaços livres que articulam e legitimam a autonomia de cada torre, cria um lastro para o voo do arranha céu.

A visão negativa dos arranha céus, as críticas mordazes acerca do conjunto de prédios que silenciosamente pairam autônomos do conjunto da cidade, são advindas sobretudo do desligamento da tipologia desta função mediadora. As autonomias dos edifícios não são mais em direção a um céu naturalista, libertário do novo continente, mas em um jogo de torres próximas e solitárias. "Os novos arranha céus já não estão no deserto, mas no interior da cidade, ainda que recusem ser parte dela”. Aos modos de uma fábula, o artigo conclui com a imagem do gorila gigantesco King Kong, personagem do cinema que morre no topo do Empire State Building. Ali, no topo, o gorila representava justamente este céu livre, o "bom selvagem" que habitava no alto das mais espetaculares produções tecnológicas arquitetônicas.

\footnotetext{
${ }^{212}$ Idem, p. 433.
} 
Mais uma vez, a questão do espectador ressurge, agora no auge do capitalismo industrial durante os anos setenta. Não tanto o protagonista é tema destas linhas de Tafuri (ainda que King Kong tenha sua dose trágica transferida para os arranha céus). A questão são os bancos da plateia. Diante de uma impotência das vanguardas europeias (e soviéticas) em resolver o drama metropolitano, os Estados Unidos aparecem com uma estrutura que, para além das grandes pesquisas sobre economia política e urbanismo feitas no Instituto veneziano, criou uma cadência de vistas para a metrópole e seu clamor pelo trabalho e organização social nutrindo-se de todas as contradições que nela ocorrem. Em "Esfera e o labirinto", Tafuri admite que Hollywood é uma importante referência como realizadores dos sonhos das vanguardas, especialmente Forty Second Street, onde segundo o autor:

Em Forty Second Street, as cantoras estão fantasiadas como no Parade ou no Balé Triádico. Mas ali as máscaras são criadas pela realidade urbana: as silhuetas dos prédios de Nova Iorque dançam otimistas - bem no meio da Depressão - ao longo da inevitável escadaria... ${ }^{213}$

Inseridos na malha, mas como ponto de observação e baliza visual. $\mathrm{O}$ arranha céu é uma das mais importantes estruturas de leitura da cidade presente nos textos de Tafuri sobre a arquitetura contemporânea. Se Benjamin fez um longo trabalho acerca das deambulações pela metrópole europeia, pela morte da experiência nas ruas concomitante a uma 'crise' da visualidade, Tafuri viu que no alto de Manhattan existe um novo capítulo da contemporaneidade, que é aquela cidade sem ruas existente no topo dos edifícios. A visão se tornou preponderante nas suas argumentações. Nos Estados Unidos, faltam pontes, e isto se aplica no plano metafórico. Em "As cinzas de Jefferson", artigo que foi convertido em capítulo conclusivo da "Esfera e o Labirinto", o autor deixa clara a fragmentação de Nova Iorque no topo dos prédios. Manhattan é solitária, sem diálogo e onde a vida não pode ser senão atuada em silêncio ${ }^{214}$. Tal

${ }^{213}$ TAFURI, Manfredo. La sfera e il labirinto. Op. cit. p. 111.

${ }^{214}$ Idem, p. 292. 
opinião é expressada por Tafuri acerca da linguagem dos edifícios, menos do que ao comportamento das pessoas.

Esse mutismo que resulta das autonomas formas das torres em direção ao céu é bem conhecido do autor romano. Sua argumentação sobre os arranha céus recai no esvaziamento do mito americano, cujo trabalho de Kahn, depois de Venturi e Eisenman colaboraram, cada um à sua maneira, para atestar. "A guerra acabou”, diz o autor romano, acerca dos jogos formais dos Five Architects - e os pastiches subsequentes deste 'novo purismo' aparecem em representações caricatas da Europa, muito longe da intenção de criar novos significados, mas apenas de ironizar a possibilidade de um território livre da história, fundada em princípios tão apriorísticos, conforme Jefferson intentava fazer com a sua capital.

A história do arranha céu que Tafuri nos traz chega nos anos setenta - o 'presente' - no mesmo fim de linha que as correntes europeias. Entre União Soviética e Estados Unidos pode-se ver uma construção afinal similar, de aliança entre vontade de libertação dos parâmetros europeus por um mergulho no avanço tecnológico e urbanismo gigantesco que pouco a pouco se esgota, terminando no mutismo e hermetismo.

Até mesmo nesta 'nova' mitologia, os problemas reaparecem. É certo que, enquanto havia certa repetição nas conclusões, o Instituto aprofundava e profissionalizava cada vez mais a sua capacidade de engendrar novas interpretações para temas exaustivamente estruturados pela historiografia mais regulamentar de arquitetura. Entretanto, vendo os estudos do Instituto das grandes economias do século XX, não existe outro caminho interpretativo: a chave é negativa. As vanguardas e as correntes americanas chegam ao tempo do autor como uma irritante repetição de temas e falta de ímpeto para enfrentar o encalhe da arquitetura na figuração - ainda que imagética - das cidades. Durante os engajados anos sessenta, ainda se podia ter a esperança de uma ferrenha atuação política - e em certo sentido até sugerir um sensível atrelamento da questão estética à econômica. Porém, em meio aos anos setenta, já desprendido de uma urgência revolucionária, a questão da metrópole parecia estar de fato, para Tafuri, em um impasse.

É certo que o autor tinha simpatia por algumas correntes e arquitetos especialmente aqueles do círculo romano de arquitetura contemporânea, como 
Gregotti e Rossi. Escreveu pelos princípios dos anos noventa textos elogiosos à Stirling e assumira, apesar do tom sombrio, que existia espaço para novas arquiteturas. Via de regra, entretanto, estes hiatos da postura crítica do italiano apareciam longe dos grandes fluxos do capital. Nos anos noventa, já se delineava o surgimento de grandes escritórios de arquitetura internacional 'de autor' - o que viria a ser chamado o Star system - e a estes Tafuri sempre dirigiu severas críticas, haja visto as acusações de cinismo feitas a Rem Koolhaas ou a sua luta feroz contra as reformas de Renzo Piano em Veneza.

Entretanto, seus estudos sobre as grandes metrópoles do capitalismo americano recaem em uma estranha analogia: “...Na verdade, Nova York é - ao menos a partir de 1890 em diante - uma alegoria de Veneza nos tempos modernos.”215

As cidade de ponta do capitalismo ganha nova importância na prosa do autor como uma alegoria de Veneza. Que analogia se sustentaria nestas cidades tão distintas? Tafuri tinha muita consideração pelas fachadas da cidade dos canais. Em textos como "Veneza e o Renascimento" e "A dignidade do átimo", passa algumas linhas mostrando a tipologia residencial dos Palazzi a partir do '500, expondo a grande flexibilidade da fachada em contraposição ao interior, sempre escondido e imutável. Deste modo, a superfície, a face de Veneza para os turistas, canais e gôndolas veio sendo alterada (até o XIX, quando a cidade finalmente cristaliza-se), enquanto pouco mudou no seu interior. Do mesmo modo é Nova York: sua ampla gama de arranha céus, todos em estilos distintos e que podem ser resolvidos de tantas formas, escondem no seu interior postulações básicas dos prédios escritoriais, como as plantas livres, a relação entre núcleo e pavimento.

A partir daí, o autor pode livremente tecer imagens como cidades de máscaras, solidões autonomizantes, etc.. Entretanto, o mais importante deste procedimento é menos a comparação alegórica entre as duas cidades do que a retomada do foco nas questões europeias, ou mais além, naquelas mais afastadas da velocidade frenética do capitalismo industrial.

Em um artigo publicado na revista Rassegna, intitulado "A 'nova Constaninopla”, Tafuri mostra como a cidade, durante o '400, foi capital de um vasto império, que poderia competir tanto com a Roma no ocidente, quanto com

${ }^{215}$ Idem, p. 291. 
Constantinopla no oriente. A cidade toma para si esta condição entre Ocidente e Oriente, da qual Tafuri se apropria, para também esquecer a decadência das cidades americanas e usar o seu legado como ideia força para dar novo fôlego ao seu projeto histórico.

Também o Oriente é cheio de 'cidades longínquas'. Entretanto, a aproximação de Tafuri a elas não será literal como foi com os Estados Unidos e União Soviética: não direcionará o Instituto para pesquisas intensivas na Ásia, preferindo direcionar os estudos de seus orientandos mais e mais para a questão do Renascimento e para as desdobramentos periféricos das vanguardas europeias (como as experiências socialistas em Viena). A questão oriental não foi objeto direto de estudos do autor. "Não existia uma seção de oriente em sua biblioteca”, disse sua colega de instituto Manuela Morresi, acerca de seu acervo na casa de Veneza ${ }^{216}$. O Oriente se infiltra, como veremos, como uma romântica construção temporal, um espelho crítico do Ocidente. Leitor assíduo de Giacomo Marramao, é possível que para Tafuri estas linhas do então jovem filósofo tenham sido importantes na sua carreira:

\section{"A antitese Oriente-Ocidente é ... constitutiva da kultur europeia: tem suas raizes no sentido de ausência $e$ incompletude que está na base da pretensão ocidental de moldar o mundo com sua práxis. Pretensão de supremacia, não de centralidade. 'Oriente' é o preço da primazia: aquilo que se perdeu na decisão de transformar o mundo." 217}

Esta construção de Marramao, feita em 1983, pode retroativamente explicar um movimento de Tafuri acerca do Oriente, e a busca de uma sua leitura como contraponto à modernidade, às vanguardas e finalmente, ao esvaziamento que aconteceu com a arquitetura no século XX.

Durante os anos sessenta e setenta o autor escolhia seus recortes sobre arquitetura contemporânea informado por uma estratégia institucional. A decisão fora realmente investigar a origem das cidades que despontavam como centrais no

\footnotetext{
${ }^{216}$ Depoimento de Manuela Morresi feito ao autor em 24/11/2010.

${ }^{217}$ MARRAMAO, Giacomo. Potere e secolarizzazione: le categorie del tempo. Tradução para o português Poder e secularização: as categorias do tempo. São Paulo: Unesp, 1995, p. 160.
} 
socialismo e capitalismo. Entretanto, ao minguarem os anos setenta, as conclusões críticas de seus estudos e uma reorganização da inteligência de esquerda afetam claramente a prosa do autor romano, e não somente em seus recortes de pesquisa, mas voltados para a "boa arquitetura". Os debates versarão menos sobre questões da forma e sua ideologia no processo de consolidação do capital, ou das rebeldias inúteis das correntes pós anos cinquenta, para começar estudos mais calcados em categorias filosóficas em voga durante os anos oitenta, como as pequenas narrativas de personagens (as ditas micro histórias de Ginzburg) e sobretudo, uma aceitação clara do debate acerca do tempo, e da possibilidade de se subverter nas cidades o tempo do capital.

Tafuri muda: os trabalhos sobre o Renascimento se tornam ainda menos literais nas suas ligações com o presente e, como veremos, uma nova ideia de urgência política se molda, distante das perspectivas pré-revolucionários para uma discussão sobre o 'átimo', oportuno.

$\mathrm{Na}$ conferência de 1993, "As formas do tempo: Veneza e a modernidade", o historiador italiano começa pelo estudo da luneta de um portal no Batistério de Parma. Percebe ali representada uma narrativa de tons orientalistas, com a história de um jovem que, fugindo de um dragão, sobe em uma árvore. Abrigando-se, pega um favo de mel que está em um galho próximo. Roem o tronco da árvore, um lobo branco e outro negro, vagarosamente selando o destino do fugitivo. Tal fábula aparece com variações em outras obras, mas a moral a que elas servem ao italiano é o da fruição última, o instante da morte. "Esta primeira metáfora figurativa nos dá, diria, a primeira forma: o tempo do átimo, a dignidade do átimo. (...) É uma forma do tempo que anula o tempo mesmo." 218

Só resta a esta primeira forma o aproveitamento intenso do instante, o fruir do mel logo, como tempo único, sem remeter ao passado ou ao futuro.

Em um de seus saltos, Tafuri buscará então mostrar a forma do tempo presente em um projeto de Le Corbusier em 1930, para Argel, o Plan Obus. O historiador italiano retorna a este projeto tão paradigmático em sua historiografia, para mostrar como ali se entrecruzam três tempos: o da velocidade de percepção, nas auto estradas, na escala do grande volume residencial, 'espelhando-se no

${ }^{218}$ TAFURI, Manfredo. Le forme del tempo. Op cit. pp. 8 e ss. 
Mediterrâneo'; o tempo do consumo, dentro das células residenciais, que figuram nos croquis de Le Corbusier como um espaço livre para modismos e substituições de apliques. O terceiro e último tempo é aquele eterno e imutável da kasbah, sempre marcante nos seus escritos, como testemunho do tempo 'quase imóvel'. ${ }^{219}$

Esta interpretação de Tafuri do Plan Obus não é nada nova em seu trabalho. Le Corbusier aproximava o passado eterno de sua máquina (poeticamente) utilitária: tentava uma conciliação impossível. Conforme Tafuri, esta inadequação, essencial, entre os tempos, era explicitada por Le Corbusier através da "mais trágica das formas que a arquitetura pode inventar: a ponte, vale dizer aquela que nega toda possível relação entre os nossos tempos acelerados cronofágicos e o tempo imóvel...”220

O Plan Obus é chamado à questão a título de contraste: a noção de tempo sobre a qual o historiador italiano quer tratar é verdadeiramente aquela do portal sul do Batistério de Parma, da kasbah, do Monte Athos. Não obstante, procurará fazer um pequeno itinerário iconológico (incomum à seus procedimentos historiográficos) para mostrar como Veneza e seus artistas possuem uma insistência contínua na noção de tempo representada pelo Tricipitium: a alegoria que mostra o jovem, o homem maduro e o velho, em diferentes relações, mas sempre com uma moral constante: o homem maduro é o tempo preciso da ação, é o que possui a capacidade de transformação, posto que o velho não pode senão observar o tempo passado, e o jovem é ainda inato para a tomada de decisões, e somente lhe cabe contemplar o tempo que lhe precedeu.

Em Tiziano, na sua "Alegoria da prudência”, estes tempos interagem de modo ainda mais radical: apropriando-se de lendas orientais, alia às figuras humanas o lobo, o leão e o cão. O velho tem sob si o lobo, que olha para o passado - representa o tempo mastigado, aquele longamente depurado pela passagem da vida: interpretado, rasurado, revisto. O leão e o homem maduro são ladeados na sua força - átimo de ação. O cão, figurado junto ao jovem que olha para o futuro, é representado pela fidelidade - o prosseguimento da tradição, lealdade. "O olhar fixo sobre a possível

\footnotetext{
${ }^{219}$ Idem, p. 9.

${ }^{220}$ Idem, p. 11.
} 
representação de início e a fidelidade do cão que olha para o futuro, fiel àquela vontade de início."221

Este tempo é o cíclico, aquele em que tudo eventualmente torna a atualizar sua origem, através de uma condição imutável. Não será necessária muita deambulação teórica para contrapor este ciclo àquele outro, de contínuas rupturas, da 'tradição do novo', a que Tafuri, leitor de Rosenberg, se referira continuamente nos seus estudos sobre a contemporaneidade. Não foi a vontade das vanguardas apagar os rastros do passado ao romper com a história da arte anterior, rotulando-a em bloco como acadêmica e anacrônica?

Para o italiano, Veneza é inadequada aos tempos da modernidade. Onde prevalece a prudência, a ruptura tem alcance restrito: não alcança a própria essência do tecido histórico, não consegue rasgá-lo com o progresso. Tafuri retorna à kasbah do Plan Obus: “Àquele tempo [o da modernidade] não queria, Le Corbusier, misturar o tempo lento ao qual tinha renunciado; pois que o tempo lento ou o tempo imóvel é o tempo místico, portanto, como buscarei demonstrar à guisa de conclusão, tempo necessário à contemporaneidade”. ${ }^{222}$

Coerente com seus textos anteriores sobre Le Corbusier, o conferencista tece um elogio à suas tentativas de conciliação com o imutável - a explicitação de uma crise imanente à crise do objeto. Chandigarh e Argel são dois exemplos eloquentes desta faceta da obra de Le Corbusier. O ponto de vista que se quer comprovar, entretanto, é o fracasso de qualquer aproximação da modernidade com o passado. Finalmente, toda esta deambulação termina em uma ponderação acerca da negatividade imanente da era de técnica:

“A nossa modernidade, que viu a guerra guerreada entre máquinas na Primeira e Segunda guerras mundiais, que é capaz de salvar as vidas dos homens com refinadíssima técnica cirúrgica, mas que ao mesmo tempo é capaz de destruir milhões de homens com técnicas igualmente refinadas, vive do desprezo de si mesma. (...) E esta negação não é o outro, não é contra o moderno, mas é o seu motor."223

Estas conclusões servem para legitimar, portanto, as buscas pelo tempo que não neguem a si, pela busca de uma conciliação com o passado através da prudência.

\footnotetext{
${ }^{221}$ Idem. p. 12.

${ }^{222}$ Idem. p. 29.

${ }^{223}$ Idem. p. 31 e ss.
} 
Tafuri reafirma suas conclusões em Machine et memoir, mas agora apontando a modernidade como projeto inacabável. Justifica-se aí a ausência, em sua obra, de esperanças redentoras sobre as quais tanto se contorceram as gerações ditas pósmodernas para dar verniz positivo a uma força eminentemente negativa. A busca deste tempo do átimo não é programática - como eram as considerações de Benjamin acerca de arte e técnica. Justifica-se esta ausência de articulação concreta com a arte do presente por propor o oposto à urgência: a longa duração das ações, a prudência.

"O tema da prudentia era, em Veneza, importante. Era a prudência que garantia a persistência de Veneza dentro de sua origem; prudência constituía a medida do 'bom governo', fundou critérios de justiça, permitiu a tradição resistir dentro do novo, e conseguiu que este novo vivesse em um ininterrupto tempo cósmico.”224

Sua admiração por Veneza, portanto, não é elogio à recuperação da temporalidade sacra na arte: é o da restauração da reflexão. Tal reflexão seria a porta de entrada para se ultrapassar o âmbito da imediatez e se intuir a totalidade. ${ }^{225}$ Para o historiador italiano, a única maneira de se subverter o sem-fim de fragmentadas visões de realidade seria a retomada do átimo.

É certo que o Oriente, tal como Tafuri o lê, é visto como um lugar mágico onde o tempo permaneceria estático, monolítico. Certo é que em nada no projeto de Le Corbusier isto se atesta para além das aparências. O memorial de Le Corbusier tem planos para a kasbah, prevê a remoção de um trecho dela (então o mais recente), e tem zoneamentos. Tais previsões procuravam restaurar a rotina do bairro aos seus usos originais - algum comércio anterior ao moderno etc. mas isto não é impeditivo aos comentadores de Le Corbusier acusarem em Tafuri uma leitura rasteira do Oriente:

"Tafuri vê no tratamento de Corbu da kasbah um 'modelo atemporal... metáfora de um tempo antigo', que é 'estranho ao tempo, estranho ao moderno, indiferente aos seus destinos'. Estas palavras vindas de um dos mais perspicazes historiadores de nossos dias pertencem, paradoxalmente, à tradição Orientalista que atribui atemporalidade e existência pré-histórica à cidade Islâmica, negando sua

\footnotetext{
${ }^{224}$ TAFURI, Manfredo. Venezia e il Rinascimento. Tradução para o inglês: Venice and the Renaissance. Cambridge/Londres: The MIT Press, 1995. p. 11.

225 "Explosão do imediato, abertura advinda como uma reflexão originária, objetivação da consciência pela estruturação do passado: são formas diferentes de indicar as condições de possibilidade de desencadeamento de um processo de mediação que Hegel chama de História, esse lugar de produção do universal ou, o que é a mesma coisa, de manifestação da racionalidade (...).” ARANTES, Paulo Eduardo. Hegel, a ordem do tempo. São Paulo: Hucitec, 1981, p. 204. Grifos do autor.
} 
mudança e processo, acentuando a diferença entre o dinamismo do moderno Europeu e o êxtase do antigo Islã." 226

Do mesmo modo, sua leitura de Veneza ampara-se em símbolos advindos da China - cuja circulação passa pela Arábia. Em Chandigarh faz menção às cadeias do Himalaia e às tradições indianas... Se o átimo é o que ficou para trás do mundo oriental, é verdade que Tafuri nunca advogou diretamente por uma maior atenção a ele. Seus escopos de trabalho privilegiaram a Europa (e na contemporaneidade, a América e, por vezes, o Japão). Demonstrou pouco interesse no estudo da periferia do movimento moderno e sua difusão - América Latina, Ásia, África. É estranho, portanto, que Tafuri deposite tanta esperança em um assunto sobre o qual escreveu tão pouco.

Nada pode salvar a visão da temporalidade oriental em Tafuri como ingênua, pouco arraigada na realidade e contrastante com o rigor filológico que ele advogou ao longo de sua carreira. Cinco anos antes já estava em circulação a obra de Edward Said Orientalism, voltada para a investigação acerca dos interesses europeus no Leste, vizinho geográfico, sedutor como testemunho de épocas e costumes imemoriais. "O Oriente não é apenas adjacente à Europa; é também o lugar de suas maiores, mais ricas e velhas colônias, a origem de suas civilizações e linguagens, seu competidor cultural, e uma das mais profundas e recorrentes imagens do Outro."227

Este romantismo - que em Said tem o valor de diagnóstico - abertamente tem usos em Tafuri na construção de origem na sua leitura da modernidade. Redunda-se na noção de origem como turbilhão, como Benjamin bem a entendia. O Orientalismo de Tafuri deve ser lido sob este pano de fundo: é uma imagem precária justamente porque seria impossível formalizar em seus textos mais positivos a ideia precisa do que seria este tempo de eternidade. Ele é mitológico, posicionando-se, portanto, no ponto cego de seu rigor.

O Oriente como uma representação do tempo eterno, da contraposição às aventuras aceleradas da modernidade. É provável que, para Tafuri, a resistência à modernidade só adviria através da busca de um dilema primordial, perdido em uma zona misteriosa, cuja intuição só seria possível através do árduo exercício histórico.

\footnotetext{
${ }^{226}$ ÇELIK, Zeynep. "Le Corbusier, Orientalism, Colonialism". In. Assemblage, 17, abril de 1994, p. 70.

${ }^{227}$ SAID, Edward. Orientalism. New York: Vintage, 1979, p. 2.
} 
Desse modo, no limite de suas investigações, nas cidades longínquas, não hesitou em desprover-se de suas ferramentas da crítica para construir uma imagem totalizante que deliberadamente criava um ruído em seu trabalho, e afinal mostrava que a história só apareceria em lampejos parciais, nunca no final da linha. No final da estrada, só resta o mito. Parar a história para analisá-la ponto a ponto era uma tarefa obsessivamente seguida pelo italiano, e ao mesmo tempo supérflua. A irreconciliação de Le Corbusier com o Oriente é um espelho para Tafuri: a verdade, a reflexão e a prudência são valores perdidos para sempre.

Diante disto, não é falacioso reatribuir a Tafuri alguns de seus rótulos mais famosos: de fato, tratava-se de um teórico desencantado, pessimista quanto à contemporaneidade e tremendamente faminto pela busca da origem, melancólico na sua obsessão filológica.

Entretanto, estas interpretações não se sustentam se a leitura de sua obra for feita como portadora de uma informação que ultrapassa os tempos que nela se misturam. Benjamin estabeleceu em "As afinidades eletivas de Goethe" a dicotomia entre o químico e o alquimista. "Se, por força de um símile, quiser se contemplar a obra em expansão como uma fogueira, pode-se dizer então que o comentador se encontra diante delas como o químico, e o crítico semelhantemente ao alquimista. Onde para aquele apenas madeira e cinza restam como objetos de sua análise, para este tão somente a própria chama preserva o enigma: o enigma daquilo que está vivo. Assim, o crítico levanta indagações quanto à verdade cuja chama viva continua a arder sobre as pesadas achas do que foi e sobre a leve cinza do vivenciado."228

O entremeio histórico é a própria estrutura que mantém vivas as esperanças de Tafuri, nas entrelinhas de suas análises, onde todos os dilemas estão compactados. Ali, tem-se a real dimensão da "ponte" que resolve diversos espaços históricos em dilemas antigos. Na realidade, o "átimo" serve nos anos oitenta como alternativa para a mudança de cenário acerca da revolução. "A revolução", dizia Tafuri, inspirado por Hegel, "significa retorno"229. Assim a busca pela origem não é uma condição sempre presente na história do autor: trata-se realmente de uma outra seção de sua política histórica, que diferencia-se dos procedimentos institucionais de crítica à ideologia

\footnotetext{
${ }^{228}$ BENJAMIN, Walter. "Goethes Wahlverwandtschafen". Tradução para o português "As afinidades eletivas da Goethe”. In: Ensaios reunidos: escritos sobre Goethe. São Paulo: Editora 34, 2009, p. 13 e ss. ${ }^{229}$ TAFURI, Manfredo. Carta à Joan Ockman, publicada em Casabella, n. 619-620, p. 67.
} 
feita no princípio de sua carreira dentro do Instituto. As pesquisas sobre a União Soviética e Estados Unidos são bastante distintas, no seu cerne de investigação, que os textos de Tafuri sobre Chandigarh, Argel e Veneza. Entretanto, a hipótese do átimo, da não-modernidade, é um modo de visão histórica atribuível aos grandes centros metropolitanos. $\mathrm{O}$ trabalho do historiador, sempre tão avesso à margens, caminha na construção de pontes, mas assim como as ligações podem ser feitas com variados tipos de materiais, também o rigor filológico e a intuição filosófica são ladeadas na prosa do autor como distintos meios da fatura de suas improváveis conexões. 


\section{As águas de Veneza}

Apesar de ter construído sua carreira como professor entre as vias e campos de Veneza, Tafuri só estudou com profundidade a cidade a partir dos anos oitenta. Três cursos consecutivos no IUAV (de 1981 até 1985) e a publicação dos livros "A harmonia e os conflitos" e "Veneza e o Renascimento" formam um corpus do autor acerca da cidade dos canais, que até então se resumia a uma obra sobre Jacopo Sansovino, publicado em 1969.

A conferência “A dignidade do átimo", de 1993, na qual Tafuri trata das relações entre tempos, é devedora desse período de estudos intensivos sobre Veneza. As questões da Sereníssima são tratadas com um acento pragmático, de tal modo que a frase final da conferência tem o aspecto de chamado às armas: "A batalha ainda não terminou”. Pode-se ler esta conclusão de modo teórico, do confronto entre prudência e imediatismos, persistência das convenções e as rupturas, etc. No entanto o tom dos últimos parágrafos, muito lastreados no presente, criticando o show de Pink Floyd que destruiu Veneza alguns anos antes e a Expo 2000, não deixam dúvidas que a batalha tinha ali também um viés concreto.

$\mathrm{O}$ envolvimento de Tafuri com a cidade não era somente acadêmico. $\mathrm{Na}$ autobiografia publicada postumamente, o autor de "Teorias e história da arquitetura" resumia em um parágrafo suas atividades nos anos noventa: "Por si, [Tafuri] continua o engajamento político, seja dentro da universidade ou como cidadão, combatendo em primeira linha na batalha contra a Expo [2000] prevista em Veneza, e contra os projetos de Renzo Piano para a Basílica de Vicenza."230

\footnotetext{
${ }^{230}$ TAFURI, Manfredo. "Autobiografia”. In: DI MARINO, Orlando (org.). Manfedo Tafuri: oltre la storia, Nápoles: Clean Edizioni, 2009, p. 107.
} 
Esse engajamento contrasta com a interpretação que Tafuri deu às suas atividades nos anos sessenta e setenta - considerados como os mais radicais, pelos comentadores de sua obra. "Projeto e utopia" e outras obras radicais são citadas em termos mais universitários, alegando que "junto aos seus colaboradores, [Tafuri] tentou fundar, entre polêmicas ainda não superadas, a autonomia absoluta da história da arquitetura, em relação ao projeto." ${ }^{231}$

Seu esforço político é colocado sobretudo em dois momentos: sua juventude, como aluno-problema na Faculdade Valle Giulia em Roma, e seus últimos anos de vida, no engajamento pela Serenissima.

“A diginidade do átimo” é um testemunho desse contexto. A arma de seu empenho na defesa de Veneza é a mesma presente em sua prosa ao longo dos anos: a história da arquitetura com uma estilística fragmentada e plena de virtuoses filológicas, na qual períodos distintos são inesperadamente compactados para chegar nos temas do presente. Veneza, por sua vez, destaca-se como protagonista de toda a estrutura da palestra: tanto quanto o tecido e edifícios da cidade, interessa a Tafuri a sua teologia, seus mitos de que ela é, pela sua fundação em meio às águas, ser portadora do tempo eterno.

Tafuri se pauta pelo mito cinquecentesco da origem da cidade dos canais, segundo o qual o dia da sua fundação, vinte e cinco de março, coincide com efemérides ilustres, como a expulsão de Adão e a crucificação de Cristo. Trata-se de uma visão na qual a Serenissima possui a temporalidade absoluta das grandes passagens bíblicas da perda do paraíso e da sagração do messias. O mesmo dia, a mesma cidade: puro átimo decisivo.

Em um momento da conferência, o autor de "Projeto e utopia" levanta a pergunta - retórica - se os venezianos liam a alegoria dos tempos sucessivos como um mito instrumental. Tafuri imediatamente refuta tal hipótese, desdenhando de quem a tome como possível, "tendo já respondido os historiadores da antiguidade, polemizando acerca da inteligência de quem pergunte se os antigos acreditavam em seus mitos.”

$\mathrm{O}$ próprio nome de Veneza vem de sua origem análoga àquela do nascimento da deusa Vênus, que também surgiu das águas. Num cotejamento de lendas pagãs às

\footnotetext{
${ }^{231}$ Idem, p.107.
} 
cristãs, Vênus é, com o tempo, substituída pela virgem: "Veneza", explica Tafuri, "se identifica com Vênus, mas também com a Virgem, enquanto divina, inalcançável e única, livre de muros como utopia platônica, subtraída do tempo moderno e isenta dos pecados de Caim e Rômulo."232

Tafuri se ampara nas documentações feitas pelos vênetos, como Marin Sanudo, Francesco Colonna, Tiziano e Giorgione, para afirmar como é persistente o pensamento atímico na história da cidade dos canais. Desta temporalidade, advém sobretudo sua condição de 'Vênus arrancada do mar'. Veneza construiu uma cultura cujo orgulho e identidade baseia-se nesta sua situação geográfica. Para além das referências de Tafuri, na bibliografia contemporânea de textos sobre Veneza, sobressai-se sua mitologia fortemente ligado às águas. Laurence Wavrin, em um artigo intitulado "Mar e propaganda na pintura veneziana do século XVI", pondera como, durante épocas nas quais o poder da Serenissima era diminuído pelas grandes potências marítimas e suas colônias, ela mantinha sua força pela presença "no mar":

Esta dignidade ideal [de ser imperatriz dos mares] compensava na fiç̧ão o preço pago pela paz com os turcos. Compensa também a concorrência das frotas comerciais portuguesas e espanholas e, brevemente, as holandesas e sua falta de incursões no Novo Mundo. ${ }^{233}$

Assim como as águas dos canais são vistas como todas as águas dos mares, o tempo em Veneza tem uma força de ser o tempo de todo o mundo.

Que o átimo de Tafuri, na ocasião em que proferiu esta conferência, está intimamente ligado à Veneza, não é difícil demonstrar. O passo necessário para compreender os modos pelos quais o instante se espalha por toda a obra do autor de "Projeto e utopia", é ver como essa mitologia é profundamente baseada no seu élan com os mares e, no limite, com a natureza.

\footnotetext{
${ }^{232}$ TAFURI, Manfredo et. alt. "Il mito di Venezia". In: Rassegna, n. 22/2 junho de 1985, p. 7.

${ }^{233}$ WAVRIN, Laurence. "Mer et propagande dans la peinture vénitienne du XVIe siècle". In: CAZALÉ BÉRARD et. al.. La mer dans la culture italienne. Paris: Presses universitaires de Paris Ouest, 2009, p. 228.
} 
Em 1980, escrevendo sobre a cidade dos canais durante a época contemporânea, o historiador analisa a obra temporária de Aldo Rossi em Veneza, o Teatro del mondo. O palco flutuante interessava a Tafuri menos quando estava diante da Punta della Dogana - seu lugar final de atracamento - do que no seu trajeto, desde o canteiro de obras em Fusina até o seu ponto de parada. "O efeito de estranhamento dessa construção, que alude a um mundo de memórias demasiado rico para ser explicitado, multiplica-se no percurso de sua construção e de seu trajeto."234

Para Tafuri, o passeio inicial do "Teatro", uma paródia do campanário de San Marco, contrapõe os períodos e retóricas dos prédios de Veneza. Desnuda cada um dos marcos da cidade: o ensaio fotográfico da "Domus" mostra o teatro diante do Palácio Ducal, da igreja da Salute, do Moinho Stucky. O lento flutuar de seu edifício representa o movimento no tempo da cidade e das suas transformações.

As águas de Veneza aparecem neste pequeno artigo não como força mitológica do isolamento do continente e de seus vícios. Aparece, nesse caso, em uma chave de movimento, do "fazer flutuar". O "Teatro", associado ao caráter efêmero da intervenção, cria o pano de fundo para que se faça saltar ao presente a variedade de símbolos de Veneza como uma cidade hermética à modernidade. "O olhar que abraça esses universos de sinais, sempre configurados como aparições inquietantes, não obtém deles senão indicações herméticas para alimentar sentimentos que envolvem-se em espiral nas profundidades do intransitável." ${ }^{\text {235 }}$

Está claro como a expressão do texto se sustenta em antíteses: máscaras e desvelamento, efêmero e eterno, fixo e móvel, etc. Antes de seus estudos sobre Veneza, portanto, o historiador já intuía nela uma condição atemporal. As águas, no entanto, são outras: menos ligadas ao mito original e mais conectadas à noção existente entre superfície aquática e transitoriedade. As águas como imagem do tempo aparecem de modo heráclito, numa condição em que "tudo flui".

Esse fio de temporalidades aquáticas tem ecos em outras pesquisas de Tafuri. Vimos como em seu curso sobre Borromini, ministrado entre 1978 e 1979, existe um momento de introdução teórica, no qual duas aulas são dedicadas à fundamentação: especificamente, no estudo de Walter Benjamin em sua obra sobre o barroco, uma

\footnotetext{
${ }^{234}$ TAFURI, Manfredo. "L'ephemere est eternel. Aldo Rossi a Venezia". In: Domus, n. 602, 1980, p. 8.

${ }^{235}$ Idem, p.8.
} 
grande construção teórica que inspirará os anos de maturidade do historiador, tanto na sua busca por protagonistas arquitetos na 'tragédia' das cidades, como em sua escolha por momentos de inflexão da cultura humanista que ainda lançam questões ao presente.

Essa introdução, no entanto, não termina nessas duas aulas. Antes de abordar os trabalhos de Borromini, Tafuri ainda lecionou sobre um nome da arquitetura do Renascimento, uma "figura sintomática" que conseguiu "apresentar a racionalidade como suprema irracionalidade e o inverso, apresentar a irracionalidade como supremo racional"236: Leon Battista Alberti.

As duas aulas sobre Alberti no curso de Borromini de 1978 já anunciam a senda de textos importantes que Tafuri publicaria sobre este autor capital: a contraposição entre obras de viés positivo, como os seus tratados, e outras narrativas negativas, como Momus e Teogenius. Na construção dessa imagem do arquiteto humanista, Tafuri detém-se nos Intercoenales, apanhado de pequenos textos assinados por Alberti, sobretudo num intitulado Sognum, a narração literária de um sonho. $\mathrm{O}$ filósofo sonhador se vê entre montanhas por onde flui um rio "digno de maravilha" 237 . As águas são tenebrosas: ao invés de ondas, forma rostos humanos, uma multidão anônima. A experiência de atravessar esse rio onírico é tortuosa, o viajante deve girar em torno de si enquanto é mordido pelos vultos. "Mas o que estava além do rio?" Tafuri citava Alberti para a sua classe, "Algo digníssimo de história. Estão entre os montes vales nos quais conservamos as coisas perdidas." Conclui o professor: "Eis o objetivo [da transposição]: reencontrar a memória. É necessário passar aquele rio para não se ter, em certo sentido, nostalgia da infância, reencontrar todas as coisas perdidas, a vida inteira do sujeito." 238

Tafuri faz essa narrativa tendo como pano de fundo suas lições sobre Benjamin e seu vórtice que traga todo o devir do tempo à origem. No entanto, existe ainda um outro rio. Uma pocilga, esse rio só pode ser atravessado montando nas costas de uma anciã disforme. E o que existe na outra margem deste? "Nada menos do que uma

\footnotetext{
${ }^{236}$ TAFURI, Manfredo. "Francesco Borromini e la crisi dell'universo umanistico, 1978-79", Op.cit. p. 42.

${ }^{237} \mathrm{Idem}, \mathrm{p}$.

${ }^{238} \mathrm{Idem}$, p. 56.
} 
planície na qual se deveria finalmente encontrar não mais a vida passada, mas a verdade." ${ }^{239}$

Tal verdade, no entanto, não é explícita e nem mesmo apreensível. Essa margem é cheia de emaranhados de cabelos, crinas e pêlos, que deuses caídos comem e assim alcançam a verdade. No entanto, quando o protagonista do Sognum busca pelas raízes dessas cabeleiras, piolhos gigantescos o atacam, e o sonho termina.

De acordo com Tafuri, esses sonhos servem para mostrar como, no entendimento de Alberti, é estéril a jornada pela verdade. Chama a atenção ao autor de "Projeto e utopia" o fato dessa narrativa insólita ser contemporânea, na obra de Alberti, aos seus textos mais ligados à arquitetura, como "De Re Aedificatoria". Conclui desse conflito que o rigor geométrico nas obras do arquiteto genovês era um modo de 'dissimular racionalidade', pois a busca por uma verdade, seja pelas preceptivas vitruvianas ou por qualquer outra tática, era afinal inútil, suja e, traidora dos mais nobres ímpetos intelectuais. "A arquitetura assume para si um único trabalho humano: a tarefa de conter a loucura que domina o homem"240.

O caminho que Tafuri tecia nessa ocasião parece claro: nos estudos de Benjamin, aprofundava-se na figura dramática do arquiteto, e como a sua busca filológica era invariavelmente arbitrária. O estudo de Alberti e as contradições entre suas palavras e projetos reforçam essa ausência de parâmetros apriorísticos que supostamente guiaram os humanistas e contra os quais o barroco se lançou: nem nos sonhos a verdade é apreensível.

Tafuri escolheu esse momento dos Intercoenales nos quais a transposição de águas se torna metáfora da constituição do sujeito: para se chegar à verdade inalcançável, é necessário, em um primeiro momento, anular-se como objeto em uma multidão vazia para se ter um direito à memória. Ainda é preciso cruzar um segundo rio, colocar-se como sujeito sobre um objeto - a anciã sobre a qual se monta para cruzar a pocilga. É bem diferente essa imagem das águas daquelas duas que se via nos mares de Veneza: nem a pureza de vícios, nem o fluir que aponta para o eterno.

Em todas essas construções, no entanto, os mares e rios apontam para uma relação com categorias temporais, como o passado, a ação, a memória. Sua presença

\footnotetext{
${ }^{239}$ Idem. p. 59.

${ }^{240}$ Idem, p. 61.
} 
nessas lendas e mitos tem um papel de mediação entre o que está fora do senso comum, resguardar uma temporalidade que ultrapasse idiossincrasias.

Com a "Dignidade do átimo", Tafuri inaugurava um semestre letivo sobre Roma que restaria inconcluso, pois o professor estava já em debilitada condição de saúde. Seu curso anterior, 1992-93, foi dedicado à obra de Alberti. Nele, os rios tenebrosos dos Intercoenales aparecem de novo, repetindo interpretações das aulas dos anos setenta, com conteúdos novos:

Esse rio [o primeiro] é repleto de sombras, fantasmas. Não são fantasmas e sombras estáticas. Quando caem no rio, se tornam crianças, e depois crescem e morrem, sempre fantasmas. O filósofo compreende que as margens do rio são a morte. Pergunta o homem às sombras, e elas respondem: somos centelhas celestes destinadas a virar homens. Almas não ainda encarnadas, e por isso fluem e crescem. Nesse ponto, o filósofo quer saber tudo. As sombras respondem, "pare, homem, de buscar além do que é concedido ao homem."241

As sombras ganham maiores contornos: se em 1978 elas aparecem como simples vultos anônimos cujo significado era a anulação do sujeito, catorze anos depois elas são apresentadas como figuras fantasmáticas, ligadas ao ciclo da vida, e elas próprias advertem ao sonhador acerca dos limites do conhecimento e da racionalidade. O fato das margens representarem a morte e o leito do rio a vida já revela ecos dos temas estudados pelo historiador na sua conferência sobre o átimo. Juventude e velhice são pólos que aparecem na palestra desde a analise do Batistério de Parma, no qual "É a batalha contínua, o ciclo do tempo, do dia e da noite."

${ }^{241}$ TAFURI, Manfredo. Corso di Storia dell'Architettura 2A, Umanesimo e l'architettura: Leon Battista Alberti (1404-1472), lezione: 'Le intercoenales albertiane, il motto 'Quid Tum", 7 de janeiro de 1993, Biblioteca do "Dipartimento di Storia dell'Architettura", IUAV, faixa 04, 3’30". 
O primeiro rio do Sognum, na interpretação mais recente de Tafuri, pode ser analisado junto da Allegoria della prudenza, de Tiziano. Se na Allegoria o adulto é a ação simultânea ao ruminar do passado e a lealdade ao futuro, as sombras também são afetadas pelo ciclo, mas a elas, claro, é excluída a capacidade de ação. A presença delas serve como advertência dos limites da sabedoria contingencial. O ponto comum das duas imagens é aquela de representar um ciclo contínuo do tempo, as quais pareciam estranhas e fascinantes para Tafuri.

Nos catorze anos que separam as aulas sobre os Intercoenales, Tafuri consolidou a última fase de sua carreira e escreveu obras seminais na formulação de seu discurso sobre o tempo: o ensaio definitivo sobre Le Corbusier "Machine et memoir", o seu livro sobre Veneza, no qual consolida a sua posição de cautela acerca da contemporaneidade e os ensaios de "Busca do Renascimento", no qual a medalha de Alberti com o lema Quid tum (para onde?) aparece na capa. Sem mencionar decisões como o apartar-se, nas suas aulas, dos debates de sua própria época, a partir de 1981.

As sombras se tornaram fantasmas. A virtualidade da morte perpassa não só os sonhos dos Intercoenales, mas também as parábolas presentes na "Dignidade do átimo": o instante coincide com o instante da morte. É sedutora a hipótese de que Tafuri, diante de sua condição terminal, desse à conferência traços autobiográficos. Independentemente da verossimilhança que tal suposição possa ter, é impossível concluir sua veracidade. Entretanto, é certo que as categorias de instante, morte e origem estavam em ampla circulação dentro do debate político que marcaram esses catorze anos na Itália, e levam a crer que, para além de imerso em agonias pessoais, Tafuri estava inserido nos dilemas peninsulares.

Os intelectuais italianos sofriam, na época, um crescente afastamento das instâncias executivas dos partidos políticos. O partido comunista italiano, no seu alinhamento com as políticas stalinistas da União Soviética, deixava de dar margem às formulações teóricas em seus quadros, o que moldou uma geração de ativistas preocupada em buscar possibilidades de reinserção nos debates do período. É justamente entre o final dos anos setenta e princípio da década de oitenta que surgem 
correntes de pensamento jurídico-filosófica na Itália, que procuram reposicionar um pragmatismo dentro da academia ${ }^{242}$.

Categorias como "representação" e “decisão" são recolocadas a partir dos ensaios do jurista alemão Carl Schmitt. "O interesse se concentra não somente em Schmitt", escreve sobre o período o sociólogo Francesco Fistetti, "mas igualmente nos politólogos, juristas e intelectuais que foram interrogados acerca da crise da República de Weimar a partir da Constituição de 1919, em particular sobre nós conceituais como constituição e soberania, pluralismo e democracia, legalidade formal e legitimidade. ${ }^{243 "}$

Essa busca italiana por postulações feitas na Alemanha do entreguerras envolveu os círculos de Veneza em torno dos quais orbitava Tafuri e o Instituto. Massimo Cacciari ampara-se em Schmitt para reaproximar trabalho intelectual a processo decisório. "Para Schmitt", escreve Cacciari, “a decisão carente de fundamentos significa que a solução aos problemas [do Estado] se busca autonomizando absolutamente a ratio específica do processo decisório”, concluindo que "O Estado das decisões autônomas é a encarnação extrema do sujeito da metafísica moderna, mas deste sujeito resulta dificilmente decifrável o possível campo de ação, a efetividade."244

O esforço em colocar debates filosóficos na pauta governamental passava por uma ampla discussão acerca dos meandros da democracia representativa e como ela define os meios pelos quais se formula a tomada de decisão, a ação em que transforma a realidade. "A literatura política dos últimos vinte anos", escreveu Patrício Gomez sobre a situação italiana do período, contribuiu decisivamente para renovar o tema da “decisão". (...) Creio que é desse âmbito (alguns nomes, caoticamente: Cacciari, Esposito, Galli, Marramao, Agamben, Vitiello e (...) Bobbio(...)) de onde provêm o

\footnotetext{
${ }^{242}$ Cf. FISTETTI, Francesco. "La crise du marxisme en Italie: 1980 - 2005", In: Cités, v.4, 2007, pp. 159-183 e SASSATELLI, Monica, "Everything changes and nothing changes: Change, culture and identity in contemporary Italian social theory", In: DELANTY, Gerard (org.). Handbook of Contemporary European Social Theory., Londres: Routledge, 2005, pp. 95-107.

${ }^{243}$ FISTETTI, Francesco. "La crise du marxisme en Italie", Op. cit. p. 173.

${ }^{244}$ CACCIARI, Massimo. "Trasformazione dello Stato e progetto politico". Tradução para o espanhol “Transformación del estado y proyecto político". In: Cuadernos políticos", n. 25, 1980, p. 8.
} 
impulso mais eficaz, em termos genéricos, para o necessário agito do imobilismo antidecisionista" $^{245}$.

O processo decisório tem um tempo certo, um momento de ação. O juízo acerca desse momento e os modos pelos quais se chega à tomada de decisão fez com que, no período, a Itália visse ressurgir um debate acerca da temporalidade. Desse contexto que aparecem obras importantes para o estudo do tempo de ação durante a Itália dos anos oitenta, como "Poder e secularização", de Giacomo Marramao, e "Infância e história", de Giorgio Agamben, que sintetizou, em 1978, os termos de um novo debate sobre história: “Toda concepção da história é sempre acompanhada de uma certa experiência do tempo que lhe está implícita, que a condiciona e que é preciso, portanto, trazer à luz.(...) Por conseguinte, a tarefa original de uma autêntica revolução não é jamais simplesmente 'mudar o mundo', mas também e antes de mais nada 'mudar o tempo"'. 246

Para Cacciari, colega próximo de Tafuri em Veneza, a entrada nos temas jurídicos implicou o aprofundamento em categorias do tempo, como resumiu o filósofo Guillermo Bialakowsky, no seu texto sobre a Itália contemporânea:

A politica moderna [para Cacciari] nos leva a uma dupla dúvida: teologia política da representação e teleologia escatológica se implicam mutuamente. (...)

Se considerarmos que a temporalidade mais própria do direito está determinada pelo chrónos e sua linearidade, a justiça, por outro lado, leva o signo de kairós (....). ${ }^{247}$

\footnotetext{
${ }^{245}$ GÓMEZ, Patricio Peñalver. "Decisiones. Schmitt, Heidegger, Barth”. In; Daimon, Revista de Filosofia, n.13, 1996, p. 145.

${ }^{246}$ AGAMBEN, Giorgio. Infanzia e storia: Distruizione dellesperienza e origine della storia. Tradução para português Infância e história: destruição da experiência e origem da história. Belo Horizonte: UFMG, 2008 , p. 111. Agamben escreveu um texto sobre Veneza em que comenta, brevemente, as teses de Tafuri: AGAMBEN, Giorgio. "Dell'utilità e degli incovenienti del vivere fra spettri". Tradução para o português "Da utilidade e dos inconvenientes de viver entre espectros". In: Serrote, n. 6, 2010, pp. 6569.

${ }^{247}$ BIALAKOWSKY, Guillermo. "Tiempo y representación. La crítica impolítica italiana al pensamiento de Carl Schmitt". In: Instantes y azares: Escrituras Nietzscheanas”, n. 9, 2011, p. 297.
} 
A justiça, nessa construção atribuída a Cacciari, possui uma temporalidade atímica. Entretanto, como veremos, tem-se nessa interpretação uma divergência com aquela de Benjamin, cara a Tafuri. O filósofo veneziano dedica parte dos anos oitenta à escrita de uma obra capital sobre temporalidade e origem, nomeada "Do início". Longo escrito, em alguns momentos como ensaio, noutros como diálogo, no qual a possibilidade de um início fundador da filosofia é colocado em ampla discussão crítica. Nele, o kairós, o tempo oportuno, entra em um âmbito do átimo. "O kairós", escreveu Cacciari, "como átimo decisivo, no qual aparece a forma completa (...), é o átimo decisivo de todo momento." 248

O átimo é o campo da decisão, o tempo pelo qual a filosofia reentra na realidade. $\mathrm{O}$ 'início', ou a origem à qual se refere Cacciari, é uma compactação que une os mundos separados, no contexto italiano, das esferas executivas e filosóficas. “Origem do tempo (...) é aquele instante no qual a alma decide temporalizar-se: decisão suprema, pois não vem antes do tempo ou no tempo, mas é o tempo."249 Tempo e ação, segundo o filósofo, são a mesma coisa, quando se trata do processo decisório. $\mathrm{Na}$ sua origem aparecem juntas política e teoria.

Como Tafuri, esse instante vem coroado com uma força mitológica. Cacciari se ampara nos gregos para embasar sua noção atímica, o Aión. Ampara-se numa construção semelhante àquela que Tafuri fez da mitologia de Veneza através de uma concomitância de efemérides (nascimento de cristo, crucificação etc), para mostrar a simultaneidade do instante presente com outros, imemoriais. Cacciari cita o hino de Febo, quando esse, ainda criança (infans), livra-se dos laços e bandas que o prendem e pula do berço, e o hino de Dionísio que canta o deus jovem, à beira-mar, escapando de qualquer amarra lançada a ele, para quem 'nenhum vínculo é indissolúvel'. Após essas imagens, o autor de "Krisis" conclui: "Aión recorda a figura do semper adveniens, que não procede, que não dis-corre (e por isso infans!) que não envelhece - e que portanto os laços dos nomes, os vínculos do onomázein, não o podem capturar." 250

De fato, não se pode negar que as concepções atímicas de Cacciari e Tafuri sejam, nessa época, similares. O filósofo, nesses termos, coloca-se em sintonia com

\footnotetext{
${ }^{248}$ CACCIARI, Massimo. Dellinizio. Milão: Adelphi, 2001, p. 268. A primeira edição é de 1990.

${ }^{249}$ Idem, p. 282.

${ }^{250}$ Idem, p. 283.
} 
autores também caros para a obra de Manfredo Tafuri nos últimos anos de sua vida, como Giacomo Marramao, em seu "Poder e secularização" e "Minima Temporalia". Marramao, por sua vez, é mais direto, enfrenta em seu ensaio as "categorias do tempo" procurando apresentar um itinerário entre as noções temporais desde a aurora da civilização ocidental até o presente.

Também Marramao se ampara em Schmitt e suas colocações decisórias, ainda que seja menos programático na apreensão do que Cacciari. Segundo Marramao, o tempo da modernidade coloca-se como um "futuro passado", no qual uma velocidade acelerada - abastecida pelos fluxos de consumo e outras demandas progressistas acaba por engolir qualquer noção escatológica existente no tempo ocidental. "O Moderno", escreve o autor, "de excitante aventura das margens e dos limites, transforma-se numa progressão geométrica eternamente ameaçada pelo abismo e pela voragem do presente. A época da modernização é a época do definitivo "contrair-se" do hiato entre passado e futuro, do futuro que transcorre com imperceptível rapidez no passado (...)"251.

Essa anulação dos tempos é bem conhecida, resulta no que Benjamin chamava de historicismo e que foi continuamente combatida por muitos autores na filosofia do século XX. Marramao refere-se diretamente à noção de ruptura de tempo escrita por Benjamin nas "Teses sobre a filosofia da história”. O átimo como brilho de salvação, força messiânica através da qual pode-se redimir o passado no presente, romper com o historicismo e com o tempo dos opressores.

Marramao, no entanto, não se satisfaz com essa intuição. "A filosofia da história”, escreve o autor, “(...) só terá - benjaminianamente - um seu radical questionamento quando este for capaz de levar até o fim a 'crítica da estrutura temporal que a sustenta. Isto é, somente quando o imprevisível que irrompe possa ser assumido como elemento dotado de uma lógica própria, irredutível ao logos da sucessão, à disposição assimétrico-hierárquica do tempo: não como 'passado', portanto, mas como persistência, núcleo existencial que o fluxo da temporalidade não consegue dissolver." 252

\footnotetext{
${ }^{251}$ MARRAMAO, Giacomo. Poder e secularização. Op. cit. pp. 118 e ss.

${ }^{252}$ Idem, p. 127.
} 
Não basta um instante imprevisível, é preciso uma persistência de ruptura que não consiga diluir-se no fluxo de tempo. Marramao estabelece um contraponto a tal concepção apropriando-se dos escritos de Heidegger que produzem uma "radical distinção (...) entre a dimensão da Jetztzeit (tempo-agora) - expressão do tempo mundano - e a temporalidade autêntica do átimo (Augenblick)." 253

As teses de Heidegger sobre o tempo foram preferidas na busca dos intelectuais do final dos anos setenta, por melhor servirem às intenções de participação no novo quadro político italiano. Segundo Heidegger, o átimo é rompimento do exílio temporal, ou 'banimento do tempo' em que o ser está inserido. "O instante rompe com o banimento do tempo, pode rompê-lo uma vez que ele mesmo é uma possibilidade própria do tempo. Ele não é, por exemplo, um agora pontual, que só chegamos mesmo a constatar. Ao contrário, ele é, sim, a visualização característica do ser-aí nas três direções de visada que já conhecemos: no presente, futuro e passado." ${ }^{254}$

Marramao parafraseia quase literalmente a crítica de Heidegger à temporalidade hegeliana, conforme desenvolvida nas conclusões de "Ser e tempo". Heidegger descredencia qualquer tentativa de compreensão hegeliana do tempo, na medida em que este “interpreta o tempo orientando-se, primariamente, pelo nivelamento do agora. (...) Se Hegel chama o tempo de 'devir intuicionado', então nele não prevalece o surgir nem o perecer." 255

As teses de temporalidade de Benjamin são reconhecidas nos debates italianos como portadoras de uma nova força acerca de uma temporalidade transformadora. Entretanto, tanto Marramao, como Heidegger e outros, como Agamben, reconhecem em Heidegger um autor mais radical em sua ruptura:

Não foi certamente por acaso que, nas ocasióes em que chegou a conceber o tempo de maneira nova, o pensamento contemporâneo partiu necessariamente de uma crítica ao tempo continuo qualificado. Tal crítica é fundamental tanto nas 'Teses sobre a filosofia da história',

\footnotetext{
${ }^{253}$ Idem, p.128.

${ }^{254}$ HEIDEGGER, Martin. Die Grunbegriffe der Metaphysik. Tradução para o português Os conceitos fundamentais da metafísica". Rio de Janeiro: Gen e Forense, 2011, pp. 198.

${ }^{255}$ HEIDEGGER, Martin. Sein und Zeit, 431. Tradução para o português Ser e tempo. Petrópolis e Bragança Paulista: Editora Vozes e Editora Universitária São Francisco, 2006.
} 
de Benjamin, quanto na análise da temporalidade que Heidegger não conseguiu finalizar em 'Sein und Zeit' [Ser e tempo]." O filósofo analisa brevemente os dois autores, $e$ conclui que "é no pensamento de Heidegger que a concepção do tempo pontual e continuo é submetida a uma crítica radical, na perspectiva de uma repetição-destruição que investe contra a metafísica ocidental em sua totalidade. ${ }^{256}$

Enquanto no brilho benjaminiano o presente salta da contingência para encontrar uma temporalidade atual e eterna, em Heidegger, por outro lado, no instante do presente integra-se passado e futuro a partir da situação que está o ser determinado (ser-aí). Segundo o filósofo, "O instante não é nada além da visualização do caráter de decisão, no qual se abre e se mantém aberta a situação plena de um agir.”257

O ser determinado, através de sua ruptura com o banimento temporal, ganha uma forca de ação. Não à toa, Marramao encerra sua contraposição entre Benjamin e Heidegger através de uma pergunta sobre a força da filosofia diante da contingência presente: “Será então possível que na crise da temporalidade 'soberana', da temporalidade vertical e assimétrica, seja recuperado também um impulso para a filosofia política? Ou: é possível transmitir ao Político uma categoria de decisão que leve em conta diretamente a existência (...)?" 258

Dessas oposições resultava o debate das esquerdas italianas. O tempo integrado do instante, como Heidegger o coloca, resultava mais conveniente para inserir-se numa discussão sobre as possibilidades de transformação do real.

Tal preferência aparece também em Cacciari. Está claro, na obra do autor, o conhecimento e apreensão de noções heideggerianas e, em certas ocasiões, a preterição de postulações benjaminianas. "O que é certo é que, hoje, uma política revolucionária não pode afirmar-se segundo outros métodos: nem como crítica da burocratização, nem como 'dialética geral' de especialismos (que em si seriam coisificados), nem como ideologia dos fins. Tanto menos, é óbvio, como prática neutralizante-mediadora em

\footnotetext{
${ }^{256}$ AGAMBEN, Giorgio. Infanzia e storia, Op. cit. pp. 124 e ss.

${ }^{257}$ HEIDEGGER, Martin. Os conceitos fundamentais da metafísica, Op. cit. p. 196. Grifo de Heidegger.

${ }^{258}$ MARRAMAO, Giacomo. Poder e secularização, Op. cit. p. 129.
} 
messiânica espera que os processos de socialização se transformem em crescimento democrático."259

Em sua busca de uma filosofia decisória, as Teses de Benjamin soaram para Cacciari pouco esperançosas. Se o filósofo, no princípio dos anos setenta considerava o autor de "Rua de mão única" uma referência pelos seus estudos da cidade, dez anos depois tem dele uma visão crítica ${ }^{260}$.

E Tafuri? Está claro como suas considerações sobre o tempo presentes na conferência "A dignidade do átimo" dialogam com toda uma inteligência italiana construída sobre temporalidades de inspiração nos trabalhos de Heidegger e Schmitt. Essa corrente mobilizou o Instituto em Veneza, envolvendo não só Cacciari, mas outros colegas do autor de "A esfera e o labirinto". Entretanto, a noção de tempo de Benjamin permaneceu, para Tafuri, como uma referência importante também em sua obra dos anos oitenta e noventa. Heidegger aparece pontualmente nesse período, como ao escrever sobre Corbusier em "Machine et memoir", nas elaborações sobre técnica ${ }^{261}$. Entretanto, o artigo de Tafuri encerra sugerindo que Corbusier, com sua Main ouverte diante do traçado modernista de Chandigarh, ganha uma "frágil força messiânica”, numa alusão às “Teses” de Benjamin.

Enquanto as esquerdas italianas se organizavam em torno de uma "retomada alemã” que colocava outros autores no debate, Tafuri participava dela de modo

${ }^{259}$ CACCIARI, Massimo. "Transformación del estado y proyecto político", Op. cit. p. 39. Cf. MANDARINI, Matteo. "Beyond Nihilism", Op. cit.

${ }^{260} \mathrm{O}$ processo pelo qual a preferência de Cacciari volta-se a outros autores alemães em detrimento de Benjamin acontece ao longo da década de setenta e ultrapassa o escopo dessa argumentação. Sobre o assunto, é importante um texto de 1975, que o filósofo publica na revista Nuova Corrente, em que trata especificamente das teses de Benjamin expostas no "Origem do drama barroco alemão" e "O autor como produtor". Neste artigo, Cacciari procura mostrar os limites das propostas de Benjamin, sobretudo no que concerne as possibilidades de ação revolucionária a partir de um discurso sobre a técnica: "O encargo teleológico que pesa sob o problema do signo (do a priori material) é de todo ausente em Benjamin. Aqui o discurso utópico é definitivamente cindido daquele teleológico. E somente assim ele fala, sem mais resíduos, do universo dos processos de formalização." Essa ausência de teleologia transformadora é definitiva para que Cacciari conclua que "Por em crise essa estrutura de relações sociais de produção não é 'julgá-lo' ou 'superá-lo', não é o dever das vanguardas, mas desenvolvê-lo até os seus limites, por o desenvolvimento das suas forças produtivas a um nível de socialização e de capacidade inovadora estruturalmente crítica nos confrontos das funções políticas gerais de direção e controle." CACCIARI, Massimo. "Di alcuni motivi in Walter Benjamin - Da Ursprung des deutrschen Trauerspiels a Der Autor als Produzent". In: Nuova corrente, n. 66, 1975, pp. 220 e 243. Grifos de Cacciari.

${ }^{261}$ Nesse sentido, a hipótese defendida por Hélène Lipstadt e Harvey Mendelsohn em "Filosofia, história e autobiografia: Manfredo Tafuri e a 'lição insuperada' de Le Corbusier", sobre a aparição de motivos heidegerianos na obra de Tafuri apontam para uma revisão crítica do historiador que ganha força. No entanto, como demonstra-se a seguir, a relação de Tafuri com os temas de Heidegger sempre foram menos programáticas do que sua postura, mais relacionada ao átimo de Benjamin. 
ambíguo, sem diretamente discorrer sobre o tema em seus artigos, mas também sem descredenciar um pelo outro. Ao escrever sobre o "Projeto histórico", publicado em 1977 e depois revisado como introdução a “A esfera e o labirinto” em 1980, relataria em uma carta ao seu aluno francês Philippe Duboÿ que "ao centro [do artigo] está a releitura - sempre e de novo - de Nietzsche, Freud e Wittgenstein" ${ }^{262}$. Ademais, sua aula sobre o "Drama Barroco" foi ministrada em 1978, quando essa 'guinada decisória' estava já em andamento. Seus trabalhos se ocupam pouco da revisão de temporalidades que estava em curso na península, em Veneza e em seu próprio instituto.

Essa postura reticente é confirmada em um depoimento de Francesco Dal Co, considerando o advento de leituras intensivas de Heidegger no IUAV como uma "separação de caminhos":

[Tafuri] não tinha nenhum interesse por aquilo que tornou-se para outros, como para mim e Cacciari, o centro do trabalho: Heidegger. Tafuri chega [nele] mais tarde, de modo distraido. "Ser e tempo" é um livro em [cuja leitura] nós nos separamos. Tudo aquilo que se referia ao ambiente de Heidegger e da grande cultura tradicionalista alemã, Tafuri os utilizava, mas nunca neles se aprofundou. (...)Toda a ideia de tempo [formulada por] Cacciari e por mim nasce de Schmitt. ${ }^{263}$

Ao final, Dal Co sugere razões pessoais para tal separação, relembrando como, para Tafuri, a simpatia tanto de Heidegger quanto de Schmitt ao regime nazista era visto com maus olhos.

Tafuri, em uma entrevista de 1992, no entanto, alegou ter lido "Ser e tempo" durante seus anos de formação, assim que saiu a primeira tradução desta obra na

\footnotetext{
${ }^{262}$ Correspondência entre Manfredo Tafuri e Philippe Dubö̈, 10 de dezembro de 1977.

${ }^{263}$ Depoimento de Francesco Dal Co.
} 
Itália $^{264}$. É possível que as razões dadas por seu colega Dal Co sejam imprecisas, malgrado seja consenso que, para Tafuri, oriundo de família judaica, foi uma experiência marcante se esconder em subterrâneos durante a guerra, onde contraiu a doença crônica que afinal lhe tolheria a vida.

Independente das razões, o fato é que Tafuri trabalha pouco com uma noção de átimo baseada na de Heidegger. Mesmo em "Machine et memoir", a noção de poíesis e téchne não polemizam com a temporalidade presente no artigo, mais ligadas ao eterno retorno nietzscheano e à memoire involontaire de Proust - além de Benjamin. "Eterno retorno de paz e guerra, mas também intersecção entre infinito passato aquele que brilha no instante que age a memoire involontaire - e a vontade de futuro."265

"A dignidade do átimo", à luz desse contexto, pode ser visto como uma provocação. Nele, Tafuri comenta os debates decisionistas correntes na Itália e no Instituto. O historiador tece noções distintas de instante, ás vezes polemizando e ás vezes se aproximando de seus colegas, mas com uma construção atímica amparada sempre nas documentações venezianas e na história da arte. Cita a teologia de Veneza, os projetos de Corbusier para Argel e Chandigarh e fábulas presentes na literatura cinquecentesca.

Começa com os contos zen e orientalistas para mostrar um tempo eterno, aquele da "dignidade do átimo". A kasbah, a doçura do mel - e até mesmo a iminência da morte dos heróis - têm a mesma expressão similar daquela das águas em que navegava o filósofo dos Intercoenales e o mar Adriático que cerca Veneza: instâncias de mediação entre a temporalidade cotidiana e a imemorial.

No entanto, a apresentação da pintura de Tiziano é claramente uma virada na exposição. O símbolo do Tricipitium, presente na Allegoria della Prudenza e nos desenhos de Colonna são uma evocação de um "agir" que se faz no presente, amalgamado ao passado e futuro como nos termos de Heidegger, Marramao e Cacciari.

\footnotetext{
264 “Eu me lembro, em julho de 1953. Na praça em Corso Trieste, tinha uma livraria muito pequena onde eu vi pela primeira vez a nova edição italiana de Ser e tempo, traduzida por Pietro Chiodi. Comprei o livro e naquele mesmo verão comecei a ler Heidegger." In: "History as project", Op. cit. p. 28.

${ }^{265}$ TAFURI, Manfredo. “Machine et memoir”, Op. cit. pp. 49-50.
} 
Tafuri desdobra esse raciocínio no processo decisório de Veneza durante o Cinquecento, amparando-se nos diários de Marin Sanudo. Mostra uma face de suas pesquisas venezianas que vem de encontro aos debates italianos de sua época. Tafuri analisa as sessões do Senado em que foi deliberado acerca da construção das novas Procuratie, na Praça de São Marcos. Não esconde a sua admiração pelos antigos regentes da cidade, por tornarem a arquitetura um tema de discussão em fóros executivos de política. "Estupendo, para mim, que um Senado decidiu a forma de algo profundamente simbólico para a própria cidade.”

Veneza, no entanto, tem essa noção de tempo peculiar, devedora de seus mitos de fundação, e ali esse processo decisório, no qual o instante é um 'agir', ganha uma face ambígua: Tafuri fala de como a construção das Procuratie, excelente imagem daquela ação coordenada entre passado, presente e futuro, demorou todo o século XVI para ser finalmente concluída. Se a noção do instante tem uma ligação com a capacidade de decidir, Tafuri mostra como nesse processo, o 'leão' que simboliza a ação (e Veneza), é lento na cidade de canais, e justamente dele advém o poder que ela tem diante da contemporaneidade. “(...) O movimento circular que vai avante ao Tricipitium de Tiziano começa a rodar sempre mais lentamente e, ao invés de andar adiante, estanca o passo (...)".

Nesse momento, a conferência alcança um tom antiprogressista. "Não existe progresso ou desenvolvimento (...) sem a mola constante de quem negou o moderno”. Essa fala tem nomeações: "[Os que negam o moderno] podem ser as figuras de um Nietzsche, de um Schopenhauer que negam a síntese hegeliana que é pobre metáfora, pobre consequência da circularidade dos tempos representada por Tiziano.”

Para Tafuri, se existe uma força no átimo de Heidegger dentro das pesquisas italianas, ela se torna mais frágil diante de Veneza. O Tricipitium, menos que um convite a uma ação tradicionalista, remete melhor à compulsória necessidade de prudência no agir tão caro à teologia veneziana.

$\mathrm{O}$ argumento de Tafuri em defesa da preservação da cidade dos canais sustenta-se no fato de que sua cisão com o tempo contemporâneo é estratégica na formulação de uma inteligência que consiga ultrapassar a roda de rupturas que as vanguardas engendram. No entanto, o ponto nodal do artigo não está nessa conclusão, mas no modo como o historiador articula fermentos em voga no seu círculo de 
intelectuais, utiliza-se deles para mostrar que, diante de Veneza, qualquer formulação que coadune átimo e ação são engolidas pelo tempo longo das indecisões e do afastamento da cidade de quaisquer ventos da contingência. Veneza, conforme o autor a estuda nos anos oitenta, não é um estudo de caso, mas sobretudo um arquétipo: a "Dignidade do átimo" procura mostrar que na história da arquitetura, com seus entremeios e decisões cristalizados em edifícios, ruas e praças, todo tempo é o tempo da cidade longínqua, que existe no entremeio dos imemoriais mitos fundacionais e de suas banais problemáticas recentes.

Essa polêmica intelectuais desdobrou-se em efeitos práticos. Em um artigo de 1989, Massimo Cacciari publica na revista de arquitetura Casabella um artigo chamado "Ideia de Veneza". O texto não tem pretensões teóricas maiores do que executivas, lançando os termos de uma discussão programática sobre como se poderia intervir na cidade dos canais.

Sente-se a verve de um crítico de ideologia como é Cacciari, desde sua formação. O filósofo não faz sua advocacia através do apelo dramático: começa seu texto declarando como há um acento negativamente mitológico na intenção de 'salvar Veneza'. Segundo o autor, o ímpeto de se preservar a cidade reflete a sua excepcionalidade. O autor usa o termo "inaturalidade", para designar a existência da cidade como algo improvável, único. "Por muitos séculos", diz o filósofo, "Veneza, as suas classes dirigentes (...) souberam dar forma ao problema de tal inaturalidade."266

Segundo Cacciari, portanto, existe nas decisões das antigas gerações um modo de se atuar em Veneza que deveria nos servir de modelo para atuar. A crise aparece justamente no século XVIII, quando a cidade perde seus modos de 'representar-se', após a perda de sua função comercial e seu status de potência econômica.

Essa argumentação inicial serve para que se construa um texto no qual a história de Veneza seja cúmplice de uma postura interventora no seu tecido. "Veneza é, em si e desde sempre, uma crítica em ato desta banalíssima, atual, demasiadamente atual, oposição entre conservação e novitas." ${ }^{267}$

Em termos acadêmicos, pode-se ver uma interpretação da cidade dos canais de modo análoga àquela construída por Tafuri: sui generis, única na sua forma e que, por

\footnotetext{
${ }^{266}$ CACCIARI, Massimo. "Idea di Venezia”. In: Casabella, maio de 1989, v. 53, p. 42.

${ }^{267}$ Idem, p. 44.
} 
isso, requer uma grande atenção ao seu passado. No entanto, Cacciari parece interessado em fazer girar novamente a roda do Tricipitium: encontrar um átimo de ação na história passada de Veneza, para ser leal com uma suposta tradição de "dar forma a sua inaturalidade”.

O ponto de separação entre as opiniões de Tafuri e Cacciari, no que concerne Veneza, é no entendimento de sua condição de crise a partir do século XVIII. Se para Tafuri a leva de turistas foi um modo de fazer a cidade das máscaras manter sua essência, escondendo-se da contemporaneidade, para Cacciari o congelamento de Veneza e sua transformação em cidade turística é menos uma alternativa de triunfo metafísico do que um problema prático a se resolver. "Nós temos claro que se pode fazer [uma nova agenda para Veneza] não somente participando à vitória da monocultura turístico-comercial que, de fato, representa a negação de toda ideia de cidade (...), [mas] enfrentando com inovação o problema da tutela da imagem de Veneza, a reorganização de seu extraordinário patrimônio museológico, potencializando suas estruturas universitárias e de pesquisa, recuperando seu ambiente lagunar, inventando novas formas de atividades produtivas." 268

Tafuri, em sua conferência sobre o átimo, vai por outro lado defender esse imobilismo de Veneza, não pelo seu valor conservador, de vitrine de tempos antigos para a contemporaneidade, mas pela sua capacidade de manter sua imagem incólume diante da modernidade que "é capaz de salvar as vidas dos homens com refinadíssima cirúrgica, e ao mesmo tempo destruir milhões de homens com técnicas igualmente refinadas, [e] vive do desprezo de si mesma."

A divergência de projetos para Veneza fica mais nítida. Se, tanto para Cacciari como para Tafuri, existe um problema concreto de intervenção na cidade de São Marco, o historiador de arquitetura parece não ver a solução deles através do projeto. Cacciari fala em possibilidades presentes, ataca aquela "Falta de ideias de cidade, pois se tratava de, com coragem, projetar um novo vulto de Veneza, através de obras de grande arquitetura, aquela que em Veneza, foi sistematicamente recusada, de Wright até Le Corbusier e Kahn." ${ }^{269}$

\footnotetext{
${ }^{268}$ Idem, p. 44. Grifos de Cacciari

${ }^{269}$ Idem, p. 49. Grifos de Cacciari.
} 
Tafuri não tem essa visão positiva. Se não se pode subscrever às interpretações de que o autor de "Projeto e utopia" simplesmente abandona os temas contemporâneos por descrença nos arquitetos do presente, também não se pode ignorar que sua interpretação geral da contemporaneidade era crítica. "Não há mais nenhum Senado que decida sobre as honras máximas do máximo espaço veneziano", disse o autor na mesma conferência.

Portanto, era improvável que Tafuri fosse simpático a essa visão intervencionista da cidade, tal como Cacciari a constrói na sua "Ideia de Veneza" e como, nos anos seguintes, conduziu sua gestão como prefeito da cidade. O fio condutor que liga esse texto à gestão do filósofo sobre a Sereníssima é muito direto, basta citar dois exemplos mais marcantes: o primeiro, as intervenções de Oliviero Toscani nos pontos turísticos da cidade, com desentupidores gigantes e outros objetos críticos temporários para afastar os turistas que viriam visitá-la durante só um dia, sem trazer dinheiro significativo aos seus comerciantes. $\mathrm{O}$ segundo, mais duradouro, foi o contrato da quarta ponte sobre o Canal Grande, comissionado ao arquiteto espanhol Santiago Calatrava, para facilitar a chegada de Veneza pelo continente.

A estrutura metálica tem uma solução leve em sistema Virendell, com seus degraus feitos em vidro em uma linguagem contemporânea que a distingue, de imediato, de seu entorno. Do mesmo modo que no Teatro del Mondo, de Aldo Rossi, as fotografias da revista Casabella mostram as peças da ponte passeando por uma Veneza noturna, antes de chegar ao seu ponto de construção.

O diálogo com os casarões do Canal Grande não possui a mesma força de símbolos e linguagens que o projeto de Rossi, e nela fica clara a diferença de projetos para Veneza que existiu entre Cacciari e Tafuri.

O historiador de arquitetura era já falecido quando esses eventos ocorreram, mas é possível imaginar que estaria longe de endossar essa obra de "grande arquitetura”. Mais uma vez, sobressai-se as razões desse descompasso entre os dois colegas, a "separação de caminhos" à qual Dal Co aludiu: distintas concepções de temporalidade e de sua relação com a ação. Cacciari quer reinserir a filosofia no mundo real, utiliza-se de uma concepção de tempo e átimo que lhe deu um acento pragmático que o joga ao plano das intervenções práticas. Tafuri prefere que Veneza seja vista sob a perspectiva de um tempo longo, no qual a contingência foi relegada, 
por sua excessiva contaminação com a modernidade, e assim ela deve ser, no momento presente, mantida.

Com efeito, é somente devido à sua ação como historiador que aparece tal distinção. Se para Cacciari, Dal Co e, fora da ilha, Marramao, Esposito e outros podiam se colocar numa perspectiva de ação instantânea no cenário político italiano, conforme as suas leituras de Schmitt e Heidegger legitimavam, para Tafuri, apreender tal linha de pensamento demandaria uma ampla revisão de toda a sua contribuição. Significaria, em última análise, o fim de sua história.

Cacciari, em "Do início", esforça-se por mostrar o átimo decisório na sua vinculação com a tradição. Dela ele é cumprimento e ruptura. Segundo o autor, "Se a ideia de tradição vai ao seu fundo no instante da decisão, tradição se torna 'história' disso que a interrompe, disso que ela é crise. (...) Não existe tradição senão para tal instante; ela verdadeiramente existe para o seu fim, não é senão a possibilidade da sua morte: 'salva' de tal possibilidade, morreria como tradição. ${ }^{270}$

Entre átimo, ação e tradição, portanto, é necessário uma força que lhes deem coesão e, ao mesmo tempo, que lhes contradigam. Isso tem efeitos particulares no modo como Cacciari escreveu sobre arquitetura: tanto em sua história de Loos, como em artigos sobre Mies Van der Rohe, o autor procura inserir os autores numa vasta rede de debates de seu período, mas procurando colocar como eles indicam sempre uma interação com os debates filosóficos de seu período. Sobre Mies, em 1988:

O trabalho de Mies, mais do que qualquer outro, talvez perdure na forma de nossa imagem urbana e arquitetônica precisamente porque de modo radical se destaca delas, ao mesmo tempo em que mostra esses horizontes na face do trabalbo de seus contemporâneos, nas suas cidades e construções, a qual as pessoas acreditam que ultrapassaram, mas que elas somente se esqueceram. (...) Dasein no meio da crise, ou Dasein que

${ }^{270}$ CACCIARI, Massimo. Dell'inizio, Op. cit. p. 326. Grifos de Cacciari. 
perdura na crise, garantindo seu significado, refletindo sua luz. ${ }^{271}$

A iluminação atribuída ao trabalho de Mies, que nesse artigo de Cacciari é lido como o arquiteto que alcança o "instante pleno" no Pavilhão de Barcelona, é lido na chave de um diálogo entre a vontade de classicismo alemão e uma ruptura que sua espacialidade alcança. A aceitação do Dasein (ser-aí) aparece como ponto máximo de expressão do arquiteto, remontando aos debates do período, mais uma vez, o átimo como Heidegger o entendia.

Tal construção de pensamento seria impensável para Tafuri. Apesar de sempre colocar filósofos, arquitetos e intelectuais numa mesma linha de raciocínio diversas vezes em sua obra, o "instante" de ruptura que aparece nas suas investigações aparecia como algo que vem na contramão da tradição ou, no limite, como uma elaboração arbitrária e independente do período em estudo. Como escreveu Cohen - tendo como referência o artigo de Tafuri "O projeto histórico" - a escrita do historiador italiano é engajada na construção de "ciclos estruturais", que advêm do cotejamento improvável entre períodos, construções e episódios históricos para fazer pulsar a força de suas considerações. Esse cotejamento não se sustenta se o elo que conecta períodos tiver lastro direto com uma determinada tradição ou continuidade literal. Como justificar desse modo o ladeamento entre a capela de San Giussano de Borromini e as collages dadaístas que aparece em "Teorias e história da arquitetura"? Ou tantos outros que aparecem ao longo de seus textos mais ensaísticos, dentre os quais "A dignidade do átimo", que conecta de modo improvável Le Corbusier a Veneza, é somente mais um exemplo?

A temporalidade de Tafuri, o seu "átimo", não passa por uma revisão diante de uma guinada filosófica em curso na Itália da segunda metade dos anos setenta. As razões para esse distanciamento podem até ter um fundo pessoal, como Dal Co sugeriu, mas é certo que uma grande força teórica o levou a sustentar sua posição diante da "separação de caminhos". Simplesmente porque sua noção de tempo endossava um salto do presente para além da contingência, não através de uma

${ }^{271}$ CACCIARI, Massimo. "Mies's classics". In: RES, n.16, 1988, p. 16. 
decisão, mas em uma arbitrária assunção de dilemas concomitantes em categorias nem sempre comuns.

Por isso sua pesquisa, conforme dito no "Projeto histórico", é “infinita”. $\mathrm{Na}$ medida em que a aproximação a um tema pode suscitar novas questões e novos saltos. No entanto, isso não deve ser lido nos termos de uma moral de feição acadêmica, mas como uma postura política, que tem desdobramentos claros nas opiniões de Tafuri sobre Veneza e a contemporaneidade.

Sob esse prisma, resta insustentável a visão de que o historiador romano, através de sua virtuose filológica, tentou impor no campo uma "moral do historiador", como nas interpretações de Andrew Leach que "na pratica do historiador, Tafuri defende pela sua prática, envolve um confronto perpétuo com as suas 'frustrações'. E é exatamente na maneira como Tafuri se encontra com essas frustrações é que fazem seu trabalho tão importante hoje."

Esse suposto confronto perpétuo diz muito pouco sobre as frustrações de Tafuri e menos ainda sobre os efeitos de sua contribuição teórica. Antes, é um ponto de partida para viabilizar os seus raciocínios sobre a contemporaneidade, para que, mergulhando na filologia, pudesse sobressaírem-se atuais considerações.

Essa leitura informou, anos antes dos comentadores se ocuparem do espólio da Tafuri, a oração fúnebre feita por Cacciari durante o velamento do historiador, em 1994. Na ocasião, o filósofo sensivelmente se ampara numa imagem análoga aos rios oníricos presentes no Sognum de Alberti.

"No rio que é Vida", disse Cacciari, "trascorre aqueles que vem batidos de aqui e lá, aqueles que se apegam a odres inflados e vãos, aqueles que nadam desesperados para sobreviver apenas - e outros que resistem, no entanto, outros que se atêm à mesa das bonae artes, outros que põem as mãos na construção de naviculae. E nenhum mais do que estes é caro aos deuses." 273

O rio, a Vida, é chamada como uma metáfora heráclita. "Ninguém é livre da vicissitude que a todos nós envolve, que todos somos." ${ }^{274}$ Cacciari sugere nessa imagem não só uma referência ao modo como seu colega entendia o tempo, mas sobretudo a sua profissão. Nesse sentido, coloca a última obra de Tafuri, "Busca do

\footnotetext{
${ }^{272}$ LEACH, Andrew. Choosing history. Op. cit. p. 298.

${ }^{273}$ CACCIARI, Massimo. "Quid Tum”. In: Manfredo Tafuri: oltre la storia. Op. cit. p. 69.

${ }^{274}$ Idem, p. 69.
} 
Renascimento", como um "Programa de filologia viva de filologia como amor pela palavra viva, pelo clássico como isso que sempre nos interroga e põe em questão, para o clássico como essencial das nossas mesmas inquietudes." 275

A virada de Tafuri ao Renascimento, complexa em suas razões, foi de fato inspirada por um "interesse filológico”? Uma série de eventos e considerações teóricas explicam esse interesse do autor, como a sua busca por uma história da arquitetura feita por protagonistas mais do que por correntes, suas elaborações sobre as cidades contemporâneas e questões consensuais como um certo descrédito pela produção feita durante o seu período etc. No entanto, a filologia foi um instrumento utilizado por Tafuri com afinco desde sua chegada em Veneza, em 1967. Mesmo durante suas obras de abordagem mais geral dos períodos históricos, feitas durante o princípio dos anos sessenta, em Roma, já havia alguns trabalhos nos quais um rigor no trato dos documentos aparecia como matricial, presente, por exemplo, em seu primeiro artigo publicado, "A primeira estrada da Roma moderna"

Sobre esse direcionamento intensivo de suas pesquisas para o Renascimento, que Tafuri passa a engendrar a partir dos anos oitenta, é preciso acrescentar a mudança supracitada no contexto político italiano, que passa a se ocupar de novas questões e traz à tona um debate sobre temporalidades e formas de decisão sobre o real.

Um mês antes de fazer a sua conferência sobre a "Dignidade do átimo", Tafuri fez com seus alunos um seminário para discutir os temas de seu último curso, sobre a obra de Alberti. Nele estão contidas muitas referências ao conteúdo da sua fala, no mês seguinte.

"Os conselhos albertianos sobre como se podem ser arquitetos maus ainda que virtuosos," disse Tafuri, "não são válidos somente pra o '400: porque, repito, vivemos hoje em uma Veneza ainda mais moribunda (...)"277

Durante o seminário, várias vezes o autor de "Busca do Renascimento" faz menção às lições que os textos e projetos de Alberti possuem para os seus alunos. Num curso que focou tanto na tensão entre os textos propositivos e os ensaios críticos

\footnotetext{
${ }^{275}$ Idem, p. 70.

${ }^{276}$ TAFURI, Manfredo. "La prima strada di Roma moderna: via Nazionale". In: Urbanistica, n. 27. 1959, pp. 95-109.

${ }^{277}$ TAFURI, Manfredo. "Seminario". Transcrição de aula de 23 de janeiro de 1993, p. 14. Agradeço ao Luca Scappin por essa referência seminal.
} 
de sua época feitos pelo arquiteto genovês, existia na estratégia pedagógica do autor de "Projeto e utopia" a construção de um diálogo entre a ética de jovens estudantes venezianos e das postulações de Alberti. Os "conselhos" do arquiteto são letra viva, e justamente por isso devem ser estudados.

Não se trata de uma abordagem estranha às práticas de Tafuri como professor, cuja atenção aos humanistas o levava a tentar desenhar como eles, para entender melhor as intenções da forma de seus projetos. Entretanto, Alberti traz em seu trabalho geral não só uma grande noção de arquitetura e projeto decisório, mas também de uma determinada compreensão de temporalidade.

“Também a história é um instrumento moderno", disse Tafuri, “nós queremos lembrar porque somos os seres mais destrutivos jamais nascidos sobre o solo do mundo, portanto temos necessidade de lembrar como excluímos continuamente."278

Essa visão do homem como uma força destrutiva per se, nesse contexto, é um eco da filosofia albertiana. Existe, nos seus trabalhos de caráter crítico, como Momus e Theogenius, uma visão depreciativa da presença do homem diante da natureza. Segundo a historiadora de arte Susanna Gambino, na interpretação de Alberti, "perenemente descontente e insatisfeito, o homem termina por ser um perigo para si próprio e para os outros, na verdade, um inimigo para a natureza." 279

O ceticismo do humanista e de Tafuri apontam numa direção similar: existe um limite nas ambições do homem, tanto na sua capacidade de saber e entender do mundo, quanto de seu poder de transformação do real. Gambino mostra como, no Theogenius, Alberti tece uma imagem de homem que diante de sua fragilidade, escolhe um instrumento errado: o 'progresso violento e destruidor, mas igualmente impotente ${ }^{280}$.

Nos primeiros anos de sua chegada em Veneza Tafuri se esforçou para mostrar o caráter ideológico das vanguardas e sua relação biunívoca com um tipo de progresso ligado ao grande capital industrial e com uma construção precária das cidades. Nos anos seguintes à essa linha de estudos sobre categorias marxistas na arquitetura contemporânea, o historiador constrói uma visão crítica da modernidade nas suas

\footnotetext{
${ }^{278}$ Idem, pp. 1 e ss.

${ }^{279}$ GAMBINO, Susanna. “Alberti lettore di Lucrezio. Motivi lucreziani nel Theogenius". In. Albertiana, n. IV, 2001, p.82.

${ }^{280}$ Idem, p. 84.
} 
postulações mais imemoriais. De acordo com essa interpretação, o Renascimento tem dilemas que o contemporâneo levou ao extremo. Na "Dignidade do átimo", o historiador italiano fala das guerras mundiais e como a técnica vive "do desprezo de si mesma”. Seu mergulho no Renascimento, portanto, é uma busca pela origem.

Entretanto, essa imersão revela sua filiação a uma determinada visão do homem no mundo, que inspirou também Alberti. O tempo do progresso, em contraste com um "tempo da natureza", é um tema do epicurismo romano, sobretudo de Lucrécio.

De rerum natura ficou indisponível para o ocidente por pelo menos quinhentos anos até ser recuperada por Poggio Bracciolini em 1417. Os meandros de sua circulação entre os humanistas é ainda misterioso nos dias de hoje, pela má reputação no período que tinha uma obra de motivos pagãos. No entanto, é certo que Alberti, colega de Bracciolini na cúria papal, teve acesso a essa obra, e teve seus escritos influenciados por ele ${ }^{281}$.

No "Theogenius", a citação direta a obra de Lucrécio é uma discussão sobre a morte das coisas. A discussão acerca do fim da vida remete àquela concepção de tempo lento: "Do nosso primeiro princípio em vida pende o nosso fim em morte. Mas o nosso viver é outro que um morrer-se pouco a pouco?” Alberti responde citando Lucrécio:

\section{Già poi che 'l tempo con sue forze in noi straccò e’ nervi e allassò le membra, claudica el piede e l'ingegno e la lingua persin che manca ogni cosa in un tempo $0^{282}$}

$\mathrm{Na}$ imagem tem-se uma noção de que as coisas vivas lentamente se tornam decadentes. A época em que Tafuri via Veneza como a mais 'moribunda' coincidia com o seu aprofundamento em Alberti e os seus textos sobre rios, fantasmas e morte.

\footnotetext{
281 “Outro acadêmico interessado na voluptas Epicurea foi Leon Battista Alberti (...)" BROWN, Allison, "Lucretius and Epicureans in the Social and Political Context of Renaissance Florence", In: I Tatti Studies in the Italian Renaissance, v.9, 2001, p. 16. "Leitor atento de seus textos, Leon Battista Alberti agrega uma página inédita à história da fortuna de Lucrécio e Epicuro no Renascimento." GAMBINO, “Alberti lettore di Lucrezio”, p. 72.

${ }^{282}$ ALBERTI, Leon Battista. “Theogenius”. In: Progetto Manuzio, 1998, p. 24.
} 
As razões não são acidentais: se o progresso, a modernidade, acelera a transformação da natureza pelo homem, também ela torna mais rápida uma suposta decadência do mundo. O filósofo francês Michel Serres comenta como Lucrécio entendia de modo negativo essa "destinação" humana. "[Lucrécio] descobre a eficácia da flutuação ao acaso, e do desvio do equilíbrio: um tempo excede o outro, é por ele excedido. (...) $\mathrm{O}$ trabalho, a agricultura, a navegação e as artes compensam o efeito da degradação, mas acentuam seu alcance." 283

Veneza, no entanto, recusou a modernidade. Isso que soa crítico para Cacciari é de onde a cidade tira as suas forças, segundo Tafuri. Dessa decadência pode advir o átimo de transformação. Conforme mostrou-se no princípio do capítulo, na obra do historiador romano, o átimo e sua dignidade saltam a partir de imagens de um tempo eterno e sempre longínquo: às vezes, trata-se de uma metáfora orientalista, como a kasbah de Argel ou nos contos zen, mas sobretudo são imagens naturais: os rios nos Intercoenales, o mar Adriático em Veneza, as montanhas do Himalaia em Machine et memoir. Mesmo em obras de sua juventude, como "Projeto e utopia", o Plan Obus não tem seu diálogo somente como o mercado árabe, mas principalmente as "Colinas de Fort L'empereur e a linha costeira"284, dois gigantes naturais.

Tafuri não é literal em sua leitura da natureza que remonta a Lucrécio - um autor que raras vezes é citado em suas obras. No entanto, é presente, nos seus ensaios, a existência de um "outro" não histórico, justamente para que os seus textos, sua filologia, possam alcançar os saltos de raciocínio que unem tempos e permitem sua escrita livre de quaisquer amarras de tradição, escolas e períodos de pesquisa. Mais do que um contraste, essas figuras não históricas são mediação entre os pólos improváveis e são cotejáveis à origem: o homem, na sua angústia de construir, tornou-se eminentemente destrutivo. Como historiador de cidades, Tafuri teve de lidar sempre com esse caráter destrutivo visceral que o urbanismo tem na antecipação da nossa ruína. Se sua obra tem um viés crítico marcado por leituras impetuosas da arquitetura contemporânea nos anos sessenta, essa força é testemunho de sua busca por uma teoria que desse saída desse terrível destino.

\footnotetext{
${ }^{283}$ SERRES, Michel. La Naisance de la physique - dans le texte de Lucrèce. Tradução para o português $O$ nascimento da física no texto de Lucrécio. São Paulo e São Carlos: Editora da Unesp e Editora da Ufscar, 2003 , pp. 280 e ss.

${ }^{284}$ TAFURI, Manfredo. Projecto e utopia, Op. cit. p. 66.
} 
As cidades são uma força que ultrapassam as eras e tempos. São fundadas e refundadas com diferentes desejos, postulações e mitos. No entanto, todas carregam um aspecto de Sísifo, de acentuação da destruição. Por essa razão, Tafuri fez história das cidades, e não arquitetura, pois, na sua construção, existe uma antítese entre essas duas atividades. A história é um instrumento para recordar o que destruímos continuamente.

Única alternativa a essa teleologia distópica, Tafuri se ampara no átimo, o brilho de transformação da história, que salta da linha do tempo. "Walter Benjamin”, disse Tafuri em seu seminário, “o maior pensador de arte desse século escreveu: 'Nós estamos em um estado de emergência contínua." 285

E qual o campo no qual se enfrenta essa emergência? Ao contrário do que o decisionismo pregava no campo intelectual italiano, Tafuri acreditava que o potencial maior estava nas mais decadentes cidades, nos mais esquecidos traços de história. Daí que, para os seus alunos, explique a força do átimo, que restaria misteriosa na conferência:

(...) [Arquitetura] Não faz parte do apocalipse do mundo, antes é somente um pequeno grão, (...) O mundo que vai para isso, para a liberdade, para o progresso etc. Nós não acreditamos mais em nada disso, mas acreditamos que no minúsculo que está aos nossos olhos (...) no minúsculo com em qualquer conto zen, existe um instante onde a redenção da lama, da imundície, é possível. Nós todos juntos, não eu só, podemos ter esses momentos dentro dessa classe. $^{286}$

Não à toa, a "Dignidade do átimo" é uma palestra escolar. Se existe uma descrença na fase final da obra de Tafuri, ela aparece pela construção de uma moldura

\footnotetext{
${ }^{285}$ TAFURI, Manfredo. "Seminario", Op. cit. p. 14.

${ }^{286}$ Idem, p. 14.
} 
teórica pessimista, da modernidade (e da humanidade) como "destrutiva". No entanto, ela permanece atenta a centelha de potencial que se mantém viva. Sua intensiva pesquisa em épocas passadas era um meio de fazer das suas aulas uma Veneza abstrata, um local de reflexão à distância da contingência. Era o seu modo de buscar a "força messiânica" que as novas gerações têm diante de um mundo em catástrofe. 


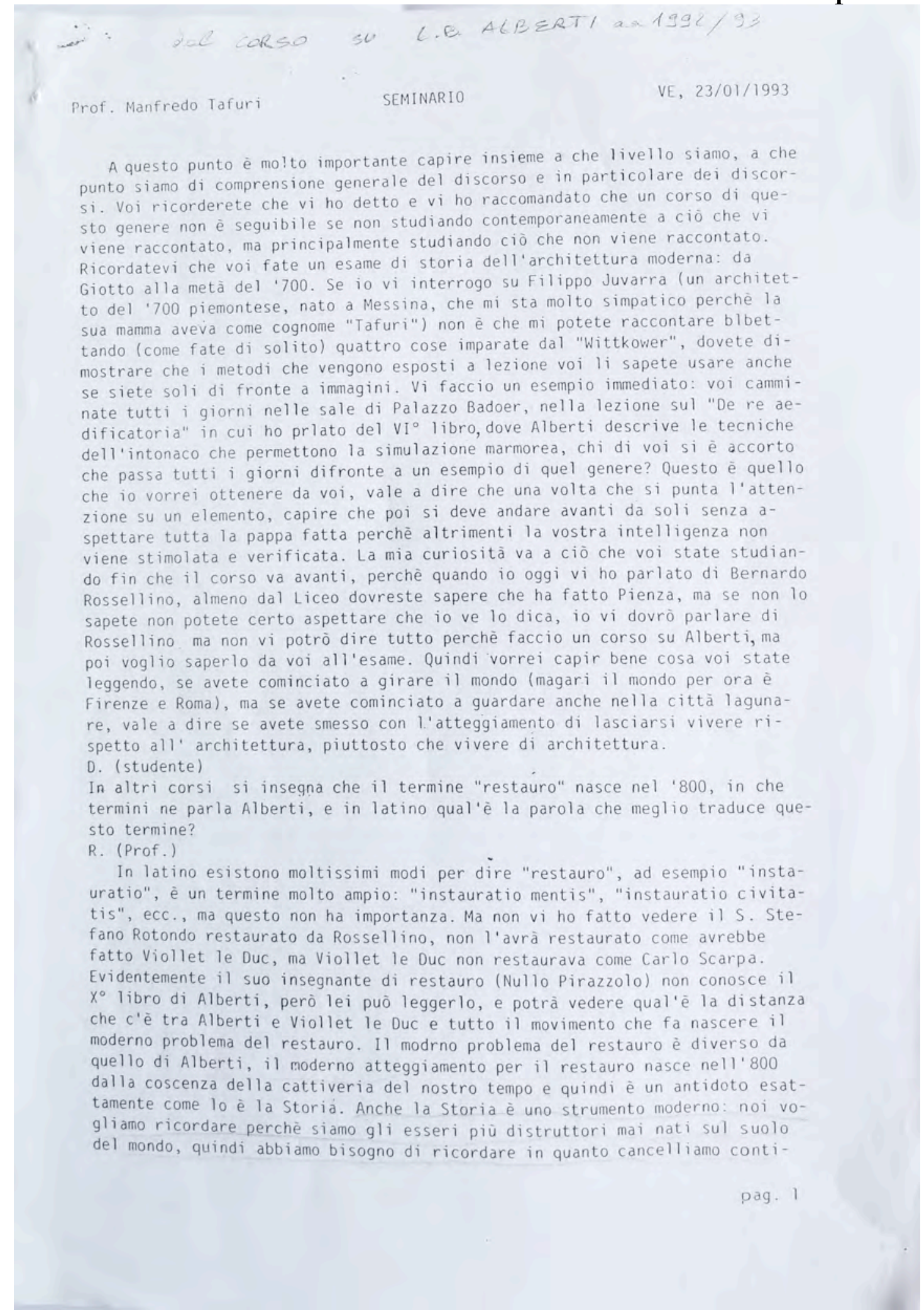

Seminário. Registro de aula de 23/01/1993, transcrito por Luca Scappin. 
nuamente. "Piũ avanza il deserto - scrive il direttore del Louvre - piũ si ingigantisce il museo", cioè il deserto è la vita reale, e piū questa avanza sotto queste forme tanto più il museo si ingigantisce; questa è una metafora, però è chiaro che non bisogna mai dare a una parola un significato univoco. Durante una lezione vi ho mostrato come viene trattato un monumento antico come il S. Donato nel foro di Zara: nel momento in cui gli architetti ignoti del S. Donato debbono fare le fondazioni non si preoccupano affatto se quelle sono antiche e sacre testimonianze, anzi per loro non sono affatto sacre perchè rappresentano gli "dei gentili", perció le utilizzano per le fondazioni del S. Donato. Questa è la distanza che divide questo atteggiamento da Alberti, è il caso di un umanista per il quale restauro significa principalmente "pietas". Noi oggi restauriamo senza pietas, quasi per dovere: per turismo o per riutilizzare l'edificio, questo termine ignobile che è il "riutilizzo" non è pietas.

D Come si legge un libro?

R.

Un libro non esiste di per sè, di un libro bisogna leggere per prima cosa in quale lingua è stato scritto per la prima volta. chi è stato il primo editore, in quale anno è stato scritto (per scrivere un libro ci si impiega 4-5 anni). Quindi è importantissimo l'editore: se oggi l'editore è Laterza il libro è già squalificato, se è dell'Electa è indifferente...; ma importantissimo è l'anno: non si puô dire che un libro è superato, perchè non c'è nulla di superato, ogni libro corrisponde alla sua epoca ma bisogna sapere qual 'è. La "Storia dell'architettura Moderna" di Zevi è un monumento storiografico al1'architettura contemporanea, in quanto uscito nel 1950; quindi un libro o un pezzo di architettura non si presenta a noi puro, ma si presenta carico di tutte le interpretazioni che nel tempo vi sono state date. Una lezione universitaria o una conferenza serve esattamente a mettere a disposizione contemporaneamente 1'interpretazione del testo e questa lunga tradizione che chiamiamo "ermeneutica", di interpretazione del libro, perchè anche se noi non la conosciamo essa vive. Ad esempio, lei ha detto poco fa che "I promessi sposi" è il libro più famoso che ha letto, e che non l'ha molto apprezzato perchè l'ha trovato stantio, ma non avrebbe potuto essere diversamente se non si è immersa negli anni in cui esso è stato scritto: se lo si legge come fosse un libro attuale per forza che appare di una noia mortale.

Ma se invece "I promessi sposi" vengono letti sapendo che prima era stato scritto la "Storia della Colonna infame", sapendo quali sono le condizioni politiche a cui il Manzoni reagisce, sapendo i precedenti a i postumi, e come è stato interpretato, lei, da una lettura di ben altro tipo. Cosi si ca pisce Manzoni rispetto al tempo in cui è vissuto Manzoni e non più come una bellezza astratta. Ma quando io dico che noi, anche rispetto a un testo storico-architettonico teniamo sempre conto (anche se non vogliamo) delle interpretazioni che si sono accumulate nel tempo, questo lo possiamo dimostrare molto facilmente: ad esempio nessuno di voi distruggerebbe il colosseo per il traffico, molti di voi lo trovano bellissimo (anche se qualcuno potrebbe dimostrare che non è proprio il capolavoro dell'età flavia), però nel dire che è bellissimo si rende secoli e secoli di ammirazione per il colosseo, ma anche secoli di disprezzo. Ad esempio Papa Sisto $v^{\circ}$, un papa molto energico, molto decisionista, ma anche molto ignorante voleva trasformare il colosseo 
in una filanda; un altro tentativo verrà compiuto nel '700 da Carlo Fontana sempre per ordine del Pontefice, il quale cercherã di trasformarlo in un grande tempio cristiano. Ma la cosa interessante è che sia il tentativo di Sisto $v^{\circ}$ ( 1585 circa) di degradare il Colosseo ad un'opera industriale (probabilmente avrà pensato che dal momento che Roma sta ormai per crepare di fame chi se ne importa di questi archi...), sia il tentativo dell'altro pontefice nel ' 700 (Roma ormai è già morta di fame, quindi praticamente avrebbe potuto dire: "facciamo vedere che siamo ancora qualcuno nel mondo, trasformiamo quest'opera enorme in una chiesa"), rimangono tentativi che non si sono concretizzati. La cosa interessante riguarda il perchè il monumento è resistito: perchè la forza, non che proviene dal Colosseo, ma dal giudizio sul Colosseo accumulatasi per secoli e secoli ha impedito la trasformazione eccessiva del colosseo stes so. Cosa che non è accaduta per i monumenti di altra forza: nel foro romano al posto del tempio di "Antonino e Faustina" sorge una chiesa del primo " 600 , quel monumento non ha reagito. Dunque la forza dell'ermeneutica, vale a dire della tradizione critica o ammirativa accumulatasi sul monumento puo essere più o meno forte e non ha relazioni con il monumento, è il nostro giudizio soggettivo.

Quello che è importante rispetto alla sua domanda è che leggere un libro significa conoscere bene dove esso gravita, a chi esso è diretto e quindi non si può fare a meno di ricorrere alle interpretazioni date al libro. Per esempio in un testo antico come il "Momus" c'è un lato che banalmente si chiama "cinico", bisogna dunque chiedersi se in quell'ambiente, nella Corte laddove Alberti stava scrivendo non c'era per caso un favore verso quell'antica letteratura "cinica", perchè l'interpretazione contraria a quella di un certo schieramento culturale (Garin, Marolda, ecc.) sostiene che il "Momus" è uno scherzo letterario e che non ha molta importanza. Ultimamente per smorzare un po' la drammaticità albertiana è stato notato che un amico di Alberti, Poggio Bracciolini, scrive un "De cinicus" perchè nell'ambiente letterario di Niccoló vo esisteva effettivamente un interesse per quel Luciano di Samosata letterario "cinico", proprio puramente letterario come riminiscenza di quel lato della letteratura Antica. Questi elementi se io ve li dessi, insieme ad altri elementi, potrebbero alla fine risultare dannosi: non capireste nulla perchè sommersi di informazioni. Infatti come ho sempre detto, lo storico è colui che stabilisce cosa dimentica, non quello che ha maggiore capacità di ricordare, piū cose ricorda uno storico e meno puõ fare storia.

Dunque un'esercitazione divertente da fare a casa sarebbe quella di prendere un testo e cominciare a leggere tutto quello che si è detto di quel testo, perchè quello che si è detto di quel testo entra nella mentalità comune: se Manzoni non fosse stato iper riverito dalla critica cattolica del XIX ${ }^{\circ}$ secolo non sarebbe mai stato imposto dal Ministero della Pubblica Istruzione come autore fondamentale.

Altro esempio l'architettura di Francesco Borromini, quando la sua opera si presenta al pubblico è immediatamente criticata da Bernini (il quale lo va a dire addirittura in Francia per avere una cassa di risonanza maggiore), immediatamente dopo c'è tutta una corrente che vede in Borromini "scarabattolerie di fantastico" (Francesco Milizia), dopodichẽ viene preso per pazzo. $\mathrm{Nel} 1930$ un grande storico come Hans Sedlmayr (il quale aveva un piccolo difetto: era nazista; la cultura spesso è una cosa molto complicata...) scrive 
un libro: "Die architektur Borrominis" (non tradotto in italiano), con il quacercando di dimostrare che il tipo mentale di Borromini é la schizofrenia acuta; dopodichẽ l'opera di Brauer-Wittkower: "Die zeichnungen des Gianlorenzo Bernini" (1931); poi un grosso revival di studi borrominiani comincia: l'"Associazione dei cultori romani di architettura" pubblica dei volumi intitolati "Architettura minore a Roma" nei quali sono inserite foto di opere borrominiane; poi esce la fondamentale opera di Eberhard Hempel (con molti errori, ma sono errori che sappiamo noi oggi, alla data della pubblicazione del libro la cosa era geniale), il quale fonda una scuola di studi borrominiani portati avanti oggi dal massimo borrominista che è Joseph Connors. Dunque sia per coloro che sono vissuti nel 1700 , ma anche per quelli del primo 900 le opere di Borromini avrebbero potuto benissimo es. sere distrutte. In questo secolo sono state distrutte coscentemente, non dico come la torre di Pavia che ẽ caduta giũ per incuria (adesso sta per cadere il $\mathrm{S}$. Michele in Ciel d'Oro), sono state volutamente distrutte molte opere (S. Eligio dei Sellai opera del '700 .......... l'Ospedale di S. Giovanni Fiorentino ........), vale a dire che ci sono delle opere che non resistorio perchè 1 . tradizione ermeneutica è debole, ecco dunque la responsabilità dello storico. La responsabilità di uno storico è quella di creare tradizione interpretativa, per opere o cicli, perchè nel caso di Borromini non soltanto la sua persona, ma tutta la sua scuola veniva investita di male parole. Quindi nella storia non abbiamo mai nè vincitori nè vinti, è lo storico che lo stbilisce giorno per giorno chi puõ essere il vincitore e chi il vinto, e chi vince e chi perde in quel momento dipende dal pubblico: lo storico puõ dire quello che vuole, ma bisogna vedere come reagisce il pubblico.

Il "De pictura" è particolarmente difficile da leggere non per quel che dice che è semplicissimo, ma perchẽ Alberti si riferisce con molta precisione alla pittura del '200 e del ' 300 cosa che noi non possiamo conoscere oggi altrettanto bene e specificatamente, quindi ogni parola che dice si riferisce a qualcosa di ben preciso che noi non sappiamo, qui è la difficoltà.

Alcune operazioni potete farvele da voi prendendo un testo, ma conoscendo molto bene per chi è stato scritto, cosa sta succedendo mentre quello scrive, cosa succede a lui personalmente e che cosa succede nella società, se quello che succede a lui personalmente corrisponde a quello che succede nella scietà e che cosa ne è stato detto nel tempo. Il libro dunque, o il testo artistico-architettonico si presenta a noi carico di-tutto questo (anche se noi non 10 sappiamo) e di tutto questo ne assumiamo l'eredità: noi oggi non riusciremmo a dire quanto è brutto $P$. della Francesca, ma fra tre 3 secoli forse si lgià oggi qualche eminente critico ci mette sull'avviso...., non lo dico io, ma 10 dice qualcuno che va rispettato). Una lettura naif di un testo ò impossibile specie se su quel testo si è stratificato tutto quello che è stato pubblicato. D.

Quali sono le condizioni della fabbrica di S. Maria del Fiore all'arrivo di Brunelleschi?

R.

Il progetto di Arnolfo di Cambio era già stato continuato da Francesco Talenti, quelle fabbriche hanno si dei protagonisti ma ci sono una quantità di personaggi incredibile. Non è un caso che io abbia glissato sulla cupola, perchè la cupola è principalmente un fatto tecnico, in quanto era tutto predeter- 
minato: larghezza, altezza, curvatura. Specialmente in questi ultimi $5-6$ anni sempio un'interas complicatissimi sulla cupola del Brunelleschi, per e-

lo di Martin Wackernagel dimostra in 12 a vato alla quarta poi ho smesso) che lib pano arriWackernagel (che è proprio dei periodi di transizionel dice periodo di cui non so, vale a dire sulle relazioni Ghiberti-Bunelleschi (e fa tutto quello che è stato detico

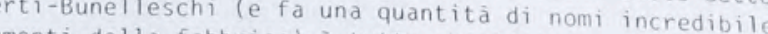
fatto vero secondocumenti della fabbrica) è tutto sbagliato perchè non è af non abbiano avuto importanza tri personaggi che hanno lavorato sulla fabbrica complicazione costruttive della cupola, è una finale, che è certo è che quello che appare all'Alberti è un miracolo tecnica. Prbabilmente perõ è un miracolo nel senso di un pasticcio tecnologico o meglio di un grosso arrischio tecnologico, cioè io credo che con crollata e credo che le tecniche con cui è stata fatta non erano state pensate tutte prima dell'esecuzione. Se la cupola la si vede da dentro ci appare un caos: ponti che si interrompono, catene lignee messe non si sa perchè (alcune spezzate), alcuni pezzi di ferro sbattuti li perchè non erano sicuri di cosa sarebbe successo, il sesto acuto ma poi il giro della muratura a spina pesce che segue una pianta come fosse circolare. Io credo che li ci sia stato il tentativo si di meravigliare Firenze con una tecnica assolutamente inedita, ma credo ci sia anche stato un tentativo letterale proprio per esaltare l'ingegno fiorentino perchè Brunelle schi è Firenze, di rendere perfettamente limpido e razionale ciō che è stato un processo faticosissimo con moltissimi cambiamenti.

Non ho studiato in maniera sistematica questo tena perchè sul piano architettonico nón mi dice nulla, andava fatta cosi e basta, era solo un fatto di tecnica. Il lanternino invece pone problemi di architettura, ma quelle sulla cupola sono quattro balle controcorrente, c'era già nei primi progetti, è una cupola a sesto acuto (ma questo non ci dice nulla: gotico o non gotico). Certo, Brunelleschi è un uomo del suo tempo quiindi ha dietro di sè una serie di preferenze, non si vergogna ad allungare in maniera paradossale una parasta, ma però poi dopo pochi anni se ne vergogna e corregge il tiro.

Questi sono fatti che non è che poi dobbiamo inquadrarli in queste categorie che lascerei tranquillamente all'ingenuita della cultura anglosassone: il gुotico, il rinascimento, ecc.. Quando voi venite agli esami e io vi chiedo ad esempio chi è Carlo Rainaldi, voi generalmente dite: "appartiene all 'età ...", allora io interrompo e chiedo a voi a chi appartenete, perchè se voi lo sapete lo sapeva anche lui e se voi non lo sapeté non ìo sapeva neanche lui. D. $R$.

Qual'è la differenza tra un fatto tecnico e un fatto architettonico?

Non vi ho detto che una volta imoostata la chiesa di S. Maria del Fiore con una cupola che doveva avere quelle dimensioni, perchẽ si era arrivati al tamburo prima di Brunelleschi, Brunelleschi non aveva altro compito che alzare una cupola con 8 vele e costoloni che raggiungesse i 328 metri? Questo era tutto predeterminato; quindi è solo come farla che può meravigliare il mondo non che si fa. Ma provateci voi: se vi si da un'ottagono, il punto dove dovete 
arrivare per fare il lanternino e addirittura il sesto della cupola ditemi voi dov'è l'architetto: l'architetto è colui che riuscirà a rendere questo tema
obbligato una meraviglia tecnica.

La cupola di S. Ivo alla Sapienza non ha nessuna determinazione ed è tutta autoportante, per forma è genialissima e in questa genialità c'è una riccezza spaziale incredibile, c'è una fusione di sapienza tecnica e di sapienza spaziale notevolissima; non è $i l$ caso di S. Maria del Fiore, ma questo non ci deve sconvolgere.

D.

Vorrei avere delle spiegazioni di carattere tecnico sulle cupole di Guarini viste nelle lezoni precedenti e...

R.

Molto spesso come voi avete capito, inserisco a lezione imagini che vi facciano venire le curiosità che a lei sono venute, nel senso che cerco di inserire: antico, romanico, gotico, baroccó, ecc.; cerco di mettere tutto quello che posso proprio perchè voi capiate che la storia dell'architettura non è Alberti, il quale non è nient'altro che un granellino di sabbia in un'immensa distesa di deserto. Quindi la sua domanda mi piace però non le posso rispondere, la sua domanda mi piace nel senso che a lei fortunatamente le è venuta curiosità per un'architettura non 0ccidentale: araba, mozarabica; inoltre ha colto e di questo pure sono felice, una fuggevole frase in cui io affermavo che Guarini ne prende visione e interesse. Tutto questo però è degno di due corsi universitari: uno che spieghi tutta la genesi e il perchè dell'architettura non 0ccidentale (araba o islamica); l'altra del come mai un filosofo-matematico di un'ordine religioso "teatino", alla fine del '600 passando in Spagna per andare in Portogallo (Lisbona) a costruire una chiesa (che purtroppo viene distrutta dal terremoto del 1750), viene evidentemente colpito da qualcosa che nell'architettura 0ccidentale non era mai apparso (non è propri vero, ma in prima istanza è così), tanto da usarlo nelle sue architetture in Boemia per esempio creando li una vasta diffusione.

Ma una volta data questa enunciazione se volete saperne di piũ c'è bisogno delle centinaia e centinaia di immagini, di libri, di studi da fare, che voi potete fare su qualche manuale se ne avete curiosità. Per chi fosse interessato a Guarino Guarini puõ prendere il volume di Harold Alan Meek tradotto dalla Electa (che ẽ un libro molto mediocre, non esistono dei lavori contemporanei di alto spessore su Guarini), che vi fa vedere più o meno che cos'è questa stranissima architettura guariniana, che da un lato segue il dettato di Borromini, e dall'altro crea delle premesse perchè in Europa si stabilisca una specie di lingua barocca universale nella prima metà inoltrata del '700. Una volta detto questo non posso dire molto di più, perchè altrimenti facciamo altre storie.

Per quanto riguarda l'aspetto tecnico delle cupole del S. Lorenzo a Torino, basta una volta entrati guardarle da sotto e confrontarle con le cupole strutturali arabe per capire che il rapporto è fortissimo dal punto di vista figurativo (ma mentre gli arabi avevano secoli e secoli di esperienza, Guarini le vede in Spagna e deve trasformare il tutto in un'esperienza di 10-15 anni di vita). Bisogna poi entrare dentro la struttura delle due cupole guariniane del S. Lorenzo per capire il pastiche che esiste di elementi a tirante, dove appare chiaramente che l'architetto non era affatto sicuro (è un po' come la cupola del Brunelleschi, ma nella cupola del Brunelleschi è tutto molto piũ raz- 
zionalizzato). Nelle cupole del S. Lorenzo l'architetto fa di tut to per far credere che quella struttura è una struttura in cui la luce fora le cupole, che diventano quasi diafane, cioè puri elementi strutturali; non è vero niente perchè dentro $c^{\prime}$ è una struttura porosa pienadi tiranti di legno, pezzi di ferro, ecc.: una grande architettura con una tecnologia non corrisnondente.

Nella cupola Antonelliana è tutto il contrario, è tutta la razionalità positivistica che si adopera a Torino in alternativa all'architettura del ferro, della ghisa, ecc., la quale mostra che una massima sapienza dell'architettura tradizionale puó portare ad una meraviglia tecnologica come la mole Antonelli. ana, o come dello stesso Antonelli il tempio di S. Gaudenzio a Novara.

Peró tutto questo va benissimo, ma io ho l'impressione che voi usiate male il tempo dei seminari, io ho questa impressione fortissima che voi vogliate evitare discussioni: sono sempre domande, non date mai risposte provvisorie e deviate sempre sugli affluenti, mai sull'obbiettivo centrale di ciô che vi racconto. A me risulta che durante le esercitazioni avete fatto domande a cui non sono state date risposte rimandandole ai seminari, si può sapere quali sono?

\section{(silenzio)}

Dunque, o voi imparate a lavorare durante i seminari oppure io utilizzo queste due ore per riposarmi che ne ho molto bisogno, perchè i seminari dipendono da voi, non dalle mie risposte: i seminari veri sono quando uno risponde al dubbio di un altro. Se voi non avete voglia di fare un lavoro di questo genere perdete moltissimo,' perchè perdete la capacità di parlare tra di voi, la capacità di dichiarare le proprie défaillance che oggi sono tollerate, ma tra pochi mesi non sono piũ tollerate con la massima spietatezza.

Non capisco con quale intelligenza voi rendiate questi seminari cosi noiosi: perchè lo ripeto, nei seminari una domanda come quella su Guarini è una domanda da primo della classe, e io gli ho dato una risposta dicendo: "bravo, vattelo a studiare"! Dove sono qui le immagini, ma non solo dov'è qui la cultura per parlare dell'architettura araba, mozarabica, ecc.; e poi di Guarini: prima bisogna sapere tutto il '600 e poi tutto il '700. Quindi ha fatto bene a capire che qui esiste un problema, ma come mai viene estratto un particolare quando ciô che si sta presentando è la più grande rivoluzione mentale che nel mondo 0ccidentale è stata compiuta? Io ho sempre detto che le domande che amo sono quelle delle persone che non hanno capjito niente.

Quando io dico: "Giovanni Pico della Mirandola", mi fate il sacrosanto piacere di dirmi chi è, che cosa ha detto e qual'è la sua importanza storica?

\section{(silenzio)}

Io ho chiesto che alzi la mano chi conosce il pensiero, a sommi livelli, a livello di liceo (1'avete fatto il liceo o no?) di Pico della Mirandola e di Lorenzo Valla perche io ve li ho citati, giustamente in un corso di storia dell'architettura; come riferimenti; perchè se non li avete capiti e non li conoscete metà di quello che vi ho detto è oscuro.

In questi seminari noi non possiamo sanare le vostre lacune, ma possiamo cominciare a dirvi: "prendi di nuovo il testo del Lamanna (vol. I $1^{\circ}$ ), è un $1 i$ bro che fa schifo, però ti dice chi è Lorenzo Valla e che cos'è il sincretismo religioso, che cos'è la magia, che cos'è la superstizione, che cos'è l'alchi- 

mia, perchè non va bene applicarlo alla storia dell'arte e all'architettura
specie nel caso albertiano.

Quindi ho l'impressione che mi state fa facendo perdere tempo, perdendone peró voi; tanto si è capito che nessuno di voi sa chi è Pico della Mirandola ne Lorenzo Valla. Però badate a una cosa che vi ho detto fin dall'inizio, se voj non mi seguite studiando le cose per cui siete degni di essere dentro all'uni-
versita, 330 siete e 330 non passano al $3^{\circ}$ anno.

Quando parlo dell'alta etica albertiana significa che il sottoscritto se l'è chè ogni architetto puô fare un soldo bucato perche ogni architetto puô fare un male terribile all'umanità, e preferisco che non ce ne siano più pittosto che ci siano architetti sbagliati. chitetti sbagliati si chiamano Larini e tutti quei socialisti che stanno in carcere. Quindi nel momento in cui si parla del problema " $x$ " voi dovete essere in grado di poterlo affrontare; se $i$ vostri licei sono stati cosi schifosi da non darvi neanche le basi per capire cos'è il neo-platonismo allora rinunciate immediatamente all'università, perchè non siete neanche geometri di provincia. Se volete stare dentro l'università vi fate da soli quell'argomento, e se vovolete essere aiutati in questo non fate $i$ saccentini con domande raffinate ma chiedetemi le cretinerie che voi non sapete, cosi cominciamo a vedere cosa ac cidenti sapete e cosa non sapete; inoltre vorrei anche sapere cosa leggete la sera prima di andare a letto: se solo "Topolino", oppure anche il "Munford", "Zevi", "Krautheimer", "Wittkower", perchè se non fate questo voi non siete studenti di architettura.

Voi penserete che sono arrabbiato, non sono arrabbiato per niente, cerco solo. di farvi entrare in testa che lo Stato italiano (che è quella merda che è), ha condizionato la vostra generazione in un modo talmente profondo che se volete uscirne (vale a dire dallo stato: per cui noi dobbiamo pagare come contribuenti i furti di 20,30, 40 anni di mala amministrazione con la totele omertà dell'intera classe politica, questa è la situazione in cui siamo), se voi volete essere una generazione di giovani che non sia giã scenescente alla vostra età, dovete fare uno sforzo su voi stessi estremamente violento per dimenticarvi tutto: il costume decadente e schifoso che vi è stato solamente comunicato (non insegnato) leggendo i giornali, e comunque del costume in generale del lassismo italiano e in parte anche europeo.

Non credo che oggi si possa fare mestiere intellettuale se non si sa con grande chiarezza che siamo sull'orlo del baratro: non in Italia, è la modernità che è sull'orlo del baratro, e non abbiamo vie d'uscita. Abbiamo però i mezzi della comprensione razionale, ma se voi non vi fate le basi di questa costruzione razionale voi siete e sarete: 1'80\% di voi disoccupati comunque, il resto corrotti (perchè per trovare un lavoro, specialmente in architettura ci vuole ormai un animo fortissimo per non essere corrotti), o degli schiavi. Questo è il vostro destino, so che nessuno ve lo racconta ma questo è il vostro destino; quindi l'unico strumento che voi avete in mano è quello di diventare eroi intellettuali. Ma per essere tali tutta la cultura europea, lasciamo perdere quella extraeuropea, ma tutta la cultura europea deve essere la vostra arma altrimenti siete nemici, perchẽ altrimenti siete con tutti $i$ politici corrotti che ancora non sono entrati nelle patrie galere e quelli che gia ci sono entrati, quindi siete miei nemici.

D:

Ma lei ha detto che soltanto il mondo intellettuale è sull'orlo del baratro? 
R.

Io non ho detto "il mondo intellettuale", ho detto che "il mondo" è sull'orlo del baratro. Perchè non va in Bosnia o in Somalia, pensa che il mondo sia Pordenone? Perché non andate a Reggio Calabria e ci rimanete, sarebbe un grandis simo esempio quello di uscire da questo schifosissimo alveo-assistenziale che è questa facoltà di Venezia, la quale penso sia totalmente diseducatrice perchẻ vi considera dei bambocci e voi ci state felici.

D.

Lei non pensa che non solo il centro storico di Venezia, ma anche altre località periferiche come Zelarino potrebbero essere considerate come una "calda madre"?

R.

Io sono molto d'accordo con lei, quando sono venuto qui a Venezia mi sono trovato molto bene perchè da Venezia si poteva vedere il mondo (cioè si tratta di un luogo fuori dal mondo da cui si puõ esplorare le cose piũ complesse), ma era una Venezia molto diversa da quella di adesso, anche il pubblico universitario era diverso, proprio i giovani erano totalmente diversi: non che fossero migliori intendiamoci, erano semplicemente diversi. Poi ho cominciato a capire che Venezia uccide le capacitã di comprensione dell'architettura, proprio perchẻ a Venezia architettura non ce nè: cioè nel momento in cui avremo capito Alberti fino in fondo vi si chiederà di constatare la miseria dell'architettura veneziana, il che non significa che la storia di Venezia non sia una grande storia, perchè mica coincidono la grandezza dell'architettura e la grandezza della storia.

Una cosa poi che ho sperimentato proprio in questi ultimi anni: nel 1971-72 io davo delle tesi ad esempio su "New York", su alcuni importanti fenomeni che capitavano a New York perchè avevo fatto un corso triennale sull'architettura dal '700 al '900; allora gli studenti andavano a New York e tornavano carichi di documenti, e non avevano assolutamente nessuna meraviglia che se loro volevano studiare New York dovessero andare a New York. Un ex docente di questa facoltà (che é stato un mio allievo, adesso insegna a Ferrara) che si chiama Sergio Polano: veniva da Livorno e studiava a Firenze, gli faceva schifo quella facoltã cosi venne a Venezia, chese a me di-voler studiare "Theo van Doesburg", ma io gli dissi che avrebbe dovuto imparare l'olandese: si presento dopo tre anni dicendo di conoscere l'olandese, la sua tesi di laurea è uscita a fine anni '70. Quando io dico a voi studenti di $2^{\circ}$ anno: "Theo van Doesburg", e non sapete chi è questo personaggio centrale nelle vicende dell "'avanguardia" anche architettonica degli anni 20-30, dovreste preoccuparvi moltissimo. Capite qual'è il problema? Giusto Zelarino, ma il mondo è un'altra cosa e dovreste conoscerlo. Andate a Reggio Calabria, andate a Palermo: li rischiate la vita, dopodichè capite cos'è un mestiere vero. I magistrati che si battono li hanno fatto si l'università, ma evidentemente non l'hanno fatta in maniera troppo passiva se hanno assorbito un'etica cosi alta da mettere a disposizione la loro vita per tutti.

Badate che anche per voi c'è bisogno di un'etica altissima, mica a caso vi faccio Alberti, mica perchè mi è venuto in mente la notte: nel momento più basso (perchè credo che la melma italiana abbia ormai raggiunto livelli stratosferici), che almeno in un'aula risuoni il pensiero albertiano é un atto di violenta protesta. Voi dovreste capire perō che tutto il sapere di quest'uomo, il quale non è un exemplun per nessuno come nessun uomo è un esempio per gli altri, ma che tutta quell'enorme quantitã di sapere necessario per poter vivere solo onestamente oggi voi non potete non averlo ( non potete farvi condi- 
zionare dai "Nulli Pirazzoli"). Voi dovete capire che esiste una cultura che non si assorbe solo dentro l'università, perchè i vostri docenti sono in buona parte architetti, cioè piccole imprese. Voi dovete capire che c'è una frattur violenta tra le materie che hanno una tradizione secolare dietro di sè attur tre che non sono discipline ma delle arti, che quindi sono difficilissime da insegnare. Un professore di composizione va capito, bisogna anche avere un di comprensione per lui perchẽ non ha niente da insegnare, non ha nessun meto do consolidato: la sua è un'arte, e dovrebbe quindi portarvi a bottega come si è sempre fatto in 20 secoli di storia. Si è inventato una facoltà universitaria assurda, dove c'è una disciplina come la storia che ha dietro di sè da Erodoto in poi, quindi una quantità di tradizioni disciplinari tale per cui consolidatissima; le matematiche: da Euclide a Pitagora in poi; e poi altre che invece raccontano delle favole. Voi non avete ancora la capacità, forse il giudizio di capire che quelle favole hanno anch'esse un significato, e che non vanno confrontate con le materie scentifiche. La storia è una scienza in quanto la scienza poggia sull'incertezza: la scienza è una cosa mutabile e vale tanto in quanto sbaglia, non tanto in quanto ci azzecca, o meglio quando sà di sbagliare, quindi disponibile a mutare continuamente: voi non avete idea di quante date di cui all'inizio dell'anno eravamo sicuri le attribuzioni siano poi cambiate alla fine dell'anno.

Gi $i$ architetti invece fanno dei pensierini, non molto alti perchè siamo in una situazione di crisi generale, e cercano di trasmettere a voi degli strumenti perchè possiate disegnare delle cose.

Quindi in un certo senso le guide all'università andrebbero fatte in maniera totalmente diversa, è inutile dirvi quante ore di qua e quante ore di là e cosa farà quel corso; bisognerebbe dirvi: "Questo corso racconta favole funzionali a..., affinchè voi non abbiate troppa paura a mettere mano a un foglio di carta per disegnarci sopra. Quest'altro corso è un corso che ha dietro di sè 20 secoli di sperimentazione e il personaggio che fa questi corsi studia ventiqattro ore al giorno, l'altro disegna ventiquattro ore al giorno".

Quindi c'è una grossa differenza, ma non è uno vale di piū e l'altro vale di meno, c'è un conflitto: questo è forse quello che non avete capito, che c'è un conflitto tra la storia e la progettazione.

Ma questo conflitto lo dovete vivere voi, non vi puõ essere rappresentato in una specie di pantomima in cui io e Gregotti facciamo la scherma con il fioretto, perchè tanto non capireste una parola di quello che diciamo. Mentre invece se voi lo assumete e lo interiorizzate il discorso, da un lato e dall'altro sapendo che i contendenti non hanno mai uno ragione e l'altro torto, ciò che vale è la contesa, tanto non finisce, non c'è un duello che termina. Dunque quello che conta è il duello, perchè tanto più lo storico à insidioso rispetto all'architetto tanto più l'architetto deve rispondere allo storico in maniera furba e insidiosa, ed è cosi che io storico ho contribuito in qualche modo a far si che l'architettura vada avanti. Non sò se vi è chiaro ma è fondamentale affinchè voi possiate capire mè, che da 25 anni penso e pratico questo, ed è una delle poche cose su cui non ho mai cambiato idea.

La storia per architetti significa la storia che vi considera già a priori dei poveri mini sapiens, è come il famoso "Newtonianismo per le dame", cioè Newton spiegato alle donne. Francesco Algarotti scrisse questo libro pensando che le 
donne poverette avessero un cervello un po' più piccolo e non potessero leggere Newton, quindi potevono leggere Newton spiegato alle donne; ecco io mi rifiuto di pensare questo, poi dopodichè se non capite un accidenti allora siamo semplicemente nemici.

Dunque, siccome oggi credo che sia difficile uscire da una situazione di impasse psicologico, anche le mie durezze cercate di capirle, io non ce l 'ho con voi, anzi al contrario, per ragioni mie personali per fare un corso farlo cosi è una fatica molto grande (e chiudiamo qui il discorso), forse per questo non sopporto lassività, però uno degli obbiettivi principali che ho é: trasmet. tere e fecondare. Proviamo quindi a vedere insieme passando attraverso l'esercitazione per arrivare a dei seminari in cui non si seminino solamente buone intenzioni, in cui riusciamo a costruire qualcosa insieme, ricordandovi che gli anni ' 80 oltre ad avervi levato molte cose vi hanno levato la parola: voi non sapete parlare tra di voi come non sapete parlare con mè. Tutto ha congiurato affinchè la situazione dovesse durare in eterno, per fortuna non è accaduto, ma non possiamo assistere a tutto questo: dobbiamo migliorare noi stessi profondamente, perchè non è che c'è qualcuno che lo fa per noi.

Io mi sento un $\mathrm{po}^{\prime}$ provocata dal discorso del prof. Tafuri, e forse questo anche quello che lui vuole come reazione da noi. Io sono venuta a Venezia per trovare questo che non trovavo a Vienna, adesso lei mi dice di cambiare università perchẽ qui fa tutto schifo. Anch'io ho imparato l'italiano per studiare qui, adesso io ho il problema di recuperare in un tempo molto breve tutto quello che lei dice perchè io a Vienna non ho sentito mai niente di Lorenzo Valla. Solo che io adesso non voglio andare via, qui ho vissuto un anno molto intenso e ho capito molte più cose che a casa, forse lei dovrebbe avere più pazienza con noi.

R.

Sa qual'è il problema? Che probabilmente tutti gli studenti di Venezia dovrebbero andare a studiare a Vienna e tutti i viennesi a Venezia.

Distinguiamo un'attimo i piani, Vienna è un simbolo per la cultura contemporanea, uno dei simboli piú alti e tragici perchè era il simbolo dell'unità europea, era l'unico luogo dove sopravviveva l'impero: vale a dire l'unico luogo dove la moltiplicità etnica, la moltiplicità delle lingue (mito di Babele) trova una sedimentazione sotto la figura dell'impero.

Il crollo dell'impero austro-asburgico è stato accompagnato da uno de i momenti piú fertili dell'intelligenza occidentale, in cui si comprendeva che il tema non era quelldi creare lingue, ma come gestire la crisi delle lingue che il crollo dell'impero portava con sè. Non a caso a Vienna si sono concentrati geni della "Secessione", ma principalmente i grandi trasformatori di linguaggi: Adolf Loos, Otto Wagner, Karl Kraus, fino ad Elias Canetti.

Molto abbiamo da imparare dall'equilibrio con cui Vienna guardava, quella che proprio Kraus chiamava: "osservatorio finale dell'apocalisse del mondo"; anche lui vedeva una Vienna un po' come una Venezia, cioè come un luogo che essendo un mito e non essendo reale permette di vedere realmente ció che accade nel mondo. Io penso che lei sia sincera nel dire che a Vienna probabilmente oggi non trova una cultura all'altezza della tradizione che Vienna esprime; io non dico però che qui a Venezia tutto fa schifo, ecc., questa è un'interpretazione un po' ingenua. Io dico invece che qualsiasi discorso unitario dentro una università è diventato impossibile, specie in una facoltà di architettura dove il 
discorso deve essere conflittuale, e la domanda fattami da lei sul restauro è perfetta per dimostrarvi cosa significa "conflittualità", perchè il professore di restauro è tremila volte in conflitto con uno storico, anche se non lo sa. Sarebbe bene che voi interiorizzaste questo conflitto, cioẽ lo razionalo sa. ognuno di voi o in gruppi possibilmente, perchè avete perso la stupendazaste dine di lavorare e studiare discutendo; per esempio puello che stupenda abitufare ẻ di arrivare a questi seminari in sera, la notte, il giorno gia avete discusso in gruppi: 1a sera, la notte, il giorno, quando vi va, ubriacandovi, a letto, quello che vo lete voi. Però la comunicazione tra di voi è importantissima, perchè poi dopo una risposta una discussione rimbalza su un gruppo già formato.

Questo è stato il modo di salvarci l'anima ad esempio (in poche persone) per quell'altro merdaio che era la facoltà di architettura di Roma alla fine degli anni '50: quindi è un'indicazione che vi do; ora peró questi conflitti sono interni a un periodo in cui l'umanità passa una fase di crisi paurosa. Io non credo, non è neanche il mio mestiere dovervi dire qual'è, ma non mi meraviglia se qualcuno non sente questo, perchè allora ha ragione lui: Zelarino! Ma allora se Zelarino vi chiude fuoriuscite da Zelarino, fate come lei e andate via, andate il piü lontano possibile, andate in Scozia.

Vi siete accorti che noi abbiamo un solo sistema politico che è rimasto in piedi che è la democrazia, ma che la democrazia presuppone che tutto il mondo sia democratico, inoltre è un sistema che ha potuto affermarsi in quanto sistema politico per neanche un terzo dell'umanità, presupponendo che gli altri due terzi dovessero essere assoggettati ad essa, se non schiavi.

Dicendo questo dico cose che dovrebbero essere normali, questa è la situazione in cui viviamo e non abbiamo vie d'uscita; quando con Marx che è un grande pensatore del1' '800 (quindi aveva anche una situazione anche un po' diversa) sono stati cercati i sistemi che avevano un'alternanza, quando insomma si sono cercate le alternative, e badate che arrivo a parlare anche del terribile sistema nazista (terribile almeno per mè che sono ebreo), ma persino quella non era un'alternativa per cui l'umanità era cttiva, erano alternative perchè era chiaro che se tutto il mondo diventa democratico moriamo tutti di fame. Ma prima di morire di fame noi che mangiamo due volte e mezza al giorno, difronte all'invasione di milioni e milioni di persone che vorranno mangiare almeno una volta ogni tre giorni noi li uccideremmo. Vi ricordate gli spettacoli televisivi degli albanesi che arrivavano l'estate scorsa, potevamo non accoglierli? Oggi che sappiamo le cifre di disavanzo la ragione ci dice che dovevamo rispedirli a morire di fame, la pietas invece dice che dovevamo accoglierli. Ma quanti di voi avrebbero rinunciato a un golf, alle scarpe, ecc.; quanti di voi riuscirebbero a pagare quello che lo Stato paga per voi? Ve lo ricordo, ognuno di voi costa 18 milioni l'anno (al 1991 ), pensate quind quanto costa allo Stato una lezione. Quando voi vedete le diapositiva sullo schermo e vedete delle buone diapositive, significa che ho mandato in giro per l'Italia qualcuno, e molto spesso solamente le diapositive di una lezione hanno un coso che si aggira sui tre milioni e mezzo di lire, solamente le trenta diapositive molto calcolate. Uno dei miei sistemi per l'università è quello totalmente antidemocratico e antipopolare, ma non me ne importa niente perchẽ è giusto, cioè di partire con delle rette dai sei milioni di lire in su. Pensate che lo studente americano paga 22 milioni come minimo ogni anno, e non protesta sia perche se è molto bravo ha borse di studio che gli permettono di risolvere le sue precarie condizioni (ma allora deve superare con un' alta vo- 
tazione tutti gli esami), oppure per lui è normale fare il lavapiatti e andare all'università, perchè sa che l'università è un privilegio e non istruzione di base. L'università vi rende dei piccoli imprenditori; quando nel 1990 i vostri colleghi di allora occupavano le facoltà contro le leggi sull'autonomia universitaria, perchè dicevano che "il privato non deve entrare dentro l'università", li avrei bruciati tutti sul rogo, perchè voi studiate appunto per fare la piccola impresa. Cos'è un architetto se non è un piccolo imprenditore, for se voi sognate di fare di fare gli usceri in un'ufficio di Stato? Voi sognate di fare gli architetti, vale a dire i piccoli imprenditori. Ma voi dite che: "l'università dev'essere pura...", ma da che cosa? Dov'è che siamo puri? Siamo tutti sporchi, magari abbiamo le ali degli angeli, ma sporche, quindi battono male.

Quindi io non è che dico: "non bisogna venire a Venezia", metto solo in luce i pericoli. Venezia si crede ancora una capitale culturale, non è ancora arrivata a livello di Roma ma ci sta arrivando velocemente: credo che voi vivendo a Venezia possiate confermare quello che dico. Studiare poi architettura a Venezia è pericoloso perchè a Venezia ci sono dei miti architettonici piuttosto che delle sostanze, e comunque Venezia non è il centro del mondo perchè i] mondo non ha centri, quindi va conosciuto tutto. Io cerco di farvi muovere, d incoraggiarvi a lasciare il Veneto troppo caldo e di obbligarvi ad andare nei luoghi dove ci sono le architetture di cui si parla. Ma avete visto, e lo vedrete ancora meglio che uno che voglia capire veramente Alberti almeno in Provenza deve andare, perchè se non vede la Provenza non puõ capire lo choc violentissimo che Alberti deve aver provato: tutta l'architettura antica che si poteva vedere a Roma era a terra (come la vediamo noi oggi, forse un po' meno) quindi si vedeva rovine e si faceva una grande fatica per ricomporla nella propria testa; mentre in Provenza é tutto in piedi, quindi è uno choc per Alberti come per qualsiasi persona che sappia qualcosa di architettura.

Quindi ecco che Venezia dovrebbe diventare un luogo dove noi (in gruppi, insieme a noil pratichiamo delle esperienze fatte fuori, in cui palpiti il mondo, affinchè non si guardi il mondo sotto le pagine del "Venerdi di Repubblica" o quelle dell" "Espresso", perchè quelle non danno il mondo.

Dobbiamo chiederci perō, mentre noi facciano gli architetti perchè gli architetti vanno in carcere, cioè perchè si è arrivati a un livello di corruzione così alto: perchè è intrinseco alle facoltà di architettura, non italiane soltanto ma di tutto il mondo. Quando io vi rinprovero perchè voi non denunciate i vostri docenti, io vi considero correi di questa corruzione profonda dell'universita: voi accettate che poveri assistenti facciano lezione, magari non pagati perchè sono in nero, con docenti che dai primi di novembre (cioè da quando sono iniziati $i$ corsi) non si. sono ancora fatti vedere, per cui questo è normale. Anch'io ho studiato architettura (Doi non ho fatto l'architetto perchè non lo so fare), ma ho imparato che certe volte bisogna far cadere rapidamente la penna, o la matita dal tavolo da disegno per correre in piazza (prendere e srappare selci dai pavimenti delle piazze e lanciarli contro i carabinieri a cavallo: mi sto riferendo proprio al tentativo dittatoriale di Tambroni e alla "battaglia" di S. Paolo, io ho ancora dei segni riportati durante quella battaglia), perchè non si puõ fare architettura sotto Hitler, neanche sotto Tambroni, neanche sotto Andreotti e neanche sotto De Michelis e Craxi. Se voi avete capito in profondo il discorso di Alberti, avrete capito che è proprio questo; ma lo sapete chi ha rubato, e avete contezza di ciò che è oggi 
1'architetto? Perchè ad esempio si è proposto qualche anno fa l'Expó a Vene-
zia? Allora fummo costretti a fare con un manipolo di nimbecillition glia tale che chissá glia tale che chissá come mai c'è andata bene: c'è sempre andato tutto male. doman i arete attivi, andata bene. Questo non ẽ che non vi riguarda perchè un rotte senza talento, per esen con il rischio di essere persone totalmente cor rotte senza talento, per esempio dando troppa importanza all'architettura. Molte cose che gridano la vendetta del cielo sono state fatte da architeti. perchẽ pensavano (arrivo ad un estremo che non è mai esistito) che unchitetti, ger di sterminio nazista ben pianificato, rendeva l'architetto piuto un buon le. atet piutosto noto questo sia niai Albert Speer, il conto, però qualcosa di simile... Non è forse un caso che Speer che has consulente privilegiato di Hitler fosse un architetto. Albert Spandau, Spandau, quando è uscito ha continuato a fare l'architetto, fortunatamente è quale possiamo. Siamo riusciti anche a relizzare un'intervista a Speer, dalla quale possiamo comprendere la banalità del male: cioè il male è banale, non si Carlo come architetti ci si può chiamare Aldo Rosl'architettura 1 'architettura. Se nella testa abbiamo solo l'obbiettivo che dobbiamo fare architettura comunque, allora è proprio l'architetto Ruggine di Alberti: il quale fa l'arco con i diamanti; oppure il grande teatro, ridicolizzando Momus. Questo non fa parte della grande apocalisse del mondo anzi è solamente un piccolo granello, perõ noi abbiamo smesso da tanto tempo di affidarci a quelle che si chiamavano "le grandi narrazzioni": il mondo che va verso questo. verso la libertà, verso ił progresso, ecc. Noi non ci crediamo più a nulla di tutto questo, perõ crediamo che nel piccolissimo che è sotto il nostro occhio, (non dico controllo, ma ... in cui noi abbiamo responsabilità), che in quel piccolissimo come in un qualsiasi racconto Zen, c'é un'istante dove il riscatto dalla melma, dalla schifezza è possibile. Noi tutti quanti insieme, non io, tro questa questi momenti dentro quest'aula (non dentro questa università, dentro quest'aula) e quindi siamo tutti responsabili di avere ogni tanto dei momenti di vita autentica.

Walter Benjamin, il più grande pensatore sull'arte di questo secolo scriveva: "Noi siamo in uno stato di emergenza continua, e a questo stato di emergenza dobbiamo farcela con pochissimo perchè siamo poveri"; ma lui non intendeva poveri di denaro, è la povertà spirituale, ma questa povertà spirituale deve obbligarci ad essere tanto ancora più ostinati a giocarcela in un senso il piũ alto possibile. Quindi quando io vi invito a formare dei gruppi di colloquio è perchè i grandi problemi e i piccoli problemi, l'arco dell'architetto Ruggine e i destini dol. mondo non sono diversi fra di loro se si comprendono le connessioni. I consigli albertiani su come si può essere architetti

scellerati (per forza) ma anche virtuosi, non sono fatti solamente per il ' 400 ; perchè ripeto, noi vivremo oggi in una Venezia ancora più moribonda, moribonda in maniera schifosa, imbellettata, questa vecchia sdentata che sarebbe stata la Venezia dell'Expō. E chi sono gli architetti che avevano ceduto per smania, per "libido edificandi"? Non si chiamavano: Antonio Foscari (professore vostro di $I^{\circ}$ anno di storia dell'architettura), Carlo Aymonino (che è stato il più bravo rettore di questa facoltà prima di lasciare Venezia, e che adesso vuol. tornare), Giorgio Lombardi (vostro docente di urbanistica), cioè non ci sono caduti quasi tutti? Poi c'è un piccolo gruppo che non c'è voluto cadere: Mas- 
simo Cacciari, che ha cercato di creare un fronte; non il P.C.I., quello ha chè da un lato do che noi facessimo la nostra battaglia di opposizione, perchè da un lato doveva fare opposizione e dall'altro doveva partecipare alla te idea di che cosa sarebbe stato il traffico di miliardi internazionali su Venezia, chi avrebbe potuto sorreggere la corruzzione istituzionalizzata di quello che stava per accadere qui proprio due anni fa?

Capite che io mi sento un po' a disagio rispetto a domande che mi sembrano cose che riguardano le "farfalle"?

$V i$ do questo consiglio, provate a specchiare continuamente quello che di specifico noi studiamo con la realtã del mondo, perchè chi vi parla o qualsiasi altro storicio degno di questo nome studia Antelami o Viligelmo (scultori roma nici) perchè un problema urgente di oggi lo sbatte laggiù: non per fuggire, non perchè ha interesse per quello e poi laggiù non c'è; quello è lo storico di serie "B". Il grande storico ha un'urgenza paurosa per il presente, ed è sempre stato cosi. Quando Burckhardt inventa il "rinascimento" lo inventa perchè il suo problena è il risorginento italiano e i suoi amici italiani erano dei federalisti, vale a dire che erano l'anima radicale del risorgimento (non erano C. Benso di Cavour) cioè quelli che avevano fallito.

E' proprio a causa di questo fallimento che Burckhardt idealizza il "rinascimento": cioè lui crea una specie di zona mitica perchè deve sedare, deve suturare una ferita spaventosa che ha nel presente: lui svizzero, quindi personaggio che sa di essere cittadino del mondo e non cittadino cantonale.

Quindi confrontare sempre la situazione di oggi, pregnante, del mondo, della gente che muore tutti i giorni nei più vari modi (e non faccio moralismo, dico soltanto che sono i due terzi dell'umanità) con il vostro mestiere che è assurdamente quello di costruire; ma perchẽ? Per le imprese di Reggio Calabria o per l'abusivismo anche qui nel Veneto, per chi e perchè? Che cosa significa studiare gli antichi monumenti, che cosa ci trasmettono? Perchè dobbiamo salvarli, e potremo salvarli fino alla fine?

Capite che da tutti questi interrogativi non potete aspettarvi risposte: sono i vostri interrogativi, e ve li dovrete portare come tutti ce li portiamo fino a quando chiuderemo gli occhi per sempre e il nostro angelo ci prende la vita. Però il nostro angelo ci chiederà conto di come abbiamo trattato il passato, di come abbiamo avuto pietas (come intendeva Alberti) rispetto a ció che abbiamo scelto, perchè l'abbiamo scelto noi di occuparci di architettura. Quindi fate gruppi (fate quello che vi pare, fate amicizia; difficile? provateci!) in cui si discutono di cose che rimbalzano in una discussione con mè, con noi, ma specialmente tra di voi perchè $i$ seminari migliori sono quelli in cui si incrociano domande e risposte da gruppo a gruppo, per le persone che reggono questo tipo di dialettica. Dopodichè a lezione qualcuno trasmette qual. cosa di molto sedimentato e molto pensato che è poi l'esperienza di una persona, voi invece dovete farvi possibili basi per esperienze individuali. 


\section{Conclusão}

A primeira conclusão concerne a uma ampliação na complexidade da contribuição de Manfredo Tafuri para além dos limites estabelecidos da história da arquitetura. Os laboratórios de pesquisa, o rigor filológico, a crítica à ideologia e seu consequente esmiuçar-se de edifícios e arquitetos são parte da decisão estratégica de um intelectual, mais do que de um profissional dentro de um campo de conhecimento específico.

A subversão do tempo é uma questão que aparece desde a juventude de Tafuri como um nó teórico particular que convidava ao enfrentamento de questões de várias ordens: filosóficas, políticas e estéticas. Entre elas, o tempo não estabelecia uma balança de importância, nem requeria um ordenamento de prioridades. Ao mesmo tempo, cursar arquitetura levou o autor a ver Roma, Veneza e tantas outras cidades como um acervo ruinoso de realizações e desejos.

Durante sua atuação como arquiteto, que durou poucos anos, Tafuri acreditava existir uma via de empenho político através do projeto - no desafio de reinserir as cidades italianas dentro da história, trazer de volta aos edifícios um significado dentro da civilização contemporânea. Sua pesquisas em história da arquitetura, nesse período, tinham duas vertentes: uma na qual o autor já ensaiava a sua verve intelectual conectada ao enfrentamento das questões do humanismo, e uma outra, mais intensiva, de textos e artigos sobre as cidades históricas, sobre os modos pelos quais seria possível estabelecer um diálogo com o passado que não fosse uma literal manobra operativa.

Nesse período, a sua atividade ainda era ligada a correntes bem delimitadas: fazia projeto como nos grupos de projeto romanos ligados ao estudo das megaestruturas e escrevia textos sobre história da arquitetura ainda com muita influência de Benevolo e Zevi - malgrado já possuísse, em obras como “A arquitetura 
moderna no Japão" e "Ludovico Quaroni” uma força de levantamento filológico e aproximação de culturas e questões distintas que ficariam marcados no estilo de sua prosa durante os anos posteriores.

Se a sua obra nutria-se de diversos fermentos da Itália dos anos sessenta, é certo que o tempo como questão filosófica já existia até mesmo na sua atividade de projeto: sua busca não era a de uma arquitetura que se destacaria dos centros históricos, mas que com eles faria uma continuidade não literal. Atento às lições das vanguardas, Tafuri queria trazer as cidades italianas para o presente através de um choc, através das megaestruturas, mas ao mesmo tempo, reconciliar a vida urbana com um tempo que não fosse o da rupturas acrítica. Esse intento o levou ao estudo da obra de Le Corbusier, na qual ele via, na sua obra mais plástica pós 1930, uma atualidade de postulação que conseguia remontar às virtudes imemoriais. "Tempo congelado", conforme o autor se refere à obra do suíço em Chandigarh, já demonstra a sua clareza no modo pelo qual ele via arquitetura como uma subversão da passagem do tempo, como algo destacado do cotidiano, embora próximo dele possa se parecer.

A história, nesses anos, ainda tinha uma importância auxiliar em sua trajetória. Apesar da passagem sobre Le Corbusier ser a semente de toda a sua contribuição como historiador, no grosso de seus textos o tempo passado aparecia ainda como auxiliar no estudo dos modos pelos quais se poderia atuar no presente. A obra que serve como testemunho de uma modificação, ou de uma crise desse ecletismo de atividades do jovem Tafuri, é "A arquitetura do '500 no Maneirismo Europeu”. Nesse livro, Tafuri formaliza a sua busca no passado dos momentos de inflexão, crise e desnorteio que ele via no seu próprio momento histórico. Trata-se do primeiro trabalho em que sugere-se o entremeio histórico, como processo de ampliação de horizontes do pensamento sobre arquitetura. Os motivos do abandono da prática projeto por Tafuri são nebulosos, mas pode-se afirmar com segurança que colaborou nessa decisão uma transformação de seu entendimento das possibilidades de subversão tempo através do trabalho intelectual. Tafuri mergulha em uma crise da qual só sairia após as páginas de "Teorias e história da arquitetura" - uma obra seminal por conter novas características da prosa de Tafuri e, malgrado seja uma virtuose teórica, indica já a pretensão do historiador em colocar a história da arquitetura como atividade intelectual, e portanto participante não de um debate específico - o da arquitetura - 
mas no todo dos fermentos que marcavam a Itália do período. Resolve-se, assim todo o dilema dos anos de formação: tornando-se um intelectual, Tafuri estava livre das idiossincrasias da contingência, do isolamento dos debates de arquitetura e de um compulsório engajamento político ligado ao partidarismo.

Com essa bagagem foi para Veneza, entrando em contato com colegas mais jovens. Se a militância de Cacciari, Dal Co e De Michelis era muito próxima dos dilemas expostos pelo operaismo de Mario Tronti, é fato que Tafuri pertenceu a essa ala pela via da história da arquitetura e dos debates de estética, mais do que nas experiências de leituras de Marx no Porto Marghera, ou outras aproximações entre intelectuais e operários. Seus textos publicados na Revista Contropiano apontam para uma radicalização de diversas opiniões expostas em "Teorias e história" - sobretudo pela premência da crítica à ideologia nas suas leituras das vanguardas. De seus colegas, Tafuri admirava os trabalhos mais teóricos, como os artigos de Cacciari sobre Hegel ou literatura clássica, e os artigos de Dal Co sobre a Bauhaus, retomando Argan sem subscrever a qualquer esperança de "retomada moderna".

Seria, no entanto, demasiado reducionista resumir as transformações do pensamento de Tafuri durante a década de setenta na adoção de uma pesquisa do teor ideológico da arquitetura e do seu subsequente mutismo nas cidades de sua época. "Por uma crítica da ideologia arquitetônica" é um réquiem não só para as leituras das vanguardas como portadores de uma força revolucionária, mas sobretudo para a sua pretensão de insuflar as massas. Não à toa, Tafuri passa a citar os textos de Walter Benjamin que lamentam a perda da experiência no mundo contemporâneo, como "Sobre alguns temas em Baudelaire". É posto em xeque, nesse ensaio de Tafuri, a capacidade de se fazer uma arquitetura cujo protagonista sejam as massas frequentadoras dos edifícios, ou correntes de artistas que queiram postular uma nova era nas cidades. Os textos mais críticos do autor, durante esse período, buscam mostrar como não existe como a arquitetura recuperar, através de qualquer intenção pedagógica, metodológica ou didática, a experiência nas cidades. $\mathrm{O}$ texto talvez mais eloquente nesse sentido seja “A cena como 'cidade virtual”, cuja conclusão apresenta o "Pavilhão Barcelona" de Mies van der Rohe como um espaço que ensina aos frequentadores, através de seus planos puros, uma alienação redundante com a das 
metrópoles, na qual qualquer chance de participação crítica é negada aos seus habitantes.

Mais uma vez em sua trajetória, o presente aparece como rua sem saída. Essa construção da cidade como cena de uma performance mecânica e alienada leva o autor a aproximar arquitetura às tragédias e o arquiteto, como indivíduo, aos personagens trágicos. Nesse sentido, suas pesquisas sobre o humanismo são um trabalho concomitante e intenso na década de setenta, no qual o viés se torna mais distante de uma abordagem que procure estabelecer ligações diretas com a contingência, nos termos em que escreveu "A arquitetura do Maneirismo". $\mathrm{Na}$ aurora de um pensamento centrado no homem, Tafuri encontra dilemas e questões que são mais do que similares àquelas que enfrenta-se no presente: são os mesmos problemas. A tarefa de mediar humanismo e contemporâneo tornou-se supérflua. A arquitetura e as cidades sempre esbateram-se com o desafio de tornar vivos os significados dos edifícios, de ultrapassar as idiossincrasias do seu tempo para construir de fato um discurso sobre as grandes questões que perpassam tempos imemoriais. Não era mais a história das cidades, mas a história da cidade que nunca se apresenta na sua completude e cujas ruas, vias, rios canalizados, igrejas e parques ao redor do globo permitem entrever-se em fragmentos: a cidade longínqua. Desse modo, o entremeio histórico parece sempre improvável em sua prosa, porque ele sempre prescinde de justificativas filológicas ou afinidades de tradição: as correntes e movimentos são todos cotejáveis por fazerem parte de uma única obra.

O protagonismo do arquiteto amplia-se, e suas decisões são ladeadas com as de um personagem trágico. Pela sua dúbia condição de potência e impotência, é uma figura cuja biografia e produção deve ser levada ao máximo de investigação, para que se consiga trazer à tona a parte viva de seus projetos, aspirações e pensamentos sobre as grandes questões e encontrar, a matriz melancólica que reside ao fundo de sua obra. Tafuri esperava de todo arquiteto a mesma espessura de um filósofo.

Essa visão, que se consolidou entre 1978 e 1981, é legível em diversas grandes decisões do autor: na preferência em lecionar somente sobre o humanismo e barroco, a sua inclinação maior por tecer obras e artigos monográficos.

A ideia de protagonismo não se limitava aos arquitetos. Em certos ensaios, as próprias cidades deixam de ser vistas como cena e passam a ser capazes de performar o 
drama que Tafuri articulava. Se nos primeiros anos do IUAV ele se lançou, junto com seus colegas, ao estudo de metrópoles que pulsavam o máximo de progressismo diante daquele período marcado pela cortina de ferro e pelo embate entre dois mundos, com o tempo sua prosa torna-se menos interessada na parte urbanística e foca-se nas mitologias fundacionais, nos significados mais misteriosos que marcam as capitais. "A montanha desencantada" é o primeiro testemunho dessa interpretação sobre a cidade de Nova York, que seria radicalizada no artigo "As cinzas de Jefferson”, no qual a cidade e seus arranha-céus é, pela sua melancólica e solitária floresta de apartamentos elevados às alturas, comparada com Veneza e seus canais fantasmagóricos.

Apesar de ter escrito sobre Nova York, Roma e outras, Veneza é a grande cidade protagonista de Tafuri. As pesquisas sobre a Serenissima no '500 mostra a sua condição de álamo entre o Ocidente e o Oriente. Essa dicotomia, ainda que não amplamente estudada por Tafuri, sempre lhe serviu de álibi para que o entremeio histórico pudesse ser feito em outra escala: a do entremeio entre realidade e mito. $\mathrm{O}$ Oriente aparece sempre como uma 'imagem do outro', uma figura mágica que serve de mediação entre a contingência e os tempos imemoriais, entre a cidade construída e a longínqua. Em Veneza, essa imagem aparece na iconografia do '500, nas imagens pagãs presente tanto na pintura de Giorgione e Tintoretto, nos símbolos do Tricipitium em residências venezianas e em textos como a Hypnerotomachia Poliphilii, de Francesco Colonna.

Nessa história de Tafuri com o tempo, o que se sobressaía era sempre uma construção histórica que buscava trazer ao presente não um método, uma postulação ou preceptiva, mas o discurso que as cidades e arquitetos deixaram como legado em um debate longo, perdido e em andamento. A história da arquitetura, do modo como Tafuri a concebeu, depende dessa noção temporal que cristaliza todos os períodos em um só, e decanta as mais profundas questões ditas pelas pedras e tijolos que fizeram as civilizações.

No que concerne a hipótese da tese, de que a complexidade da historiografia do autor romano reside no seu entremeio de tempos, é possível encontrar muito material que a corrobora, desde sua juventude até os seus últimos dias. A noção temporal de Tafuri permite abrir novas perspectivas de pesquisa pela ampliação do 
fulcro de interpretação da obra desse intelectual, menos pautada por uma disciplina própria, e mais inserível em um escopo maior de sua contribuição.

O tempo de Tafuri lança luz a uma parte do autor que ficou menos em evidência desde a sua morte, e que ajuda a compreender como o autor via o engajamento da arquitetura nas grandes questões. Tendo vivido em décadas nas quais a atividade sofreu um alijamento de sua capacidade de intervenção no real, entrevando-se em debates herméticos e resguardando-se, cada vez mais, em um espectro específico de atuação, Tafuri agiu na direção oposta. Quem leia sua profissionalização da história da arquitetura como a fundação de uma área especial nas ciências humanas estará incutindo em uma leitura desinformada de seu trabalho. $\mathrm{O}$ objetivo, ao criar essa autonomia de investigação, era de criar os meios pelos quais ela seria colocada na ponta de lança dos debates sobre o presente.

Portanto, para leituras posteriores, é estratégico que se façam estudos que não procurem dar conta de esclarecer as partes obscuras da obra de Tafuri mas, ao contrário, levá-las ao âmago da angústia que tomava o professor, e a partir delas tecer uma nova história, não nos termos do pagamento de uma dívida com o seu legado, mas como uma busca contínua pelos entremeios mais improváveis e interessantes.

Mesmo a história em si, como área acadêmica, interessava menos a Tafuri do que aquilo que adviria de seu aprofundamento: o brilho de uma arquitetura que pode, num átimo, levar-nos aos portões de uma cidade na qual o tempo não seja aquele das máquinas, do capital, da natureza ou dos deuses, que insistem em subjugar-nos através dos séculos. 


\section{Bibliografia}

Corpus da pesquisa:

- TAFURI, Manfredo. Le forme del tempo: Venezia e la modernità. Veneza: IUAV, 1994.

- TAFURI, Manfredo. “Machine et memoir: La città nell'opera di Le Corbusier”. In: Nuova Corrente, n. 87, 1982, pp. 3-32.

- TAFURI, Manfredo. Projeto e utopia, arquitetura e desenvolvimento do capitalismo. Lisboa: Presença, sd.

- TAFURI, Manfredo. Teorie e storia dell'architettura. Tradução para o português Teorias e bistória da arquitetura. Lisboa/ São Paulo: Presença/Martins Fontes, 1979.

Bibliografia complementar do autor:

- ASOR ROSA et al. Socialismo, ciudad y arquitectura: la aportación de los arquitectos europeos. Madrid: Alberto Corazón, 1973.

- CIUCCI, Giorgio; DAL CO, Francesco; MANIERI ELIA, Mario; TAFURI, Manfredo. La città americana dalla guerra civile al Nerw Deal. Roma: Laterza, 1973.

- DAL CO, Francesco e TAFURI, Manfredo. Arquitetura contemporânea. Milão: Electa, 1976.

- FOSCARI, Antonio; TAFURI, Manfredo. L'armonia e i conflitti: la chiesa di San Francesco della Vigna nella Venezia del cinquecento. Turim: Einaudi, 1983.

- PICCINATO, Giorgio; QUILICI, Vieri; TAFURI, Manfredo. "La città territorio: verso una nuova dimensione”. In: Casabella Continuità, n. 270, 1962, pp. 16-25.

- SALERNO, Luigi; SPEZZAFERRO, Luigi; TAFURI, Manfredo. Via Giulia: una utopia urbanistica del cinquecento. Roma: Staderini, 1975.

- SQUARZINA, Luigi; TAFURI, Manfredo. Teatri e scenografie. Milão: Touring Club, 1976. 
- TAFURI, Manfredo. "L’Archeologia del presente". In: Il disegno dell'architettura. Incontri di lavoro, Università di Parma, Centro di studi e archivio della comunicazione: Parma, 1980, pp. 22-29.

- TAFURI, Manfredo. L'Architettura moderna in Giappone. Bolonha: Cappelli, 1964.

- TAFURI, Manfredo. L'architettura moderna alla luce dei problemi attuali. Facoltà di Architettura dell'Università di Palermo, Corso di composizione architettonica II: Palermo, 1966-67.

- TAFURI, Manfredo. L'Architettura del Manierismo nel Cinquecento europeo. Roma: Officina, 1966.

- TAFURI, Manfredo. L'Architettura dell'umanesimo. Bari: Laterza, 1969.

- TAFURI, Manfredo. La esfera y el labirinto. Vanguardias y arquitectura de Piranesi a los años setenta. Barcelona: Editorial Gustavo Gili, 1984.

- TAFURI, Manfredo. "The dialectics of the Avant-Garde: Piranesi and Eisenstein". In: Oppositions, n. 11, 1977, pp. 72-80.

- TAFURI, Manfredo. "L’ephemere est eternel. Aldo Rossi a Venezia”. In: Domus, n. 602, 1980, pp. 7-11.

- TAFURI, Manfredo. "Ernst May e l'urbanistica razionalista". In: Comunità, Out. 1964, pp. 66-80.

- $\quad$ TAFURI, Manfredo. “European Graffiti': five x five = twenty-five. In: Oppositions, n. 5, 1975, pp. 35-74.

- $\quad$ TAFURI, Manfredo. Five Architects N.Y. Roma: Officina, 1981.

- TAFURI, Manfredo. "Francesco Borromini e la crisi dell'universo umanistico", Corso di storia dell'architettura 2A: Trascrizione delle lezione tenute dal prof. Manfredo Tafuri nel corso dell'anno accademico 1978/79, a cura degli studenti iscritti al corso”, IUAV, 1979.

- TAFURI, Manfredo. "La 'Grande Vienna': dalla formazione del mito asburgico alla crisi dell'austromarxismo." Corso di storia dell'architettura 2A: Trascrizione delle lezione tenute dal prof. Manfredo Tafuri nel corso dell'anno accademico 1977/78, a cura degli studenti iscritti al corso”, IUAV, 1978.

- TAFURI, Manfredo. "Lavoro intellettuale e sviluppo capitalistico". In: Contropiano, n. 2, 1970, pp. 241-281.

- TAFURI, Manfredo. Ludovico Quaroni e lo sviluppo dell'architettura moderna in Italia. Milão: Edizioni di Communità, 1964. 
- TAFURI, Manfredo. "Umanesimo e l'architettura: Leon Battista Alberti (1404-1472), Corso di Storia dell'Architettura 2A (1992-93), Biblioteca do “Dipartimento di Storia dell'Architettura", IUAV, 1993.

- CACCIARI, Massimo; DAL CO, Francesco; TAFURI, Manfredo. "Il mito di Venezia”. In: Rassegna, Jun. 1985, pp. 7-9.

- TAFURI, Manfredo. “La 'nuova Costantinopoli'. La rappresentazione della 'renovatio' nella Venezia dell'Umanesimo (1450-1509)”. In: Rassegna, n. 9, Mar. 1982, pp. 25-38.

- TAFURI, Manfredo. "Per una critica dell'ideologia architettonica". In: Contropiano, n.1, 1969, pp. 31-79.

- TAFURI, Manfredo. “La prima strada di Roma moderna: via Nazionale”, In: Urbanistica, n.27. 1959, pp. 95-109.

- TAFURI, Manfredo. "Il progetto storico". In: Casabella, n. 429, 1977, pp. 11-18.

- TAFURI, Manfredo. "La nuova dimensione urbana e la funzione dell'utopia”. In: L'Architettura Cronache e Storia, v. 124, 1966, pp. 680-683.

- TAFURI, Manfredo. Ricerca del Rinascimento: principi, città, architetti. Turim: Einaudi, 1992.

- TAFURI, Manfredo. "Seminario", transcrição de aula de 23 de janeiro de 1993.

- TAFURI, Manfredo. "Socialdemocrazia e città nella Repubblica di Weimar". In: Contropiano, n. 1, 1971, pp. 207-223.

- TAFURI, Manfredo. Storia dell'architettura italiana, 1944-1985. Turim: Einaudi, 2002.

- $\quad$ TAFURI, Manfredo. “Storicità di Louis Kahn”. In: Comunità, Fev. 1964, pp. 38-49.

- TAFURI, Manfredo. Venezia e il Rinascimento: religione, scienza, architettura, Turim: Einaudi, 1985.

- $\quad$ TAFURI, Manfredo e TEODORI, Massimo. "Lettere di studenti”. In: Casabella, n. 241, 1960, p.56.

Bibliografia geral:

- $\quad$ ARCHITECTURE NEW YORK edição especial "Being Manfredo Tafuri”, 25 e 26, 2000.

- AGAMBEN, Giorgio. Infância e história: destruição da experiência e origem da história. Belo Horizonte: UFMG, 2008.

- AGAMBEN, Giorgio. "Da utilidade e dos inconvenientes de viver entre espectros". In: Serrote, n. 6, 2010, pp. 65-69.

- $\quad$ ARANTES, Paulo Eduardo. Hegel, a ordem do tempo. São Paulo: Hucitec, 1981. 
- ARGAN, Giulio Carlo. Progetto e destino. Milão: Il Sagiattore, 1977.

- ARGAN, Giulio Carlo. Salvación y caída del arte moderno. Buenos Aires: Nueva Visión, 1966.

- ARGAN, Giulio Carlo. Walter Gropius y el Bauhaus. Nueva Visión: Buenos Aires, 1957.

- ASOR ROSA, Alberto. Socialismo, ciudad y arquitectura. Madrid: Corazon, 1973.

- ASOR ROSA, Alberto e CACCIARI, Massimo. "Primo Bilancio". In: Contropiano, n.2, 1968, pp. 237-244.

- “Associazione studenti e architetti”. In: L'Architettura cronache e storia, n. 45, 1959, p. 211.

- AYMONINO, Carlo. Orígenes y desarrollo de la ciudad moderna. Barcelona: Gustavo Gili, 1972.

- BARTHES, Roland. Mitologias. Rio de Janeiro: Difel, 2007.

- BEDON, Anna; BELTRAMINI, Guido; BURNS, Howard. 'Questo': disegni e studi di Manfredo Tafuri per la ricostruzione di edifici e contesti urbani rinascimentali. Vicenza: CISA, 1995.

- BENJAMIN, Walter. Ensaios reunidos: escritos sobre Goethe. São Paulo: Editora 34, 2009.

- BENJAMIN, Walter. Textos escolbidos de Walter Benjamin, Max Horkheimer, Theodor W. Adorno e Jürgen Habermas. São Paulo: Abril, 1983.

- BENJAMIN, Walter. Origem do drama trágico alemão. Lisboa: Relógio D’Água, 2000.

- BENJAMIN, Walter. Magia e técnica, arte e política. São Paulo: Brasiliense, 1996.

- BIALAKOWSKY, Guillermo. "Tiempo y representación. La crítica impolítica italiana al pensamiento de Carl Schmitt" In: Instantes y azares: Escrituras Nietzscheanas. n.9, 2011, pp. 289-300.

- BIRAGHI, Marco. Progetto di crisi: Manfredo Tafuri e l'architettura contemporanea. Milão: Marinotti Edittore, 2005.

- BORRADORI, Giovanna. "Weak thought' and Postmodernism: The Italian Departure from Deconstruction”, In: Social Text, n. 19, 1987-1988, pp. 39-49.

- BROWN, Allison. "Lucretius and Epicureans in the Social and Political Context of Renaissance Florence", In: I Tatti Studies in the Italian Renaissance. v.9, 2001, pp. 11-62.

- $\quad$ BUTOR, Michel. La modification. Paris: Les Editions de Minuit, 2012.

- CACCIARI, Massimo. L'angelo necessario. Milão: Adelphi, 1986.

- CACCIARI, Massimo. L'arcipelago. Milão: Adelphi, 1997.

- CACCIARI, Massimo. Dellinizio. Milão: Adelphi, 2001.

- CACCIARI, Massimo. “Obituary”. In: AULENTI, Gae. L'Architecture D’ajourd’hui, n²92, 1994, p. 25. 
- CACCIARI, Massimo. "Di alcuni motivi in Walter Benjamin (Da 'Ursprung des deutrschen Trauerspiels' a 'Der Autor als Produzent'. In: Nuova corrente, n. 66, 1975, pp. 220 e 243.

- CACCIARI, Massimo. "Idea di Venezia”. In: Casabella, n.557, v.53, 1989, pp. 42-58.

- CACCIARI, Massimo. Krisis, ensayo sobre la crisis del pensamiento negativo de Nietzsche a Wittgenstein. Cidade do México: Siglo Veintiuno editores, 1982.

- CACCIARI, Massimo. Metropolis, saggi sulla grande citta di Sombardi, Endell, Scheffler e Simmel. Roma: Oe, 1973.

- CACCIARI, Massimo. “Mies's classics”. In: RES, n.16, 1988, pp. 9-16.

- CACCIARI, Massimo. "Sulla genesi del pensiero negativo”. In: Contropiano, n.1, 1969, pp. 131-200.

- CACCIARI, Massimo. "Transformación del estado y proyecto político". In: Cuadernos políticos, n. 25, 1980, pp. 7-28.

- CACCIARI, Massimo. "Utopia e socialismo". In: Contropiano, n. 3, 1970, pp. 563-586.

- CASABELLA edição especial "Il Proggetto storico di Manfredo Tafuri”, 619-620, Janeiro, 1995.

- CAZALÉ BÉRARD et. al. La mer dans la culture italienne. Paris: Presses universitaires de Paris Ouest, 2009.

- CASERO, Jorge Leon. “Aion e historiografía en la obra de Manfredo Tafuri”. In: Revista Internacional de Filosofia, n. 56, 2012, pp. 173-193.

- ÇELIK, Zeynep. “Le Corbusier, Orientalism, Colonialism”. In: Assemblage, n. 17, 1994, pp. 58-77.

- CIUCCI, Giorgio; DAL CO, Francesco. Architettura italiana del '900. Milão: Electa, 1993.

- "La Città territorio: Un esperimento didattico sul Centro Direzionale di Centocelle in Roma.” Roma: Leonardo Da Vinci Editrice, 1964.

- COHEN, Jean-Louis. "La coupure entre architectes et intellectuals, ou les enseignements de l'italophilie". In: In Extenso, v.1, 1984, p. 214-215.

- COLOMINA, Beatriz. "Le Corbusier and Photography". In: Assemblage, n. 4, 1987, pp. 6-23.

- “Concorso per il centro direzionale di Torino”. In: Casabella, n. 278, 1963, pp. 2-55.

- COSENZA, Luigi. "Per un dibattito costruttivo”. In: Casabella, n.230, 1959, pp. 2-5.

- DAL CO, Francesco. "Architettura e piano in Unione Sovietica: stalinismo e il 'destino dell'avanguardia"'. In: Contropiano, n. 3, 1969, pp. 527-575.

- DAL CO, Francesco. Kevin Roche. Milão: Electa, 1985. 
- DAL CO, Francesco. "Note per la critica dell'ideologia dell'architettura moderna: da Weimar a Dessau". In: Contropiano, n. 01, 1968, pp. 163-170.

- DAL CO, Francesco. Teorie del moderno: architettura, Germania, 1880-1920. Roma/ Bari: Laterza, 1982.

- DAY, Gail. Dialectical passions: negation in postwar art theory. New York: Columbia University Press, 2011.

- DAY, Gail. "Strategies in the Metropolitan Merz: Manfredo Tafuri and the Italian Workerism”. In: Radical Philosophy, n. 133, 2005, pp. 26-38.

- DELLA VOLPE, Galvano. Critica del gusto. Milão: Feltrinelli, 1966.

- DELLA VOLPE, Galvano. Critica dell'ideologia contemporanea: saggi di teoria dialettica. Roma: Editori Riuniti, 1980.

- DELLA VOLPE, Galvano. Logica come scienza storica. Roma: Editori Riuniti, 1969.

- DORFLES, Gillo. "New Currents in Italian Aesthetics". In: The Journal of Aesthetics and Art Criticism, v.12, n. 2, 1953, pp. 184-196.

- DOORDAN, Dennis P. "Changing agendas: architecture and politics in contemporary Italy". In: Assemblage, n. 8, 1989, pp. 60-77.

- DUNSTER, David. "Tafuri's architecture and utopia”. In: $A D$, n. 47, 1977, pp. 204212.

- FISHMAN, Robert. "Utopia and its discontents". In: The Journal of the Society of Architectural Historians, v. 39, 1980, pp. 153-155.

- FISTETTI, Francesco. "La crise du marxisme en Italie: 1980 - 2005”. In: Cités, v.4, 2007, pp. 159-183

- GAMBINO, Susanna. "Alberti lettore di Lucrezio. Motivi lucreziani nel Theogenius". In: Albertiana, n. IV, 2001, pp.69-84.

- GARIN, Eugenio. Medioevo e Rinascimento: studi e ricerche. Bari: Laterza, 2005.

- GÓMEZ, Patricio Peñalver. “Decisiones. Schmitt, Heidegger, Barth”. In: Daimon, Revista de Filosofia, n.13, 1996, p. 141-166.

- HEIDEGGER, Martin. Os conceitos fundamentais da metafísica. Rio de Janeiro: Gen e Forense, 2011.

- HEIDEGGER, Martin. "Identidade e diferença”. In: Conferências e escritos filosóficos. São Paulo: Abril Cultural, 1983.

- HEIDEGGER, Martin. A origem da obra de arte. Lisboa: Editora 70, 2000.

- HEIDEGGER, Martin. Ensaios e conferências. Petrópolis: Vozes, 2002.

- HEIDEGGER, Martin. Ser e tempo. Petrópolis: Editora Vozes, 2006. 
- HOEKSTRA, Titia. "Building vs. Bildung. Manfredo Tafuri and the construction of a historical discipline”. Groningen: Tese de doutorado. Rijksuniversiteit Groningen, 2005.

- KAPLAN, Jim. "Introdution to the revolutionary left in Italy". In: Radical America, n.07, 1972, publicado no site "http://libcom.org/library/introduction-revolutionary-left-italyjim-kaplan”, acesso em 29/11/2012, 08:32.

- KEYVANIAN, Carla. Manfredo Tafuri's notion of history and its methodological sources: From Walter Benjamin to Roland Barthes. Master of science in architecture studies, Department of Architecture, Massachussets Institute of Technology, Fev. 1992

- KUBLER, George. The shape of time: remarks on the history of things. New Haven and London: Yale University Press, 1962.

- JEANNERET, Charles Edouard. Por uma arquitetura. São Paulo: Perspectiva, 2000.

- JEANNERET, Charles Edouard. Precisões sobre um estado presente da arquitetura e do urbanismo. São Paulo: Cosac e Naify, 2004.

- LEACH, Andrew. Choosing history: A study of Manfredo Tafuri's theorisation of architectural history and architectural history research. Ghent.Tese de Doutorado, 2005.

- LEACH, Andrew. "Francesco Borromini and the Crisis of the Humanist Universe, or Manfredo Tafuri on the baroque origins of modern architecture", In: The Journal of Architecture, n. 15:13, pp. 301-335.

- $\quad$ LIPSTADT, Hélène e MENDELSOHN, Harvey. "Philosophy, History and Autobiography: Manfredo Tafuri and the unsurpassed lesson of Le Corbusier”. In: Assemblage, 22, 1994, pp. 58 a 103.

- LLORENS, Thomas, "Manfredo Tafuri: Neo Avant-Garde and History”, In: Architectural Design, v. 51, 1981, pp. 83-95.

- MALFAI, Miriam. Il sorpasso: gli straordinari anni del miracolo economico. Milão: Mondadori, 1997.

- MANDARINI, Matteo. "Beyond nihilism: notes towards a critique of leftheideggerianism in italian philosophy of the 1970s". In: Cosmos and History: The Journal of Natural and Social Philosophy, v. 5, 2009, pp. 37-56.

- DI MARINO, Orlando (org.). Manfredo Tafuri: oltre la storia. Nápole: CLEAN, 2009.

- MARRAMAO, Giacomo. Minima temporalia: tempo, spazio, esperienza. Milão: Il saggiatore, 1990.

- MARRAMAO, Giacomo. Poder e secularização: as categorias do tempo. São Paulo: Unesp, 1995.

- MURATORI, Saverio. Studi per una storia operante. Storia urbana di Venezia. Roma: Istituto poligrafico dello stato, 1959. 
- OCKMAN, Joan (org.). Architecture, criticism, ideology. New Jersey: Princeton Architectural Press, 1985.

- PACI, Enzo.Tempo e relazione. Milão: Il Saggiatore, 1965.

- PEREIRA, Wilcon J. (org). Della Volpe. São Paulo: Ática, 1979.

- PRIMAVESI, Patrick. "The performance of translation: Benjamin and Brecht on the loss of small details". In: TDR, v. 43, n. 4, "German Brecht, European Readings", inverno de 1999, pp. 53-59.

- "Progetti di architetti romani”. In: Casabella, n. 289, 1964, pp.2-49.

- QUILICI, Vieri. L'architettura del costruttivismo. Bari: Laterza, 1969.

- RELLA, Franco. Il silenzio e le parole: il pensiero nel tempo della crisi. Milão: Feltrinelli, 1981.

- ROGERS, Ernesto Nathan. "Russia, contenuto e forma”. In: Casabella, n. 262, 1962, p.3.

- ROSA, Aberto Asor. Scrittori e popolo. Roma: Samonà e Savelli, 1965.

- ROSA, Federico. Progetto e critica dellurbanistica moderna: i primi anni di attività di Manfredo Tafuri, 1959-1968. Tesi di laurea, Relatore Bernardo Secchi, Università IUAV di Venezia, Facoltà di architettura, Corso di laurea in architettura, 2003.

- $\quad$ SAID, Edward. Orientalism. New York: Vintage, 1979.

- SASSATELLI, Monica. "Everything changes and nothing changes: Change, culture and identity in contemporary Italian social theory”. In: DELANTY, Gerard (org.). Handbook of Contemporary European Social Theory. London: Routledge, 2005, pp. 95-107.

- SERRES, Michel. O nascimento da física no texto de Lucrécio. São Paulo e São Carlos: Editora da Unesp e Editora da Ufscar, 2003.

- SHERER, Daniel. "Un coloquio inquietante. Manfredo Tafuri e la critica operativa, 1968 - 1980". In: La critica operativa e l'architettura. Milão: Unicopli, 2002, pp. 108-120.

- SHERER, Daniel, "Proggetto e ricerca. Manfredo Tafuri come storico e come critico". In: Zodiac , n.15, 1996, pp. 32-51.

- "Si accordano su un punto: è meglio il meretricio". In: L'Architettura cronache e storia, n. 57, 1960, pp. 148-149.

- SIMMEL, Georg. "A metrópole e a vida mental”. In: VELHO, Otávio Guilherme. O fenômeno urbano. Rio de Janeiro: Zahar editores, 1967.

- SONTAG, Susan. Sob o signo de Saturno. Porto Alegre e São Paulo: L\&PM, 1986.

- SPINI, Aldo. "The new left in Italy". In: Journal of contemporary history, v. 7, n. 1/2, 1972, pp. 51-71. 
- TAYLOR, Brian Brace; TEYSSOT, Georges. "Actualité de Manfredo Tafuri”. In: Architecture d'aujourd'hui, Abril, 1977.

- TOURNIKIOTIS, Panayotis. Historiography of modern architecture. Cambridge and London: MIT Press, 1999.

- VIDLER, Anthony. History of the immediate present: Inventing Architectural Modernism. Cambridge: The MIT Press, 2008.

- ZEVI, Bruno. Architettura e storiografia. Milão: Tamburini, 1950

- ZEVI, Bruno. Saber ver a arquitetura. São Paulo: Martins Fontes, 2000.

As obras citadas foram todas utilizadas, diretamente ou indiretamente, na confecção dos argumentos da tese. Para o quadro completo das obras disponíveis de Tafuri, é referencial o volume "Manfredo Tafuri, oltre la storia", organizado por Orlando di Marino, supracitado.

Todas as citações de edições em língua estrangeira foram traduzidas pelo autor. 


\section{Ilustrações}

1. Le Corbusier, Plan Obus, Argel, 1933, In: Boesinger, Willy (ed.) "Le Corbusier et Pierro Jeanneret -Oeuvre Complète de 1929 - 1934. Zurique: “Les éditions d'architecture Artemis”, 1964.

2. Le Corbusier, Main Ouverte, Chandigarh, In: Boesinger, Willy (ed.) "Le Corbusier - Les dernières oeuvres - volume 8 des Oeuvres complètes" Zurique: "Les Editions d'Architecture Artemis", 1970.

3. Le Corbusier, Main Ouverte sobre a Barragem de Bhakra, In: Boesinger, Willy (ed.) "Le Corbusier - Les dernières oeuvres - volume 8 des Oeuvres complètes" Zurique: “Les Editions d'Architecture Artemis”, 1970.

4. Batalha na Porta San Paolo, Roma, 1943, In: Caporilli, Pietro, "Trent'anni di vita italiana, 1915-1945, Roma: Nastasi, 1967.

5. Ocupação estudantil na Faculdade Valle Giulia, Roma, 1968, Domínio público.

6. Exercícios de estudantes de Saverio Muratori, circa 1960, In: "L’Architettura Cronache e Storia”, n. 57, 1960.

7. Ludovico Quaroni et. alt. Centro direcional de Turim, Proposta vencedora, 1963, In: "Casabella" n. 279, 1963.

8. Studio AUA, Centro direcional de Turim, Projeto destacado, 1963, In: “Casabella" n. 279, 1963.

9. Studio AUA, Concurso para o Hospital de Veneza, 1964, In: “Casabella” n. 289, 1964.

10. Studio AUA, Concurso para o Hospital de Veneza, 1964, In: "Casabella” n. 289, 1964.

11. Studio AUA, Concurso para o Hospital de Veneza, 1964, In: "Casabella” n. 289, 1964. 
12. Le Corbusier, Desenhos para o hospital de Veneza, 1965, In: Boesinger, Willy (ed.) "Le Corbusier - Les dernières oeuvres - volume 8 des Oeuvres complètes" Zurique: "Les Editions d'Architecture Artemis”, 1970.

13. Studio AUA, Edifício habitacional em Latina, 1964, In: "Casabella” n. 289, 1964.

14. Manfredo Tafuri, Desenhos de estudo da Igreja San Giovanni dei Fiorentini, proposta de Antonio Sangallo, o Jovem, In: BEDON, Anna, BELTRAMINI, Guido, BURNS, Howard, “'Questo': disegni e studi di Manfredo Tafuri per la ricostruzione di edifici e contesti urbani rinascimentali”, Vicenza: CISA, 1995

15. Oskar Schlemmer, Croqui para o ballet triádico, In: Schlemmer, Tut (ed.), "The Letters and Diaries of Oskar Schlemmer", Middletown: Wesleyan University Press, 1972.

16. Le Corbusier, Coberture De Beistegui, Paris, 1929, In: Boesinger, Willy (ed.) "Le Corbusier et Pierro Jeanneret -Oeuvre Complète de 1929 1934. Zurique: "Les éditions d'architecture Artemis”, 1964.

17. Eliel Saarinen, Concurso para Chicago Tribune Tower, Chicago, Segundo lugar, 1922, In: Albert, Chris-Janer, “Eliel Saarinen”, Chicago: University of Chicago, 1948.

18. Benedetto Antelami, Portal sul do Batistério de Parma, 1196, Wikipedia Commons.

19. Ilustração do Tricipitium em "Hypnerotomachia Poliphili", de Francesco Colonna, 1499, fac-símile: Milão: Adelphi, 2004.

20. Giorgione, Allegoria della prudenza, 1570, National Gallery, Londres.

21. Aldo Rossi, Teatro del mondo, Veneza, 1979, Gianni Braghieri, In: "Aldo Rossi Architect”, Londres: Academic editions, 1994.

22. Santiago Calatrava, Quarta ponte sobre o Canal Grande, Veneza, 2008, In: “Casabella”, n. 769, 2008. 